\author{
UNIVERSIDADE DE SÃO PAULO \\ ESCOLA DE ENGENHARIA DE SÃO CARLOS \\ PROGRAMA DE PÓS-GRADUAÇÃO EM ENGENHARIA HIDRÁULICA E \\ SANEAMENTO
}

LEONARDO HENRIQUE SOARES DAMASCENO

\title{
DEGRADAÇÃO DO ALDICARBE EM BIORREATOR ANAERÓBIO HORIZONTAL DE LEITO FIXO
}





\section{DEGRADAÇÃO DO ALDICARBE EM BIORREATOR ANAERÓBIO HORIZONTAL DE LEITO FIXO}

Tese apresentada à Escola de Engenharia de São Carlos, da Universidade de São Paulo, como parte dos requisitos para obtenção do título de Doutor em Engenharia Hidráulica e Saneamento

Orientador: Prof. Dr. Marcelo Zaiat

São Carlos

2008 
AUTORIZO A REPRODUÇÃO E DIVULGAÇÃO TOTAL OU PARCIAL DESTE TRABALHO, POR QUALQUER MEIO CONVENCIONAL OU ELETRÔNICO, PARA FINS DE ESTUDO E PESQUISA, DESDE QUE CITADA A FONTE.

Ficha catalográfica preparada pela Seção de Tratamento da Informação do Serviço de Biblioteca - EESC/USP

Damasceno, Leonardo Henrique Soares Damasceno Degradação do aldicarbe em biorreator anaeróbio horizontal de leito fixo / Leonardo Henrique Soares Damasceno; orientador Marcelo Zaiat. -- São Carlos, 2008 .

Tese (Doutorado - Programa de Pós-Graduação e Área de Concentração em Hidráulica e Saneamento) -- Escola de Engenharia de São Carlos da Universidade de São Paulo, 2008 .

1. Biorremediação. 2. Carbamato. 3. HPLC.

4. Pesticida. 5. RAHLF. 6. Reator biológico. 7. Título. 
Candidato: Engenheiro LEONARDO HENRIQUE SOARES DAMASCENO

Tese defendida e julgada em 28/11/2008 perante a Comissão Julgadora:

Pant

Prof. Associado MARCELO ZAIAT (Orientador)

(Escola de Engehharia de \$ão Carlos/USP)

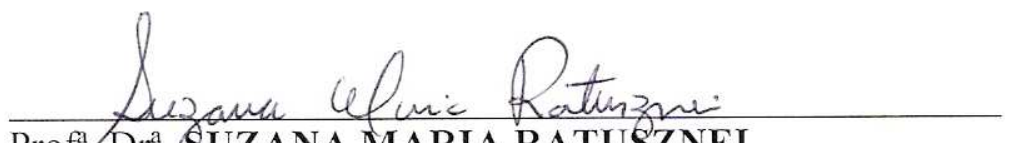

Prof ${ }^{a}$ Dr ${ }^{\mathrm{a}}$. QUZANA MARIA RATUSZNEI

(Escola de Engenharia de Mauá/EEM)

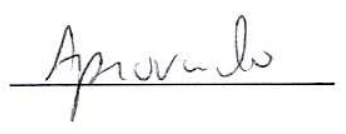

Aprovado

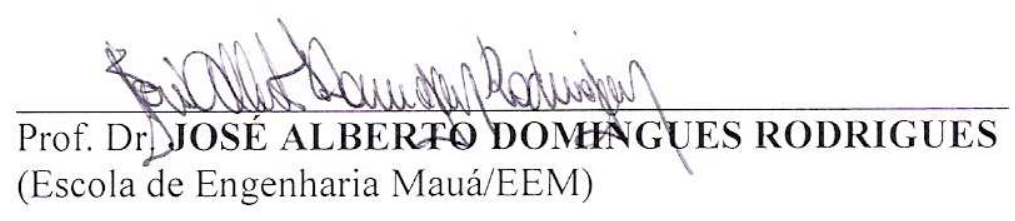

APRONADO

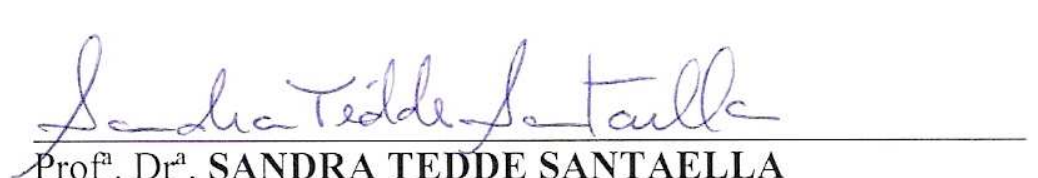

Prof ${ }^{\mathrm{a}}$. Dr ${ }^{\mathrm{a}}$. SANDRA TEDDE SANTAELLA

(Universidade Federal do Ceará/UFC)

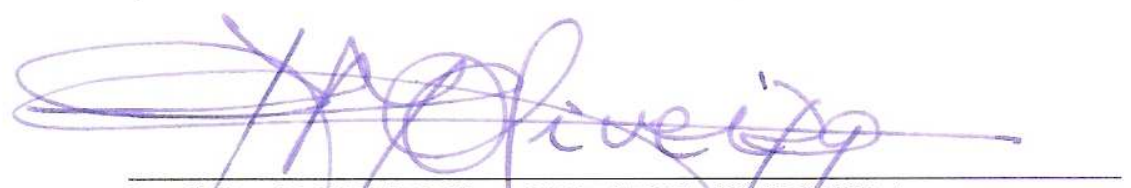

Prof.Dr. ROBERTO ALVES DE OLIVEIRA

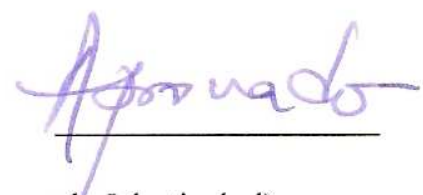

(Universidade Estadual Paulista "Júlio de Mesquita Filho" UNESP/Campus de Jaboticabal)
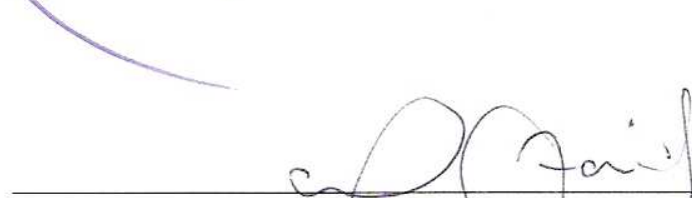

Prof. Associado MARCELO ZAIAT

Coordenador do Prograłaade Pós-Graduação em

Engenharia (Hidráulica e Saneamento)

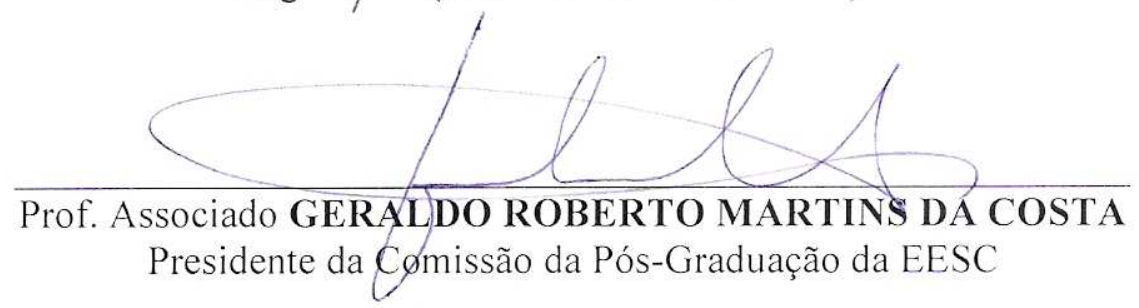



"Todos nós nascemos com potencialidade para nos tornarmos diferentes pessoas, mas o que nos tornamos realmente depende das condições sob as quais nos desenvolvemos. Essas condições, além do mais, são freqüentemente resultado de nossa própria escolha." René Jules Dubos

Às pessoas que me fizeram crer que nada é impossível, meus pais e meu irmão, Hélio Soares Damasceno, Maria Aparecida Damasceno e Ricardo Henrique Soares Damasceno.

À Ana Paula Simoni Damasceno, meu amor, a razão de minha luta por um futuro melhor. 



\section{AGRADECIMENTOS}

Ao Prof. Dr. Marcelo Zaiat pela amizade, paciência, compreensão, orientação e incentivo, principalmente pelo exemplo de profissionalismo, competência e eficiência.

Aos Engenheiros Ambientais Matheus Eduardo Martins e Monique Fernanda Geraldo Serafim pelo apoio fundamental na realização das etapas experimentais.

Ao setor de Cromatografia do Laboratório de Processos Biológicos (LPB), na pessoa da Profa. Maria Ângela Talarico Adorno, pelo empenho e profissionalismo no desenvolvimento e realização das análises cromatográficas.

Ao setor de Microbiologia do LPB, na pessoa da Profa. Maria Bernadete Amâncio Varesche, pelo suporte e profissionalismo nas análises microbiológicas.

Aos companheiros de LPB, pelos momentos de amizade, auxílio, competência, comprometimento, descontração, discussões e profissionalismo.

Aos professores e funcionários do Departamento de Hidráulica e Saneamento da Escola de Engenharia de São Carlos da Universidade de São Paulo.

À Profa. Genilda Oliveira, pelo apoio na finalização das etapas experimentais.

Aos colegas do Instituto Federal de Educação Tecnológica do Triângulo Mineiro Campus Uberlândia, pelo convívio, paciência e consideração.

À Ana Paula Simoni Damasceno pela paciência, carinho e incentivo nos momentos mais difíceis e por proporcionar momentos que se tornaram especiais.

Aos meus grandes mestres, meus pais, Hélio Soares Damasceno e Maria Aparecida Damasceno pelo apoio, carinho, amor, dedicação, paciência e orientação.

Ao meu irmão, Sgt. Ricardo Henrique Soares Damasceno, por seu exemplo de garra e comprometimento.

À Escola de Engenharia de São Carlos da Universidade de São Paulo, na pessoa de sua Ilma. Diretora Prof. Dra. Maria do Carmo Calijuri pela cessão das instalações, apoio e oportunidade.

Ao Instituto Federal de Educação Tecnológica do Triângulo Mineiro - Campus Uberlândia, na pessoa de seu Ilmo. Diretor Ruben Carlos Benvegnú Minussi pelo apoio na conclusão desta etapa profissional.

À Bayer CropScience do Brasil, na pessoa de seu Gerente de Cultura Café, Agrônomo Fábio Prata, pela doação do produto comercial utilizado nos experimentos. 
À FAPESP pela concessão da bolsa de estudos (Processo No 03/10506-7) e ao CNPq (Processo No 471764/2004-3) pelo apoio na realização do projeto.

Ao Deus de Espinosa, revelado na harmonia de tudo o que existe. 


\section{PARADISE - STRATOVARIUS}

(Música/Letra: Timo Tolkki)

Late at night I find myself again wondering and watching tv. I can't believe what's on the screen, something that I wouldn't like to see.

Many rare species will perish soon and we'll be short on food. Why do we have to be so selfish, we've got to change our attitude.

I know that I am not the only one that's worried, why don't we all wake up, and realize.

Like the birds in the sky we are flying so high, without making any kind of sacrifice. We've got so little time to undo this crime or we'll lose our Paradise.

It seems to me that there's no sense at all, nobody cares it's always the same. Mother nature's crying out in pain I know we're the one's to blame. 



\section{RESUMO}

DAMASCENO, L. H. S. Degradação do aldicarbe em biorreator anaeróbio horizontal de leito fixo. 2008. 161 f. Tese (Doutorado) - Escola de Engenharia de São Carlos, Universidade de São Paulo, São Carlos, 2008.

O objetivo principal deste trabalho foi avaliar o desempenho do biorreator anaeróbio horizontal de leito fixo (RAHLF) na degradação de aldicarbe em condições anaeróbias. Foram avaliados três níveis de oxidação: metanogênico, sulfetogênico e desnitrificante. Inicialmente foi desenvolvido o método de detecção de aldicarbe e metabólitos por meio de cromatografia líquida de alta eficiência (HPLC) para amostras aquosas sem pré-tratamento. A validação por procedimentos estatísticos confirmou a viabilidade do mesmo. O efeito do aumento da concentração de aldicarbe no desempenho dos reatores foi avaliado pelo emprego das concentrações de 5, 10, 20, 30 e 40 mg. $\mathrm{L}^{-1}$ de aldicarbe extraído do produto comercial. Os reatores foram submetidos ao tempo de detenção hidráulica de 24 horas. As melhores eficiências de remoção foram obtidas nas concentrações de 5 e 10 mg.L ${ }^{-1}$ : 93,2 e 88,9\% (metanogênico), 90,5 e 83,2\% (sulfetogênico) e 88,0 e 94,3\% (desnitrificante), respectivamente. De 20 a 40 mg.L ${ }^{-1}$, o aumento da concentração afluente de aldicarbe causou redução da eficiência de remoção em todos os níveis de oxidação avaliados. Os reatores metanogênico e sulfetogênico tiveram desempenho semelhante em todas as concentrações avaliadas, enquanto que o reator desnitrificante não foi adequado para concentrações superiores a 10 mg. $\mathrm{L}^{-1}$. Nos ensaios com reatores diferenciais na concentração de aldicarbe de 10 mg. $L^{-1}$ verificou-se que, em condições metanogênicas, não houve influência significativa da resistência à transferência de massa externa e interna na velocidade global de conversão de aldicarbe. Nestas condições, os parâmetros cinéticos aparentes corresponderam aos parâmetros cinéticos intrínsecos. A constante cinética de $1^{\mathrm{a}}$ ordem $\left(\mathrm{k}_{1}\right)$, validada por meio do Teste $\mathrm{F}$, foi de $1,46 \pm 0,09 \cdot 10^{-5} \cdot \mathrm{L} \cdot \mathrm{mgSVT}^{-1} \cdot \mathrm{h}^{-1}\left(\mathrm{r}^{2}=0,994 \pm 0,001\right)$. As análises de biologia molecular para o Domínio Bacteria constataram predominância de Chloroflexi e Epsilon proteobacterium. No Domínio Archaea houve predominância de Methanosaeta.

Palavras-chave: biorremediação, carbamato, HPLC, pesticida, RAHLF, reator biológico. 



\section{ABSTRACT}

DAMASCENO, L. H. S. Aldicarb degradation in a horizontal-flow anaerobic immobilized biomass bioreactor. 2008. $161 \mathrm{f}$. Thesis (Doctoral) - Escola de Engenharia de São Carlos, Universidade de São Paulo, São Carlos, 2008.

A bench-scale horizontal-flow anaerobic immobilized biomass (HAIB) bioreactor was assayed aiming to verify its potential use for aldicarb degradation. Three levels of oxidation were evaluated: methanogenic, sulfidogenic and denitrifying conditions. An HPLC method for the determination of aldicarb, aldicarb sulfoxide and aldicarb sulfone in liquid samples without pretreatment was developed and validated. The effects of increasing aldicarb concentration were evaluated at $5,10,20,30$ and $40 \mathrm{mg} . \mathrm{L}^{-1}$, extracted from the commercial product. The bioreactors were operated at a constant hydraulic detention time of 24 hours and $30^{\circ} \mathrm{C}$. The best-removal efficiencies were obtained at the concentrations of 5 and $10 \mathrm{mg} . \mathrm{L}^{-1}$ : 93.2 and 88.9\% (methanogenic), 90.5 and 83.2\% (sulfidogenic) e 88.0 and $94.3 \%$ (denitrifying), respectively. From 20 to $40 \mathrm{mg} . \mathrm{L}^{-1}$, the increase at the concentration of aldicarb caused reduction in the efficiency of removal in all levels of oxidation evaluated. The methanogenic and sulfidogenic bioreactors had similar performance, while the denitrifying bioreactor was not appropriate for concentrations above $10 \mathrm{mg} . \mathrm{L}^{-1}$. In the assays with differential reactors at the aldicarb concentration of $10 \mathrm{mg} . \mathrm{L}^{-1}$, the external and internal mass transfer resistance did not affect the overall substrate utilization rates. Thus, in these conditions, the apparent kinetic parameters corresponded to the intrinsic kinetic parameters. The first order rate constant $\left(k_{1}\right)$, validated through F-test, was $1.46 \pm 0.09 \cdot 10^{-5} \cdot \mathrm{L} \cdot \mathrm{mgSVT}^{-1} \cdot \mathrm{h}^{-1}$ $\left(r^{2}=0.994 \pm 0.001\right)$. The analysis of molecular biology for the Bacteria Domain showed predominance of Chloroflexi and Epsilon proteobacterium. In the Archaea Domain the predominant microrganism was Methanosaeta.

Keywords: biological reactor, bioremediation, carbamate, HAIB, HPLC, pesticide. 



\section{LISTA DE FIGURAS}

Figura 3.1. Vias de degradação do aldicarbe em plantas, animais, sedimentos e solos............39

Figura 4.1. Protocolo experimental desenvolvido...................................................................47

Figura 4.2. Representação esquemática do RAHLF em escala de bancada..............................53

Figura 4.3. Curvas normalizadas da concentração de dextrana azul e cloreto de sódio...........54

Figura 4.4. Representação esquemática do reator diferencial.................................................57

Figura 4.5. Representação esquemática do ensaio para determinação da curva de exaustão de

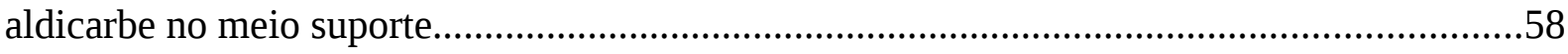

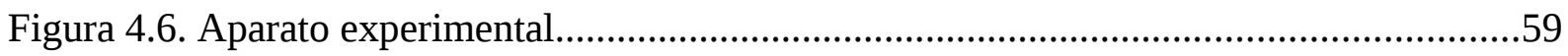

Figura 4.7. Representação esquemática do aparato experimental para determinação de

parâmetros cinéticos intrínsecos de degradação do aldicarbe sob condições metanogênicas.. 65

Figura 4.8. Aparato experimental para determinação de parâmetros cinéticos intrínsecos de

degradação do aldicarbe sob condições metanogênicas..........................................................66

Figura 4.9. Fluxograma da análise da estrutura da comunidade microbiana usando

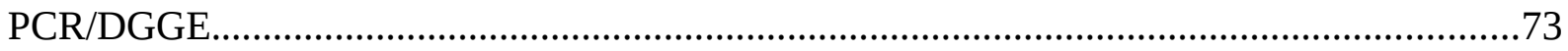

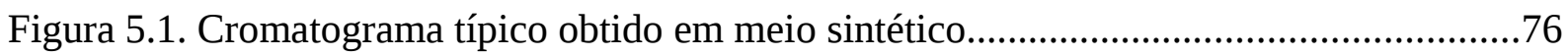

Figura 5.2. Padrão típico das Curvas F (a) e E (b)................................................................78

Figura 5.3. Padrão típico das curvas de E adimensional......................................................79

Figura 5.4. Ajuste típico do modelo de Danckwerts aos dados experimentais........................80

Figura 5.5. Variação do número de dispersão (D/u.L) em função do TDHt para os modelos propostos por Levenspiel (1999) (a) e Danckwerts (1953) (b)..............................................82

Figura 5.6. Concentração de aldicarbe no ensaio de exaustão...................................................84

Figura 5.7. Variação da concentração de aldicarbe, concentração de aldicarbe total e eficiência de remoção no período de partida sob condições metanogênicas (a), sulfetogênicas (b) e

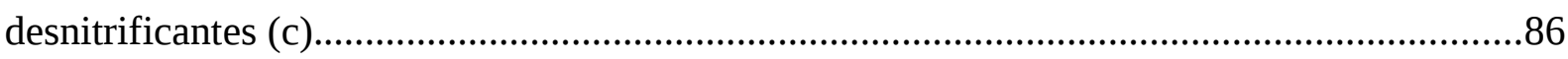

Figura 5.8. Variação da concentração de sulfato e eficiência de conversão no período de partida sob condições sulfetogênicas. .86

Figura 5.9. Variação da concentração de nitrato e nitrito no período de partida sob condições desnitrificantes

Figura 5.10. Variação da relação AI/AP no período de partida sob condições metanogênicas (a), sulfetogênicas (b) e desnitrificantes (c)... 
Figura 5.11. Variação do pH no período de partida sob condições metanogênicas (a), sulfetogênicas (b) e desnitrificantes (c).

Figura 5.12. Variação da concentração de metano e gás carbônico no biogás no período de partida sob condições metanogênicas (a), sulfetogênicas (b) e desnitrificantes (c).

Figura 5.13. Variação da composição do biogás no período de partida no sob condições metanogênicas (a), sulfetogênicas (b) e desnitrificantes (c)... 90

Figura 5.14. Variação da concentração de aldicarbe, concentração de aldicarbe total e eficiência de remoção no Ensaio 5 (a), 10 (b), 20 (c), 30 (d) e 40 (e) sob condições metanogênicas.

Figura 5.15. Variação da relação AI/AP no Ensaio 5 (a), 10 (b), 20 (c), 30 (d) e 40 (e) sob condições metanogênicas......

Figura 5.16. Variação do pH no Ensaio 5 (a), 10 (b), 20 (c), 30 (d) e 40 (e) sob condições metanogênicas.

Figura 5.17. Variação da concentração de metano e gás carbônico no biogás no Ensaio 5 (a), 10 (b), 20 (c), 30 (d) e 40 (e) sob condições metanogênicas. 96

Figura 5.18. Variação da composição do biogás no Ensaio 5 (a), 10 (b), 20 (c), 30 (d) e 40 (e) sob condições metanogênicas.

Figura 5.19. Perfis temporais ao longo do RAHLF da concentração de aldicarbe, sulfóxido de aldicarbe e sulfona de aldicarbe e eficiência de remoção de aldicarbe no Ensaio 5 (a), 10 (b), 20 (c), 30 (d) e 40 (e) sob condições metanogênicas. .99

Figura 5.20. Variação da concentração de aldicarbe, concentração de aldicarbe total e eficiência de remoção no Ensaio 5 (a), 10 (b), 20 (c), 30 (d) e 40 (e) sob condições sulfetogênicas.

Figura 5.21. Variação da concentração de sulfato e eficiência de conversão no Ensaio 5 (a), 10 (b), 20 (c), 30 (d) e 40 (e) sob condições sulfetogênicas... .104

Figura 5.22. Variação da relação AI/AP no Ensaio 5 (a), 10 (b), 20 (c), 30 (d) e 40 (e) sob condições sulfetogênicas.

Figura 5.23. Variação do pH no Ensaio 5 (a), 10 (b), 20 (c), 30 (d) e 40 (e) sob condições sulfetogênicas.

Figura 5.24. Variação da concentração de metano e gás carbônico no biogás no Ensaio 5 (a), 10 (b), 20 (c), 30 (d) e 40 (e) sob condições sulfetogênicas. 107

Figura 5.25. Variação da composição do biogás no Ensaio 5 (a), 10 (b), 20 (c), 30 (d) e 40 (e) sob condições sulfetogênicas. 108

Figura 5.26. Perfis temporais ao longo do RAHLF da concentração de aldicarbe, sulfóxido de 
aldicarbe e sulfona de aldicarbe e eficiência de remoção de aldicarbe no Ensaio 5 (a), 10 (b), 20 (c), 30 (d) e 40 (e) sob condições sulfetogênicas

Figura 5.27. Perfis temporais ao longo do RAHLF da concentração de sulfato e sulfeto no Ensaio 5 (a), 10 (b), 20 (c), 30 (d) e 40 (e) sob condições sulfetogênicas.

Figura 5.28. Variação da concentração de aldicarbe, concentração de aldicarbe total e eficiência de remoção no Ensaio 5 (a), 10 (b), 20 (c) e 30 (d) sob condições desnitrificantes.

Figura 5.29. Variação da concentração de nitrato e nitrito no Ensaio 5 (a), 10 (b), 20 (c) e 30 (d) sob condições desnitrificantes

Figura 5.30. Variação da concentração de alcalinidade a bicarbonato no Ensaio 5 (a), 10 (b), 20 (c) e 30 (d) sob condições desnitrificantes.

Figura 5.31. Variação do pH no Ensaio 5 (a), 10 (b), 20 (c) e 30 (d) sob condições desnitrificantes

Figura 5.32. Variação da concentração de metano e gás carbônico no biogás no Ensaio 5 (a), 10 (b), 20 (c) e 30 (d) sob condições desnitrificantes

Figura 5.33. Variação da composição do biogás no Ensaio 5 (a), 10 (b), 20 (c) e 30 (d) sob condições desnitrificantes.

Figura 5.34. Perfis temporais ao longo do RAHLF da concentração de aldicarbe, sulfóxido de aldicarbe e sulfona de aldicarbe e eficiência de remoção de aldicarbe no Ensaio 5 (a), 10 (b), 20 (c) e 30 (d) sob condições desnitrificantes

Figura 5.35. Perfis temporais ao longo do RAHLF da concentração de nitrato e nitrito no Ensaio 5 (a), 10 (b), 20 (c) e 30 (d) sob condições desnitrificantes.

Figura 5.36. Efeito do aumento da concentração afluente de aldicarbe na sua remoção

Figura 5.37. Carga removida de aldicarbe (CRA) com o aumento da carga aplicada de aldicarbe (CAA)

Figura 5.38. Variação do parâmetro cinético aparente de degradação de primeira ordem (k1ap) e ordem zero (k0ap)....

Figura 5.39. Perfil de concentração de aldicarbe no meio líquido em função do tempo para as velocidades de escoamento de 4,2 (a), 25,5 (b), 78,3 (c) e 203,7 cm.h-1 (d).

Figura 5.40. Perfil de robs em função da concentração de substrato no meio líquido para as velocidades de escoamento de 4,2 (a), 25,5 (b), 78,3 (c) e 203,7 cm.h-1 (d).

Figura 5.41. Variação da concentração mínima de substrato com o aumento da concentração de aldicarbe no RAHLF.

Figura 5.42. Perfis temporais ao longo do RAHLF da concentração experimental e simulada 
de aldicarbe no Ensaio 5 (a), 10 (b), 20 (c), 30 (d) e 40 (e) sob condições metanogênicas....133 Figura 5.43. Observações morfológicas sob microscopia de contraste de fase e epifluorescência, referentes às amostras do reator metanogênico

Figura 5.44. Observações morfológicas sob microscopia de contraste de fase e

epifluorescência, referentes às amostras do reator sulfetogênico.

Figura 5.45. Observações morfológicas sob microscopia de contraste de fase e epifluorescência, referentes às amostras do reator desnitrificante. 138

Figura 5.46. Perfil de bandas de DGGE usando primers para o Domínio Bacteria.

Figura 5.47. Diversidade de filos revelada pelo seqüenciamento das bandas de DGGE com relação ao Domínio Bactéria.

Figura 5.48. Árvore filogenética de consenso baseado nas seqüências de bandas recortadas do DGGE com primers para o Domínio Bacteria.

Figura 5.49. Perfil de bandas de DGGE usando primers para o Domínio Archaea. 144

Figura 5.50. Árvore filogenética de consenso baseado nas seqüências de bandas recortadas do DGGE com primers para o Domínio Archaea. 


\section{LISTA DE TABELAS}

Tabela 3.1 - Características principais do aldicarbe. .35

Tabela 4.1 - Gradiente de eluição utilizado para determinar aldicarbe e seus metabólitos por HPLC.

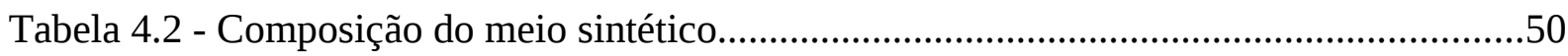

Tabela 4.3 - Concentrações dos analitos utilizados nas curvas de calibração..........................51

Tabela 4.4 - ANOVA utilizada no Teste F..........................................................................51

Tabela 4.5 - Testes de linearidade e eficiência de regressão..................................................51

Tabela 4.6 - Parâmetros e equações adaptados dos modelos propostos por Levenspiel (1999).

Tabela 4.7 - Velocidades de escoamento superficial avaliadas e tempos de detenção hidráulica

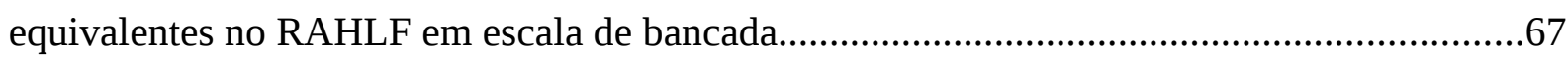

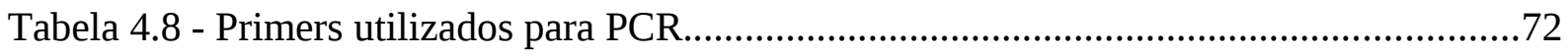

Tabela 4.9 - Programação do termociclador para amplificação dos fragmentos do RNAr 16S.

72

Tabela 5.1 - Curvas de regressão e testes de eficiência de regressão......................................76

Tabela 5.2 - Resultados dos testes de linearidade com significância estatística de 95\%..........76

Tabela 5.3 - Limite de detecção (LOD) e limite de quantificação (LOQ)

dos analitos em água e meio sintético.

Tabela 5.4 - Precisão e precisão instrumental do método para cada analito em meio sintético.

Tabela 5.5 - Valores médios dos parâmetros dos modelos propostos por Levenspiel (1999).. 81

Tabela 5.6 - Valores médios dos parâmetros do modelo de Danckwerts (1953)..... .82

Tabela 5.7 - Valores médios da concentração de aldicarbe, seus metabólitos e aldicarbe total e eficiências de remoção para diferentes condições avaliadas no reator metanogênico. 98

Tabela 5.8. Parâmetros cinéticos aparentes determinados para diferentes concentrações de aldicarbe sob condições metanogênicas. 100 Tabela 5.9 - Valores médios da concentração de aldicarbe, seus metabólitos e aldicarbe total e eficiências de remoção para diferentes condições avaliadas no reator sulfetogênico

Tabela 5.10. Parâmetros cinéticos aparentes determinados para diferentes concentrações de aldicarbe sob condições sulfetogênicas. 
Tabela 5.11 - Valores médios da concentração de aldicarbe, seus metabólitos e aldicarbe total e eficiências de remoção para diferentes condições avaliadas no reator desnitrificante.

Tabela 5.12. Parâmetros cinéticos aparentes determinados para diferentes concentrações de aldicarbe sob condições desnitrificantes.

Tabela 5.13. Eficiências médias de remoção de aldicarbe em condições metanogênicas, sulfetogênicas e desnitrificantes

Tabela 5.14. Parâmetros da equação exponencial ajustados para os ensaios com reator diferencial.

Tabela 5.15. Velocidade inicial de consumo de substrato observada (Robs), velocidade inicial específica de consumo de substrato observada (robs) e módulo de Thiele observado ( $\phi$ obs) para as diferentes velocidades de escoamento superficial.

Tabela 5.16. Parâmetros cinéticos determinados empregando-se reatores diferenciais para diferentes velocidades de escoamento superficial.

Tabela 5.17. Parâmetros cinéticos de degradação do aldicarbe sob condições metanogênicas no RAHLF e no reator diferencial

Tabela 5.18. Parâmetros da equação polinomial de segunda ordem.

Tabela 5.19. Parâmetros utilizados na simulação dos perfis temporais

Tabela 5.20. Parâmetros determinados para emprego do Teste F.....

Tabela 5.21. Ocorrência das morfologias observadas nas amostras de biomassa imobilizada.

Tabela 5.22. Identificação das bandas recortadas e seqüências do gel de DGGE com primers do Domínio Bacteria.

Tabela 5.23. Identificação das bandas recordadas e seqüências do gel de DGGE com primers do Domínio Archaea. 


\section{LISTA DE ABREVIATURAS E SIGLAS}

$\mathrm{AB}$

ALM

ANOVA

ANVISA

BLAST

BTEX

CAS

CEE

CONAMA

CSTR

$\mathrm{CV}$

DDGE

DNA

DQO

EPA

ER

GD-TA

GD-TF

HPLC

IUPAC

LAS

LD

LOD

LOQ

MSDS

NCBI

PCR

PD

RAHLF

RNA
Alcalinidade a bicarbonato.

Ajuste ao modelo linear.

Análise de variância.

Agência Nacional de Vigilância Sanitária.

Ferramenta de busca de homologia por alinhamento local.

Benzeno, tolueno, etilbenzeno e xileno.

Chemical Abstracts Service.

Comunidade Econômica Européia.

Conselho Nacional de Meio Ambiente.

Reator agitado de mistura completa.

Coeficiente de variação.

Eletroforese em gel de gradiente desnaturante.

Ácido desoxirribonucléico.

Demanda química de oxigênio.

Agência de Proteção Ambiental dos Estados Unidos.

Eficiência de regressão.

Grande dispersão, tanque aberto.

Grande dispersão, tanque fechado.

Cromatografia líquida de alta eficiência.

União Internacional de Química Pura e Aplicada.

Alquilbenzeno Linear Sulfonado

Dose letal.

Limite de detecção.

Limite de quantificação.

Ficha de segurança de material.

National Center for Biotechnology Information.

Reação em cadeia da polimerase.

Pequena dispersão.

Reator anaeróbio horizontal de leito fixo.

Ácido ribonucleico. 
Somatório dos erros ao quadrado.

TDH

Tempo de detenção hidráulica.

UASB

Manta de lodo anaeróbio ascendente.

UV

Ultravioleta.

VR

Validade da regressão.

WHO

Organização Mundial da Saúde. 


\title{
LISTA DE SÍMBOLOS
}

\author{
$\mathrm{K}_{\mathrm{oc}} \quad$ Coeficiente de adsorção à matéria orgânica. \\ $\mathrm{K}_{\mathrm{ow}}$ \\ Coeficiente de partição entre o octanol e a água. \\ $\mathrm{pK}_{\mathrm{a}}$ \\ Constante de dissociação. \\ ${ }^{\circ} \mathrm{C}$ \\ Graus Celsius. \\ $\lambda$ \\ Comprimento de onda. \\ $\Sigma$ \\ Somatório. \\ $\alpha$ \\ Nível de significância. \\ $r^{2}$ \\ Quadrado do coeficiente de correlação de Pearson. \\ $\mathrm{r}_{\text {max }}^{2}$ \\ Quadrado do coeficiente máximo de correlação de Pearson. \\ $\mathrm{F}$ \\ Curva F. \\ $\mathrm{E}$ \\ Curva E. \\ $\sigma^{2}$ \\ Variância. \\ $\sigma_{\theta}^{2}$ \\ Variância adimensional. \\ $\mathrm{E}_{\theta}$ \\ E adimensional. \\ $\theta$ \\ Tempo adimensional. \\ D/u.L \\ Número de dispersão. \\ $\mathrm{N}$ \\ Número de reatores. \\ $\mathrm{C} / \mathrm{C}_{0}$ \\ Curva normalizada. \\ $\mathrm{S}_{\mathrm{b}}$ \\ Concentração de substrato no meio líquido. \\ $\mathrm{R}_{\mathrm{obs}}$ \\ Velocidade observada de consumo de substrato. \\ robs \\ Velocidade específica observada de consumo de substrato. \\ $\mathrm{X}$ \\ Concentração de biomassa no reator. \\ $\phi_{\text {obs }}$ \\ Módulo de Thiele observado. \\ $\mathrm{R}_{\mathrm{eq}}$ \\ Raio da esfera equivalente. \\ $\mathrm{D}_{\mathrm{e}}$ \\ Difusidade efetiva do substrato na biopartícula. \\ $\mathrm{r}_{\max }$ \\ Velocidade específica máxima de consumo de substrato. \\ Ks \\ Constante de saturação. \\ $\mathrm{S}_{\min }$ \\ Concentração mínima de substrato no meio líquido. \\ $\mathrm{k}_{1}$ \\ Constante cinética de primeira ordem. \\ $\mathrm{k}_{0}$ \\ Constante cinética de ordem zero.
}





\section{SUMÁRIO}

1 INTRODUÇÃO

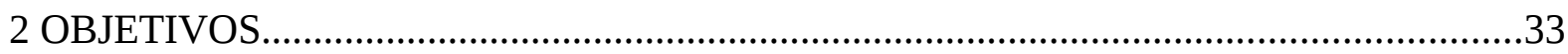

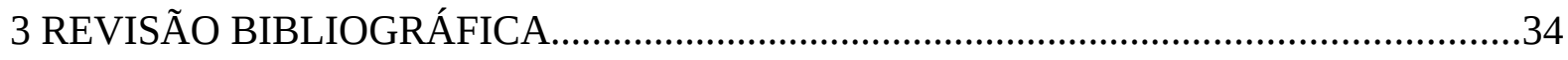

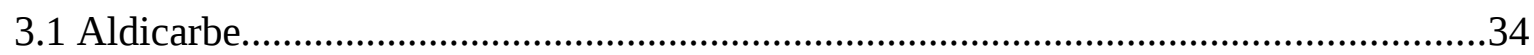

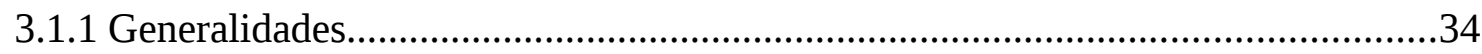

3.1.2 Toxicidade.................................................................................................

3.1.3 Contaminação de águas superficiais e subterrâneas.................................................36

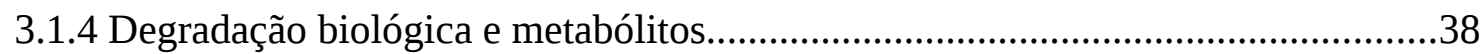

3.1.5 Tecnologias empregadas na degradação/remoção de aldicarbe em águas.............41

3.1.5.1 Processos biológicos...................................................................................

3.1.5.2 Outras tecnologias.......................................................................................43

3.1.6 Métodos de deteç̧ão do aldicarbe e metabólitos....................................................43

3.2 Reator anaeróbio horizontal de leito fixo (RAHLF).....................................................44

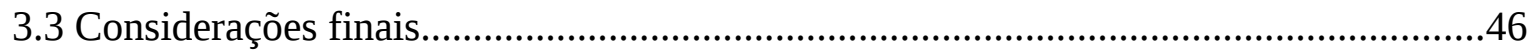

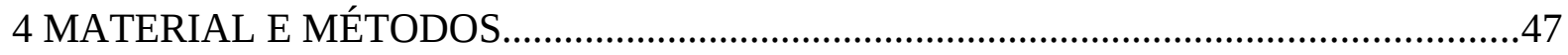

4.1 Desenvolvimento de método de detecção de aldicarbe, sulfóxido de aldicarbe e sulfona de aldicarbe por cromatografia líquida de alta eficiência (HPLC)........................................48

4.1.1 Instrumentação e condições analíticas......................................................................48

4.1.2 Padrões cromatográficos e solventes....................................................................48

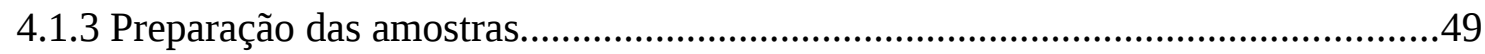

4.1.4 Validação do método...........................................................................................49

4.1.5 Limite de detecção (LOD) e limite de quantificação (LOQ)....................................51

4.1.6 Precisão.........................................................................................................52

4.1.7 Precisão instrumental.......................................................................................

4.2 Ensaios preliminares no RAHLF........................................................................52

4.2.1 Hidrodinâmica em condições abióticas.................................................................52

4.2.1.1 Reator anaeróbio horizontal de leito fixo (RAHLF).......................................52

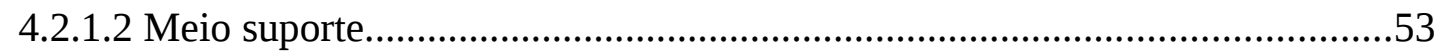

4.2.1.3 Procedimento experimental..............................................................................53

4.2.1.4 Avaliação do regime de escoamento.............................................................54 
4.2.2 Adsorção do aldicarbe no meio suporte .56

4.3 Avaliação da degradação do aldicarbe na presença de diferentes aceptores de elétrons

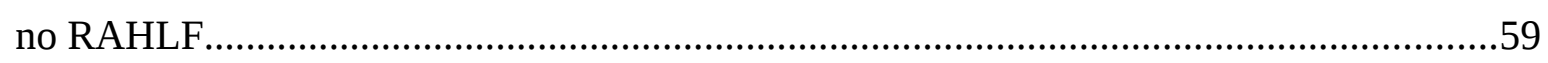

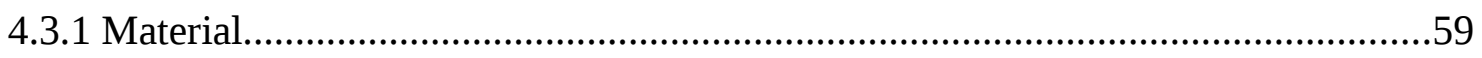

4.3.1.1 Reator anaeróbio horizontal de leito fixo (RAHLF)..................................59

4.3.1.2 Meio suporte para imobilização da biomassa...............................................60

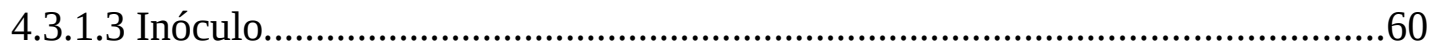

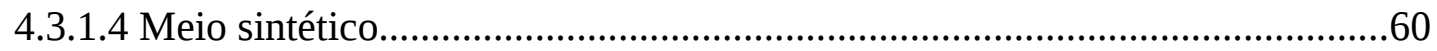

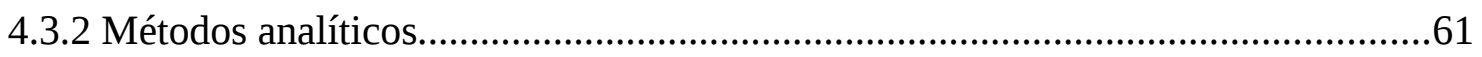

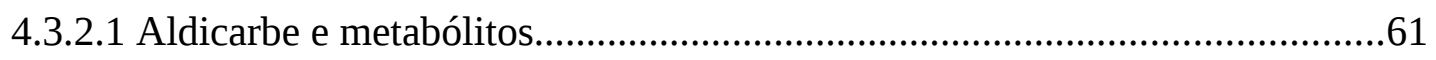

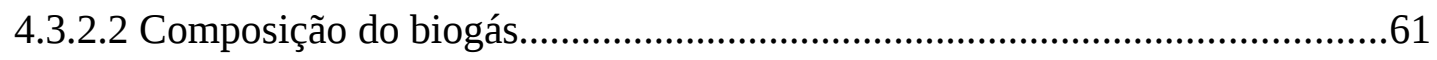

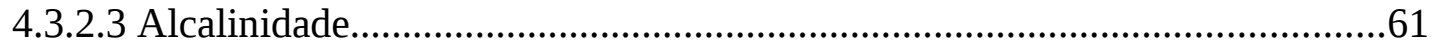

4.3.2.4 Sulfato, sulfeto, nitrito e nitrato................................................................62

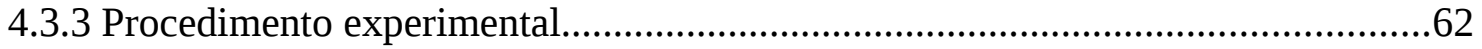

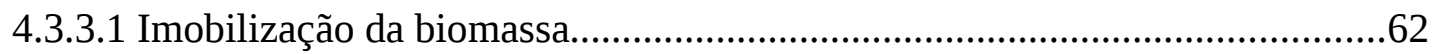

4.3.3.2 Extração de aldicarbe..................................................................................62

4.3.3.3 Estabilidade do aldicarbe no frasco de alimentação.....................................63

4.3.3.4 Avaliação do efeito do aumento da concentração na degradação do aldicarbe na presença de diferentes aceptores de elétrons......................................................63

4.4 Cinética da degradação biológica do aldicarbe sob condições metanogênicas.............65

4.4.1 Avaliação da transferência de massa externa e interna........................................65

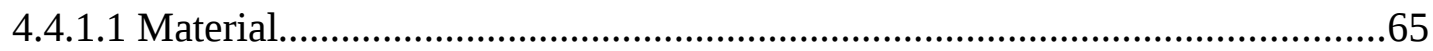

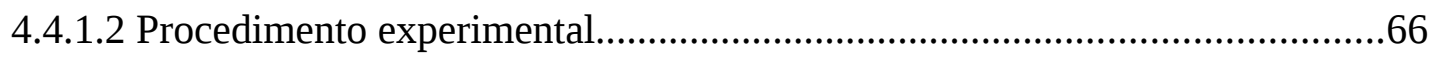

4.4.1.3 Tratamento dos dados experimentais.......................................................67

4.4.2 Determinação dos parâmetros cinéticos intrínsecos de degradação......................69

4.4.3 Validação dos parâmetros cinéticos intrínsecos.................................................70

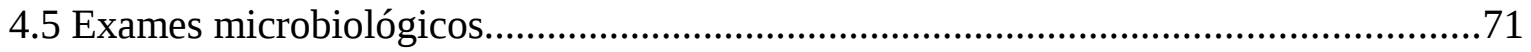

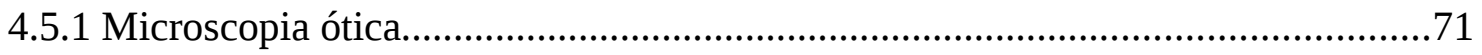

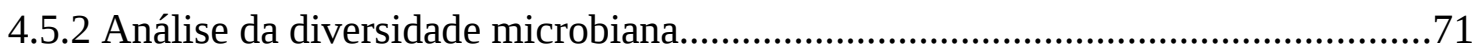

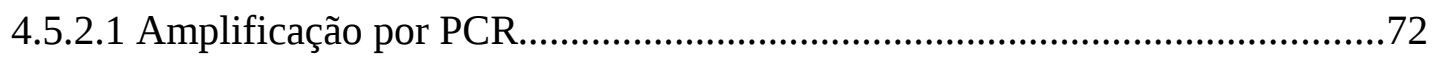

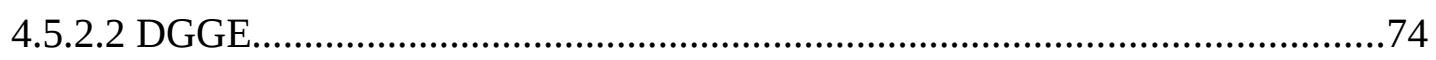

4.5.2.3 Análises de Seqüenciamento...................................................................74

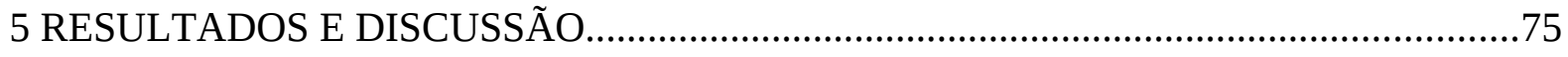

5.1 Desenvolvimento de método de detecção de aldicarbe, sulfóxido de aldicarbe e sulfona 
de aldicarbe por cromatografia líquida de alta eficiência (HPLC)....................................75

5.1.1 Determinação de aldicarbe, sulfóxido de aldicarbe e sulfona de aldicarbe...........75

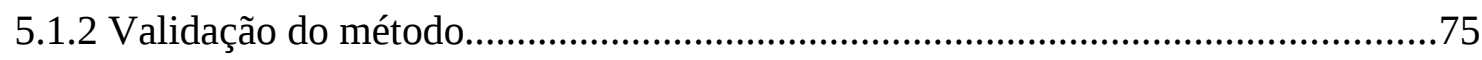

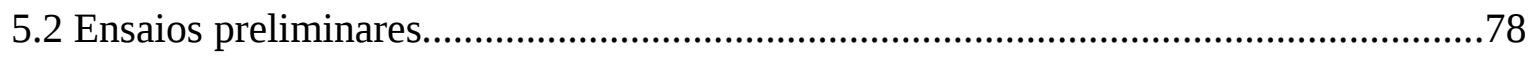

5.2.1 Hidrodinâmica do RAHLF em condições abióticas...........................................78

5.2.1.1 Modelos propostos por Levenspiel (1999).................................................78

5.2.1.2 Modelo proposto por Danckwerts...........................................................79

5.2.2 Avaliação da adsorção do aldicarbe em espuma de poliuretano...........................83

5.3 Degradação do aldicarbe na presença de diferentes aceptores de elétrons...................85

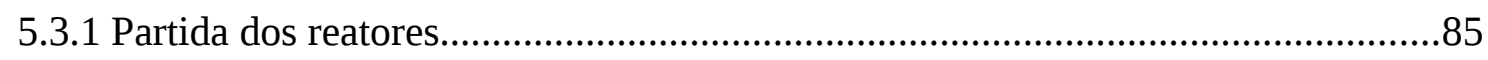

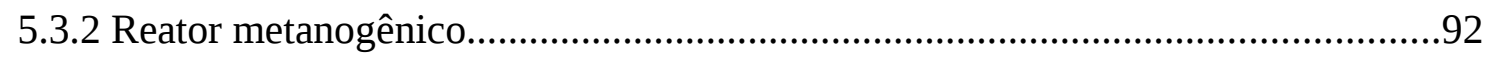

5.3.3 Reator sulfetogênico....................................................................................100

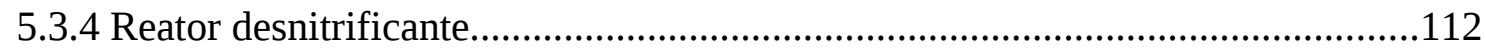

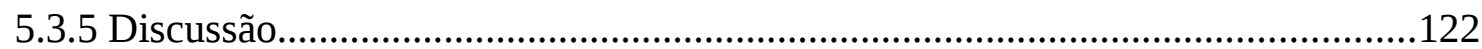

5.4 Cinética da degradação biológica do aldicarbe sob condições metanogênicas -

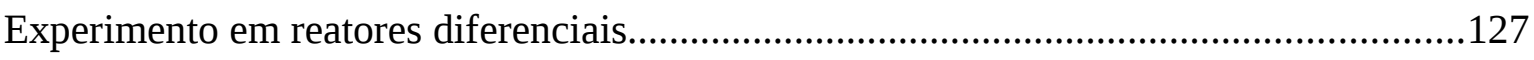

5.4.1 Avaliação da transferência de massa externa e interna......................................127

5.4.2 Determinação dos parâmetros cinéticos intrínsecos de degradação....................129

5.4.3 Validação dos parâmetros cinéticos intrínsecos..................................................131

5.5 Caracterização microbiológica da degradação do aldicarbe no RAHLF...................134

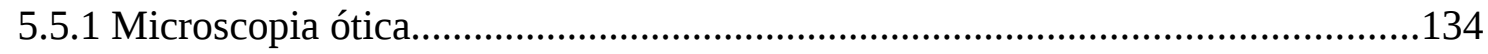

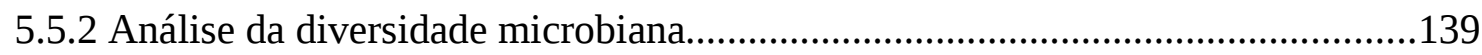

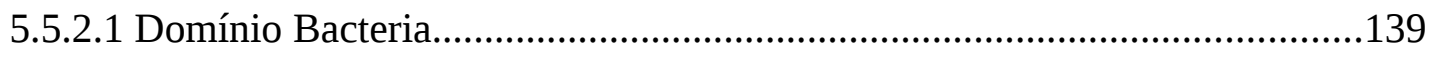

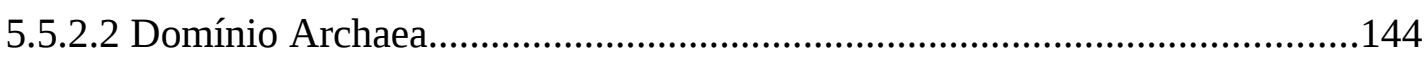

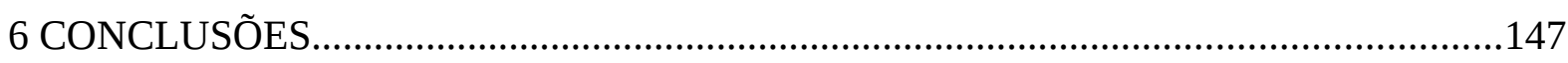

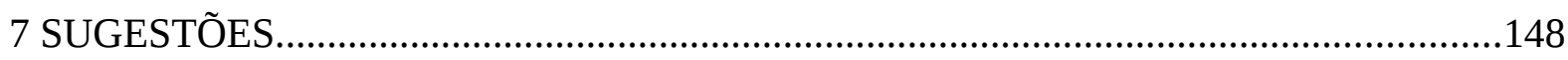

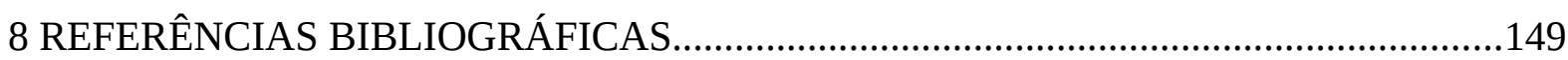





\section{INTRODUÇÃO}

O crescimento exponencial da população mundial foi acompanhado por uma crescente demanda por alimentos. A agricultura se desenvolveu pelo uso freqüente de agrotóxicos ${ }^{1}$ de forma a aumentar, indiretamente, a produtividade no campo. Embora tenha tido seu objetivo cumprido, o uso indiscriminado e incorreto destes compostos pode levar à degradação dos recursos naturais, muitas vezes de forma irreversível, levando a desequilíbrios biológicos e ecológicos, além da contaminação de diferentes matrizes ambientais.

O aldicarbe é o princípio ativo do Temik $^{\circledR}$ 150, vendido no Brasil pela Bayer CropScience $^{\circledR}$. É um carbamato de amplo espectro, sendo considerado um dos agrotóxicos mais eficazes no campo. É utilizado no Brasil em culturas de importante valor econômico, como café, cana-de-açúcar, citrus e batata.

Com o investimento maciço nos biocombustíveis nos últimos anos e a conseqüente expansão da cana-de-açúcar no país, o aldicarbe tem desempenhado papel importante no controle de nematóides e cigarrinha-das-raízes, incrementando significativamente a produtividade no campo. Como as outras práticas utilizadas no controle dessas pragas não têm surtido efeito, estima-se que lavouras que não utilizem o produto possam ter sua produtividade reduzida em até 30\% (DINARDO-MIRANDA, 2007).

Em que pese suas excelentes propriedades praguicidas, o aldicarbe é um dos compostos mais tóxicos já registrados, fazendo com que seu uso em muitos países seja restrito. Sua elevada solubilidade em água e baixa hidrofobicidade faz com que, em condições específicas, haja o risco de contaminação de águas superficiais e subterrâneas. Há registro de contaminação de águas superficiais e subterrâneas no exterior (JONES e ESTES, 1995). No Brasil há registros isolados de lixiviação do aldicarbe em águas superficiais e subterrâneas (MARQUES; COTRIM; PIRES, 2007; RIGITANO; GOUVÊA, 1995).

Além dos riscos intrínsecos ao seu uso legal, no Brasil percebe-se a existência de desvios do uso do aldicarbe e outros produtos para outros fins não agrícolas. É popularmente conhecido como "chumbinho" sendo muito utilizado pela população leiga como raticida,

1 A legislação brasileira adotou e definiu o termo agrotóxico (Lei 7.802/89 e Decretos 98.816/90 e 4.074/2002) como: (a) os produtos e os agentes de processos físicos, químicos ou biológicos, destinados ao uso nos setores de produção, no armazenamento e beneficiamento de produtos agrícolas, nas pastagens, na proteção de florestas, nativas ou implantadas, e de outros ecossistemas e também de ambientes urbanos, hídricos e industriais, cuja finalidade seja alterar a composição da flora ou da fauna, a fim de preservá-las da ação danosa de seres vivos considerados nocivos; (b) substâncias e produtos, empregados como desfolhantes, dessecantes, estimuladores e inibidores de crescimento (BRASIL, 1989; BRASIL, 1990; BRASIL, 2002). 
ocasionando também o envenenamento de outros animais, domésticos ou não (XAVIER, 2004). Em virtude disso, a Agência Nacional de Vigilância Sanitária (ANVISA) fez a reavaliação do produto em 2006, com sua venda no Brasil restrita aos estados de São Paulo, Minas Gerais e Bahia.

Apesar do controle que vem sendo imposto tanto pela empresa que detém o registro quanto pelos órgãos governamentais responsáveis, o eventual risco do uso inadequado do produto faz com que seja necessária a avaliação de tecnologias para sua remediação. E as condições de degradação estabelecidas desempenham importante papel nesse processo.

Em condições aeróbias, o aldicarbe é biologicamente metabolizado a sulfóxido e sulfona de aldicarbe, sendo estes considerados seus metabólitos principais. Em condições anaeróbias, o metabolismo é desviado à formação de oximas e nitrilas. Sabendo que o sulfóxido e sulfona de aldicarbe exercem toxicidade semelhante ao composto principal, o emprego de condições anaeróbias reduz o potencial de toxicidade de uma matriz contaminada.

O reator anaeróbio horizontal de leito fixo (RAHLF) tem sido usado com sucesso para degradação de diferentes compostos tóxicos (fenol, BTEX, e PCP) (BOLAÑOS et al. (2001), OLIVEIRA et al. (2004), DE NARDI et al. (2005), GUSMÃO et al. (2006), SAIA et al. (2007), BARALDI et al. (2008)) tornando-se uma tecnologia em potencial para a biorremediação e/ou estudos de processos de degradação.

Nesse contexto, avaliou-se a possibilidade de degradar anaerobicamente o aldicarbe, em diferentes níveis de oxidação, empregando-se o RAHLF como ferramenta para análise do processo. 


\section{OBJETIVOS}

O principal objetivo deste trabalho foi investigar o desempenho do biorreator anaeróbio horizontal de leito fixo (RAHLF) na degradação do aldicarbe como única fonte de carbono. Foram estabelecidos os seguintes objetivos específicos:

a) Desenvolver método de deteç̧ão e quantificação do aldicarbe e seus metabólitos utilizando cromatografia líquida de alta eficiência (HPLC).

b) Avaliar o efeito do aumento da concentração na degradação do aldicarbe em diferentes níveis de oxidação (metanogênese, sulfetogênese e desnitrificação).

c) Avaliar a cinética de degradação do aldicarbe em condições metanogênicas.

d) Caracterizar a comunidade microbiana nos RAHLFs utilizando-se de técnicas de Biologia Molecular (PCR/DGGE e seqüenciamento dos fragmentos do gene RNAr 16S). 


\section{REVISÃO BIBLIOGRÁFICA}

\subsection{Aldicarbe}

\subsubsection{Generalidades}

$\mathrm{O}$ inseticida aldicarbe $\left(\mathrm{C}_{7} \mathrm{H}_{14} \mathrm{~N}_{2} \mathrm{O}_{2} \mathrm{~S}\right)$ é um carbamato de amplo espectro utilizado para controlar grande variedade de insetos, ácaros e nematóides. Comercializado em formulação granulada a $15 \%$ (Temik $150^{\circledR}$ ), após a aplicação no solo é absorvido pelas raízes sendo transportado posteriormente para as folhas. A eficiente ação sistêmica nas plantas e as excelentes propriedades praguicidas fazem com que seja utilizado em culturas de importante valor econômico no Brasil, principalmente em cultivos de café, citros, cana-de-açúcar e batata.

O aldicarbe é muito solúvel em água e o uso em excesso pode ocasionar sua migração do solo para o aqüífero subjacente contaminando rapidamente não só reservas de água subterrânea, mas também lagos e regiões costeiras (KAZUMI; CAPONE, 1995). A Tabela 3.1 apresenta as principais características do aldicarbe (WHO, 1991).

\subsubsection{Toxicidade}

O aldicarbe é um dos agrotóxicos de maior toxicidade já registrados. $A \operatorname{LD}_{50}$ (dose requerida para causar a morte de 50\% dos indivíduos avaliados) está entre 0,3 e 0,9 mg. $\mathrm{kg}^{-1}$ de peso vivo dos animais já testados (WHO, 1991). Supondo-se a mesma sensibilidade em seres humanos, aproximadamente $50 \mathrm{mg}$ seriam suficientes para causar a morte de um adulto típico (60 kg) (COX, 1992). Ainda, segundo Cox (1992), em testes de laboratório, o aldicarbe causou danos crônicos ao sistema nervoso, suprimiu o sistema imunológico e causou efeitos adversos em fetos de pequenos animais. É também tóxico a aves, peixes, camarões, abelhas e minhocas. 
Tabela 3.1 - Características principais do aldicarbe.

\begin{tabular}{|c|c|}
\hline Nome comum/técnico & Aldicarbe \\
\hline Nome científico (IUPAC) & $\begin{array}{l}\text { 2-metil-2-(metiltio)-propionaldeído-O-(metilcarbamoil)- } \\
\text { oxima }\end{array}$ \\
\hline Sinonímia & $\begin{array}{l}\text { 2-metil-2-(metiltio)-propanal-O-((metilamino)carbonil)- } \\
\text { oxima, aldicarb, C11015, carbamil, carbamoil, carbanolato, } \\
\text { ENT 27,093, NCI-CO8640, OMS-771, Temic, Temik }{ }^{\circledR} \text {, } \\
\text { UC-21149, UE2275000, Union Carbide } 21149\end{array}$ \\
\hline Número CAS & $116-06-3$ \\
\hline Fórmula molecular & $\mathrm{C}_{7} \mathrm{H}_{14} \mathrm{~N}_{2} \mathrm{O}_{2} \mathrm{~S}$ \\
\hline Massa molar & 190,3 \\
\hline \multicolumn{2}{|l|}{ Estrutura química } \\
\hline Estado físico & $\begin{array}{l}\text { Sólido cristalino branco, inodoro ou com leve odor de } \\
\text { enxofre. }\end{array}$ \\
\hline \multicolumn{2}{|c|}{ Solubilidade (m.m ${ }^{-1}$ em $25^{\circ} \mathrm{C}$ ) } \\
\hline Água & $0,6 \%$ \\
\hline Acetona & $40 \%$ \\
\hline Clorofórmio & $35 \%$ \\
\hline Tolueno & $10 \%$ \\
\hline Temperatura de fusão & $100{ }^{\circ} \mathrm{C}$ \\
\hline Temperatura de ebulição & $\begin{array}{l}\text { Não determinada, decompõe antes de atingir a temperatura } \\
\text { de ebulição. }\end{array}$ \\
\hline $\mathrm{K}_{\mathrm{oc}}$ & $25-79$ \\
\hline Pressão de vapor $\left(25^{\circ} \mathrm{C}\right)$ & $13 \mathrm{mPa}\left(1 \cdot 10^{-4} \mathrm{mmHg}\right)$ \\
\hline $\log K_{o w}$ & 1,359 \\
\hline $\mathrm{pK}_{\mathrm{a}}$ & 11,7 \\
\hline Outras características & $\begin{array}{l}\text { Estável (exceto na presença de álcali forte), não corrosivo a } \\
\text { metais e plásticos, não é inflamável, perigoso se misturado à } \\
\text { água. }\end{array}$ \\
\hline
\end{tabular}

Entre os componentes do Temik $150^{\circledR}$, encontra-se também o diclorometano (MSDS², 1992 apud COX, 1992) O diclorometano é um componente ativo de um fumigante utilizado em morangos e grãos e também participa como ingrediente “inerte” em mais de 1750

2 MSDS reference for crop protection chemicals (1992). 4th ed. New York: Chemical and Pharmaceutical Press. 
agrotóxicos (U.S. EPA ${ }^{3}, 1985$ apud COX, 1992). Em seres humanos, a exposição ao diclorometano causa mudanças no total de células sanguíneas, diminuição de audição e visão, perda de coordenação e morte. Em animais de laboratório, a exposição causa irritação nos olhos, danos aos rins e fígado, danos aos genes e câncer. É classificado pela EPA como um provável carcinogênico humano (U. S. DEPARTMENT OF HEALTH AND HUMAN SERVICES ${ }^{4}, 1991$ apud COX, 1992).

\subsubsection{Contaminação de águas superficiais e subterrâneas}

O aldicarbe e seus produtos de degradação são geralmente móveis no solo, principalmente em solos arenosos ou de textura média, bem como a sua adsorção é função do conteúdo de matéria orgânica (LORBER et al., 1989). O deslocamento de agrotóxicos no solo é função das propriedades do composto, da sua velocidade de degradação e movimento de água, entre outros fatores. Em áreas caracterizadas por solos rasos ou por uma combinação de fatores (solo arenoso, baixo pH do solo, baixa temperatura do solo, chuvas intensas, etc.), a aplicação do aldicarbe pode resultar no transporte de resíduos até o lençol freático (BARBOSA; RIGITANO, 1994).

No exterior, há relatos de contaminação nos Estados Unidos e no Canadá. O aldicarbe é um contaminante persistente e que se estende sobre uma vasta área no aqüífero de Long Island (Nova Iorque). Outros locais em que foi constatada a contaminação do lençol freático foram Wisconsin, Califórnia e Flórida (MILES; DELFINO, 1985; MOYE; MILES, 1989). Em 22 estados americanos foram detectados resíduos de aldicarbe em lençóis freáticos (U.S. EPA, 1988). As concentrações encontradas variaram de 1 a $50 \mu \mathrm{g} . \mathrm{L}^{-1}$ (COHEN; EIDEN; LORBER, 1986; DE HANN, 1988). No Canadá, constatou-se a contaminação em poços privados (concentrações superiores a $6 \mu \mathrm{g} . \mathrm{L}^{-1}$ ) e em lençóis freáticos em Quebec (concentração máxima de $28 \mu \mathrm{g} \cdot \mathrm{L}^{-1}$ ) e Ontário (concentração máxima de $1.1 \mu \mathrm{g} . \mathrm{L}^{-1}$ ) (HIEBSCH, 1988). A contaminação do aqüífero de Long Island em concentrações superiores a $500 \mu \mathrm{g} . \mathrm{L}^{-1}$ foi atribuída a uma combinação de vários fatores (alta precipitação, solo arenoso, baixas temperaturas do solo e pequena profundidade do lençol) que favoreceram a lixiviação. O uso intensivo do Temik ${ }^{\circledR}$ também favoreceu a contaminação nestes locais.

No Brasil, Piffer e Rigitano (1991) constataram intensa lixiviação do aldicarbe e seus

3 USEPA. (1985). EPA announces full-scale investigation of methylene chloride risk. Environmental News. (October 9).

4 U. S. DEPARTMENT OF HEALTH AND HUMAN SERVICES. Public Health Service. Agency for Toxic Substances and Disease Registry (1991) Toxicological profile for methylene chloride. Washigton D.C. 
resíduos em dois solos da região de Lavras (MG) até a profundidade de $50 \mathrm{~cm}$. Porém a falta de informações relacionadas com a velocidade de degradação em maiores profundidades impediu uma melhor avaliação do potencial de contaminação do lençol freático nestes solos. Rigitano e Gouvêa (1995) detectaram a presença de resíduos de aldicarbe em região produtora de batata, localizada na bacia hidrográfica do córrego Cambuí na cidade de Maria da Fé (MG). Em amostras coletadas nos drenos de uma área cultivada, foram determinados níveis máximos de resíduos de $5 \mu \mathrm{g} . \mathrm{L}^{-1}$. Para amostras no leito do córrego, as concentrações foram inferiores, possivelmente devido aos efeitos de diluição no mesmo. O aldicarbe também foi detectado em águas superficiais pertencentes à bacia hidrográfica do Rio Ribeira de Iguape (SP) (MARQUES; COTRIM; PIRES, 2007).

Até a Resolução CONAMA n 20, de 15 de junho de 1986 (BRASIL, 1986), a concentração máxima de carbamatos totais em águas superficiais classificadas como sendo das classes 1 e 2 era de $10 \mu \mathrm{g} . \mathrm{L}^{-1}$ e de $100 \mu \mathrm{g} . \mathrm{L}^{-1}$ para a classe 3. No entanto, a partir da Resolução CONAMA No 357, de 17 de março de 2005 (BRASIL, 2005), estabeleceu-se somente a máxima concentração de carbaril, excluindo-se o aldicarbe como parâmetro de controle. Para águas subterrâneas, a Resolução CONAMA nº 396, de 3 de abril de 2008, estabelece a concentração máxima total de aldicarbe, sulfóxido de aldicarbe e sulfona de

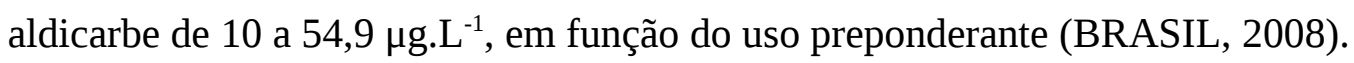

Como o aldicarbe tem demonstrado ser fundamental para obtenção de maiores produtividades na cultura da cana-de-açúcar (DINARDO-MIRANDA, 2007) e essa encontrase em expansão em função da difusão dos biocombustíveis no país, o risco de contaminação em áreas de agricultura intensiva pode se tornar significativo. Isto tem levado a um aumento na demanda no monitoramento do aldicarbe e seus metabólitos, mas ainda observa-se a falta de um programa de controle integrado no país (NUNES et al., 2000). Ademais, como a legislação não prevê a avaliação da presença de aldicarbe nas águas, o risco de contaminação pode se tornar significativo. A legislação da Comunidade Econômica Européia (CEE) estabelece valores mais rigorosos. A Diretiva No 98/83/ECC estabelece concentrações máximas de 0,1 $\mu \mathrm{g} . \mathrm{L}^{-1}$ para qualquer pesticida e de $0,5 \mu \mathrm{g} . \mathrm{L}^{-1}$ para o caso de misturas de compostos em águas destinadas ao consumo humano (STROSSER et al., 1999).

Embora as concentrações de aldicarbe no ambiente se encontrem abaixo das que possam causar toxicidade aguda em seres humanos, a capacidade de formação de compostos mutagênicos (N-nitroso-carbamatos), sob condições encontradas no intestino humano, faz com que este composto apresente risco potencial à saúde (ELESPURU et al., 1974; RICKARD; DOROUGH, 1984). 
É importante destacar que nem sempre alguns poluentes podem ser detectados por razões que vão desde a sua rápida degradação no ambiente (com a possibilidade de geração de metabólitos de toxicidade igual ou superior) à impossibilidade de análise devido às dificuldades apresentadas na obtenção de seu padrão analítico.

\subsubsection{Degradação biológica e metabólitos}

Uma possível solução para problemas de contaminação ambiental é a biodegradação através de microrganismos. É reconhecido que aplicações freqüentes de agrotóxicos, incluindo os carbamatos, podem resultar em aumento da concentração ou adaptação de microrganismos capazes de degradá-los via mecanismos como indução enzimática, mutação ou transferência genética, aumentando conseqüentemente a velocidade de biodegradação (MILES; DELFINO, 1984; KAZUMI; CAPONE, 1995; SMELT et al., 1996). Por meio de técnicas de biorremediação, procura-se explorar a diversidade genética e versatilidade metabólica dos microrganismos com a finalidade de permitir a transformação dos contaminantes em produtos menos tóxicos que podem ser integrados nos ciclos biogeoquímicos naturais (UETA et al., 1999).

Embora seja conhecida a importância das bactérias no aumento da velocidade de degradação de compostos orgânicos, poucos estudos têm investigado a utilização do aldicarbe por microrganismos que ocorrem naturalmente, principalmente na ausência de oxigênio (KAZUMI; CAPONE, 1995; VINK e VAN DER ZEE, 1997).

Sob ação microbiológica, a degradação do aldicarbe pode se realizar, primordialmente, em duas rotas primárias: oxidação do aldicarbe a sulfóxido de aldicarbe e, posteriormente, a sulfona de aldicarbe e hidrólise do aldicarbe e seus resíduos oxidados às oximas correspondentes (ANDRAWES; BAGLEY; HERRET, 1971; OU; EDVARDSSON; RAO, 1985; OU et al., 1985).

A Figura 3.1, adaptada de Jackson, Mutch e Priddle (1990), mostra as vias de transformações do aldicarbe em condições aeróbias e anóxicas que usualmente ocorrem em plantas, animais, sedimentos e solos.

Kiene e Capone (1986) observaram que a metanogênese foi estimulada pela presença de aldicarbe em sedimentos marinhos e de aqüíferos ricos em material orgânico. O estímulo foi devido à presença de microrganismos e proporcional à quantidade de aldicarbe. A molécula de aldicarbe pode ser fonte de precursores imediatos do metano, o grupo S-metil e o grupo N-metil. O grupo S-metil é similar à metionina, metilcarptanos e dimetil sulfeto. $\mathrm{O}$ 
grupo N-metil é liberado como metilamina (MA) na hidrólise, podendo servir de substrato para algumas espécies de metanogênicas (HIPPE et al., 1979) e suportar a metanogênese na presença de concentrações elevadas de sulfato (KING; KLUG; LOVLEY, 1983; OREMLAND; MARSH; POLCIM, 1982). Entretanto, Kiene e Capone (1986) verificaram que, utilizando carbono radiomarcado $\left({ }^{14} \mathrm{C}\right)$ no grupo S-metil, não houve geração de ${ }^{14} \mathrm{CH}_{4}$, embora houvesse ocorrido estímulo da metanogênese. Para avaliar o grupo N-metil, os autores observaram a produção de metilamina e metano na presença de aldicarbe, ácido bromo-etano sulfônico (BES - inibidor da metanogênese) e dos dois compostos em conjunto. Na presença de aldicarbe, houve estímulo à formação de metano e, formação e posterior consumo de MA. Na presença do BES, não houve formação de metano e MA. Entretanto, na presença de aldicarbe e BES, não houve formação de metano, mas houve formação e consumo de MA. De acordo com os autores, este resultado foi coerente com o encontrado por King, Klug e Lovley (1983), que determinaram que a MA pode ser metabolizada a $\mathrm{CO}_{2}$ pelas bactérias redutoras de sulfato (BRS).

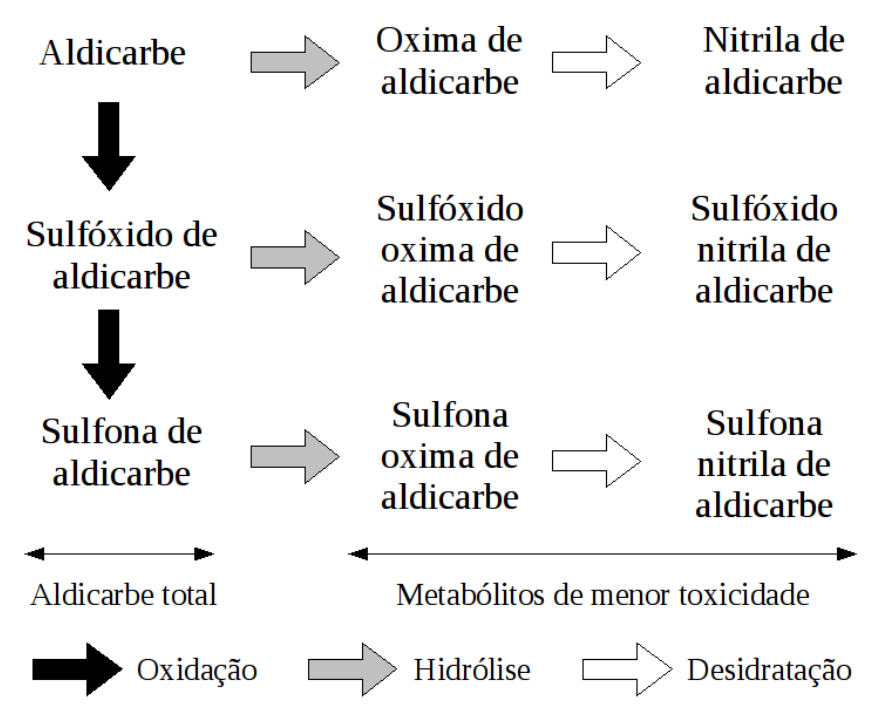

Figura 3.1. Vias de degradação do aldicarbe em plantas, animais, sedimentos e solos.

Kazumi e Capone (1995) estudaram o potencial de degradação do aldicarbe na presença e na ausência de oxigênio em sedimentos de locais de pouca e de grande profundidade. Em condições aeróbias, houve maior formação de sulfóxido e sulfona de aldicarbe, enquanto que, na ausência de oxigênio, a hidrólise do aldicarbe foi a rota predominante, com oxima de aldicarbe e sulfóxido oxima de aldicarbe (e presumivelmente metilamina) formando os principais resíduos da transformação do aldicarbe. Na presença de oxigênio, estes produtos de hidrólise não foram formados. 
Vink e Van Der Zee (1997) observaram que, em sedimentos lacustres e em condições anaeróbias, a velocidade de transformação do aldicarbe foi superior às encontradas em condições aeróbias. Observou-se, também, a não formação dos produtos de oxidação sulfóxido e sulfona de aldicarbe em condições anaeróbias.

Portanto, diferentes condições de potencial redox não afetam somente a velocidade de transformação do composto principal, mas também os tipos e concentrações dos produtos de degradação (VINK; VAN DER ZEE, 1997). Já que a hidrólise do aldicarbe produz resíduos que não são tão tóxicos quanto os compostos primários, a via de transformação torna-se importante levando-se em conta a sua atuação no ambiente (KAZUMI; CAPONE, 1995).

É conhecido o potencial microbiano de degradação de contaminantes orgânicos na presença de aceptores de elétrons alternativos (nitrato e sulfato, entre outros) e de substratos orgânicos (acetato, etanol, butirato, propionato e formiato, entre outros), processo este conhecido como co-metabolismo. Assim, avaliar alternativas de degradação nestas condições torna-se ferramenta importante de otimização em processos de biorremediação.

Kazumi e Capone (1995) também avaliaram a degradação do aldicarbe em condições anóxicas, ou seja, na presença de nitrato, e na presença de outros substratos orgânicos (acetato e glicose). Em condições anóxicas, as velocidades de transformação do aldicarbe foram muito superiores tanto nos sedimentos mais profundos quanto nos sedimentos menos profundos quando comparados às condições na ausência de nitrato. Entretanto, em sedimentos de maior profundidade (contendo somente microorganismos anaeróbios), a velocidade foi muito superior. Segundo os autores, os resultados obtidos indicaram que condições anóxicas promoveram a transformação do aldicarbe e sugerem que microorganismos anaeróbios ou facultativos são mais importantes que bactérias aeróbias durante o processo ou que diferentes tipos de bactérias estejam envolvidas em zonas de diferentes condições de oxidação. Na presença de substratos orgânicos alternativos, observou-se que, em amostras contendo acetato, houve maior assimilação e, conseqüentemente, maiores velocidades de degradação do aldicarbe do que em outras amostras (contendo glicose, nitrato e, glicose e nitrato). Outra observação foi que, na transformação do aldicarbe, as arquéias metanogênicas são mais importantes do que as bactérias redutoras de sulfato.

A rápida conversão do aldicarbe a sulfóxido de aldicarbe e posteriormente a sulfona de aldicarbe faz com que os mesmos coexistam em amostras ambientais. Esta característica se torna importante se for considerado que a presença do aldicarbe e de seus metabólitos em conjunto conduziram a um aumento de $50 \%$ na toxicidade a microrganismos quando considerados os compostos individuais (CANNA; PIERA, 1994). 


\subsubsection{Tecnologias empregadas na degradação/remoção de aldicarbe em águas}

Como o aldicarbe é rapidamente degradado aos metabólitos sulfóxido e sulfona de aldicarbe no ambiente e os três compostos possuem toxicidade semelhante, deve-se utilizar tecnologia apropriada para remover todos os três compostos eficientemente.

\subsubsection{Processos BIOLÓGICOS}

Poucos estudos foram realizados para se avaliar o emprego de mecanismos biológicos no processo de remoção de aldicarbe, notadamente em condições anaeróbias.

Asgari et al. (1995) avaliaram o enriquecimento em placas de culturas que sejam capazes de utilizar o aldicarbe como única fonte de carbono e energia. O enriquecimento foi feito a partir de amostras de solo com histórico de aplicação de Temik na cultura de algodão. Embora as culturas tenham crescido em meio contendo aldicarbe extraído do produto comercial como única fonte de carbono, os autores não detectaram mudanças na concentração do mesmo. Então, os autores concluíram que o Temik talvez tivesse em sua composição alguma fonte de carbono facilmente utilizável, o que interferiu no consumo de aldicarbe. Essas suposições foram confirmadas pelas análises cromatográficas. Assim, o enriquecimento foi repetido após os procedimentos para purificação do Temik a fim de se obter somente aldicarbe do produto comercial. O uso de aldicarbe purificado ocasionou aumento no tempo de aparecimento das colônias, de 24 a 72 horas para 48 a 114 horas. As maiores velocidades de consumo de aldicarbe purificado foram atingidas na concentração de 200 mg. $\mathrm{L}^{-1}$ (dados não apresentados) em $30^{\circ} \mathrm{C}$ e pH de 7,5. Além disso, o consórcio microbiano isolado foi capaz de tolerar concentrações de até $1000 \mathrm{mg} . \mathrm{L}^{-1}$, no entanto, com baixas velocidades de utilização de aldicarbe.

Kök et al. (1999) avaliaram a biodegradação aeróbia do aldicarbe em um reator de leito empacotado com Methylosinus imobilizada em microesferas de carboximetilcelulose. A bactéria foi isolada de solo com histórico de aplicação de aldicarbe. O reator, de 42,4 mL de volume, foi operado a $30 \pm 0,2{ }^{\circ} \mathrm{C}$. O efeito do aumento da concentração de aldicarbe na sua velocidade de degradação foi determinado pela variação da concentração de 50 a $800 \mathrm{mg} . \mathrm{L}^{-1}$ no tempo de detenção hidráulica de 2,2 horas. A velocidade de conversão de aldicarbe atingiu o valor máximo de $50 \mathrm{mg} \cdot \mathrm{L}^{-1} \cdot \mathrm{h}^{-1}$, para a concentração de $400 \mathrm{mg} \cdot \mathrm{L}^{-1}$, O aumento da concentração a partir desse ponto causou redução brusca da velocidade de conversão. 
Entretanto, a conversão de aldicarbe permaneceu estável, com um valor máximo de 17,5\%. O efeito do tempo de detenção hidráulica na eficiência de degradação foi determinado pela variação do TDH de 0,6 a 5 horas para a concentração de 100 mg. $\mathrm{L}^{-1}$. A redução do TDH ocasionou incremento da conversão de aldicarbe, principalmente devido à redução da resistência à transferência de massa externa. A conversão máxima atingida foi de aproximadamente 10\%. O reator também foi operado em batelada na concentração de 100 mg. $L^{-1}$ por meio da recirculação da fase líquida. Em 24 horas de ensaio, aproximadamente 50\% da concentração inicial foi convertida, atingindo 80\% em 72 horas e 100\% em 96 horas. Apesar de os autores especificarem na descrição do método analítico a avaliação de sulfóxido e sulfona de aldicarbe, não há nenhum resultado experimental ou observação no decorrer do trabalho.

Rose et al. (2006) avaliaram a remoção de agrotóxicos pelo sistema de alagados construídos em escala piloto (composto por uma lagoa não vegetada e uma vegetada, dispostas em série) em uma fazenda cuja atividade principal era o plantio de algodão. O afluente foi proveniente dos tubos de drenagem agrícola de uma área irrigada. A cada evento de irrigação o excesso de água era encaminhado ao sistema. Com o enchimento total, a alimentação era interrompida até o próximo evento de irrigação (a cada duas semanas). Após a incubação, o sistema era esvaziado. No primeiro período de avaliação (2002), foi detectada a presença de aldicarbe nas amostras do afluente após aplicação no campo, mesmo após 50 dias (em concentrações inferiores a $90 \mu$ g. $\mathrm{L}^{-1}$ ). Neste período, a remoção de aldicarbe variou

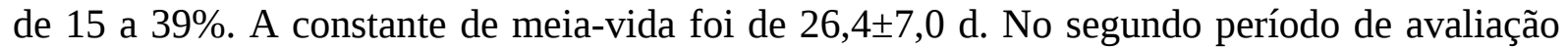
(2003), o aldicarbe foi detectado em concentrações inferiores a $7 \mu \mathrm{g} . \mathrm{L}^{-1}$. Entretanto, neste ano não houve aplicação de aldicarbe na área de estudo, como observado anteriormente. A constante de meia-vida foi menor, de $6,3 \pm 0,3$ d. Não houve diferença entre a lagoa não vegetada e a lagoa vegetada, sendo este um indício de que as espécies vegetais presentes não tiveram importância significativa no processo de remediação de aldicarbe. Assim, não houve evidências claras de qual mecanismo foi responsável por sua remoção. Ademais, os autores não avaliaram a formação de sulfóxido e sulfona de aldicarbe justificando que, em condições anóxicas/anaeróbias supostamente ocorridas no sistema, esses não são formados. Entretanto, recomendaram o monitoramento desses metabólitos bem como a avaliação da concentração de oxigênio dissolvido a fim de que essas premissas sejam confirmadas. 


\subsubsection{OUtRas TECNOLOGias}

A adsorção em carvão ativado granular se mostrou eficiente na remoção de 200 a $1000 \mu \mathrm{g} . \mathrm{L}^{-1}$ da mistura dos três compostos na proporção 10:45:45 para aldicarbe, sulfóxido e sulfona de aldicarbe, respectivamente (UNION CARBIDE, 1979). Ainda, segundo a Union Carbide (1979), a utilização da cloração também foi investigada como alternativa de remoção de aldicarbe da água potável, ocorrendo a conversão total a sulfóxido e sulfona de aldicarbe em minutos e posteriormente a compostos não identificados. Portanto, a aplicação desta tecnologia é função da toxicidade apresentada por estes compostos.

A aeração (“air stripping”), não tem sido eficiente na remoção do aldicarbe de água potável (BARON; MERRIAM, 1988).

\subsubsection{Métodos de detecção do aldicarbe e metabólitos}

Aldicarbe e seus produtos de oxidação podem ser determinados em termos de suas nitrilas derivadas por cromatografia gasosa por meio de detector nitrogênio-fósforo (ZHONG; LEMLEY; SPALIK, 1984). A cromatografia gasosa se mostra difícil porque (a) alguns desses compostos são termicamente instáveis, (b) amostras devem ser extraídas e tratadas antes da análise e (c) a especiação dos metabólitos requer uma etapa de clean-up por cromatografia líqüida (MILES; DELFINO, 1984). A determinação de carbamatos por eletroforese capilar (JANDIK; BONN, 1993) e cromatografia eletrocinética capilar (ARRAÉZ-ROMÁN et al., 2004) também tem sido investigada.

A detecção do aldicarbe também pode ser determinada por cromatografia líqüida de alta eficiência (HPLC) (WHO, 1991). HPLC proporciona um método simples e rápido para a determinação do aldicarbe e seus metabólitos (MILES; DELFINO, 1984).

O método 531.1 da Environmental Protection Agency (EPA) é aplicável à determinação de N-carbamoil-oximas e N-metilcarbamatos em águas subterrâneas e de abastecimento. Esse método emprega a análise direta de amostra de água com separação por HPLC e derivatização pós-coluna à compostos detectados com detector de fluorescência (MUNCH, 1995). A amostra filtrada $(400 \mu \mathrm{L})$ é injetada em coluna de fase reversa para HPLC. A separação dos analitos é obtida pelo emprego de metanol e água na fase móvel em gradiente de eluição. Após a eluição, os analitos são hidrolisados com solução de 0,05 N de hidróxido de sódio a $95^{\circ} \mathrm{C}$. A metilamina formada reage com o-ftaldeído (OPA) e 2mercaptoetanol para formar um derivado fortemente fluorescente o qual é medido pelo 
detector de fluorescência.

Miles e Delfino (1984) desenvolveram um método para determinar o aldicarbe e seus metabólitos por HPLC com detector de ultravioleta (UV) $(\lambda=200 \mathrm{~nm})$ em amostras de água subterrânea sem pré-tratamento. Acetonitrila e água foram utilizadas como fase móvel em duas corridas isocráticas (12:88/40:60) para separar todos compostos de aldicarbe (aldicarbe, sulfóxido de aldicarbe, sulfona de aldicarbe e suas respectivas nitrilas e oximas). Esse protocolo foi adaptado por Kazumi e Capone (1995) por meio de gradiente de eluição em uma simples corrida cromatográfica e empregando o metomil como padrão interno.

Em sistemas HPLC, diferentes detectores têm sido avaliados, como espectrometria de massas por eletro-spray (ES-MS) (DI CORCIA et al., 2000) e espectrometria de massas por ionização química sob pressão atmosférica (APCI-MS) (NUNES et al., 2000). Embora a precisão aumente com o uso dessas técnicas, o custo do equipamento é significativo.

Usualmente os métodos envolvem extração ou outras etapas de preparação da amostra (extração em fase sólida (SPE) ( JANDIK; BONN, 1993; DI CORCIA et al., 2000; NUNES et al., 2000) ou extração em fase líquida (LLE) (NUNES et al., 2000)) que podem causar resultados duvidosos e consomem tempo de análise. Então, o uso de métodos que não requerem a preparação da amostra aumentam a precisão da determinação (MILES; DELFINO, 1984). Além disso, quando o método não usa qualquer derivatização, os erros experimentais são reduzidos.

\subsection{Reator anaeróbio horizontal de leito fixo (RAHLF)}

O reator anaeróbio horizontal de leito fixo (RAHLF) foi proposto por Zaiat et al. (1994) em escala de bancada. A primeira avaliação desse reator foi feita por Foresti et al. (1995) quando verificou seu desempenho no tratamento de água residuária de indústria de papel reciclado. Posteriormente, avaliou-se o seu emprego para o tratamento de águas residuárias sintéticas simples, à base de glicose (ZAIAT et al., 1997), de águas residuárias complexas, contendo proteínas, carboidratos e lipídios (SARTI et al., 2001) e de esgoto sanitários (ZAIAT et. al., 2001). Em todos essas trabalhos, empregando-se espuma de poliuretano como meio suporte, foram observadas elevadas eficiências de conversão de matéria orgânica, demostrando seu potencial como tecnologia de tratamento de efluentes.

O baixo grau de mistura longitudinal desse reator proporcionou seu uso para propósitos específicos, como, por exemplo, águas residuárias contendo compostos tóxicos. 
Nesse contexto, os estudos do desempenho do RAHLF na remoção de compostos tóxicos ou recalcitrantes foram iniciados, submetendo o sistema à diferentes substâncias e condições de oxidação.

Bolanos et al. (2001) verificaram o potencial do RAHLF na degradação de fenol empregando-se TDH de 12 horas. O reator operou inicialmente com substrato sintético com DQO de 1028 mg.L ${ }^{-1}$ alcançando eficiência de conversão de 98\%. Posteriormente o substrato foi composto por fenol empregando-se concentrações crescentes de 50 a 1200 mg.L ${ }^{-1}$. Em todas concentrações avaliadas observou-se elevadas eficiências de remoção de aproximadamente 99\%.

Oliveira et. al. (2004) experimentaram o RAHLF no tratamento de água residuária contendo formaldeído em concentrações afluentes de 23,2 a 1158,6 mg Hсо $_{\text {. }}{ }^{-1}$. A eficiência de remoção de formaldeído e DQO foi de 99,7 e 92\%, respectivamente.

De Nardi et al. (2005) avaliaram dois RAHLFs na remoção de gasolina de aqüíferos subterrâneos contaminados. O primeiro reator foi inicialmente operado com substrato orgânico contendo proteína, carboidrato e benzeno, tolueno, etilbenzeno e xileno (BTEX), solubilizados em etanol. A concentração de cada composto do BTEX variou de 3 a 15 mg.L $\mathrm{L}^{-1}$. Posteriormente a solução de BTEX em etanol foi utilizada como fonte de carbono. O tempo de detenção hidráulica foi de 11,4 h e a temperatura foi de $30 \pm 1^{\circ} \mathrm{C}$. A eficiência de remoção de DQO foi de aproximadamente 96\%, enquanto que a remoção de BTEX variou de 75 a 99\%. O segundo reator foi empregado de modo a simular a remoção em condições de campo. O reator foi alimentado com uma mistura de água e gasolina comercial, sem etilbenzeno. A concentração de cada componente do BTX (benzeno, tolueno e m-xileno) foi gradualmente aumentada até $15 \mathrm{mg} . \mathrm{L}^{-1}$. O TDH foi de 20 horas e a temperatura de $25 \pm 1^{\circ} \mathrm{C}$. O TDH foi gradualmente reduzido até 8 horas. As maiores eficiências de remoção foram alcançadas para TDHs superiores a 12 horas, com 99 e 95\% para DQO e BTX, respectivamente.

Gusmão et al. (2006) testaram a performance do RAHLF, contendo biomassa desnitrificante, na remoção de BTEX e etanol. O reator foi alimentado com hidrocarbonetos separadamente (benzeno, 13,8, 15,4 e 26,5 mg. $\mathrm{L}^{-1}$; tolueno, 30,8 mg. $\mathrm{L}^{-1}$; etilbenzeno, 33,3 mg. $\mathrm{L}^{-1}$ e xileno, 32,1 mg. $\mathrm{L}^{-1}$ ) e uma mistura de BTEX com aproximadamente 5 mg. $\mathrm{L}^{-1}$ de cada hidrocarbono, dissolvidos em solução com etanol. A remoção de matéria orgânica foi de 95\% para benzeno e tolueno e aproximadamente 76\% para o etilbenzeno, m-xileno e mistura de BTEX. A eficiência de remoção de hidrocarbonetos foi de $99 \%$ para a concentração inicial de 26,5 mg. $\mathrm{L}^{-1}$ de benzeno, 30,8 mg. $\mathrm{L}^{-1}$ de tolueno, 32,1 mg. $\mathrm{L}^{-1}$ de m-xileno, 33,3 mg. $\mathrm{L}^{-1}$ de etilbenzeno e 26,5 mg. $\mathrm{L}^{-1}$ de BTEX. 
Saia et al. (2007) estudaram a degradação do pentaclorofenol (PCP) no RAHLF inoculado com sedimentos provenientes do estuário de Santos - São Vicente previamente enriquecidos em condições metanogênicas e halofílicas. Utilizando o TDH de 18 horas, constatou-se eficiências de remoção de 70 a 100\% para DQO e de 99\% para o PCP.

Baraldi et al. (2008) avaliaram o tratamento biológico do PCP e metanol como fontes únicas de carbono. O meio suporte foi espuma de poliuretano que foram colonizadas por biomassa não adaptada. A concentração de PCP variou de 2 a 13 mg.L-1. Foram verificadas eficiências de remoção de 97 e 99\% para DQO e PCP, respectivamente.

\subsection{Considerações finais}

Embora a maior parte dos trabalhos sobre aldicarbe tenha sido realizada na década de 80 e 90, a preocupação com esse composto se mostra atual em virtude da ampla discussão sobre sua proibição em vários países em função do risco que seu uso pode representar. E esse risco pode ser elevado no caso de uso indevido e/ou incorreto ou quando há ocorrência de acidentes durante seu processo de produção ou utilização. Assim, o estudo de seu comportamento em determinadas condições pode ser fundamental para a tomada de decisão em situações emergenciais.

A potenciabilidade de degradação biológica do aldicarbe foi exposta pela análise dos resultados encontrados tanto em sedimentos quanto em amostras de solo. Como o aldicarbe apresenta diferentes rotas de degradação de acordo com as condições ambientais existentes, é possível a obtenção de diferentes produtos de degradação através da manipulação das variáveis do processo, como potencial redox e aceptores de elétrons alternativos, por exemplo. Assim, o estabelecimento de condições anaeróbias e anóxicas permite a redução da toxicidade de aqüíferos contaminados, já que a concentração aguda de seus metabólitos é menor.

A otimização do processo de biorremediação por meio do estudo de diferentes condições de degradação vem ao encontro com a necessidade de reatores biológicos mais eficientes e mais compactos que resultem em menores custos de implantação e operação. A obtenção de parâmetros cinéticos e de outros parâmetros possibilita, além de um melhor entendimento dos processos envolvidos, a ampliação mais segura da escala dos reatores, de sistemas em escala laboratorial para sistemas em escala plena.

Como foram poucos os relatos do emprego de biorreatores na degradação do aldicarbe, o estudo apresenta caráter inovador ao fazer uso desta ferramenta, principalmente 
em condições de ausência de oxigênio. Os resultados promissores do biorreator anaeróbio horizontal de leito fixo (RAHLF) na degradação de substâncias tóxicas fazem com que este reator, devido às suas características, se torne uma importante alternativa em processo de descontaminação de ambientes.

\section{MATERIAL E MÉTODOS}

Para se avaliar a degradação do aldicarbe em condições anaeróbias, foi adotado o protocolo experimental ilustrado na Figura 4.1.
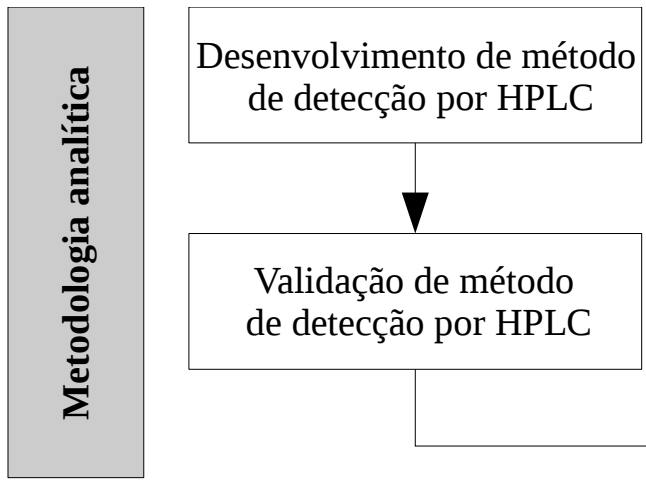
de detecção por HPLC

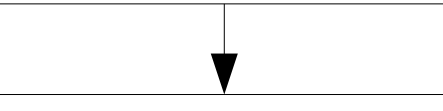

Validação de método de detecção por HPLC
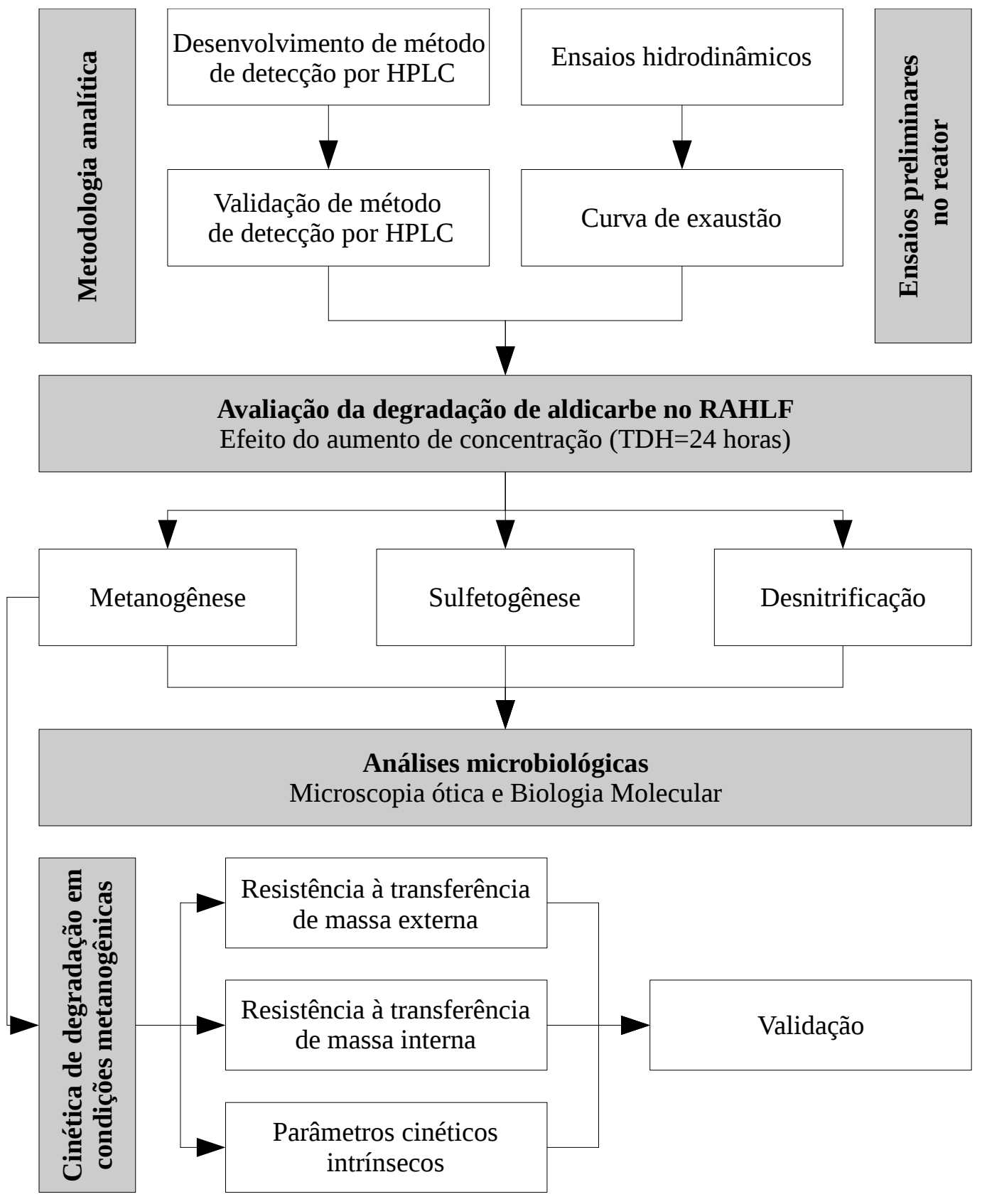

Figura 4.1. Protocolo experimental desenvolvido. 


\subsection{Desenvolvimento de método de detecção de aldicarbe, sulfóxido de aldicarbe e sulfona de aldicarbe por cromatografia líquida de alta eficiência (HPLC)}

\subsubsection{Instrumentação e condições analíticas}

Foi utilizada cromatografia líquida de alta eficiência (HPLC) em cromatógrafo Shimadzu $^{\circledR}$, equipado com bomba LC-10ADVP, válvula FCV-10ALVP, detector ultravioleta (UV) com arranjo de diodos (SPD-M10 AVP), controlador SCL-10AVP, injetor Rheodyne ${ }^{\circledR}$ (100 $\mu \mathrm{L}$ loop) e coluna Agilent Zorbax ODS $^{\circledR}$ C-18 (mesh size: $5 \mu \mathrm{m}$; tamanho: $25 \mathrm{~cm}$; diâmetro interno: 4,6 mm). O aldicarbe e seus metabólitos foram separados pelo emprego de um gradiente linear de eluição utilizando água e acetonitrila como fase móvel (Tabela 4.1). A vazão foi de $1,2 \mathrm{~mL} \cdot \mathrm{min}^{-1}$ e a temperatura do forno foi de $40{ }^{\circ} \mathrm{C}$. O detector de UV foi utilizado em $\lambda=210 \mathrm{~nm}$. O metomil foi utilizado como padrão interno. Este protocolo foi uma modificação do procedimento desenvolvido por Miles e Delfino (1984) e Kazumi e Capone (1995).

Tabela 4.1 - Gradiente de eluição utilizado para determinar aldicarbe e seus metabólitos por HPLC.

\begin{tabular}{ccc}
\hline Tempo (min) & \% Solvente A & \% Solvente B \\
\hline 0 & 80 & 20 \\
4 & 60 & 40 \\
13 & 45 & 55 \\
15 & 80 & 20 \\
22 & STOP & STOP \\
\hline
\end{tabular}

Solvente A: Água; Solvente B: Acetonitrila.

\subsubsection{Padrões cromatográficos e solventes}

Os padrões cromatográficos aldicarbe (99\% de pureza), sulfóxido de aldicarbe (99\% de pureza), sulfona de aldicarbe (99\% de pureza) e metomil (95\% de pureza) foram obtidos de Radian International ${ }^{\circledR}$, Ultra Scientific ${ }^{\circledR}$, ChemService ${ }^{\circledR}$ e AccuStandard $^{\circledR}$, respectivamente. A determinação das oximas e nitrilas (Figura 3.1) não foi possível em função da dificuldade em se adquirir os padrões analíticos bem como no custo elevado da síntese dos mesmos. 
A acetonitrila foi obtida de JT Baker ${ }^{\circledR}$ (grau HPLC) e a água foi ultrapurificada em sistema Millipore MilliQ ${ }^{\circledR}$.

\subsubsection{Preparação das amostras}

As amostras foram preparadas em balões volumétricos $(5 \mathrm{~mL})$ pela adição de $200 \mu \mathrm{L}$ de uma solução de metomil em água (115,2 mg. $\left.\mathrm{L}^{-1}\right)$ e pela diluição de diferentes volumes de amostras (2, 3 ou $4 \mathrm{~mL}$ ) em água ultrapurificada. Antes da injeção, as amostras foram filtradas em filtro Millipore ${ }^{\circledR}$ de $0,2 \mu \mathrm{L}$ de abertura.

\subsubsection{Validação do método}

O método foi validado pela determinação de sua linearidade, precisão, precisão instrumental e limite de detecção (LOD) e quantificação (LOQ) de acordo com método proposto anteriormente (DUARTE et al., 2006). As curvas-padrão de calibração foram obtidas pela diluição de três soluções com os padrões de referência com três replicatas cada. A diluição foi realizada em água ultrapurificada e meio basal (ANGELIDAKI; PETERSEN; AHRING, 1990) (Tabela 4.2) para obter as concentrações apresentadas na Tabela 4.3

\section{Linearidade}

A linearidade da resposta do detector para os padrões preparados foi avaliada por meio da análise da regressão linear, relacionando-se as quantidades de cada padrão, medida em mg. $\mathrm{L}^{-1}$, e o fator de resposta (FR) (área do pico correspondente/área de metomil). A avaliação da significância estatística da regressão foi feita realizando-se a Análise de Variância (ANOVA) (Tabela 4.4) e, posteriormente, pelos testes de ajuste ao modelo linear (ALM), validade da regressão (VR) e eficiência da regressão (ER) (Tabela 4.5) (CHUI; ZUCHINI; LICHTIG, 2001; CHUI, 2007). 
Tabela 4.2 - Composição do meio sintético.

\begin{tabular}{|c|c|c|c|}
\hline Componente & $\mathrm{C}_{\text {estoque }}{ }^{\mathrm{a}}\left(\mathrm{g} \cdot \mathrm{L}^{-1}\right)$ & $\mathrm{V}^{\mathrm{b}}(\mathrm{mL})$ & $\mathrm{C}_{\text {soluçẫo }}^{\mathrm{c}}\left(\mathrm{mg} \cdot \mathrm{L}^{-1}\right)$ \\
\hline \multicolumn{4}{|l|}{$\begin{array}{l}\text { 1. Meio basal } \\
\text { (ANGELIDAKI; PETERSEN; AHRING, 1990) }\end{array}$} \\
\hline \multicolumn{4}{|l|}{ Solução A } \\
\hline $\mathrm{NH}_{4} \mathrm{Cl}$ & 100 & \multirow{4}{*}{10} & 1000 \\
\hline $\mathrm{NaCl}$ & 10 & & 100 \\
\hline $\mathrm{MgCl}_{2} \cdot 6 \mathrm{H}_{2} \mathrm{O}$ & 10 & & 100 \\
\hline $\mathrm{CaCl}_{2} \cdot 2 \mathrm{H}_{2} \mathrm{O}$ & 5 & & 50 \\
\hline \multicolumn{4}{|l|}{ Solução B } \\
\hline $\mathrm{K}_{2} \mathrm{HPO}_{4} \cdot 3 \mathrm{H}_{2} \mathrm{O}$ & 200 & 2 & 400 \\
\hline \multicolumn{4}{|l|}{ Solução C (metais traços e selenito) } \\
\hline $\mathrm{FeCl}_{2} \cdot 4 \mathrm{H}_{2} \mathrm{O}$ & 2 & \multirow{12}{*}{1} & 2 \\
\hline $\mathrm{H}_{3} \mathrm{BO}_{3}$ & 0,05 & & 0,05 \\
\hline $\mathrm{ZnCl}_{2}$ & 0,05 & & 0,05 \\
\hline $\mathrm{CuCl}_{2} \cdot 2 \mathrm{H}_{2} \mathrm{O}$ & 0,038 & & 0,038 \\
\hline $\mathrm{MnCl}_{2} \cdot 4 \mathrm{H}_{2} \mathrm{O}$ & 0,05 & & 0,05 \\
\hline$\left(\mathrm{NH}_{4}\right)_{6} \mathrm{Mo}_{7} \mathrm{O}_{24} \cdot 4 \mathrm{H}_{2} \mathrm{O}$ & 0,05 & & 0,05 \\
\hline $\mathrm{AlCl}_{3}$ & 0,05 & & 0,05 \\
\hline $\mathrm{CoCl}_{2} \cdot 6 \mathrm{H}_{2} \mathrm{O}$ & 0,05 & & 0,05 \\
\hline $\mathrm{NiCl}_{2} \cdot 6 \mathrm{H}_{2} \mathrm{O}$ & 0,092 & & 0,092 \\
\hline EDTA & 0,5 & & 0,5 \\
\hline $\mathrm{HCl}$ concentrado & $1 \mathrm{~mL}$ & & $1 \mathrm{~mL} \cdot \mathrm{L}^{-1}$ \\
\hline $\mathrm{Na}_{2} \mathrm{SeO}_{3} \cdot 5 \mathrm{H}_{2} \mathrm{O}$ & 0,1 & & 0,1 \\
\hline \multicolumn{4}{|l|}{$\frac{\text { 2. Vitaminas }}{\text { (WOLIN; WOLIN; WOLFE, 1963) }}$} \\
\hline Ácido fólico & 0,010 & \multirow{10}{*}{2} & 0,020 \\
\hline Ácido p-aminobenzóico & 0,025 & & 0,050 \\
\hline Ácido pantotênico & 0,025 & & 0,050 \\
\hline Ácido tióico & 0,025 & & 0,050 \\
\hline Biotina & 0,010 & & 0,020 \\
\hline Vitamina B1 (Tiamina) & 0,025 & & 0,050 \\
\hline Vitamina B2 (Riboflavina) & 0,025 & & 0,050 \\
\hline Vitamina B5 (Nicotinamida) & 0,025 & & 0,050 \\
\hline Vitamina B6 (Piridoxina) & 0,050 & & 0,100 \\
\hline Vitamina B12 (Cianocobolamina) & 0,0001 & & 0,0002 \\
\hline 3. Fonte de carbono $\left(\right.$ Temik $\left.^{\circledR}\right)$ & - & - & Variável \\
\hline 4. Solução tampão $\left(\mathrm{NaHCO}_{3}\right)$ & - & - & 500 \\
\hline 5. Aceptor de elétrons & - & - & \\
\hline $\mathrm{Na}_{2} \mathrm{SO}_{4}$ (Reator Sulfetogênico) & - & - & Variável \\
\hline $\mathrm{NaNO}_{3}$ (Reator Desnitrificante) & - & - & Variável \\
\hline
\end{tabular}

\footnotetext{
${ }^{a}$ Concentração na solução estoque

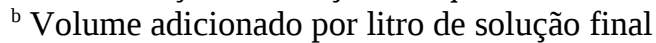

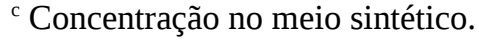


Tabela 4.3 - Concentrações dos analitos utilizados nas curvas de calibração.

\begin{tabular}{cc}
\hline Analito & Concentrações $\left(\mathrm{mg}^{-1} \mathrm{~L}^{-1}\right)$ \\
\hline Aldicarbe & 0,$49 ; 1,0 ; 2,49 ; 5,0 ; 10,0 ; 11,99 ; 15,0$. \\
Sulfóxido de aldicarbe & 0,$1 ; 0,3 ; 0,5 ; 1,0 ; 2,0 ; 4,0 ; 5,0$. \\
Sulfona de aldicarbe & 0,$1 ; 0,3 ; 0,5 ; 1,0 ; 2,0 ; 4,0 ; 5,0$. \\
\hline
\end{tabular}

Tabela 4.4 - ANOVA utilizada no Teste F.

\begin{tabular}{|c|c|c|c|c|}
\hline Fonte de variação & Soma dos quadrados & $\begin{array}{l}\text { Graus de } \\
\text { Liberdade }\end{array}$ & \multicolumn{2}{|c|}{$\begin{array}{c}\text { Média das Somas dos } \\
\text { Quadrados }\end{array}$} \\
\hline Total & $\mathrm{SQT}=\Sigma \Sigma \mathrm{y}_{\mathrm{ij}}^{2}$ & $\mathrm{n}$ & \multicolumn{2}{|c|}{$\mathrm{MQT}=\mathrm{SQT} / \mathrm{n}$} \\
\hline Correção (“b”) & $\mathrm{FC}=\mathrm{n} \cdot \mathrm{y}_{00}^{2}$ & 1 & \multicolumn{2}{|r|}{ FC } \\
\hline Total corrigido & $\mathrm{SQC}=\Sigma \Sigma\left(\mathrm{y}_{\mathrm{ij}}-\mathrm{y}_{00}\right)^{2}$ & $n-1$ & \multicolumn{2}{|c|}{$\mathrm{MQC}=\mathrm{SQC} /(\mathrm{n}-1)$} \\
\hline Devida à regressão (“a”) & $\mathrm{SQR}=\Sigma\left(\mathrm{y}_{\mathrm{i}}-\mathrm{y}_{00}\right)^{2}$ & 1 & \multicolumn{2}{|c|}{$\mathrm{MQR}=\mathrm{SQR}$} \\
\hline Residual & $\mathrm{SQE}=\Sigma \Sigma\left(\mathrm{y}_{\mathrm{ij}}-\mathrm{y}_{\mathrm{i}}\right)^{2}$ & $\mathrm{n}-2$ & \multicolumn{2}{|c|}{$\mathrm{MQE}=\mathrm{SQE} /(\mathrm{n}-2)$} \\
\hline Erro puro & $\mathrm{SQEP}=\Sigma \Sigma\left(\mathrm{y}_{\mathrm{ij}}-\mathrm{y}_{\mathrm{i} 0}\right)^{2}$ & $\mathrm{n}-\mathrm{m}_{\mathrm{i}}$ & \multicolumn{2}{|c|}{$\mathrm{MQEP}=\mathrm{SQEP} /\left(\mathrm{n}-\mathrm{m}_{\mathrm{i}}\right)$} \\
\hline Falta de ajuste & $\mathrm{SQL}=\Sigma\left(\mathrm{y}_{\mathrm{i}}-\mathrm{y}_{\mathrm{i} 0}\right)^{2}$ & $m_{i}-2$ & \multicolumn{2}{|c|}{$\mathrm{MQL}=\mathrm{SQL} /\left(\mathrm{m}_{\mathrm{i}}-2\right)$} \\
\hline \multicolumn{5}{|c|}{$\begin{array}{l}\mathrm{n}=\text { número total de medições; } \mathrm{m}_{\mathrm{i}}=\text { níveis de concentração }(7) ; \mathrm{y}_{\mathrm{ij}}=\text { resposta observada; } \mathrm{y}_{00}= \\
\text { média das respostas observadas; } \mathrm{y}_{\mathrm{i}}=\text { variável dependente predita pela equação linear; } \mathrm{y}_{\mathrm{i} 0}= \\
\text { média das replicadas do nível de concentração “i”; “i” - índice que se refere ao número de } \\
\text { variáveis independentes }(\mathrm{x}) \text {; “j” - índice que se refere às replicatas nos níveis x. Primeiro } \\
\text { somatório }(\Sigma) \text { diz respeito a } \mathrm{i}=1 \text { a } \mathrm{i}=\mathrm{m}_{\mathrm{i}} \text {. Segundo somatório }(\Sigma \Sigma) \text { in SQC, SQE e SQEP diz } \\
\text { respeito a } \mathrm{i}=1 \mathrm{a} \mathrm{j}=\mathrm{n}_{\mathrm{i}} \text {. }\end{array}$} \\
\hline \multicolumn{5}{|c|}{ Tabela 4.5 - Testes de linearidade e eficiência de regressão. } \\
\hline Teste & \multicolumn{2}{|c|}{$\mathrm{F}_{\text {critico }}$} & btido & Condição \\
\hline Ajuste ao modelo linear ( & \multicolumn{2}{|c|}{$\mathrm{F}_{\mathrm{mi}-2 ; \mathrm{n}-\mathrm{mi} ; \alpha / 2}$} & MQEP & $\mathrm{F}_{\text {obtido }}<\mathrm{F}_{\text {critico }}$ \\
\hline Validade da regressão (V & \multicolumn{2}{|c|}{$\mathrm{F}_{1 ; \mathrm{n}-2 ; \alpha / 2}$} & /MQE & $\mathrm{F}_{\text {obtido }}>>\mathrm{F}_{\text {critico }}$ \\
\hline \multicolumn{5}{|c|}{ Eficiência da Regressão (ER) } \\
\hline \multicolumn{2}{|l|}{ Eficiência $\left(r^{2}\right)$} & \multicolumn{3}{|c|}{ SQR/SQC } \\
\hline \multicolumn{2}{|l|}{ Eficiência máxima $\left(\mathrm{r}_{\max }^{2}\right)$} & \multicolumn{3}{|c|}{ SQC/SQEP } \\
\hline
\end{tabular}

\subsubsection{Limite de deteç̧ão (LOD) e limite de quantificação (LOQ)}

O LOD e LOQ para cada padrão foram determinados a partir das curvas de calibração calculando-se a raiz quadrada do erro quadrático médio (RMSE) de acordo com as seguintes expressões (LEE, 2003):

$$
\begin{aligned}
& \mathrm{LOD}=(3 \cdot \mathrm{RMSE}) / m \\
& \mathrm{LOQ}=(10 \cdot \mathrm{RMSE}) / m
\end{aligned}
$$


Em que:

RMSE: $\quad$ raiz quadrada do erro quadrático médio.

m: $\quad$ inclinação da equação de regressão linear.

\subsubsection{Precisão}

A precisão do sistema foi expressa como o coeficiente de variação (CV \%) dos tempos de retenção de cada padrão, em diferentes concentrações (Tabela 4.3).

\subsubsection{Precisão instrumental}

A precisão instrumental (como coeficiente de variação, CV \%) foi estimada pelo tempo de retenção de dez injeções repetidas de solução padrão em substrato sintético com aldicarbe, sulfóxido de aldicarbe e sulfona de aldicarbe na concentração de 4 mg.L-1 .

\subsection{Ensaios preliminares no RAHLF}

\subsubsection{Hidrodinâmica em condições abióticas}

\subsubsection{REATOR ANAERÓBio HORIZONTAL DE LEITO FiXo (RAHLF)}

O reatores foram construídos em vidro de borosilicato, com volume total de $1995 \mathrm{~mL}$, volume de escoamento de $800 \mathrm{~mL}$, comprimento de $100 \mathrm{~cm}$, diâmetro de $5 \mathrm{~cm}$ e relação L/D = 20. Cada reator foi dotado de 5 pontos intermediários para amostragem e sistema coletor de gás. A alimentação foi realizada através de bomba peristáltica (Minipuls $3^{\circledR}$, Gilson ${ }^{\circledR}$ ). A manutenção da temperatura do sistema em $30 \pm 1^{\circ} \mathrm{C}$ foi possível por meio de um sistema de aquecimento inserido na câmara onde os biorreatores foram instalados. Esse sistema de

aquecimento foi composto de resistência e ventiladores, controlados por um sensor e controlador de temperatura da marca Fullgauge ${ }^{\circledR}$ modelo MT-511R. A representação esquemática do sistema pode ser vista na Figura 4.2. 


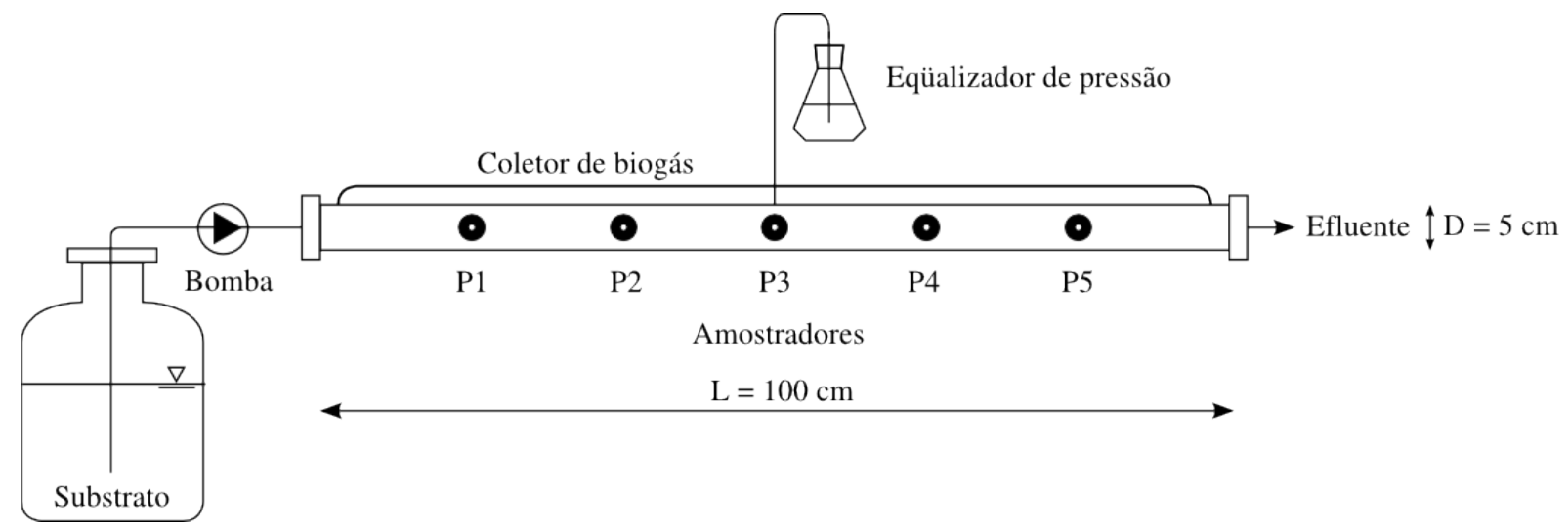

Figura 4.2. Representação esquemática do RAHLF em escala de bancada.

\subsubsection{MeIO SUPORTE}

O meio suporte foi espuma de poliuretano na forma de cubos de $5 \mathrm{~mm}$ de aresta, com densidade aparente de $23 \mathrm{~kg} \cdot \mathrm{m}^{-3}$, porosidade próxima a 95\% e raio de esfera equivalente $\left(\mathrm{R}_{\mathrm{eq}}\right)$ igual a 0,31, produzida sem adição de corantes ou aditivos pela empresa Colchões Guilherme, localizada na cidade de São Carlos, SP. Para cada reator foram adicionados 30 g de espuma seca.

\subsubsection{PROCEDIMENTO EXPERIMENTAL}

Para se determinar o regime de escoamento predominante nos reatores, foram realizados ensaios em condições abióticas (água destilada e espuma de poliuretano) utilizando-se a técnica estímulo-resposta com injeção do tipo degrau. Inicialmente foram avaliados diferentes traçadores, a saber: dextrana azul, eosina Y, rodamina Bt e cloreto de sódio $(\mathrm{NaCl})$. Entretanto, a eosina $\mathrm{Y}$ e a rodamina $\mathrm{Bt}$ não foram satisfatórias por adsorverem fortemente na espuma de poliuretano. As curvas normalizadas da concentração (Curvas F) de traçador para dextrana azul e cloreto de sódio foram semelhantes (Figura 4.3). Assim, por apresentar menor custo e ser de mais fácil detecção, adotou-se o cloreto de sódio nos ensaios posteriores. 


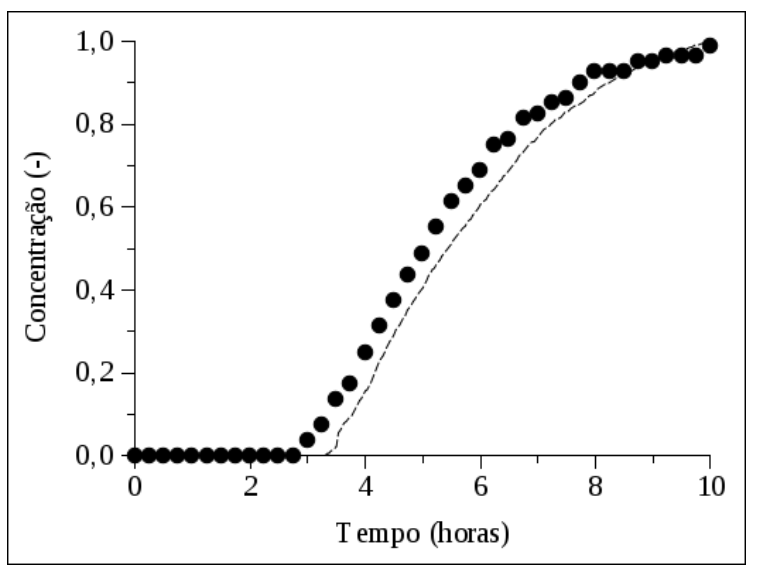

Figura 4.3. Curvas normalizadas da concentração de dextrana azul e cloreto de sódio.

[Notação: •, dextrana azul; ---, cloreto de sódio.]

Os tempos de detenção hidráulica teóricos $\left(\mathrm{TDH}_{\mathrm{t}}\right)$ testados foram de 3, 6, 8, 12, 16,18 e 24 horas, considerando volume útil teórico de 0,8 L do RAHLF (ZAIAT, 1996). A concentração de cloreto de sódio utilizado nos ensaios foi de $100 \mathrm{mg} . \mathrm{L}^{-1}$. O monitoramento do traçador foi realizado indiretamente pela variação da condutividade na fase líquida na saída do reator. O equipamento utilizado foi composto de uma sonda de condutividade Vernier ${ }^{\circledR}$ acoplada ao sistema de aquisição de dados CBL da Texas Instruments ${ }^{\circledR}$ e à calculadora TI-89 também da Texas Instruments ${ }^{\circledR}$. O uso deste equipamento permitiu a aquisição de 300 pontos experimentais ao longo do ensaio. O tempo de ensaio foi superior a três vezes o tempo de detenção hidráulica teórico. Todos ensaios foram realizados em duplicata.

\subsubsection{Avaliação do REgime de escoamento}

A partir da determinação dos resultados experimentais, efetuou-se a análise das condições predominantes do escoamento do reator de acordo com modelos analíticos de escoamento em meios porosos propostos por Levenspiel (1999) e por Danckwerts (1953).

\section{Levenspiel (1999)}

Para simplificar o tratamento matemático, derivou-se a curva F obtendo-se a Curva E. Assim, inicialmente ajustou-se a Curva F de cada ensaio à Sigmóide de Gompertz (Equação 4.3). Este ajuste se faz necessário, pois quando os dados experimentais são derivados diretamente, os resultados nem sempre são satisfatórios. Portanto, a partir dos parâmetros a, b e c determinados no ajuste em cada ensaio, obteve-se a Curva E (Equação 4.4) 


$$
C_{N}=F=a \times e^{-e^{-b \mid t-c)}}
$$

Em que:

$\mathrm{C}_{\mathrm{N}}$ : $\quad$ concentração normalizada de traçador (adimensional);

t: $\quad$ tempo (horas).

a, b, c: $\quad$ parâmetros de ajuste da Sigmóide de Gompertz.

$$
\frac{d C_{N}}{d t}=\frac{d F}{d t}=E=a \times b \times e^{-b(t-c)} \times e^{-e^{-b \mid t-c)}}
$$

A partir da determinação da Curva E, procederam-se os cálculos dos parâmetros dos modelos de Pequena Dispersão (PD), Grande Dispersão - Tanque Aberto (GD-TA), Grande Dispersão - Tanque Fechado (GD-TF) e CSTR’s em série (N-CSTR). As equações utilizadas são mostradas na Tabela 4.6.

Para permitir a comparação entre os modelos de PD, GD-TA e N-CSTR foi calculada a Soma dos Erros ao Quadrado (SEQ) entre os dados experimentais e os preditos pelos modelos a partir dos parâmetros determinados anteriormente. O modelo de GD-TF não foi avaliado por não possuir solução analítica.

\section{Danckwerts (1953)}

Para ensaios do tipo degrau, Danckwerts (1953) propôs a avaliação do número de dispersão (D/u.L) a partir da equação 4.5:

$$
\left(\frac{C}{C_{\theta}}\right)_{\text {degrau }}=F=\frac{1}{2} \times\left(1-\operatorname{erf}\left(\frac{1}{2} \times \sqrt{\frac{u \cdot L}{D}} \times \frac{\left(1-\frac{\theta}{T D H_{e}}\right)}{\sqrt{\frac{\theta}{T D H_{e}}}}\right)\right]
$$

O ajuste das Equações 4.3 e 4.5 aos dados experimentais foi realizado utilizando o software Microsoft Excel ${ }^{\circledR}$ por meio do algoritmo de otimização não linear de gradiente reduzido genérico (GRG2), minimizando a soma de erros ao quadrado (SEQ) entre os valores experimentais e os valores preditos pelo modelo. 
Tabela 4.6 - Parâmetros e equações adaptados dos modelos propostos por Levenspiel (1999).

\begin{tabular}{lc}
\hline \multicolumn{1}{c}{ Parâmetro } & Equação \\
\hline Tempo de detenção hidráulica experimental & $T D H_{e}=\frac{\int_{0}^{\infty} t \cdot E(t) \cdot d t}{\int_{0}^{\infty} E(t) \cdot d t}$ \\
Variância & $\sigma^{2}=\int_{0}^{\infty}\left(t-T D H_{e}\right)^{2} \cdot E(t) \cdot d t$ \\
Variância adimensional & $\sigma_{\theta}^{2}=\frac{\sigma^{2}}{T D H_{e}^{2}}$ \\
E adimensional & $E_{\theta}=T D H_{e} \cdot E$ \\
Tempo adimensional & $\theta=\frac{t}{T D H_{e}}$
\end{tabular}

Pequena dispersão (PD)

Número de dispersão

$$
\left(\frac{D}{u . L}\right)=\frac{\sigma_{\theta}^{2}}{2}
$$

E adimensional

$$
E_{\theta}=\frac{1}{2 \cdot \sqrt{\pi \cdot(D / u \cdot L)}} \exp \left[-\frac{(1-\theta)^{2}}{4(D / u \cdot L)}\right]
$$

Grande dispersão - Tanque Fechado (GD-TF)

Número de dispersão (D/u.L)

$$
\sigma_{\theta, t f}^{2}=2\left(\frac{D}{u \cdot L}\right)-2\left(\frac{D}{u \cdot L}\right)^{2}\left[1-e^{-u \cdot L / D}\right]
$$

Grande dispersão - Tanque Aberto (GD-TA)

Número de dispersão

$$
\sigma_{\theta, t a}^{2}=2\left(\frac{D}{u \cdot L}\right)+8\left(\frac{D}{u \cdot L}\right)^{2}
$$

E adimensional

$$
E_{\theta, t a}=\frac{1}{2 \cdot \sqrt{\pi \cdot(D / u \cdot L)}} \exp \left[-\frac{(1-\theta)^{2}}{4 \cdot \theta \cdot(D / u \cdot L)}\right]
$$

Tanques em série (N-CSTR)

Número de reatores

$$
N=\frac{1}{\sigma_{\theta}^{2}}=\frac{T D H_{e}^{2}}{\sigma^{2}}
$$

E adimensional

$$
E_{\theta}=\frac{N(N . \theta)^{N-1}}{(N-1) !} e^{-N \cdot \theta}
$$

\subsubsection{Adsorção do aldicarbe no meio suporte}

A avaliação da adsorção do aldicarbe no meio suporte foi realizada por meio da determinação da curva de exaustão empregando-se reatores diferenciais (Figura 4.4, adaptado 
de Ribeiro, 2001). Três reatores foram confeccionados em vidro de boro-silicato, com diâmetro interno de 2,9 cm, preenchidos com cubos de espumas de poliuretano, com $5 \mathrm{~mm}$ de aresta. O volume total do reator foi de $16,5 \mathrm{~mL}$. Para permitir a reprodução das condições encontradas no RAHLF, utilizou-se uma velocidade de escoamento de 4,2 cm.h ${ }^{-1}$, calculada em função dos parâmetros adotados para o RAHLF (TDH $=24$ horas, $\mathrm{V}_{\text {escoamento }}=0,8 \mathrm{~L}$ e porosidade de leito de $40 \%$ ). Foi, também, mantida a relação de massa de meio suporte por volume de reator (30 gramas em 2 L de volume total). Assim, foram adicionados 248,5 $\pm 0,8$ mg de espuma (média dos três reatores).

A solução de aldicarbe utilizada foi composta do produto comercial (após extração) e água destilada, de forma a se obter uma concentração teórica de aproximadamente $40 \mathrm{mg} . \mathrm{L}^{-1}$. Os ensaios foram realizados no tempo de 10 horas, com amostragens dos efluentes dos reatores de 30 em 30 minutos. As amostras do afluente (tanque agitado) foram retiradas de 2 em 2 horas. A temperatura foi de $30 \pm 1^{\circ} \mathrm{C}$. A concentração de aldicarbe foi determinada conforme método cromatográfico desenvolvido. Na Figura 4.5 é mostrada a representação esquemática do experimento.

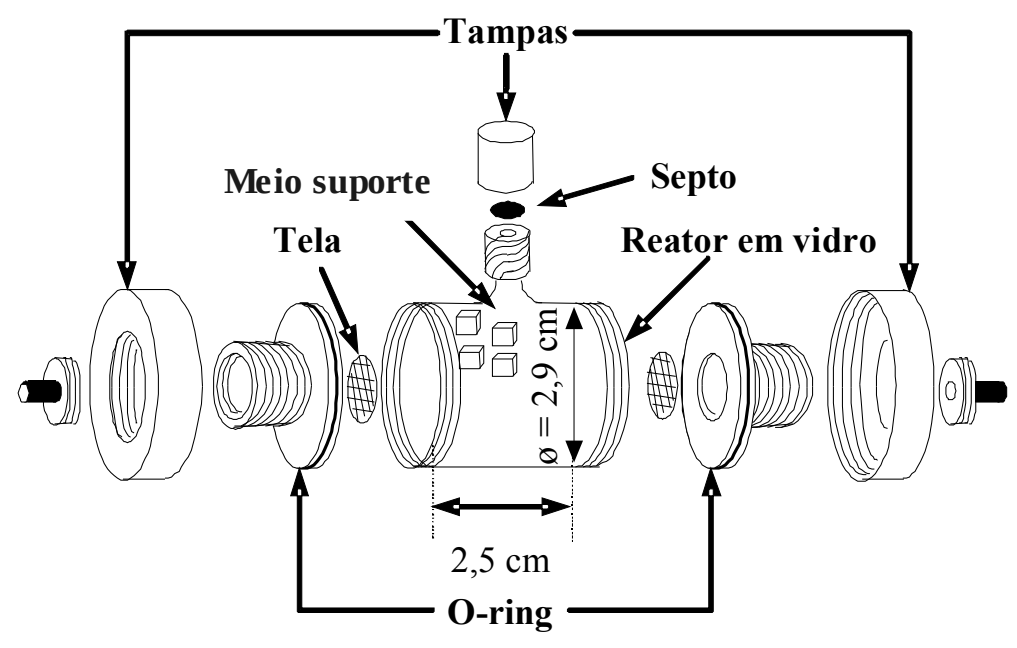

Figura 4.4. Representação esquemática do reator diferencial. 


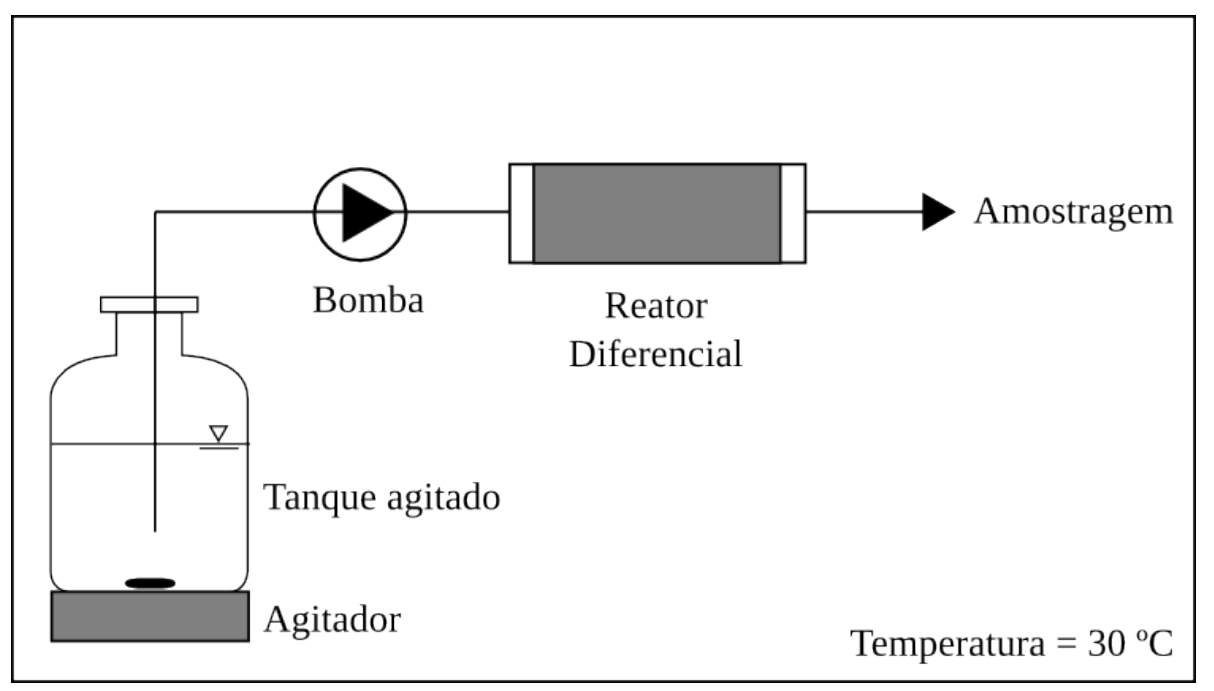

Figura 4.5. Representação esquemática do ensaio para determinação da curva de exaustão de aldicarbe no meio suporte.

A massa de aldicarbe adsorvida (MAA) foi determinada a partir da Equação 4.6.

$\mathrm{MAA}=\sum_{i=1}^{n} Q \cdot\left(C_{\text {afluente }}-C_{\text {efluente }}\right)_{i} \cdot\left(t_{i}-t_{i-1}\right)$

Em que:

MAA: $\quad$ massa de aldicarbe adsorvida (mgaldicarbe).

$n: \quad$ número total de amostragens.

i: $\quad$ amostragem.

Q: $\quad$ vazão $\left(L \cdot h^{-1}\right)$.

Cafluente: $\quad$ concentração afluente de aldicarbe (mg.L $\left.{ }^{-1}\right)$.

$\mathrm{C}_{\text {efluente: }} \quad$ concentração efluente de aldicarbe (mg. $\left.\mathrm{L}^{-1}\right)$.

$\mathrm{t}_{\mathrm{i}}$ : $\quad$ tempo de ensaio correspondente à amostragem $i(\mathrm{~h})$.

$\mathrm{t}_{\mathrm{i}-1}: \quad$ tempo de ensaio correspondente à amostragem anterior (h).

A massa de aldicarbe adsorvida no meio suporte (MAS) foi determinada a partir da Equação 4.7.

MAS $=$ MAA/MSS

Em que:

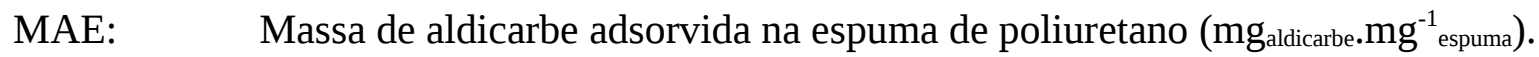

MSS: $\quad$ Massa de suporte seco (mgespuma). 


\subsection{Avaliação da degradação do aldicarbe na presença de diferentes aceptores de elétrons no RAHLF}

\subsubsection{Material}

\subsubsection{ReAtor ANAERóbio horizontal DE LEITO Fixo (RAHLF)}

Os reatores possuíram as características descritas no Item 4.2.1.1. A representação esquemática do sistema pode ser vista na Figura 4.2. O aparato experimental utilizado é exibido na Figura 4.6.

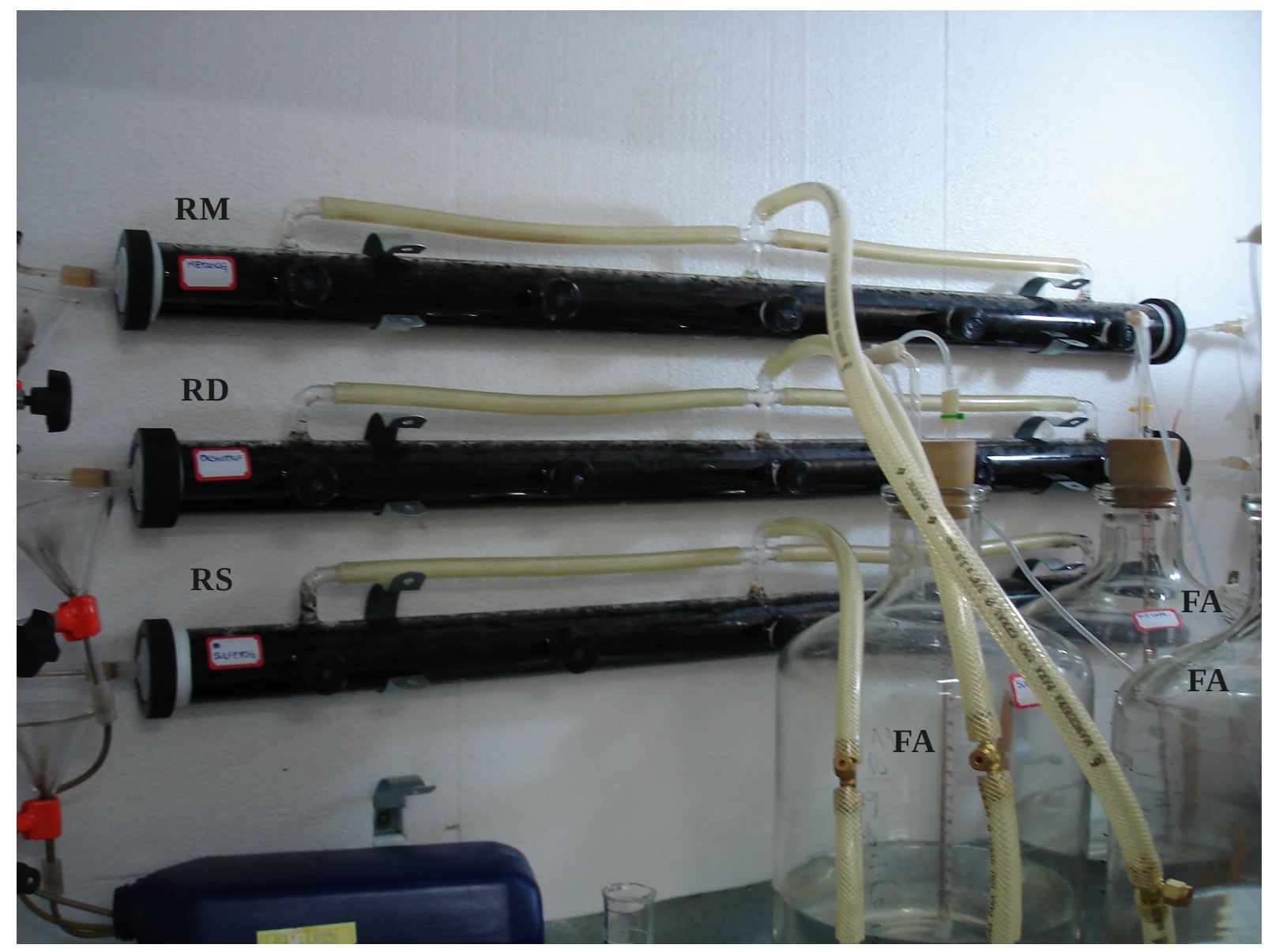

Figura 4.6. Aparato experimental.

[Notação: (RM) reator metanogênico, $(\mathrm{RD})$ reator desnitrificante,

(RS) reator sulfetogênico, (FA) frascos de alimentação]. 


\subsubsection{MEIO SUPORTE PARA IMOBILIZAÇão DA BIOMASSA}

O meio suporte possuiu as características descritas no Item 4.2.1.2.

\subsubsection{INÓCULO}

A biomassa granular utilizada no experimento foi proveniente de reator anaeróbio de manta de lodo e escoamento ascendente (UASB), tratando água residuária de abatedouro de aves da empresa Avícola Dacar sediada em Tietê, SP.

\subsubsection{MeIo SINTÉTICo}

O meio sintético usado foi composto de aldicarbe (extraído do produto comercial Temik $^{\circledR}$ ), meio basal (ANGELIDAKI; PETERSEN; AHRING, 1990) para suprimento de sais e metais, vitaminas (WOLIN; WOLIN; WOLFE, 1963) e bicarbonato de sódio. Na Tabela é descrito o meio que foi utilizado no estudo. Em função da condição de oxidação desejada, adicionou-se, também, nitrato ou sulfato.

Para estimular condições desnitrificantes em um dos reatores, foi adicionado nitrato ao meio (na forma de nitrato de sódio). A concentração adicionada foi determinada por meio da Equação 4.8, utilizando-se a relação estequiométrica $\mathrm{C} / \mathrm{N}$ considerando o metanol fonte de carbono e nitrato como fonte de nitrogênio, incluindo a síntese celular (ASCE/WEF, 1992):

$\mathrm{NO}_{3}{ }^{-}+1,08 \mathrm{CH}_{3} \mathrm{OH}+0,24 \mathrm{H}_{2} \mathrm{CO}_{3} \rightarrow 0,056 \mathrm{C}_{5} \mathrm{H}_{7} \mathrm{O}_{2} \mathrm{~N}+0,47 \mathrm{~N}_{2}+1,68 \mathrm{H}_{2} \mathrm{O}+\mathrm{HCO}_{3}{ }^{-}$

Assim, para cada 1,08 mol de metanol, seria necessário 1 mol de nitrato. Em massa seriam 62 g de nitrato para 34,6 g de metanol. Convertendo em demanda química de oxigênio (DQO), seriam necessários 62 g de nitrato para cada 51,9 g de DQO.

A DQO do Temik ${ }^{\circledR}$, determinada experimentalmente, foi de $1,7 \mathrm{~g}$ de DQO para cada $1 \mathrm{~g}$ de aldicarbe. Assim, como exemplo, na condição de $10 \mathrm{mg} . \mathrm{L}^{-1}$ de aldicarbe, seriam necessários 20,3 mg de nitrato. Portanto, a relação nitrato/aldicarbe utilizada foi de aproximadamente 2,03.

No reator sulfetogênico, foi adicionado sulfato $\left(\mathrm{SO}_{4}{ }^{2-}\right)$ (na forma de sulfato de sódio) ao meio considerando-se a relação teórica $\mathrm{DQO} /\left(\mathrm{SO}_{4}{ }^{2-}\right)$ de 0,67 , garantindo que haja sulfato 
suficiente para que toda a matéria orgânica seja consumida via sulfetogênese (LENS et al., 1988). Assim, para cada $1 \mathrm{~g}$ de aldicarbe, foram adicionados aproximadamente 2,5 g de sulfato.

\subsubsection{Métodos analíticos}

\subsubsection{Aldicarbe E metabólitos}

As amostras provenientes dos três reatores foram analisadas de acordo com o método desenvolvido empregando cromatógrafo líquido de alta eficiência (HPLC) (DAMASCENO et al., 2008).

\subsubsection{COMPOSIÇÃO DO BIOGÁs}

A determinação da composição do biogás foi feita através de cromatografia em fase gasosa utilizando-se o cromatógrafo $\mathrm{Gow}-\mathrm{Mac}^{\circledR}$ série 150 equipado com detector de condutividade térmica e coluna Porapak $\mathrm{Q}^{\circledR}(2 \times 1 / 4$ ” - 80 a 100 mesh). O gás de arraste foi hidrogênio a $1 \mathrm{~mL} . \mathrm{s}^{-1}$, a temperatura do injetor foi $55^{\circ} \mathrm{C}$, a corrente foi de $150 \mathrm{~mA}$ e o volume de amostra foi de $500 \mu \mathrm{L}$. A temperatura do forno e do detector foram de $55^{\circ} \mathrm{C}$. Esse equipamento não permitiu a detecção de baixas concentrações de sulfeto. Assim, no cálculo do percentual da composição do biogás, considerou-se o mesmo formado apenas por metano e gás carbônico.

\subsubsection{AlcAlinidade}

Inicialmente propôs-se monitorar a alcalinidade a bicarbonato ( $A B)$ nos três reatores segundo metodologia proposta por Dilallo e Albertson (1961) modificado por Ripley, Boyle e Converse (1986). Entretanto, o risco de exposição ao aldicarbe foi considerado elevado em função da necessidade de fervura da amostra (para determinação dos ácidos voláteis totais). Assim, o monitoramento da alcalinidade do processo foi realizada por meio da razão entre a alcalinidade intermediária e alcalinidade parcial (AI/AP). 


\subsubsection{Sulfato, SUlFEto, NitRito E NitRato}

As análises de sulfato/sulfeto e nitrato/nitrito foram realizadas no reator sulfetogênico e desnitrificante, respectivamente. Esses parâmetros foram avaliados de acordo com APHA (1999). Para a análise de sulfato foi necessária a construção da curva de calibração empregando-se o meio basal como solvente, visto que este influenciava na determinação analítica.

\subsubsection{Procedimento experimental}

\subsubsection{IMOBILIZAÇÃo DA BIOMASSA}

Para cada reator foram utilizados aproximadamente $500 \mathrm{~mL}$ de biomassa na forma de grânulos após drenagem do líquido intersticial presente na mesma (pelo emprego de peneira comum). A imobilização da biomassa na espuma de poliuretano foi adaptada do procedimento descrito por Zaiat, Cabral e Foresti (1994):

(a) A biomassa foi macerada pelo emprego de um liquidificador comum, de forma a destruir a estrutura granular e facilitar a sua fixação no meio suporte.

(b) O meio suporte foi adicionado ao inóculo e misturado de forma a permitir a fixação da biomassa.

(c) Após 2 horas, o meio suporte com a biomassa imobilizada foi acondicionado no reator, tomando-se o cuidado para que não houvesse compressão do mesmo.

Após a inoculação dos reatores com as biopartículas (meio suporte com biomassa imobilizada), a porosidade de leito foi de $40 \%$. Na análise de sólidos voláteis na biopartícula, utilizou-se o procedimento descrito por Damasceno (2004).

\subsubsection{EXTRAÇÃo DE ALDicARBE}

A solução estoque foi preparada a partir da extração do aldicarbe presente no produto comercial (Temik ${ }^{\circledR}$ ). A partir de sua composição (15\% de aldicarbe), o produto comercial foi disposto em água destilada (13,5 gramas para $900 \mathrm{~mL}$ de água) sendo submetido à agitação magnética por 30 minutos. Após filtração em membrana de microfibra de vidro de 1,2 $\mu$ m de abertura, adicionou-se água destilada para completar o volume de $1000 \mathrm{~mL}$ de solução, de forma a se obter a concentração teórica final de aproximadamente 2,0 g. $\mathrm{L}^{-1}$ de aldicarbe. 
Entretanto, esse protocolo permitiu a extração média de 1,4 g.L $\mathrm{L}^{-1}$, ou seja, $70 \%$ da concentração teórica.

\subsubsection{EstABILIDADE DO ALDICARBE NO FRASCO DE ALIMENTAÇão}

Para se avaliar a variação do aldicarbe no frasco de alimentação, três frascos contendo aldicarbe na concentração de 6 mg. $\mathrm{L}^{-1}$ e o meio sintético foram submetidos à temperatura de $30 \pm 1^{\circ} \mathrm{C}$, sem esterilização, durante aproximadamente 30 dias. As amostras coletadas durante o ensaio foram analisadas de acordo com o método desenvolvido empregando cromatógrafo líquido de alta eficiência (HPLC) (DAMASCENO et al., 2008).

\subsubsection{AvaliaçÃo DO EFEITO DO AUMENTO DA CONCENTRAÇÃO NA DEGRADAÇÃo DO ALDICARBE NA PRESENÇA DE DIFERENTES ACEPTORES DE ELÉTRONS}

Os três reatores foram operados simultaneamente nas mesmas condições de operação (concentração, tempo de detenção hidráulica e temperatura), diferindo apenas seu nível de oxidação (metanogênico, desnitrificante e sulfetogênico). O tempo de detenção hidráulica (TDH) utilizado foi de 24 horas.

Os reatores foram operados inicialmente na concentração de $10 \mathrm{mg} \cdot \mathrm{L}^{-1}$. Entretanto, em função do desempenho dos mesmos, foi necessária a adequação das concentrações inicialmente propostas. Assim, as concentrações afluentes de aldicarbe testadas foram:

- Ensaio 5: 5 mg. $\mathrm{L}^{-1}$.

- Ensaio 10: $10 \mathrm{mg} \cdot \mathrm{L}^{-1}$.

- Ensaio 20: 20 mg. $\mathrm{L}^{-1}$.

- Ensaio 30: $30 \mathrm{mg} \cdot \mathrm{L}^{-1}$.

- Ensaio 40: $40 \mathrm{mg} \cdot \mathrm{L}^{-1}$.

A ordem de execução dos ensaios foi: 10, 30, 5, 20 e 40. O Ensaio 40 não foi realizado no reator desnitrificante, uma vez que o seu desempenho foi inadequado nas concentrações de 20 e 30 mg.L ${ }^{-1}$.

A análise da remoção de aldicarbe levou em consideração a soma total dos metabólitos medidos (sulfóxido e sulfona de aldicarbe) com o composto principal como sendo aldicarbe total. Esse tipo de consideração é comum em estudos com aldicarbe já que as três substâncias apresentam toxicidade semelhante, devendo, portanto, ser removidas no processo de biorremediação. 
Em cada uma das concentrações avaliadas, após atingir o equilíbrio dinâmico aparente, foram realizados perfis temporais (em cada reator ao longo do seu comprimento). Os parâmetros analisados foram concentração de aldicarbe e metabólitos, sulfato/sulfeto e nitrato/nitrito.

Ao final de cada ensaio, após a determinação dos perfis temporais ao longo dos reatores, foi realizada a mudança da concentração afluente por meio da troca do frasco de alimentação. Após três dias de operação no ensaio é que iniciava-se o monitoramento da eficiência de conversão de aldicarbe. Para a determinação dos valores médios, os valores iniciais da concentração de aldicarbe no efluente foram desconsiderados no cálculo.

Os parâmetros cinéticos aparentes de degradação no RAHLF foram determinados a partir dos respectivos perfis temporais ajustando-se a Equação 4.9 para o reator metanogênico e sulfetogênico, ou a Equação 4.10 para o reator desnitrificante, em função de seus dados experimentais. Em todos sistemas, o regime de escoamento foi considerado como sendo tubular ideal, de acordo com os ensaios hidrodinâmicos realizados anteriormente. O ajuste foi realizado no software Microcal Origin ${ }^{\circledR} 6.0$ por meio do algoritmo de Levenberg-Marquardt.

$$
S_{b}=S_{\min }+\left(S_{0}-S_{\min }\right) \cdot e^{-k_{\text {lap }} \cdot t}
$$

Em que:

$\mathrm{S}_{\mathrm{b}}$ : $\quad$ concentração de substrato no meio líquido $\left(\mathrm{mg}_{\text {aldicarbe. }} \mathrm{L}^{-1}\right)$.

$\mathrm{S}_{0}$ : $\quad$ concentração de substrato no meio líquido no tempo igual a zero (mgaldicarbe. $\mathrm{L}^{-1}$ ).

$\mathrm{S}_{\min }$ : concentração mínima de substrato no meio líquido (mgaldicarbe. $\left.\mathrm{L}^{-1}\right)$.

$\mathrm{k}_{1 \text { ap }}$ : constante cinética aparente de primeira ordem $\left(\mathrm{h}^{-1}\right)$.

t: $\quad$ tempo de detenção hidráulica ao longo do RAHLF (h).

$$
S_{b}=-k_{0 \text { ap }} \cdot t
$$

Em que:

$\mathrm{k}_{0 \mathrm{ap}}: \quad$ constante cinética aparente de ordem zero $\left(\mathrm{mgaldicarbe.}^{-1} \cdot \mathrm{h}^{-1}\right)$. 


\subsection{Cinética da degradação biológica do aldicarbe sob condições metanogênicas}

\subsubsection{Avaliação da transferência de massa externa e interna}

Para a avaliação dos efeitos da transferência de massa externa e interna na degradação do aldicarbe sob condições metanogênicas adaptou-se o protocolo proposto por Vieira (1996) e Zaiat (1996) utilizando-se reatores diferenciais.

\subsubsection{Material}

Os ensaios foram realizados em reatores diferenciais (Figura 4.4) conectados, em circuito fechado, a frascos de $50 \mathrm{~mL}$ submetidos à agitação, a $30 \pm 1^{\circ} \mathrm{C}$. No protocolo original o tanque agitado era refrigerado a $4{ }^{\circ} \mathrm{C}$. Entretanto, como o aldicarbe apresentou estabilidade em $30^{\circ} \mathrm{C}$ em ambiente não estéril, optou-se por manter também o tanque agitado submetido às condições do ensaio. A representação esquemática do sistema pode ser vista na Figura 4.7. O aparato experimental utilizado é exibido na Figura 4.8.

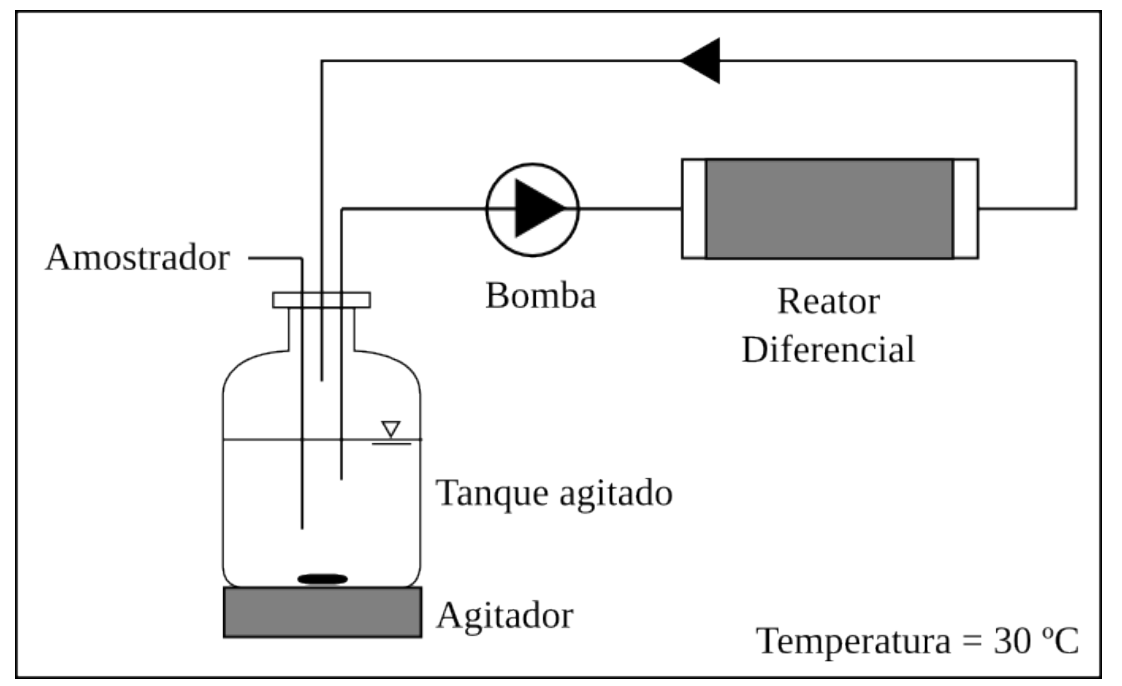

Figura 4.7. Representação esquemática do aparato experimental para determinação de parâmetros cinéticos intrínsecos de degradação do aldicarbe sob condições metanogênicas.

O inóculo, o meio suporte e o procedimento de imobilização da biomassa foram os mesmos utilizados nos ensaios com o RAHLF. Após a imobilização as biopartículas ficaram 
em contato com o efluente do reator anaeróbio por 60 dias a fim de que fosse promovida a sua adaptação.

O substrato sintético foi composto de aldicarbe (concentração de $10 \mathrm{mg} . \mathrm{L}^{-1}$ ) e meio sintético de acordo com o que foi descrito anteriormente (Tabela 4.2).

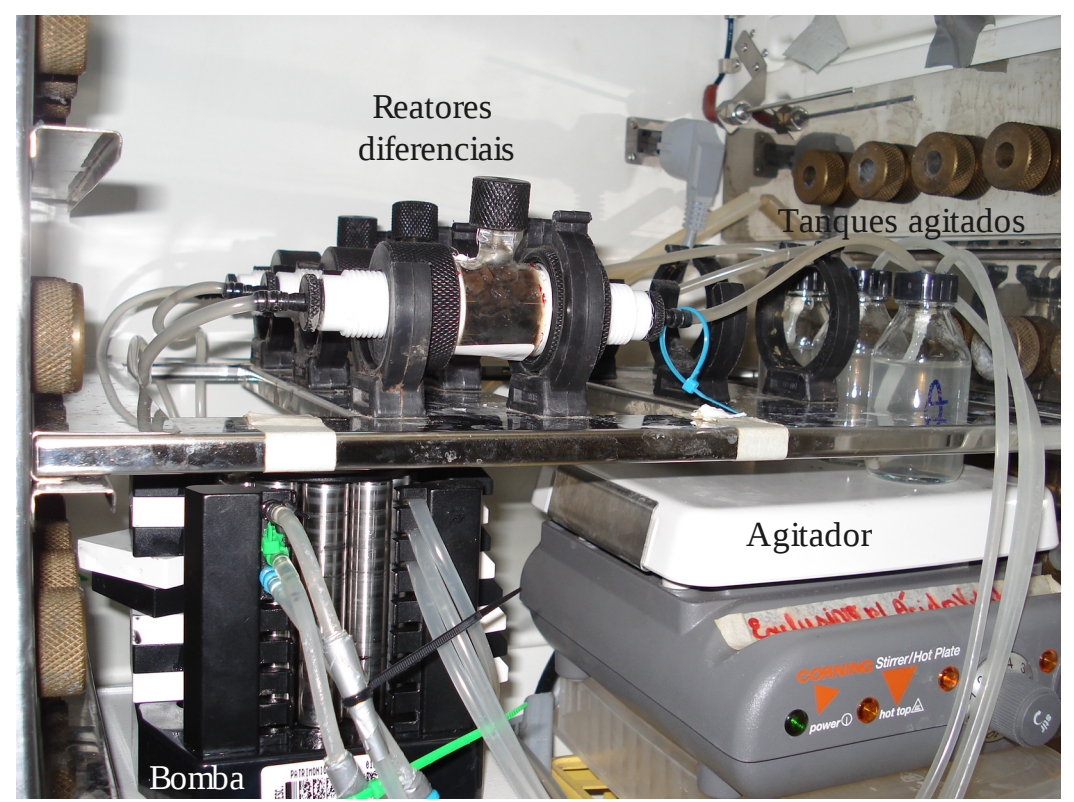

Figura 4.8. Aparato experimental para determinação de parâmetros cinéticos intrínsecos de degradação do aldicarbe sob condições metanogênicas.

\subsubsection{Procedimento EXPERIMENTAL}

Os reatores diferenciais foram inoculados com as biopartículas adaptadas e operados durante 10 dias em regime contínuo para sua adaptação à concentração de $10 \mathrm{mg}$. $\mathrm{L}^{-1}$. A velocidade de escoamento superficial nesse período foi de $4,2 \mathrm{~cm} \cdot \mathrm{h}^{-1}$, semelhante à utilizada no RAHLF operando no TDH de 24 horas. Após esse período, foi dado início aos ensaios experimentais, em regime de batelada.

Para avaliar a condição de minimização da resistência externa à transferência de massa foram realizados 4 ensaios em diferentes velocidades de escoamento, sendo essas definidas a partir das velocidades de escoamento teóricas no RAHLF em escala de bancada em diferentes tempos de detenção hidráulica (Tabela 4.7). 
Tabela 4.7 - Velocidades de escoamento superficial avaliadas e tempos de detenção hidráulica equivalentes no RAHLF em escala de bancada.

\begin{tabular}{cc}
\hline $\mathrm{v}_{\mathrm{s}}\left(\mathrm{cm} \cdot \mathrm{h}^{-1}\right)$ & $\mathrm{TDH}(\mathrm{h})$ \\
\hline 4,2 & 24,0 \\
25,5 & 4,0 \\
78,3 & 1,3 \\
203,7 & 0,5 \\
\hline
\end{tabular}

Cada ensaio foi realizado em duplicata, com duração de 48 horas e retirada de amostras de $500 \mu \mathrm{L}$ a cada 12 horas. Um reator adicional foi submetido às mesmas condições dos demais a fim de se estimar, ao final dos ensaios, a concentração de biomassa (X) na espuma de poliuretano conforme metodologia desenvolvida por Zaiat (1996). A determinação do aldicarbe $\left(S_{b}\right)$ foi feita de acordo com o método cromatográfico desenvolvido (DAMASCENO et al., 2008).

\subsubsection{TRATAMENTO DOS DADOS EXPERIMENTAIS}

A avaliação da resistência à transferência de massa externa e interna foi feita a partir dos perfis de concentração do substrato $\left(\mathrm{S}_{\mathrm{b}}\right)$ ao longo do tempo $(\mathrm{t})$ utilizando-se o método das velocidades iniciais.

Ajustou-se a Equação 4.11 aos dados experimentais.

$$
S_{b}=y_{0}+A \cdot \mathrm{e}^{\frac{-t}{T}}
$$

Em que:

$\mathrm{S}_{\mathrm{b}}$ : $\quad$ concentração de substrato em meio líquido (mg. $\left.\quad \mathrm{L}^{-1}\right)$.

yo, A, T: parâmetros de ajuste da equação.

$\mathrm{t}: \quad$ tempo $(\mathrm{h})$.

As velocidades observadas de consumo de substrato $\left(R_{o b s}\right)$ ao longo do tempo $\left(t_{i}\right)$, foram determinadas como sendo: 


$$
\left|R_{o b s}\right|_{t=t_{i}}=-\left|\frac{d S b}{d t}\right|_{t=t_{i}}=\frac{A \cdot \mathrm{e}^{-t / T}}{T}
$$

Em que:

$\mathrm{R}_{\mathrm{obs}}$ : velocidade observada de consumo de substrato (mgaldicarbe $\cdot \mathrm{L}^{-1} \cdot \mathrm{h}^{-1}$ ).

As velocidades específicas observadas de utilização de substrato $\left(\mathrm{r}_{\mathrm{obs}}\right)$ ao longo do tempo (t), foram determinadas como sendo:

$$
r_{o b s}=\frac{R_{o b s}}{X}
$$

\section{Em que:}

$\mathrm{r}_{\mathrm{obs}}$ : $\quad$ velocidade específica observada de consumo de substrato (mgaldicarbe.mgSVT ${ }^{-1} \cdot \mathrm{h}^{-1}$ ).

X: $\quad$ concentração de biomassa no reator $\left(\mathrm{mgSVT} . \mathrm{L}^{-1}\right)$.

Para avaliar a condição de minimização da resistência externa à transferência de massa, foi obtida a velocidade específica inicial de utilização de substrato observada $\left|r_{o b s}\right|_{t=0}$ para cada $\mathrm{V}_{\mathrm{s}}$. O perfil de $\left|r_{o b s}\right|_{t=0}$ ao longo de $\mathrm{v}_{\mathrm{s}}$ permite verificar a minimização da camada de líquido estagnado ao redor das biopartículas, condição em que $\mathrm{r}_{\mathrm{obs}}$ deve assumir um valor constante.

A magnitude dos efeitos da resistência à transferência de massa intraparticular foi avaliada, para os sistemas que operaram na ausência de limitação externa à difusão, através do módulo de Thiele observado ( $\phi_{\mathrm{obs}}$ ). De acordo com Bringi e Dale (1990), se $\phi_{\mathrm{obs}}<0,3$, a resistência interna à transferência de massa pode ser desprezada. Os valores de $\phi_{\text {obs }}$ foram obtidos a partir da Equação 4.14, utilizando-se $\mathrm{r}_{\text {obs }}$ para t igual a zero em sua determinação.

$$
\phi_{o b s}=\frac{r_{o b s} X R_{e q}^{2}}{9 D_{e} S_{b}}
$$

\section{Em que:}

$\phi_{\text {obs: }}$ módulo de Thiele observado (adimensional).

$\mathrm{R}_{\mathrm{eq}}$ : raio da esfera equivalente $(\mathrm{cm})$.

$\mathrm{D}_{\mathrm{e}}$ : difusividade efetiva do substrato na biopartícula $\left(\mathrm{cm}^{2} \cdot \mathrm{s}^{-1}\right)$. 
A difusividade efetiva do substrato na biopartícula foi considerada como sendo a difusividade do aldicarbe em solução aquosa (De $=8 \cdot 10^{-6} \mathrm{~cm}^{2} \cdot \mathrm{s}^{-1}$ ), apresentada por Perry e Green (1997). Como a concentração de aldicarbe foi baixa e a espuma de poliuretano proporciona um ambiente de elevada macroporosidade, a difusidade na matriz imobilizada pode ser considerada como sendo semelhante à em solução aquosa (FAZOLO, 2003).

\subsubsection{Determinação dos parâmetros cinéticos intrínsecos de degradação}

Após a avaliação dos efeitos da resistência à transferência de massa, para estimar os parâmetros cinéticos intrínsecos de degradação do aldicarbe em condições metanogênicas, os parâmetros cinéticos foram determinados a partir das concentrações de substrato no meio líquido e suas respectivas velocidades específicas observadas de consumo de substrato (Equação 4.13) para os ensaios nos quais foram satisfeitas ambas as condições de minimização da resistência externa e interna à transferência de massa.

Em função dos resultados experimentais, partiu-se do modelo cinético de Monod (MONOD, 1942) adaptado por Giraldo-Gomes, Goodwin e Switzenbaum (1992) que considera a existência de uma concentração mínima $\left(S_{\min }\right)$ (Equação 4.15$)$ para que ocorra consumo de substrato:

$$
r_{o b s}=r_{\max } \times \frac{\left(S_{b}-S_{\min }\right)}{K s+\left(S_{b}-S_{\min }\right)}
$$

Em que:

robs: velocidade específica observada de consumo de substrato (mgaldicarbe.mgSVT ${ }^{-1} \cdot \mathrm{h}^{-1}$ ).

$\mathrm{r}_{\max }$ : velocidade específica máxima de consumo de substrato (mgaldicarbe.mgSVT-1 $\mathrm{mb}^{-1}$ ).

$\mathrm{S}_{\mathrm{b}}$ : $\quad$ concentração de substrato no meio líquido $\left(\mathrm{mg}_{\text {aldicarbe. }} \mathrm{L}^{-1}\right)$.

$\mathrm{S}_{\min }$ : concentração mínima de substrato no meio líquido (mgaldicarbe. $\mathrm{L}^{-1}$ ).

Ks: $\quad$ constante de saturação (mgaldicarbe. $\left.L^{-1}\right)$.

Ademais, partindo do princípio que em baixas concentrações o modelo de Monod apresenta-se como sendo de $1^{\text {a }}$ ordem, a Equação 4.16 foi utilizada para determinar os parâmetros cinéticos intrínsecos de degradação do aldicarbe sob condições metanogênicas. 


$$
r_{o b s}=k_{1} \cdot\left(S_{b}-S_{\text {min }}\right)
$$

Em que:

$\mathrm{k}_{1}$ : $\quad$ constante cinética de primeira ordem $\left(\mathrm{L} \cdot \mathrm{mgSVT}^{-1} \cdot \mathrm{h}^{-1}\right)$.

\subsubsection{Validação dos parâmetros cinéticos intrínsecos}

O procedimento de validação foi proposto a partir da simulação dos perfis temporais da concentração de aldicarbe ao longo do reator sob condições metanogênicas. Para isso, os parâmetros cinéticos determinados no RAHLF e nos reatores diferenciais foram utilizados para simulação dos perfis por meio da Equação 4.17, considerando o sistema como tubular ideal, em função dos ensaios hidrodinâmicos realizados anteriormente.

$$
S_{b}=S_{\min }+\left(S_{0}-S_{\min }\right) \cdot e^{-k_{1} \cdot X \cdot t}
$$

Assim, para cada uma das concentrações de aldicarbe afluentes, simulou-se a variação da concentração ao longo do RAHLF. A validação do procedimento foi realizada por meio de avaliação estatística do modelo utilizado na simulação empregando-se o Teste F modificado, conforme proposto por Bonomi e Schmidell (2001), o qual baseia-se na obtenção do "erro experimental”.

Na medida em que não se dispõe de uma medida precisa da estimativa do erro experimental, uma vez que não foram fornecidas repetições de um mesmo ensaio, a partir das quais esta estimativa seria obtida, a aplicação do Teste F deve ser modificada, calculando-se o erro experimental que, se existente, garante que o modelo simulado represente adequadamente os dados experimentais (BONOMI; SCHMIDELL, 2001). Assim, para o experimento, a estimativa do erro experimental foi determinada a partir da Equação 4.18.

$$
\varepsilon>\sqrt{\frac{s_{c}^{2} \cdot\left((n v)_{e}-v\right)}{\sum_{i=1}^{n}\left(C_{\text {aldicarbe }}\right)^{2}}}
$$

Em que:

$s_{c}^{2}: \quad$ estimativa da variância do erro do modelo. 
$(n v)_{e}: \quad$ número de pontos experimentais (35).

$v: \quad$ número de variáveis (1).

Caldicarbe: $\quad$ concentração de aldicarbe no perfil temporal.

A estimativa da variância do erro do modelo $\left(s_{c}^{2}\right)$ foi determinada pela Equação 4.19.

$$
s_{c}^{2}=\frac{\sum_{i=1}^{v} \sum_{j=1}^{n}\left(\tilde{y}_{i j}-y_{i j}\right)^{2}}{(n v)_{c}-p}
$$

Em que:

$\tilde{y}_{i j}: \quad$ valor da variável calculado pelo modelo.

$y_{i j}: \quad$ valor experimental da variável.

$(n v)_{c}: \quad$ número de pontos ajustados (35).

p: $\quad$ número de parâmetros do modelo (3).

\subsection{Exames microbiológicos}

\subsubsection{Microscopia ótica}

Os exames microbiológicos do lodo anaeróbio foram realizados por microscopia ótica empregando-se microscópio Olympus ${ }^{\circledR}$ modelo BX 60-FLA acoplado a câmera colorida digital Optronics ${ }^{\circledR}$. O software utilizado para aquisição de imagens foi o Image Pro-Plus ${ }^{\circledR}$ 3.0.1. As amostras foram avaliadas ao término da última etapa de operação. Todas foram examinadas em lâminas de vidro cobertas com filme de ágar a 2 \%.

As amostras foram retiradas da primeira, terceira e quinta portas de amostragem e analisadas em conjunto.

\subsubsection{Análise da diversidade microbiana}

A determinação da diversidade microbiana presente nos reatores foi realizada usando a técnica de reação em cadeia da polimerase e eletroforese em gel de gradiente desnaturante (PCR/DGGE) (Figura 4.9). Foram analisadas as seguintes amostras: (a) inóculo; (b) biopartículas ao término da etapa de $10 \mathrm{mg}^{-\mathrm{L}^{-1}}$ para os três reatores; (c) biopartículas ao 
término da etapa de $30 \mathrm{mg} . \mathrm{L}^{-1}$ para o reator desnitrificante e $40 \mathrm{mg} . \mathrm{L}^{-1}$ para os reatores metanogênico e sulfetogênico.

$\mathrm{Na}$ coleta das biopartículas retirou-se aproximadamente 5 cubos de cada porta de amostragem, dispondo-as em mesmo recipiente. O DNA foi extraído de acordo com o protocolo de Griffths et al. (2000).

\subsubsection{AMPLIFICAÇão POR PCR}

$\mathrm{Na}$ amplificação dos fragmentos do gene RNAr 16S foram utilizados primers específicos (Tabela 4.8) para os domínios Archaea (KUDO et al., 1997) e Bacteria (NIELSEN et al., 1999) com GC clamp (MUYZER; WALL; UITTERLINDEN, 1993). Os fragmentos de DNA amplificados foram separados por (DGGE).

Tabela 4.8 - Primers utilizados para PCR.

\begin{tabular}{lll}
\hline Domínio & \multicolumn{1}{c}{ Primers e seqüência (5' - 3') } & \multicolumn{1}{c}{ Referência } \\
\hline \multirow{5}{*}{ Archaea } & 1100 FGC (5' - AAC CGT CGA CAG TCA GGY & \\
& AAC GAG CGAG - 3'). & Kudo et al. (1997) \\
& GCG GGG GCA CGG GGGG - 3') & \\
& 968 FGC (5' - AAC CGC GAA GAA CCT TAC - 3') & \\
Bacteria & 1392 R (5' - AACG GGC GGT GTG TAC - 3') & Nielsen et al. (1999) \\
& GC clamp (5'- CGC CCG CCG GGG CGC CCG & \\
\hline
\end{tabular}

Tabela 4.9 - Programação do termociclador para amplificação dos fragmentos do RNAr 16S.

\begin{tabular}{ccc}
\hline \multirow{2}{*}{ Parâmetros } & \multicolumn{2}{c}{ Domínio } \\
\cline { 2 - 3 } & Archaea & Bacteria \\
\hline Ciclos & 35 & 35 \\
Desnaturação inicial & $94^{\circ} \mathrm{C}$ & $94^{\circ} \mathrm{C}$ \\
Desnaturação & $1,30 \mathrm{~min}$ & $5 \mathrm{~min}$ \\
& $94^{\circ} \mathrm{C}$ & $94{ }^{\circ} \mathrm{C}$ \\
Anelamento & $0,30 \mathrm{~min}$ & $1,30 \mathrm{~min}$ \\
& $55^{\circ} \mathrm{C}$ & $38{ }^{\circ} \mathrm{C}$ \\
Extensão & $0,30 \mathrm{~min}$ & $45 \mathrm{~s}$ \\
& $72{ }^{\circ} \mathrm{C}$ & $72{ }^{\circ} \mathrm{C}$ \\
Extensão final & $1,30 \mathrm{~min}$ & $1 \mathrm{~min}$ \\
& $94^{\circ} \mathrm{C}$ & $72{ }^{\circ} \mathrm{C}$ \\
Resfriamento & $3,0 \mathrm{~min}$ & $5 \mathrm{~min}$ \\
& $4{ }^{\circ} \mathrm{C}$ & $4{ }^{\circ} \mathrm{C}$ \\
\hline
\end{tabular}


Na reação de amplificação do fragmento do RNAr 16S dos microrganismos dos Domínio Bacteria e, Archaea foram usadas as soluções: 0,5 $\mu \mathrm{L}$ de Taq DNA polymerase (5 U. $\mu \mathrm{L}^{-1}$ ); $5 \mu \mathrm{L}$ de tampão PCR 10X; 1,5 $\mu \mathrm{L}$ de $\operatorname{MgCl}_{2}$ (50 mM); $5 \mu \mathrm{L}$ de dNTP (2 mM); $1 \mu$ $\mathrm{L}$ de primer forward $(100 \mathrm{pmol})$ e $1 \mu \mathrm{L}$ do primer reverse $(100 \mathrm{pmol})$ e $2 \mu \mathrm{L}$ de DNA extraído. O aparelho utilizado nessa técnica foi o termociclador GeneAmp ${ }^{\circledR}$ PCR System 2400 (Perkin-Elmer/Cetus, Norwalk, Conn).

As condições usadas na programação do aparelho para amplificação do fragmento de RNAr 16S estão descritas na Tabela 4.9.

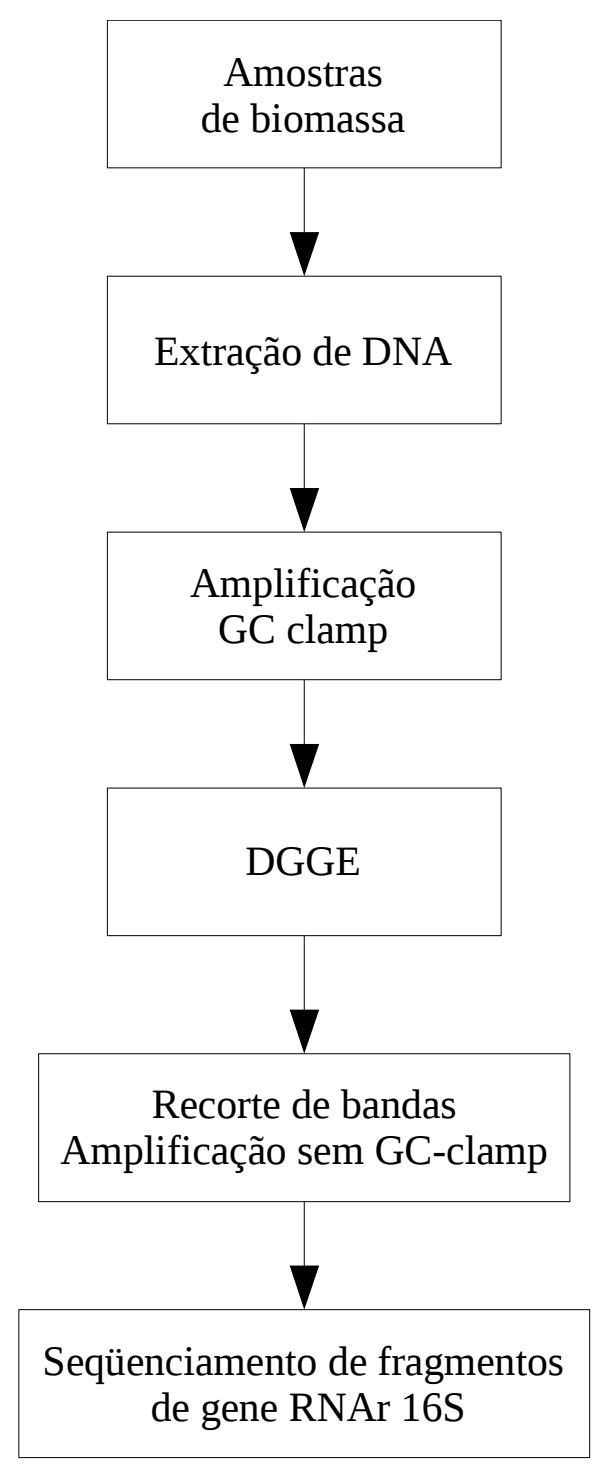

Figura 4.9. Fluxograma da análise da estrutura da comunidade microbiana usando PCR/DGGE. 


\subsubsection{DGGE}

O DGGE é uma técnica que permite a separação dos fragmentos de RNA de mesmo tamanho, porém com seqüências de nucleotídeos diferentes. A separação desses fragmentos ocorre de acordo com o grau de desnaturação da dupla hélice de DNA, sob a ação do gel de poliacrilamida, com gradiente crescente dos agentes desnaturantes (formamida e uréia).

Para o Domínio Bacteria foram usadas concentrações de 30\% e 60\% do gel de gradiente desnaturante (gel acrilamida - 40\%; solução 50X de TAE -Tris Ácido Acético EDTA; formamida e uréia), enquanto para o Domínio Archaea os valores foram de $40 \%$ e 60\%. Os géis foram preparados com $111 \mu \mathrm{L}$ de APS (perssulfato de amônia-10\%); $11 \mu \mathrm{L}$ de TEMED (tetrametiletilenodiamina). Após a solidificação do gel (1 hora), as placas contendo o gel foram colocadas em suporte apropriado e levadas à cuba de DGGE. Nesta cuba foram adicionados $7 \mathrm{~L}$ de água destilada e $140 \mathrm{~mL}$ de TAE 50X. A temperatura de “corrida” do gel foi constante $\left(65^{\circ} \mathrm{C}\right)$, voltagem de $175 \mathrm{~V}$, com duração de 16 horas. O gel foi retirado da cuba e corado com brometo de etídio por 20 minutos e depois transferido para o fotodocumentador Eagle Eye TM III ${ }^{\circledR}$ (Stratagene) acoplado ao computador e software Eagle Slight UV ${ }^{\circledR}$ para visualização das bandas, sob exposição à UV de 254 nm.

\subsubsection{AnÁlises de SeqüEnciamento}

As seqüências de nucleotídeos de fragmento do gene RNAr 16S recuperado de bandas de gel de DGGE foram amplificadas por PCR usando os mesmos sets de primers para cada Domínio, porém sem o GC clamp, e purificados por kit de purificação de PCR (Mobio). Foram seqüenciados aproximadamente 300 pb em seqüenciador automático de capilar ABI PRISM 310 (Applied Biosystem ${ }^{\circledR}$ ) usando kit Big Dye Terminator de acordo com as recomendações do fabricante. As seqüências obtidas foram verificadas no programa DNAStar.

As aproximações filogenéticas para microrganismos conhecidos foram determinadas pelo Basic Local Alignment Search Tool (BLAST) do National Center for Biotechnology Information (NCBI) (http://www.ncbi.nlm.nih.gov/blast).

As árvores filogenéticas foram construídas por análise de bootstrap usando método de Neighbor-joing através do programa Mega v.4 (TAMURA et al., 2007). 


\section{RESULTADOS E DISCUSSÃO}

\subsection{Desenvolvimento de método de deteç̧ão de aldicarbe, sulfóxido de aldicarbe e sulfona de aldicarbe por cromatografia líquida de alta eficiência (HPLC)}

Os dados apresentados neste item encontram-se publicados em Damasceno et al. (2008).

\subsubsection{Determinação de aldicarbe, sulfóxido de aldicarbe e sulfona de aldicarbe}

As condições cromatográficas selecionadas foram ideais para a identificação dos picos individuais, resultando em separação adequada dos analitos, como pode ser visto na Figura 5.1. Foi necessário o emprego de um tempo de atraso de 2,3 minutos na leitura do detector para evitar a interferência das substâncias que estavam presentes no meio sintético. Apesar do pico de aldicarbe ter ocorrido no tempo de 13,16 min (Tabela 5.4), fluxionou-se a coluna para evitar a interferência entre amostras, retornando às condições iniciais do gradiente da fase móvel. Embora tenham sido realizados testes para reduzir o tempo de análise, não obteve-se êxito, seja pela variação dos tempos de retenção ou pelo aparecimento de picos “fantasmas”.

\subsubsection{Validação do método}

As curvas de calibração foram lineares na faixa investigada, tanto com água quanto com meio sintético como solvente. A Tabela 5.1 resume os dados da regressão das curvas de calibração, coeficientes de correlação $\left(\mathrm{r}^{2}\right)$ e coeficientes máximos de correlação $\left(\mathrm{r}^{2}\right.$ max $)$ de cada analito. A Tabela 5.2 apresenta os resultados dos testes de linearidade para uma significância estatística de 95\%. 


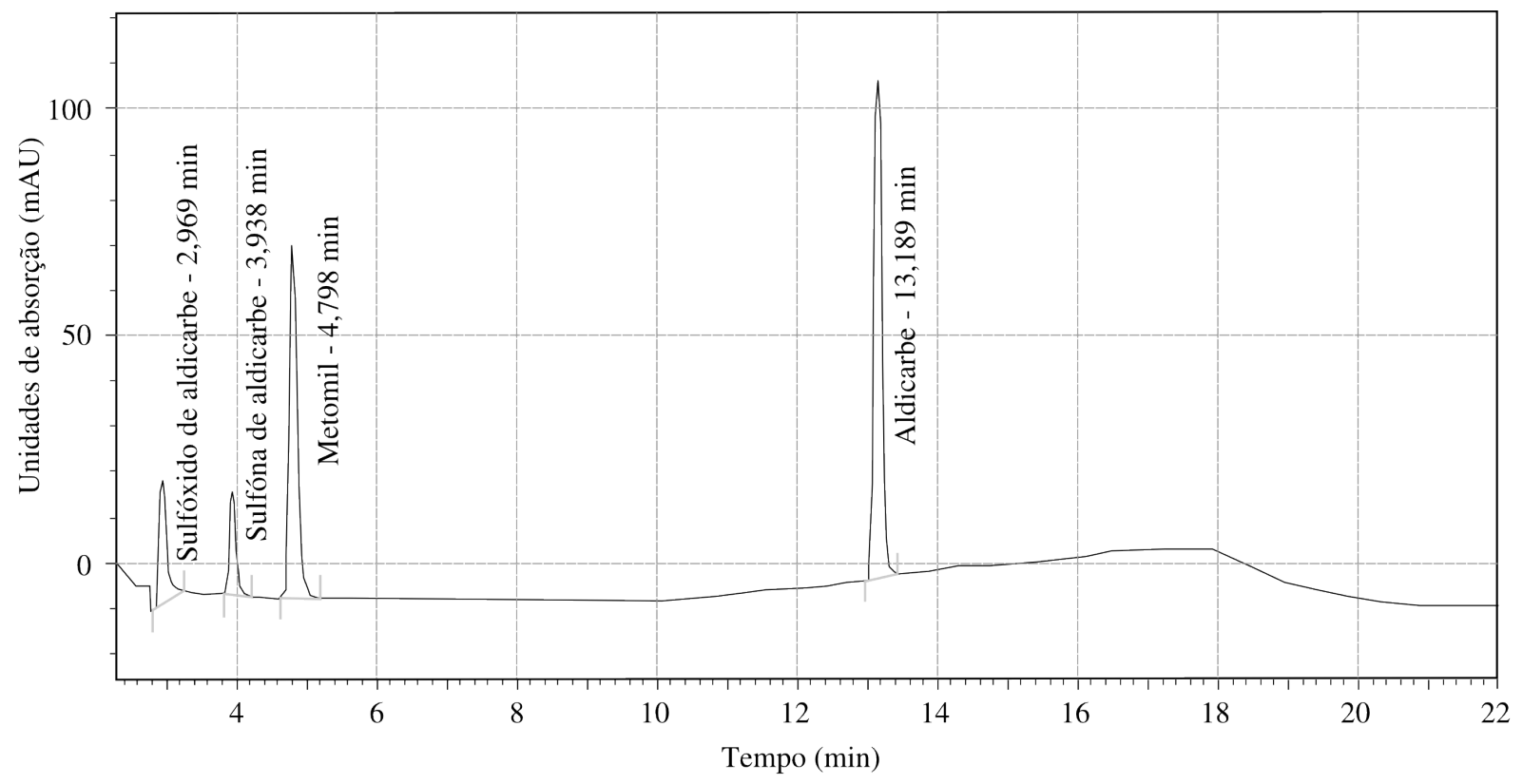

Figura 5.1. Cromatograma típico obtido em meio sintético.

Tabela 5.1 - Curvas de regressão e testes de eficiência de regressão.

\begin{tabular}{ccccc}
\hline Analito & Solução & Equação & $\mathrm{r}^{2}$ & $\mathrm{r}_{\text {max }}^{2}$ \\
\hline \multirow{2}{*}{ Aldicarbe } & Água & $\mathrm{y}=0,2385 \times \mathrm{x}+0,0274$ & 0,9985 & 0,9989 \\
& Meio sintético & $\mathrm{y}=0,2380 \cdot \mathrm{x}+0,0262$ & 0,9989 & 0,9995 \\
\hline Sulfóxido de & Água & $\mathrm{y}=0,2458 \cdot \mathrm{x}-0,0125$ & 0,9996 & 0,9997 \\
Aldicarbe & Meio sintético & $\mathrm{y}=0,2590 \cdot \mathrm{x}+0,0611$ & 0,9974 & 0,9983 \\
\hline Sulfona de & Água & $\mathrm{y}=0,2599 \cdot \mathrm{x}-0,0044$ & 0,9987 & 0,9987 \\
Aldicarbe & Meio sintético & $\mathrm{y}=0,2510 \cdot \mathrm{x}+0,0026$ & 0,9997 & 0,9998 \\
\hline
\end{tabular}

Tabela 5.2 - Resultados dos testes de linearidade com significância estatística de 95\%.

\begin{tabular}{|c|c|c|c|c|c|}
\hline \multirow{2}{*}{ Analito } & \multirow{2}{*}{ Solução } & \multicolumn{2}{|c|}{ ALM } & \multicolumn{2}{|c|}{ VR } \\
\hline & & $F_{5 ; 14 ; 0.025}$ & $F_{\text {obtido }}$ & $F_{1 ; 19 ; 0.025}$ & $F_{\text {obtido }}$ \\
\hline \multirow{2}{*}{ Aldicarbe } & Água & \multirow{6}{*}{ 3,66 } & 1,07 & \multirow{6}{*}{5,92} & 12298,07 \\
\hline & Meio sintético & & 2,90 & & 17938,19 \\
\hline \multirow{2}{*}{$\begin{array}{l}\text { Sulfóxido de } \\
\text { Aldicarbe }\end{array}$} & Água & & 1,12 & & 46388,27 \\
\hline & Meio sintético & & 1,46 & & 7142,34 \\
\hline \multirow{2}{*}{$\begin{array}{l}\text { Sulfona de } \\
\text { Aldicarbe }\end{array}$} & Água & & 0,06 & & 14921,74 \\
\hline & Meio sintético & & 1,45 & & 56144,86 \\
\hline
\end{tabular}

De acordo com metodologia desenvolvida (CHUI; ZUCHINI; LICHTIG, 2001, CHUI, 2007), no ajuste do modelo linear (ALM), se o valor de F obtido a partir da ANOVA ( $F_{\text {obtido }}$ ) 
for inferior ao $\mathrm{F}$ estatístico ( $\left.\mathrm{F}_{\text {crítico }}\right)\left(\mathrm{F}_{\text {obtido }}<\mathrm{F}_{\text {crítico }}\right)$, o ajuste do modelo é considerado satisfatório. O teste de validade da regressão (VR) demonstra que a inclinação da regressão linear (m) é diferente de zero. Assim, se o valor de F obtido a partir da ANOVA ( $\mathrm{F}_{\text {obtido }}$ ) for superior ao $\mathrm{F}$ estatístico ( $\left.\mathrm{F}_{\text {crítico }}\right)\left(\mathrm{F}_{\text {obtido }}>>\mathrm{F}_{\text {crítico }}\right.$ ), é uma indicação de que o valor de $\mathrm{m}$ é diferente de zero (nulo). Os coeficientes de relação linear foram superiores a 0,99 (Tabela 5.1), evidenciando ocorrência de linearidade (BRASIL, 2003). As curvas de regressão em água ultrapurificada e meio sintético foram estatisticamente significantes, uma vez que o teste estatístico não excedeu o valor crítico.

Os valores de $r^{2}$ e dos coeficientes máximos de regressão $\left(r^{2}{ }_{\max }\right)$ foram próximos. Isto indica que o erro devido à regressão é próximo do erro puro e que deve ser devido ao procedimento analítico, validando o uso do modelo linear.

Os valores de LOD e LOQ foram menores nas soluções de calibração em água do que aqueles obtidos quando o meio sintético é empregado como solvente (Tabela 5.3). A precisão do método e a precisão instrumental estimados pelo coeficiente de variação (CV) dos tempos de retenção são mostradas na Tabela 5.4. A precisão do método foi medida a partir das curvas de calibração em meio sintético, com CV menores que 3,32\%. A precisão instrumental, estimada a partir de 10 injeções da mesma solução padrão em meio sintético, variou de 0,8 a 1,58\%. Valores abaixo de 5\% demonstram a precisão do método (BRASIL, 2003).

Tabela 5.3 - Limite de detecção (LOD) e limite de quantificação (LOQ) dos analitos em água e meio sintético.

\begin{tabular}{cccc}
\hline Analito & Solução & LOD $\left(\mathrm{mg} \cdot \mathrm{L}^{-1}\right)$ & LOQ $\left(\mathrm{mg} . \mathrm{L}^{-1}\right)$ \\
\hline \multirow{2}{*}{ Aldicarbe } & Água & 0,391 & 1,303 \\
\cline { 2 - 4 } & Meio sintético & 0,440 & 1,466 \\
\hline Sulfóxido de & Água & 0,069 & 0,230 \\
\cline { 2 - 4 } aldicarbe & Meio sintético & 0,192 & 0,641 \\
\hline Sulfona de & Água & 0,033 & 0,109 \\
\cline { 2 - 4 } aldicarbe & Meio sintético & 0,068 & 0,228 \\
\hline
\end{tabular}


Tabela 5.4 - Precisão e precisão instrumental do método para cada analito em meio sintético.

\begin{tabular}{lcccc}
\hline Analito & $\mathrm{t}_{\text {ret }}(\min )^{\mathrm{a}, \mathrm{b}}$ & $\mathrm{CV}(\%)^{\mathrm{b}}$ & $\mathrm{t}_{\text {ret }}(\mathrm{min})^{\mathrm{a}, \mathrm{c}}$ & $\mathrm{CV}(\%)^{\mathrm{c}}$ \\
\hline Aldicarbe & $13,166 \pm 0.129$ & 0,982 & $13,270 \pm 0.106$ & 0,80 \\
Metomil & $4,873 \pm 0.098$ & 2,02 & $4,892 \pm 0.076$ & 1,56 \\
Sulfona de aldicarbe & $3,988 \pm 0.084$ & 2,10 & $4,001 \pm 0.059$ & 1,47 \\
Sulfóxido de aldicarbe & $2,949 \pm 0.098$ & 3,32 & $2,946 \pm 0.038$ & 1,29
\end{tabular}

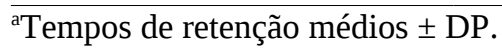

${ }^{\text {b}}$ Valores obtidos da curva de calibração $(n=3)$.

${ }^{c}$ Valores obtidos a partir de injeções repetidas da mesma solução padrão (n = 10).

\subsection{Ensaios preliminares}

\subsubsection{Hidrodinâmica do RAHLF em condições abióticas}

A utilização do cloreto de sódio como traçador foi adequada, principalmente devido à forte adsorção dos outros traçadores testados (Eosina Y e Rodamina Bt) e por sua semelhança à Dextrana Azul, que é um traçador aplicado com sucesso em outros estudos.

\subsubsection{Modelos PRopostos Por LeVenspiel (1999)}

O ajuste dos dados experimentais à sigmóide de Gompertz foi adequado, representado pelos coeficientes de correlação $\left(\mathrm{r}^{2}\right)$ elevados determinados em todas as condições avaliadas (superiores a 0,98). A partir dos coeficientes ajustados (a, b e c), foi possível determinar a Curva E pela derivada da função sigmóide. Um padrão típico observado em todos os ensaios é mostrado na Figura 5.2, para o tempo de detenção hidráulica teórico $\left(\mathrm{TDH}_{\mathrm{t}}\right)$ de 3 horas.

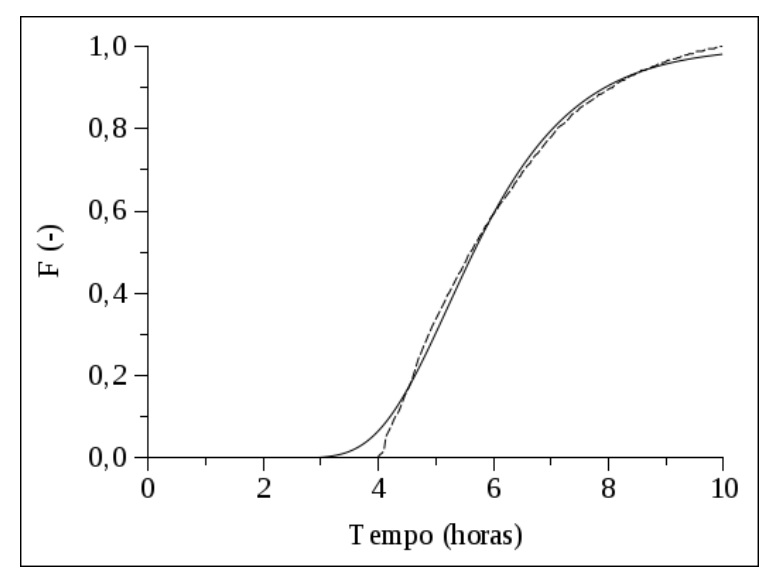

(a)

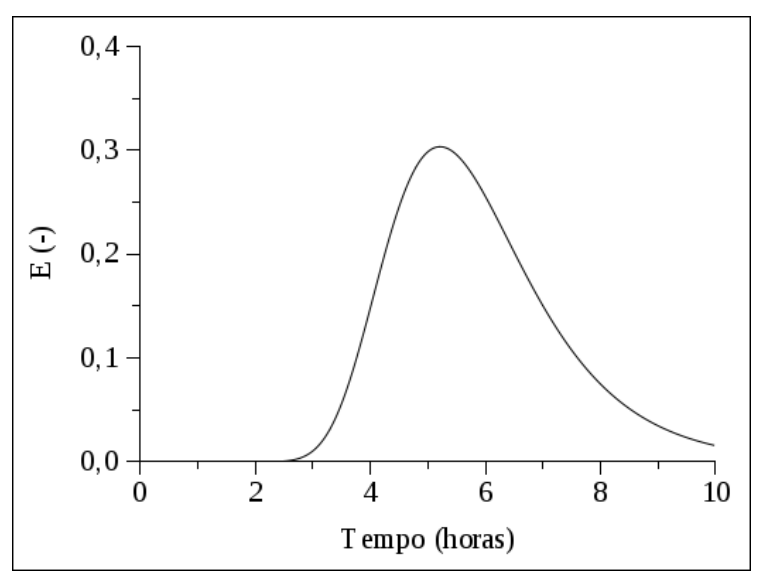

(b)

Figura 5.2. Padrão típico das Curvas F (a) e E (b).

[Notação: —-, dados experimentais; ---, sigmóide de Gompertz.] 
A Tabela 5.5 mostra os valores médios dos parâmetros para os modelos hidrodinâmicos propostos por Levenspiel (1999). Em todos os ensaios o modelo de tanquesem-série (N-CSTR) não foi adequado, como pode ser visto na Figura 5.3.a, para o tempo de detenção hidráulica teórico $\left(\mathrm{TDH}_{\mathrm{t}}\right)$ de 3 horas. Portanto, este modelo foi desprezado nas análises posteriores (Figura 5.3.b).

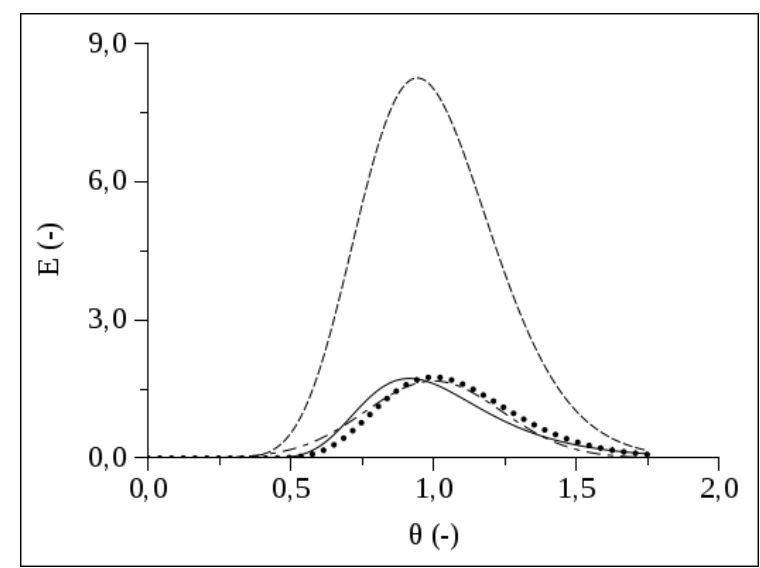

(a)

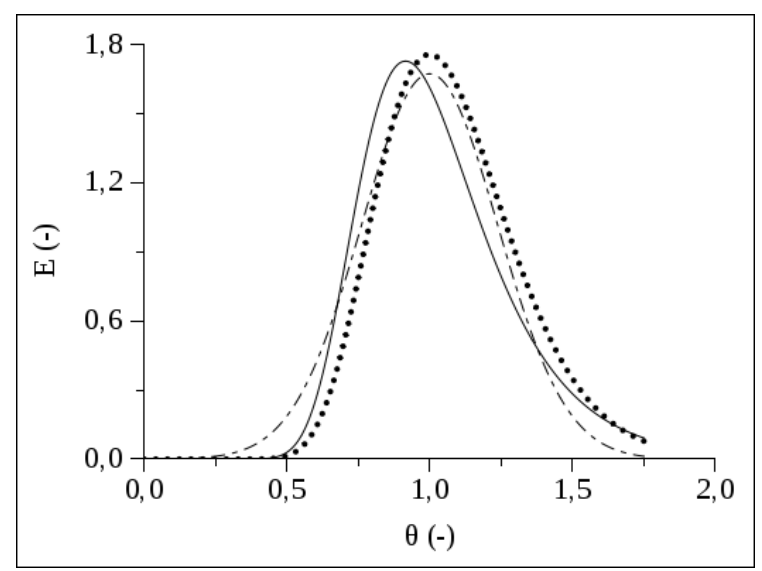

(b)

Figura 5.3. Padrão típico das curvas de E adimensional.

[Notação: ——, dados experimentais; ---, modelo de N-CSTR; — -, modelo de PD; •••, GD-TA.]

\subsubsection{MODELO PROPOSTO POR DANCKWERTS}

O ajuste dos dados experimentais ao modelo proposto por Danckwerts (1953) foi adequado em todos os ensaios. Na Figura 5.4 é mostrado um ajuste típico encontrado para este modelo (no exemplo, para o $\mathrm{TDH}_{\mathrm{t}}$ de 3 horas). A Tabela 5.6 mostra os valores médios dos parâmetros para o modelo proposto por Danckwerts (1953). 


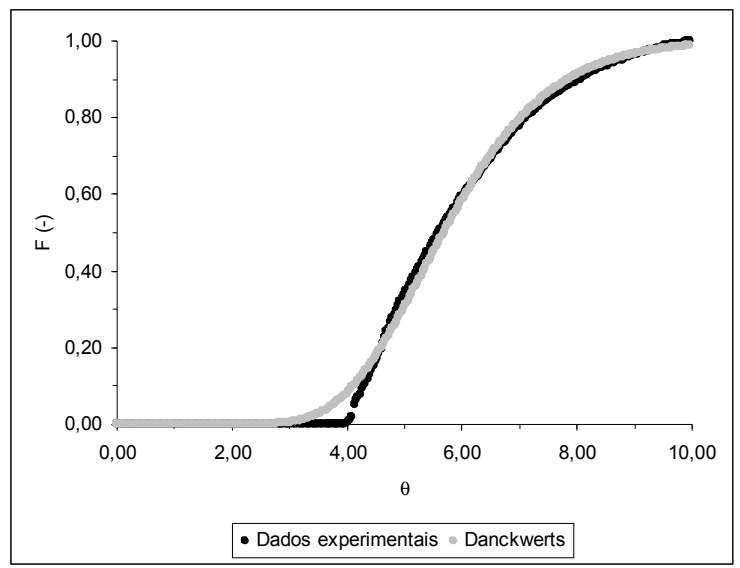

Figura 5.4. Ajuste típico do modelo de Danckwerts aos dados experimentais.

Para os modelos propostos por Levenspiel, a partir dos valores da SEQ, verificou-se que o modelo de Pequena Dispersão (PD) ajustou-se melhor em relação ao modelo de Grande Dispersão em Tanque Aberto (GD-TA).

Na Figura 5.5 são mostrados os valores médios do número de dispersão em função da variação dos tempos de detenção hidráulica testados, para os modelos propostos por Levenspiel (1999) e Danckwerts (1953). A linha contínua representa apenas a tendência dos dados experimentais.

É importante observar que a aplicação do modelo de Danckwerts é válida para pequenos números de dispersão (D/u.L < 0,1). Nestas condições, observou-se que os modelos de Pequena Dispersão e de Danckwerts são equivalentes em termos da determinação do número de dispersão e do volume de escoamento, validando o emprego de ambos como ferramenta de caracterização hidrodinâmica neste tipo de reator. Ademais, o ajuste dos dados experimentais à sigmóide foi válido, em que pese o ajuste do modelo de pequena dispersão aos dados experimentais da curva $E$ adimensional $\left(E_{\theta}\right)$ não ter sido satisfatório. Esta observação é importante se for considerado que o tratamento matemático é mais simples nos modelos propostos por Levenspiel, facilitando a aplicação desta técnica na caracterização de reatores. 
Tabela 5.5 - Valores médios dos parâmetros dos modelos propostos por Levenspiel (1999).

\begin{tabular}{|c|c|c|c|c|c|c|c|}
\hline \multirow{2}{*}{ Parâmetros } & \multicolumn{7}{|c|}{$\mathrm{TDH}_{\mathrm{t}}(\mathrm{h})$} \\
\hline & 3 & 6 & 8 & 12 & 16 & 18 & $24^{*}$ \\
\hline $\mathrm{TDH}_{\mathrm{e}}(\mathrm{h})$ & $5,6 \pm 0,1$ & $11,1 \pm 0,3$ & $11,5 \pm 0,5$ & $17,9 \pm 0,2$ & $23,0 \pm 1,1$ & $26,6 \pm 3,5$ & 41,9 \\
\hline $\mathrm{V}(\mathrm{L})$ & $1,49 \pm 0,04$ & $1,48 \pm 0,04$ & $1,15 \pm 0,03$ & $1,19 \pm 0,01$ & $1,15 \pm 0,05$ & $1,18 \pm 0,15$ & 1,4 \\
\hline$\sigma^{2}$ & $2,2 \pm 0,5$ & $5,3 \pm 0,2$ & $7,3 \pm 0,8$ & $7,0 \pm 0,5$ & $12,1 \pm 1,4$ & $27,0 \pm 2,2$ & 44,4 \\
\hline$\sigma$ & $1,48 \pm 0,18$ & $2,31 \pm 0,04$ & $2,70 \pm 0,14$ & $2,64 \pm 0,10$ & $3,47 \pm 0,21$ & $5,20 \pm 0,22$ & 6,66 \\
\hline$\sigma_{\theta}^{2}$ & $0,071 \pm 0,020$ & $0,043 \pm 0,001$ & $0,055 \pm 0,003$ & $0,022 \pm 0,002$ & $0,023 \pm 0,001$ & $0,040 \pm 0,013$ & 0,025 \\
\hline$s^{3}$ & $2,4 \pm 0,4$ & $10,5 \pm 1,1$ & $15,6 \pm 6,1$ & $23,8 \pm 0,5$ & $57,4 \pm 0,3$ & $174,9 \pm 41,0$ & 353,9 \\
\hline \multicolumn{8}{|l|}{$\underline{\mathrm{PD}}$} \\
\hline D/u.L & $0,036 \pm 0,010$ & $0,022 \pm 0,001$ & $0,027 \pm 0,001$ & $0,011 \pm 0,001$ & $0,011 \pm 0,000$ & $0,020 \pm 0,007$ & 0,013 \\
\hline SEQ & $4,5 \pm 1,3$ & $11,6 \pm 2,1$ & $9,7 \pm 0,2$ & $15,3 \pm 0,2$ & $12,4 \pm 3,9$ & $11,1 \pm 5,2$ & 15,3 \\
\hline \multicolumn{8}{|l|}{$\underline{\text { GD-TF }}$} \\
\hline D/u.L & $0,037 \pm 0,011$ & $0,022 \pm 0,001$ & $0,028 \pm 0,001$ & $0,011 \pm 0,001$ & $0,012 \pm 0,000$ & $0,020 \pm 0,007$ & 0,013 \\
\hline \multicolumn{8}{|l|}{$\underline{\text { GD-TA }}$} \\
\hline D/u.L & $0,032 \pm 0,008$ & $0,020 \pm 0,000$ & $0,025 \pm 0,001$ & $0,011 \pm 0,001$ & $0,011 \pm 0,000$ & $0,018 \pm 0,006$ & 0,012 \\
\hline SEQ & $9,8 \pm 0,04$ & $17,6 \pm 3,4$ & $14,6 \pm 0,7$ & $18,1 \pm 0,3$ & $13,3 \pm 6,9$ & $14,4 \pm 6,3$ & 18,3 \\
\hline
\end{tabular}

* Somente um ensaio foi realizado. 
Tabela 5.6 - Valores médios dos parâmetros do modelo de Danckwerts (1953).

\begin{tabular}{|c|c|c|c|c|}
\hline \multirow{2}{*}{ Parâmetros } & \multicolumn{4}{|c|}{$\mathrm{TDH}_{\mathrm{t}}(\mathrm{h})$} \\
\hline & 3 & 6 & 8 & 12 \\
\hline $\mathrm{TDH}_{\mathrm{e}}(\mathrm{h})$ & $5,6 \pm 0,2$ & $10,9 \pm 0,4$ & $11,3 \pm 0,3$ & $17,7 \pm 0,2$ \\
\hline $\mathrm{V}(\mathrm{L})$ & $1,49 \pm 0,04$ & $1,45 \pm 0,06$ & $1,13 \pm 0,03$ & $1,18 \pm 0,01$ \\
\hline D/u.L & $0,041 \pm 0,013$ & $0,021 \pm 0,000$ & $0,026 \pm 0,001$ & $0,010 \pm 0,001$ \\
\hline \multirow[t]{3}{*}{ SEQ } & $0,101 \pm 0,030$ & $0,083 \pm 0,059$ & $0,132 \pm 0,049$ & $0,103 \pm 0,004$ \\
\hline & \multicolumn{4}{|c|}{$\mathrm{TDH}_{\mathrm{t}}(\mathrm{h})$} \\
\hline & 16 & \multicolumn{2}{|c|}{18} & $24^{*}$ \\
\hline $\mathrm{TDH}_{\mathrm{e}}(\mathrm{h})$ & $23,0 \pm 0,6$ & \multicolumn{2}{|c|}{$26,3 \pm 3,2$} & 41,6 \\
\hline$V(L)$ & $1,15 \pm 0,03$ & \multicolumn{2}{|c|}{$1,17 \pm 0,14$} & 1,39 \\
\hline D/u.L & $0,011 \pm 0,000$ & \multicolumn{2}{|c|}{$0,019 \pm 0,008$} & 0,012 \\
\hline SEQ & $0,159 \pm 0,083$ & \multicolumn{2}{|c|}{$0,154 \pm 0,084$} & 0,201 \\
\hline
\end{tabular}

* Somente um ensaio foi realizado.

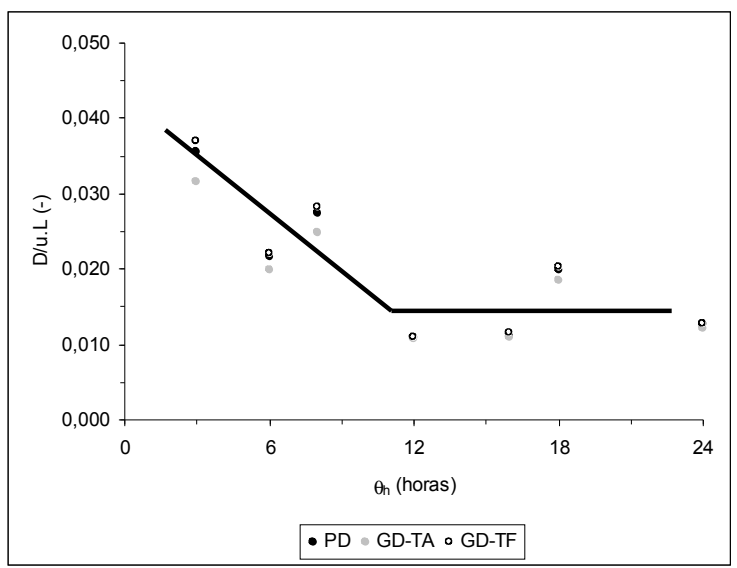

(a)

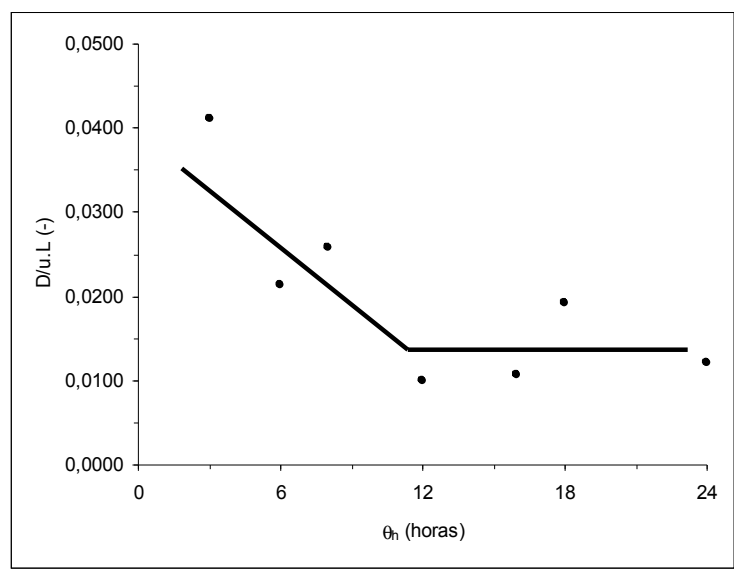

(b)

Figura 5.5. Variação do número de dispersão (D/u.L) em função do $\mathrm{TDH}_{\mathrm{t}}$ para os modelos propostos por Levenspiel (1999) (a) e Danckwerts (1953) (b).

O número de dispersão reduziu à medida que se aumentou o tempo de detenção hidráulica de 3 a 12 horas, permanecendo aproximadamente constante até 24 horas. Essa variação também também foi observada por De Nardi et al. (1999), que avaliaram a hidrodinâmica de um RAHLF preenchido com argila expandida utilizando-se a dextrana azul como traçador para tempos de detenção hidráulica de 2,4, 5,4 e 7,4 horas. Apesar da análise de variância (ANOVA) ter indicado que não houve diferença significativa entre os valores do número de reatores em série $(\mathrm{N})$ com a variação do tempo de detenção hidráulica, houve 
tendência de aumento da dispersão com o aumento da velocidade de escoamento. Kramers e Alberda (1953), utilizando cloreto de sódio como traçador em reator preenchido com anéis de Rasching, também determinaram que o aumento da velocidade de escoamento ocasionou um incremento no grau de mistura no sistema.

O aumento do número de dispersão (D/u.L) com o aumento da velocidade de escoamento pode ser efeito do aumento proporcionalmente maior da difusão (D) em relação à velocidade de escoamento (u) para um mesmo comprimento (L).

Os tempos de detenção hidráulica determinados pelos ensaios não coincidiram com os adotados teoricamente, indicando que o volume líquido inicialmente adotado não foi adequado. Durante todos ensaios foram determinados os volumes de água contidos no reator por meio de drenagem do líquido e compressão do meio suporte. O valor médio experimental do volume foi de $1,34 \pm 0,05 \mathrm{~L}$, enquanto que o valor médio determinado pelos modelos (PD e

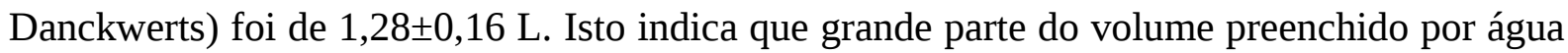
(95\%) foi utilizado como volume de escoamento. Considerando que os ensaios foram realizados em condições abióticas, estes resultados devem ser utilizados com cautela, visto que em condições bióticas parte do volume ocupado pela água é preenchido pela biomassa imobilizada, reduzindo o volume de escoamento no sistema. No entanto, estes resultados podem ser utilizados como um indicativo do escoamento predominante no RAHLF.

\subsubsection{Avaliação da adsorção do aldicarbe em espuma de poliuretano}

Em sistemas de biorremediação, muitas vezes é difícil separar fenômenos físicoquímicos de fenômenos biológicos, impossibilitando identificar qual variável foi responsável pela remoção de determinado poluente. Entre os biorreatores que utilizam meio suporte este fenômeno é mais evidente devido à sua ação adsorvente. A adsorção de compostos específicos tem sido observada em sistemas de tratamento de resíduos que utilizaram espuma de poliuretano (DE NARDI , 2002, RIBEIRO, 2005, BRUCHA et al., 2005, DUARTE, 2006, MIQUELETO, 2006). Assim, a quantificação da capacidade adsorvente da espuma de poliuretano torna-se essencial para uma melhor avaliação deste tipo de sistema.

Na Figura 5.6 são mostradas as curvas de exaustão obtidas nos reatores diferenciais. 


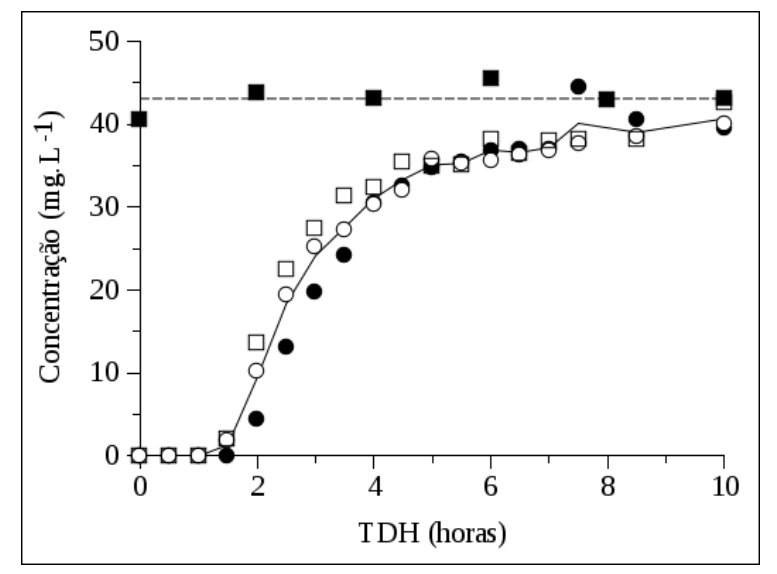

Figura 5.6. Concentração de aldicarbe no ensaio de exaustão.

[Notação: •, Reator A; ○, Reator B; $\square$, Reator C; ——, Média; •, Afluente; ---, Média Afluente.]

Como pode ser observado, no volume tratado de $120 \mathrm{~mL}$ (correspondente ao tempo de ensaio de 10 horas), ocorreu a exaustão do suporte, ou seja, a capacidade máxima de adsorção da espuma de poliuretano foi atingida neste ponto. Assim, nesse tempo, a massa média de aldicarbe adsorvida na espuma de poliuretano (MAS) foi de 7,3 $\pm 0,4$ mgaldicarbe. $^{-1}$ espuma.

De Nardi (2002) avaliou a adsorção de benzeno, etilbenzeno, tolueno e o-xileno na espuma de poliuretano em condições abióticas e bióticas. Foram realizados ensaios em batelada nestas condições. A capacidade máxima de adsorção para condições abióticas foi de 3,2, 4,5 e 4,3 mg.gespuma ${ }^{-1}$, para o tolueno, etilbenzeno e o-xileno, respectivamente (para o benzeno não foi possível a determinação). Em condições bióticas, a capacidade máxima de adsorção foi de 1,0, 1,6, 2,1 e 1,9 mg.gespuma ${ }^{-1}$, para o benzeno, tolueno, etilbenzeno e o-xileno, respectivamente.

Duarte (2006) avaliou a adsorção do alquilbenzeno linear sulfonado (LAS) em espuma de poliuretano, por meio da curva de exaustão, obtendo a o valor de 20,8 mg.gespuma ${ }^{-1}$. Miqueleto (2007) avaliou a adsorção de óleo de soja na espuma de poliuretano empregando-se as isotermas de Langmuir e Freundlich construídas a partir de dados experimentais obtidos em ensaios com o reator anaeróbio operado em bateladas seqüenciais com biomassa imobilizada (ASBBR). A capacidade máxima de adsorção, em condições abióticas, foi de 588 mg.g espuma $^{-1}$.

De forma geral, observa-se que, quanto mais hidrofóbico o composto for, maior é a adsorção à espuma de poliuretano. Como a superfície da espuma de poliuretano é hidrofóbica (SILVA et al., 2006), o aldicarbe, sendo hidrofílico, apresenta pouca tendência à adsorção nesse tipo de material. Supondo-se que a capacidade máxima de adsorção de aldicarbe seja mantida no RAHLF, a seriam adsorvidos 219 mg de aldicarbe. Para uma concentração afluente de $10 \mathrm{mg} . \mathrm{L}^{-1}$, seriam necessários 21,9 litros de meio para saturar toda a espuma. 
Assim, seriam necessários aproximadamente 28 dias para saturação de todo o reator (TDH = 24 horas). Contudo, este fenômeno raramente é observado de forma isolada, já que fenômenos biológicos coexistirão com o fenômeno da adsorção.

\subsection{Degradação do aldicarbe na presença de diferentes aceptores de elétrons}

Neste item encontram-se os resultados obtidos no que diz respeito à degradação do aldicarbe em diferentes condições anaeróbias (metanogênese, sulfetogênese e desnitricação). Inicialmente são mostrados os dados do período de partida dos reatores. Na seqüência, a apresentação é feita separadamente, para cada condição analisada. Dentro da mesma condição, são descritos os resultados obtidos para diferentes concentrações afluentes de aldicarbe. Ao final é feita a discussão a respeito dos resultados obtidos.

\subsubsection{Partida dos reatores}

Antes do início da operação dos reatores, realizou-se o teste de estabilidade do aldicarbe no frasco de alimentação com a finalidade de se avaliar se o mesmo seria degradado por hidrólise ou outro mecanismo. Mesmo sem a esterilização do frasco, após 30 dias e 9 amostragens em triplicata no período, a concentração de aldicarbe média foi de 6,2 $\pm 0,1 \mathrm{mg} . \mathrm{L}^{-1}$, próxima à concentração teórica de $6 \mathrm{mg} \cdot \mathrm{L}^{-1}$. Assim, como o frasco foi trocado a cada 3 dias, foi considerado que o mesmo não sofreu degradação nesse período de tempo.

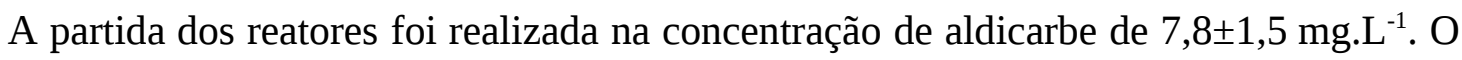
tempo de operação nesta etapa se estendeu além do esperado em função de problemas no HPLC, o que impossibilitou a análise em tempo real das amostras retiradas dos reatores. Entretanto, o monitoramento foi acompanhado por outras variáveis, como composição do biogás, por exemplo.

Nas Figuras 5.7 a 5.13 é mostrada a variação da concentração de aldicarbe, sulfato, nitrato, relação entre alcalinidade intermediária e alcalinidade parcial (AI/AP), pH e concentração e composição do biogás no período para os três reatores. 


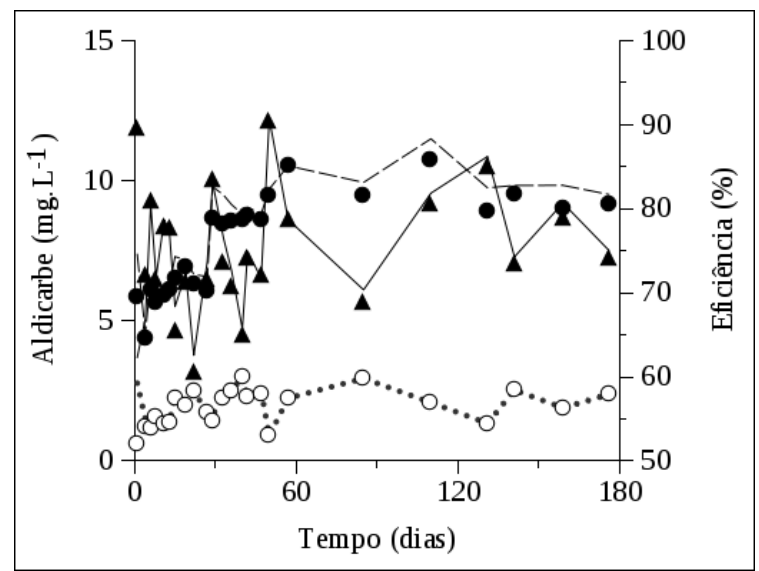

(a)

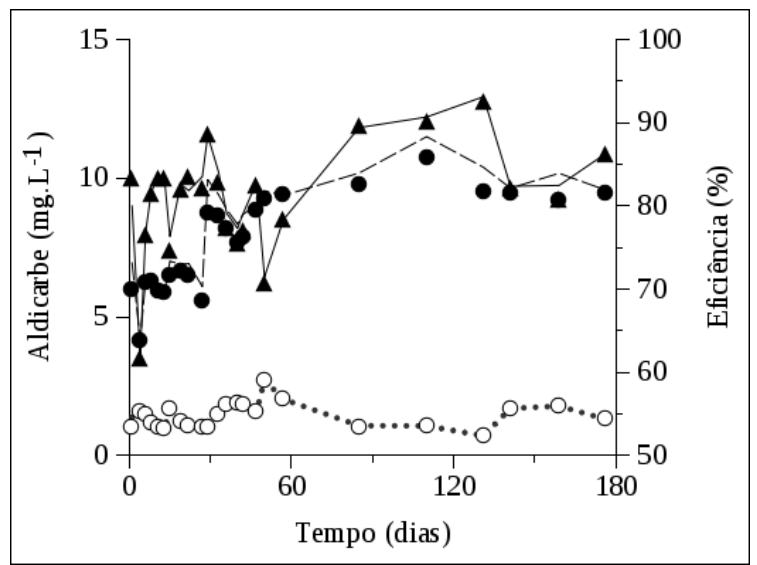

(b)

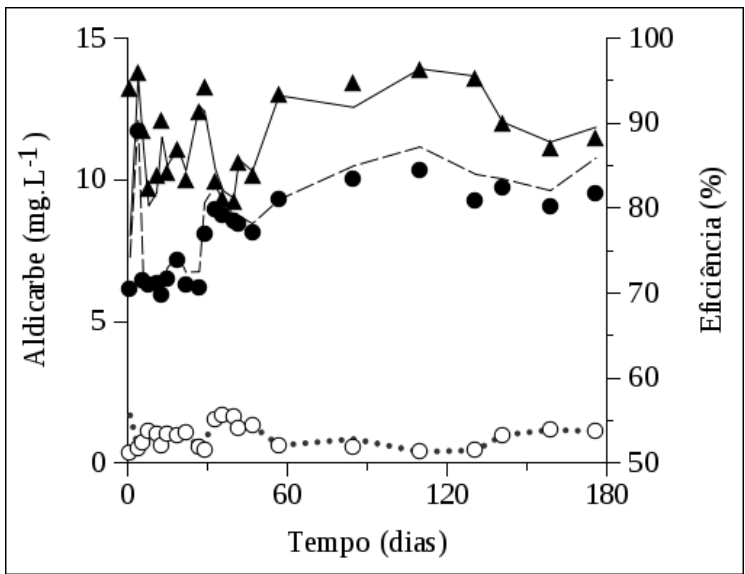

(c)

Figura 5.7. Variação da concentração de aldicarbe, concentração de aldicarbe total e eficiência de remoção no período de partida sob condições metanogênicas (a), sulfetogênicas (b) e desnitrificantes (c).

[Notação: •, aldicarbe afluente; ○, aldicarbe efluente; ---, aldicarbe total afluente; ….., aldicarbe total efluente;

$\boldsymbol{\Delta}$, eficiência de remoção de aldicarbe; —_, eficiência de remoção de aldicarbe total.]

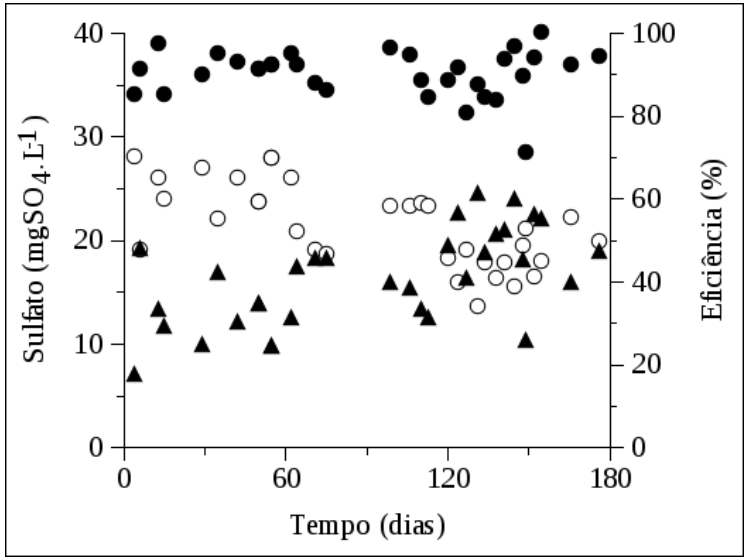

Figura 5.8. Variação da concentração de sulfato e eficiência de conversão no período de partida sob condições sulfetogênicas.

[Notação: •, sulfato afluente; ○, sulfato efluente; $\boldsymbol{\Lambda}$, eficiência de conversão de sulfato.] 


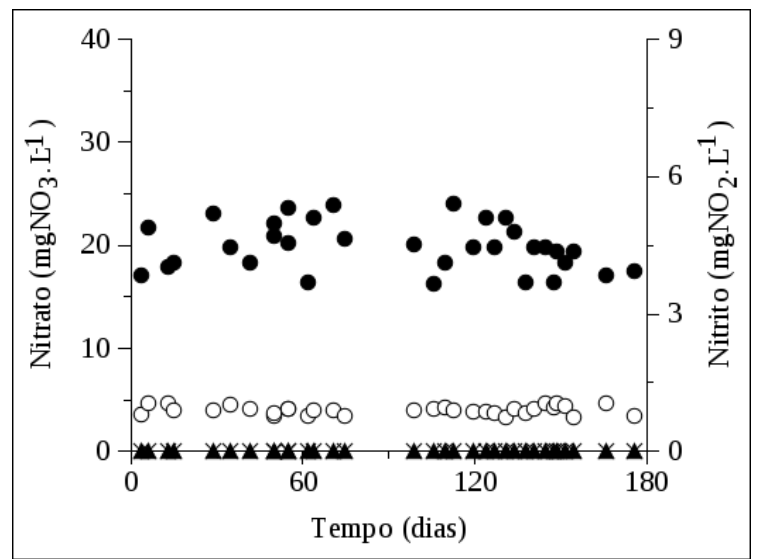

Figura 5.9. Variação da concentração de nitrato e nitrito no período de partida sob condições desnitrificantes.

[Notação: •, nitrato afluente; ○, nitrato efluente; $\boldsymbol{\Delta}$, nitrito afluente; $\times$, nitrito efluente.]

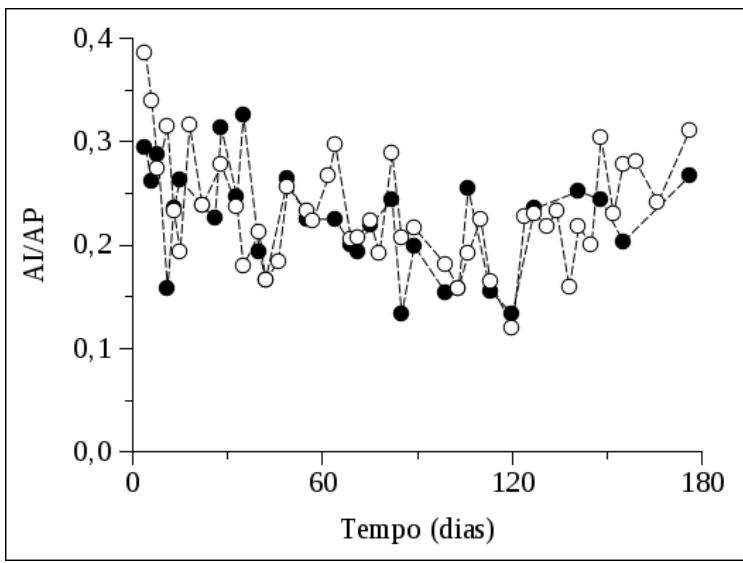

(a)

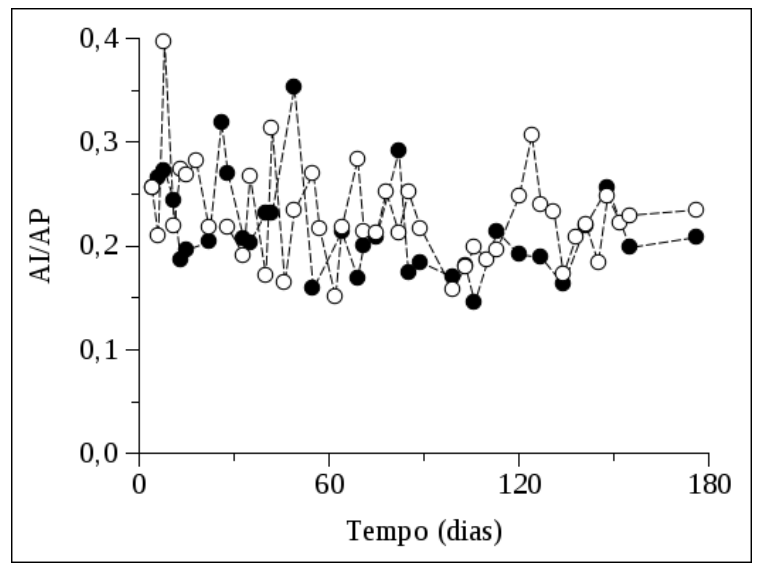

(b)

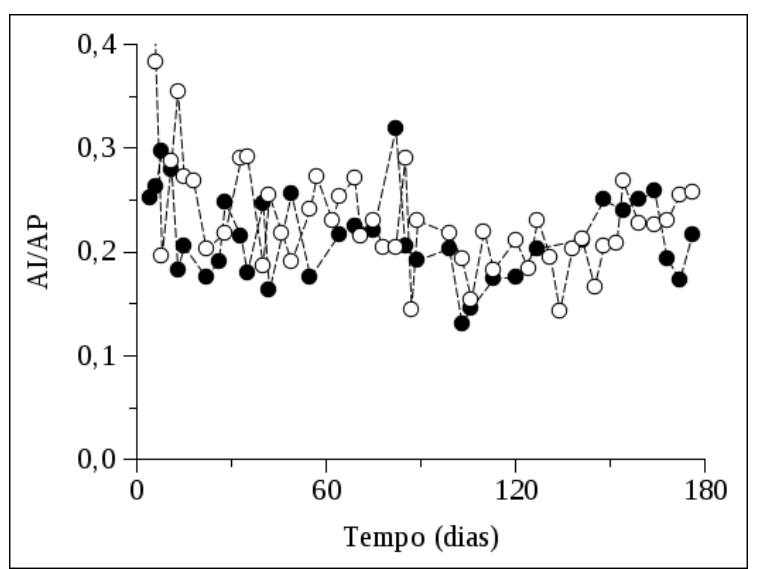

(c)

Figura 5.10. Variação da relação AI/AP no período de partida sob condições metanogênicas (a), sulfetogênicas (b) e desnitrificantes (c).

[Notação: •, afluente; ○, efluente.] 


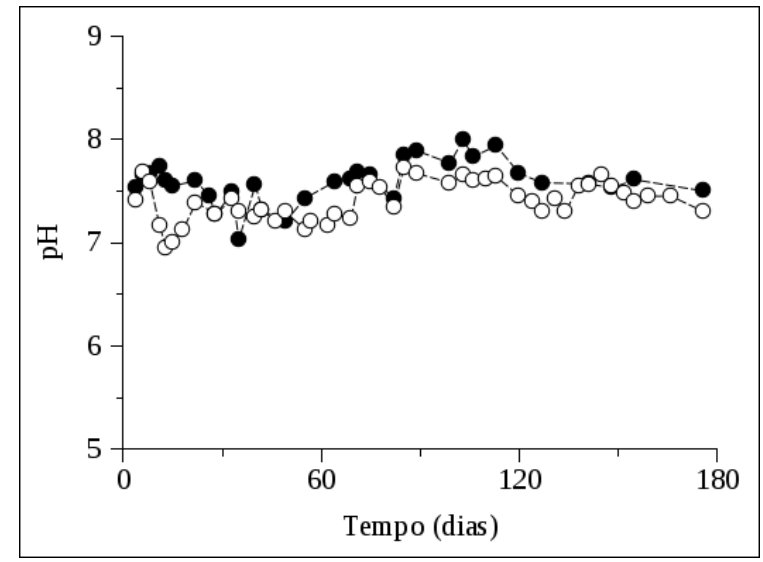

(a)

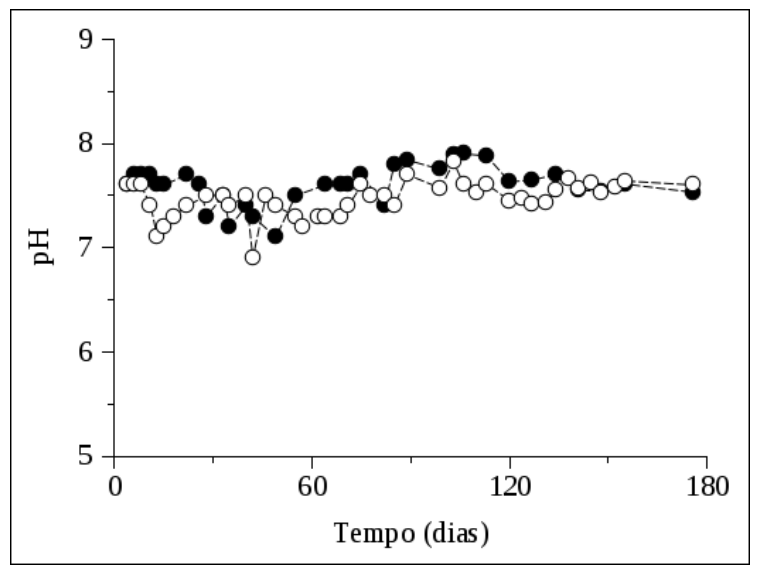

(b)

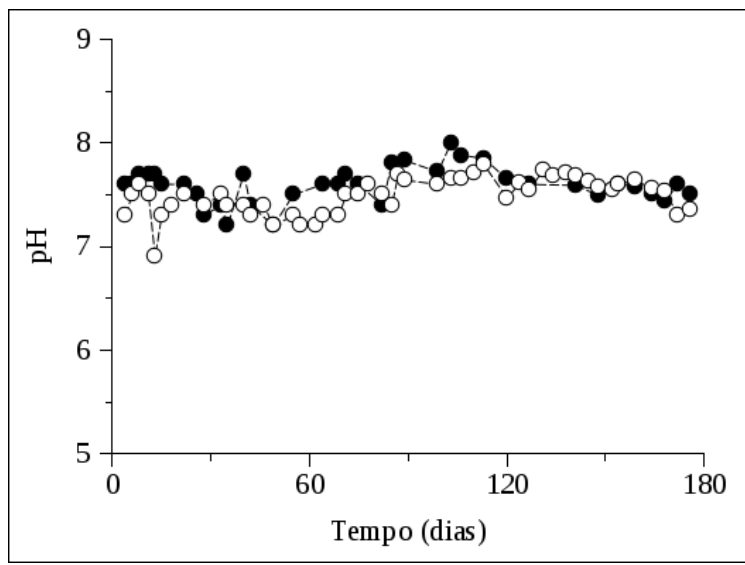

(c)

Figura 5.11. Variação do pH no período de partida sob condições metanogênicas (a), sulfetogênicas (b) e desnitrificantes (c).

[Notação: •, pH afluente; ○, pH efluente.]

Os tempos de partida foram semelhantes nos três reatores, de aproximadamente 180 dias. Para a definição do mesmo, estabeleceu-se que, a partir da ocorrência do equilíbrio dinâmico aparente (condição em que há pouca variação dos parâmetros monitorados), haveria o seu estabelecimento. Assim, em função dos dados experimentais, o monitoramento das concentrações de metano e gás carbônico no biogás se apresentou fundamental para avaliação desta etapa.

Até o $30^{\circ}$ dia, nota-se que a concentração de aldicarbe esteve abaixo da inicialmente estabelecida (10 mg. $\left.\mathrm{L}^{-1}\right)$. Nesse período foram detectados problemas no equipamento (instabilidade no detector de UV) que ocasionaram determinações incorretas na solução estoque obtida da extração do aldicarbe do produto comercial. Assim, após a resolução dos problemas, a concentração de aldicarbe foi corretamente estabelecida. 


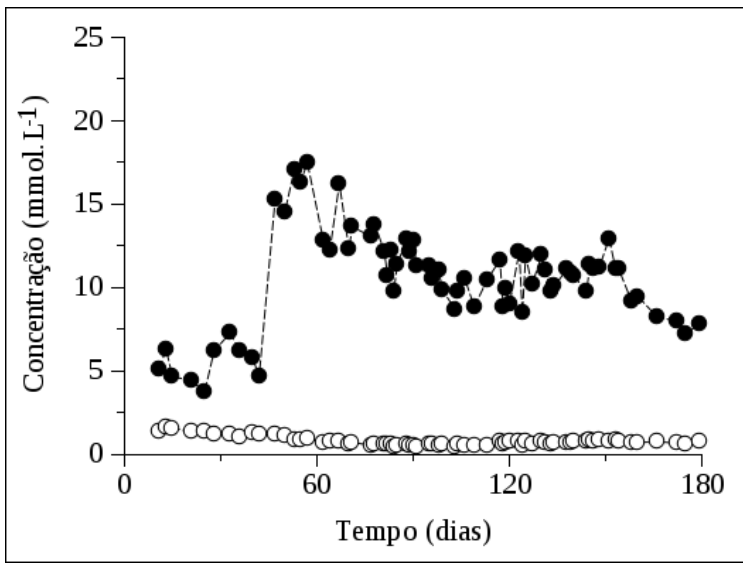

(a)

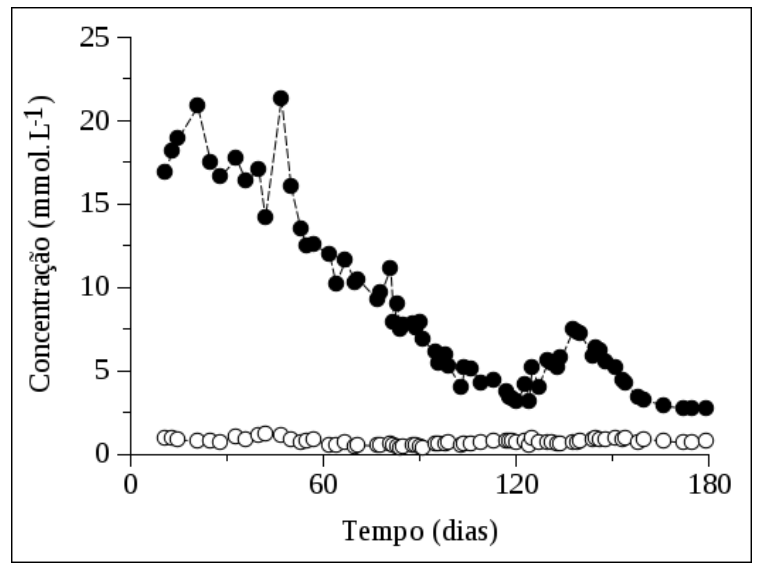

(b)

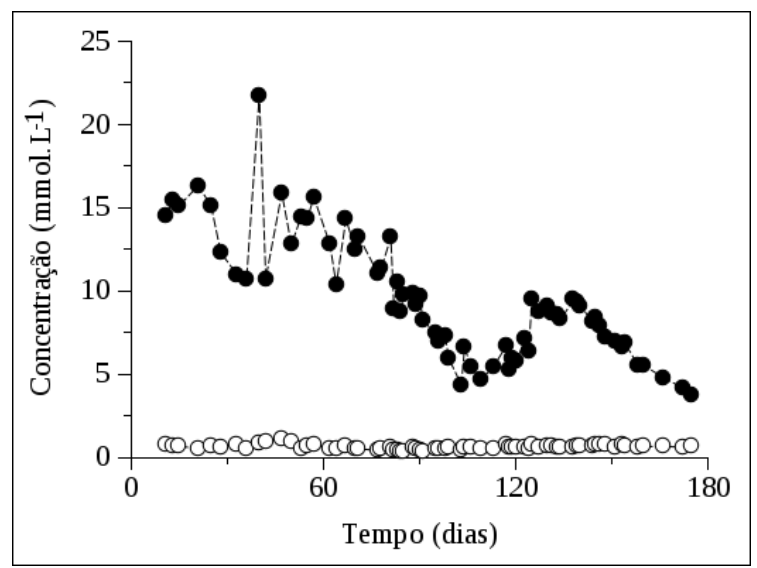

(c)

Figura 5.12. Variação da concentração de metano e gás carbônico no biogás no período de partida sob condições metanogênicas (a), sulfetogênicas (b) e desnitrificantes (c).

[Notação: •, metano; ○, gás carbônico.]

No que diz respeito à degradação de aldicarbe, verificou-se ligeira estabilidade dos valores da concentração de aldicarbe no efluente nos três reatores, desde o início do processo. No reator metanogênico, nos primeiros 45 dias, constatou-se que a concentração de metano no biogás foi próxima a $5 \mathrm{mmol} . \mathrm{L}^{-1}$, inferiores aos verificados no reator sulfetogênico e desnitrificante (17,5 e 15 mmol. $\mathrm{L}^{-1}$, respectivamente). Nos sistemas sulfetogênico e desnitrificante, após o $45^{\circ}$ dia, houve ligeiro aumento da eficiência de remoção. Essa observação corresponde ao início da redução da concentração de metano do biogás nestes sistemas. Concomitantemente, nesse mesmo período, há aumento expressivo da concentração de metano no sistema metanogênico, com redução posterior. Isso pode sugerir maior sensibilidade do sistema metanogênico ao aldicarbe na fase inicial de adaptação do processo de degradação ou até mesmo a importância de outros organismos na degradação inicial do aldicarbe e conseqüente redução da toxicidade às arquéias metanogênicas. $\mathrm{O}$ aumento expressivo na concentração de metano pode ter sido resposta ao aumento da concentração de 
aldicarbe no afluente (em função dos problemas do equipamento analítico) ou mesmo à adaptação da biomassa ao composto, semelhante à uma fase "lag".

É interessante observar que, no decorrer do período de partida, a eficiência de remoção de aldicarbe total atinge os mesmos valores da remoção de aldicarbe, o que reflete a ausência de sulfóxido e sulfona de aldicarbe nas amostras do efluente dos reatores. Isto indica que, provavelmente, a rota metabólica tenha sido desviada para a formação de oximas e nitrilas ao longo do estabelecimento do processo.

A conversão de sulfato no reator sulfetogênico foi estável nos primeiros 80 dias de operação (valor médio de 34\%), com ligeira elevação posterior (valor médio de 46,5\%). A conversão de nitrato se apresentou estável desde o início do processo, com pouca variação ao longo do tempo, com valor médio de $80 \%$ no período.

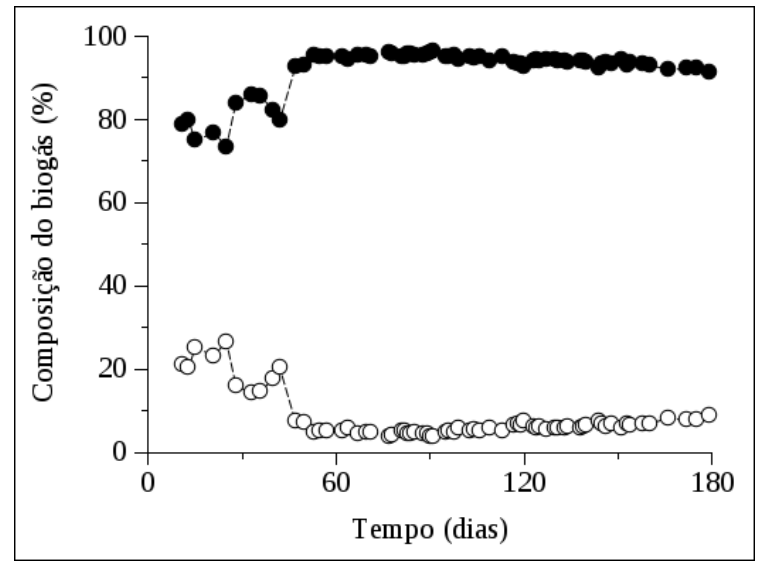

(a)

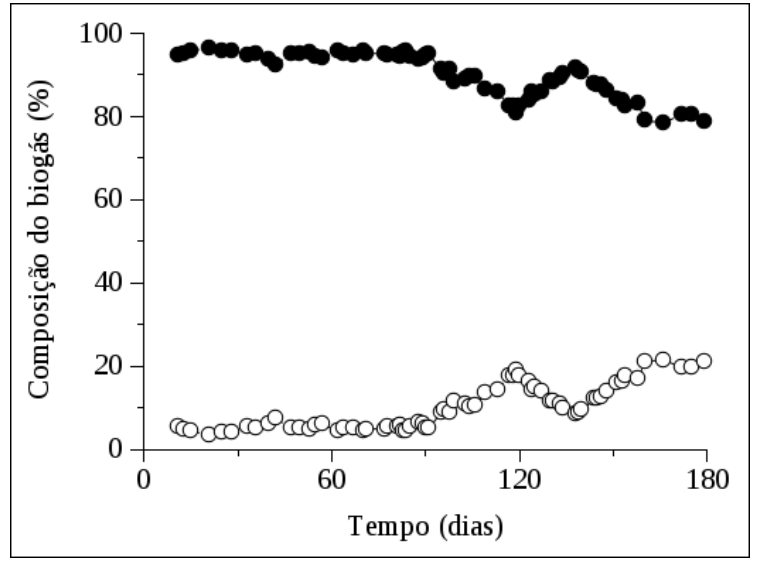

(b)

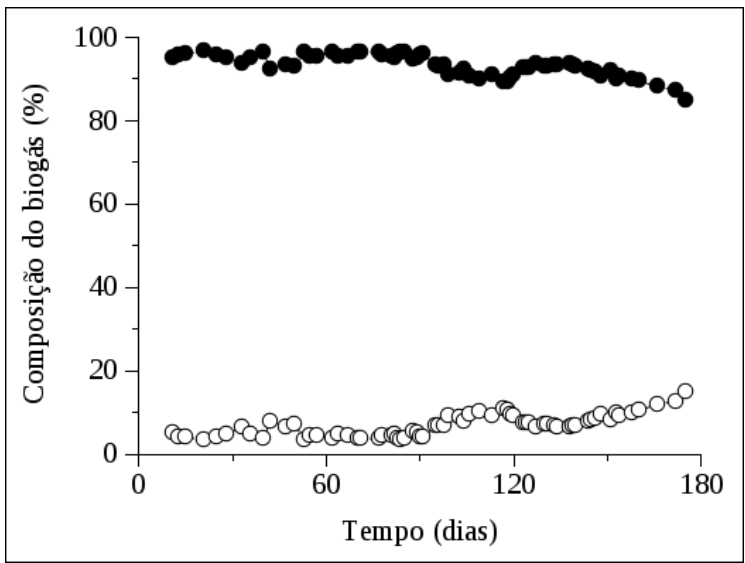

(c)

Figura 5.13. Variação da composição do biogás no período de partida no sob condições metanogênicas (a), sulfetogênicas (b) e desnitrificantes (c).

[Notação: •, metano; o, gás carbônico.] 
De acordo com Ripley, Boyle e Converse (1986), a alcalinidade parcial (AP) (correspondente à titulação até o pH de 5,75), praticamente equivale à alcalinidade a bicarbonato (AB) enquanto que a alcalinidade intermediária (AI) (correspondente à titulação até o $\mathrm{pH}$ de 4,3), praticamente equivale à alcalinidade dos ácidos voláteis. O uso da relação AI/AP pode ser uma ferramenta importante para controle de processos anaeróbios. Embora Ripley, Boyle e Converse (1986) estabeleçam que valores de AI/AP acima de 0,3 indiquem distúrbios no processo de digestão anaeróbia, Foresti (1994) salienta a necessidade de prudência no emprego deste parâmetro visto que a estabilização do processo pode se dar em valores diferentes de 0,3.

Como a ocorrência de AI corresponde à presença de ácidos voláteis e estes não estavam presentes no meio sintético utilizado (em função da sua composição), provavelmente algum componente interferiu no método, sendo analiticamente determinado como ácidos voláteis. Damasceno (2004) também fez essa constatação quando o mesmo método analítico foi empregado em amostras de soro de queijo diluído. Nesse contexto, optou-se por fazer a análise do processo pela comparação direta das amostras do efluente com o afluente com o objetivo de se avaliar um possível incremento de ácidos no efluente ou consumo da alcalinidade a bicarbonato, o que causaria aumento na relação AI/AP. No reator metanogênico verificou-se redução gradual dos valores de AI/AP nas amostras do efluente quando comparadas às amostras do afluente ao longo do período de partida (Figura 5.10.a). No reator sulfetogênico e desnitrificante verificou-se ligeiro aumento de AI/AP ao final do processo (Figura 5.10.b e Figura 5.10.c). Em todos reatores observou-se que, com o decorrer do tempo, os valores de AI/AP nas amostras do afluente e do efluente foram semelhantes, o que também é um indicativo de estabilização do processo de degradação. A estabilidade da AI/AP foi evidenciada no $\mathrm{pH}$ visto que em todos reatores sofreu poucas alterações com valores muito próximos das amostras do afluente e do efluente.

Pela Figura 5.12 verifica-se o estabelecimento do período de partida, com migração do sistema metanogênico para os sistemas sulfetogênico e desnitrificante. Essa análise fica mais clara quando os dados apresentados nas Figuras 5.17.b, 5.24.b e 5.32.b (para a condição de $\left.10 \mathrm{mg} \cdot \mathrm{L}^{-1}\right)$. Constata-se que, após o período de partida, a concentração de metano e dióxido de carbono permanece aproximadamente estável. Portanto, embora outros parâmetros tenham apresentado estabilidade operacional, o monitoramento da concentração de metano e biogás se mostrou essencial para a definição do período. Essa observação permite concluir que, em sistemas anaeróbios, a definição da partida não pode se basear somente na análise dos parâmetros de forma isolada mas sim no conjunto de parâmetros, principalmente os mais 
sensíveis, como é a composição do gás gerado pelo sistema. Assim, nesse contexto, o tempo de experimentação foi importante para o correto estabelecimento das condições de oxidação desejadas.

No que diz respeito à composição do biogás (considerando-se o mesmo composto somente por metano e gás carbônico), observou-se tendência à estabilização no sistema metanogênico (valores médios de $80 \%$ para metano e 20\% para gás carbônico) e ligeira redução de metano no sistema sulfetogênico (valores médios de 91\% para metano e 9\% para gás carbônico) e no sistema desnitrificante (valores médios de 94\% para metano e 6\% para gás carbônico).

\subsubsection{Reator metanogênico}

Nas Figuras 5.14 a 5.18 são apresentadas, respectivamente, as variações da concentração de aldicarbe, relação entre alcalinidade intermediária e alcalinidade parcial (AI/ AP), $\mathrm{pH}$, concentração e percentual dos componentes do biogás ao longo do tempo para as diferentes condições testadas. Na Tabela 5.7 são mostrados os valores médios das concentrações de aldicarbe e seus metabólitos. Os perfis temporais da concentração de aldicarbe e metabólitos são mostrados na Figura 5.19. Na Tabela 5.8 são mostrados os parâmetros cinéticos aparentes ajustados aos dados experimentais.

Nas amostras do afluente, parte do aldicarbe foi convertida a sulfóxido de aldicarbe (5,4\% na média) e não foi detectada sulfona de aldicarbe. Nas amostras do efluente não foram detectados sulfóxido e sulfona de aldicarbe durante todos os ensaios, sendo um indicativo de que condições anaeróbias estavam estabelecidas. Assim sendo, as eficiências de remoção de aldicarbe e aldicarbe total foram idênticas.

Quando submetido à variação afluente da concentração de aldicarbe (Figura 5.14), houve rápida estabilização das variáveis monitoradas, demonstrando a robustez do RAHLF. Para as concentrações de 5 e 10 mg.L $\mathrm{L}^{-1}$, observou-se no RAHLF eficiências de remoção de aldicarbe elevadas, 93,2 e 88,9\%, respectivamente. A partir do aumento da concentração para 20, 30 e 40 mg. $\mathrm{L}^{-1}$, houve significativa redução para 76,5, 71,6 e 65,1\%, respectivamente.

A relação AI/AP sofreu pouca variação nas amostras do efluente em relação às amostras do afluente, mesmo com o aumento da concentração (Figura 5.15). Conseqüentemente, o pH permaneceu estável (Figura 5.16), com valores médios próximos a 7,5 em amostras do afluente e do efluente. 


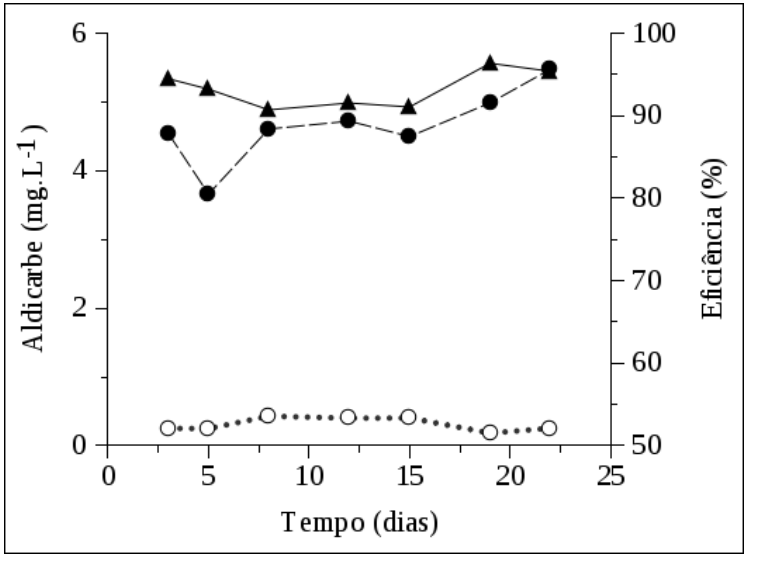

(a)

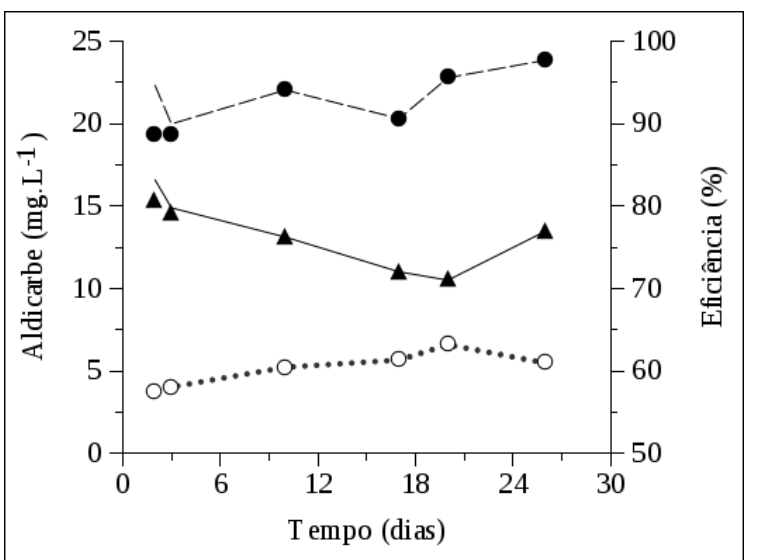

(c)

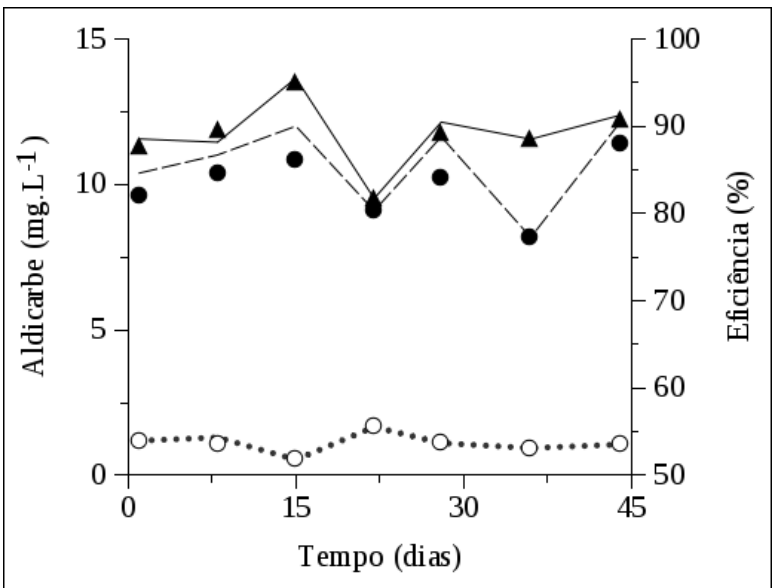

(b)

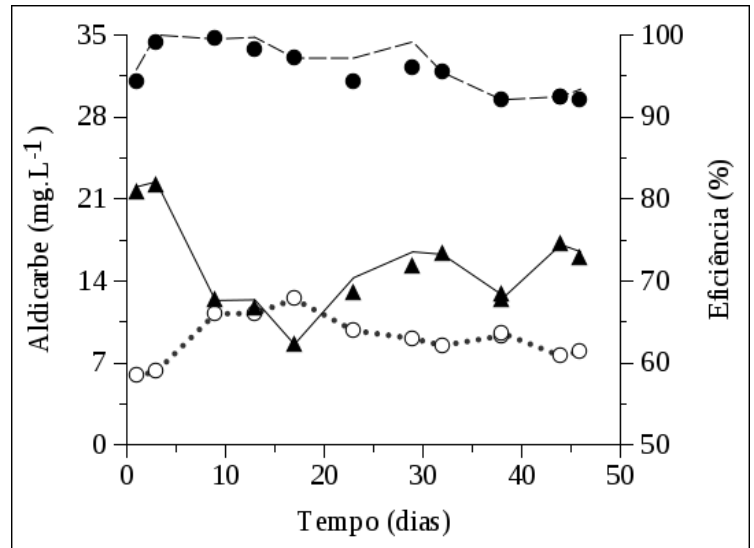

(d)

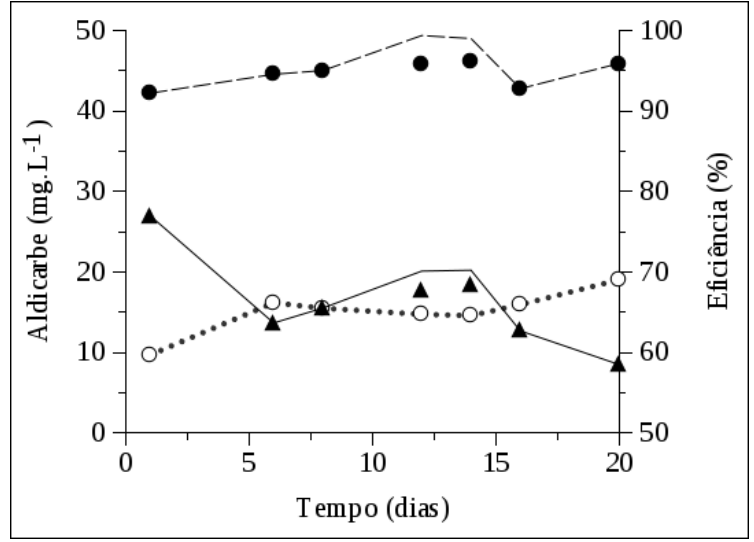

(e)

Figura 5.14. Variação da concentração de aldicarbe, concentração de aldicarbe total e eficiência de remoção no Ensaio 5 (a), 10 (b), 20 (c), 30 (d) e 40 (e) sob condições metanogênicas.

[Notação: •, aldicarbe afluente; ○, aldicarbe efluente; ---, aldicarbe total afluente; $\cdots \cdot \cdot \cdot$, aldicarbe total efluente; ム , eficiência de remoção de aldicarbe; — - eficiência de remoção de aldicarbe total.] 


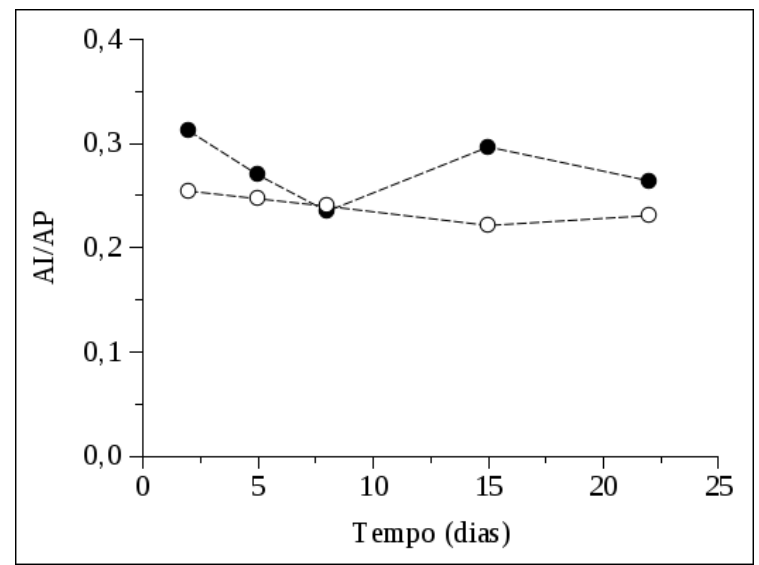

(a)

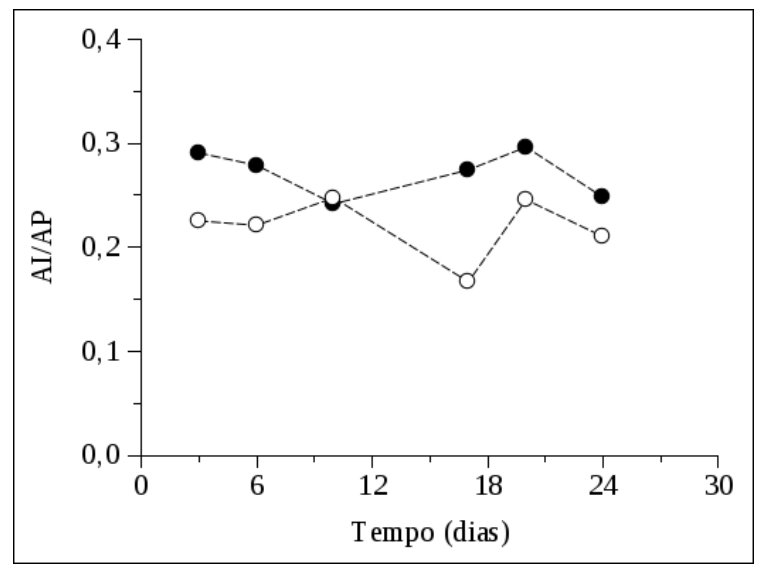

(c)

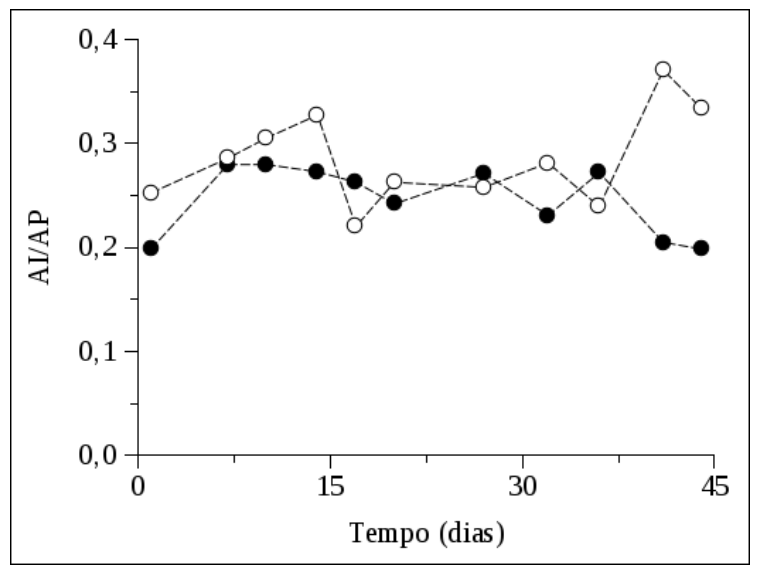

(b)

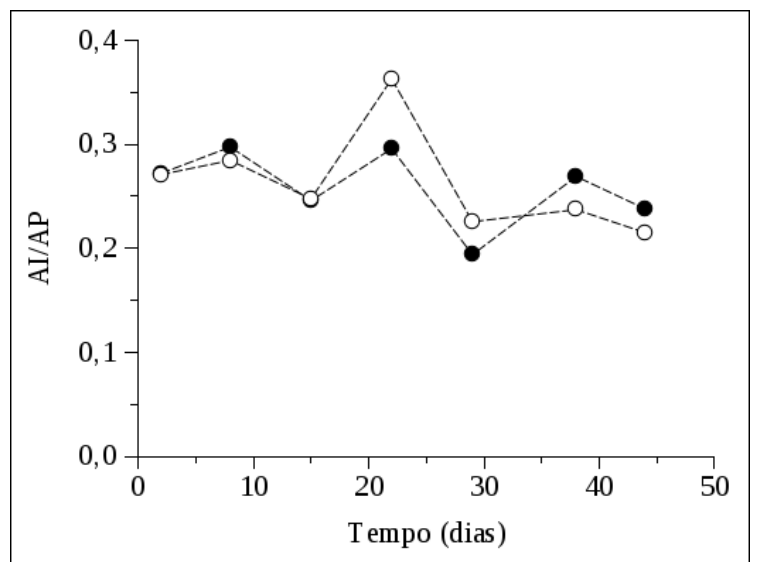

(d)

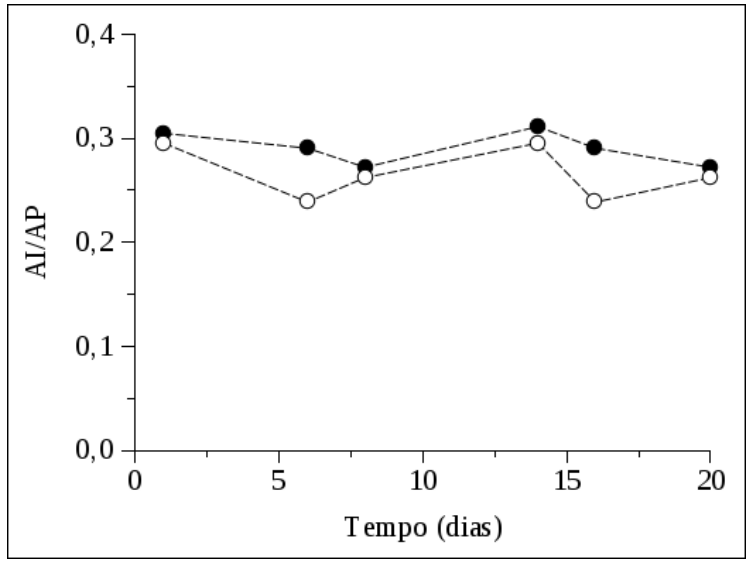

(e)

Figura 5.15. Variação da relação AI/AP no Ensaio 5 (a), 10 (b), 20 (c), 30 (d) e 40 (e) sob condições metanogênicas.

[Notação: •, afluente; ○, efluente.] 


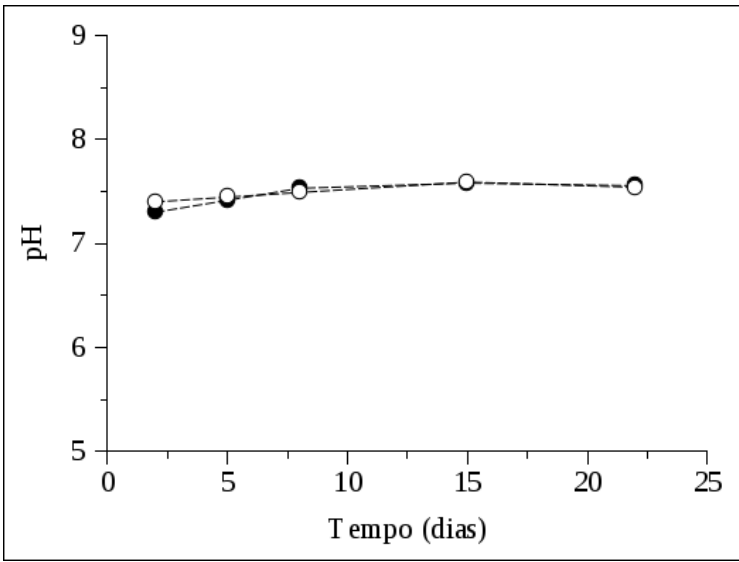

(a)

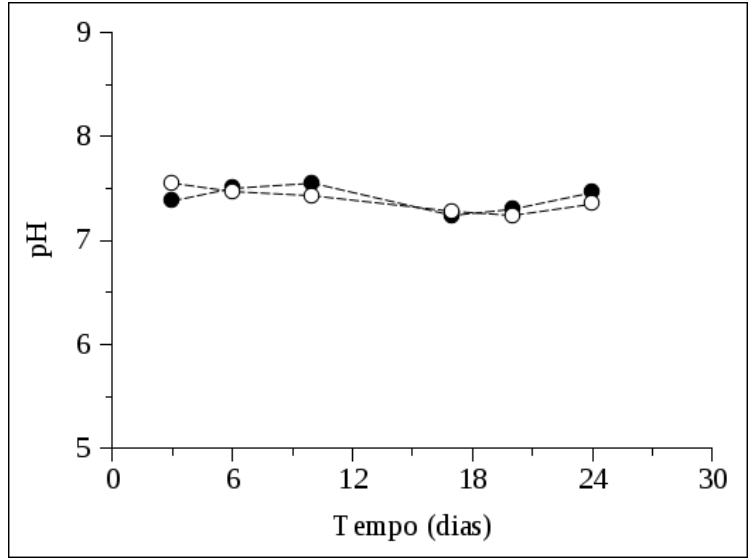

(c)

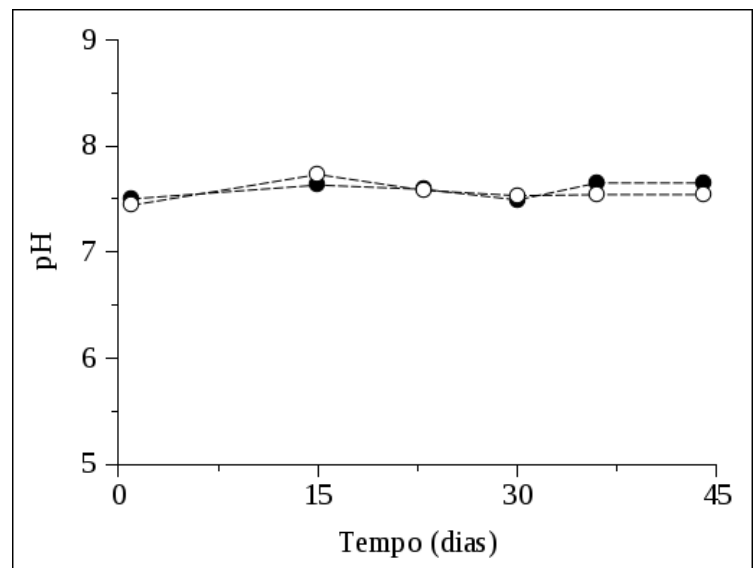

(b)

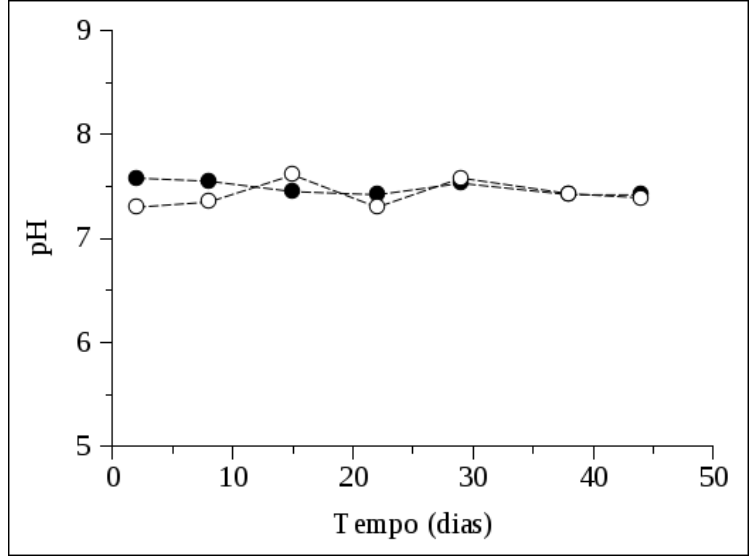

(d)

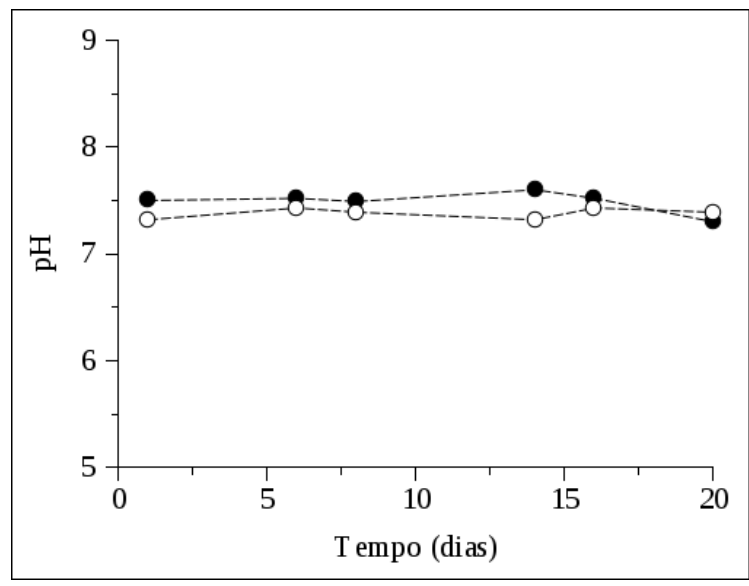

(e)

Figura 5.16. Variação do pH no Ensaio 5 (a), 10 (b), 20 (c), 30 (d) e 40 (e) sob condições metanogênicas.

[Notação: •, afluente; o, efluente.] 


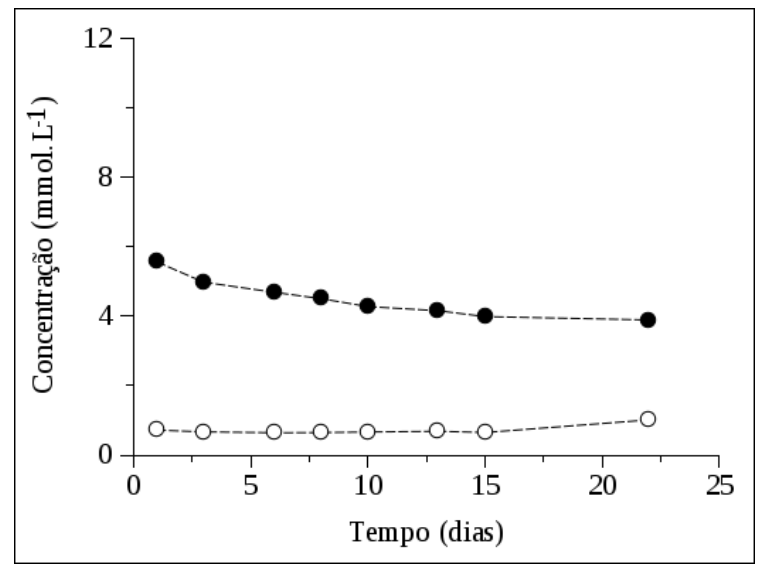

(a)

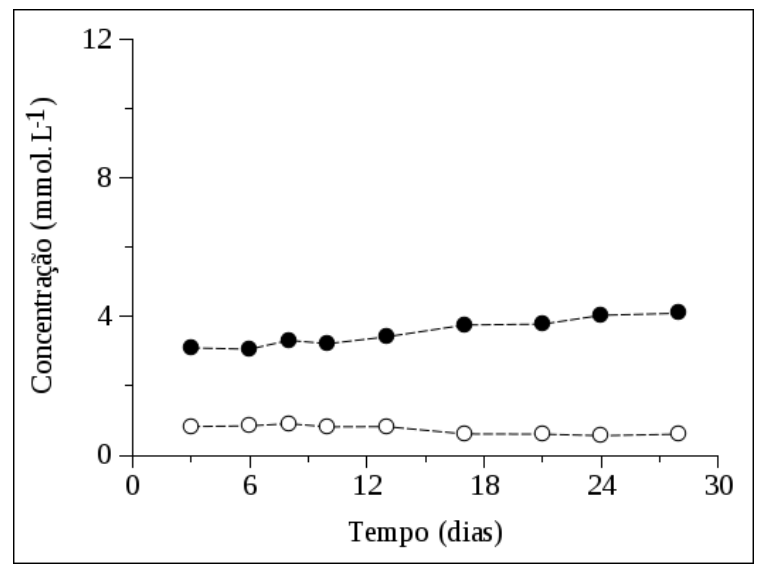

(c)

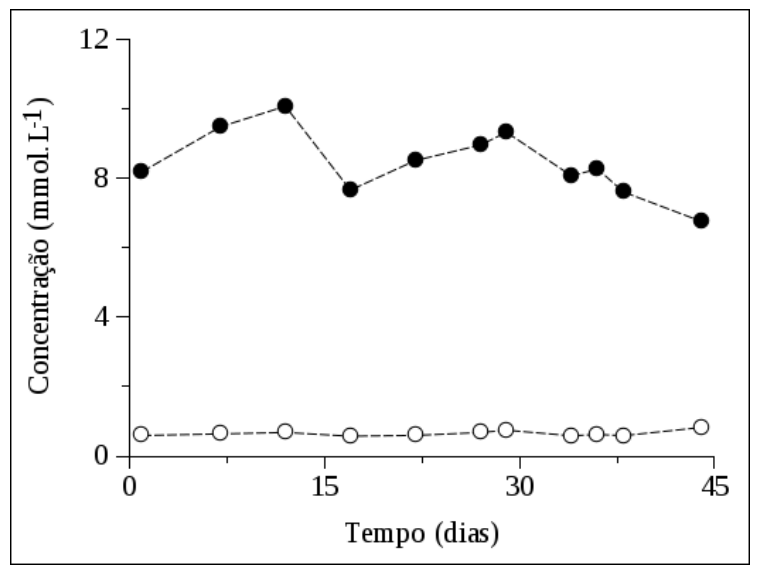

(b)

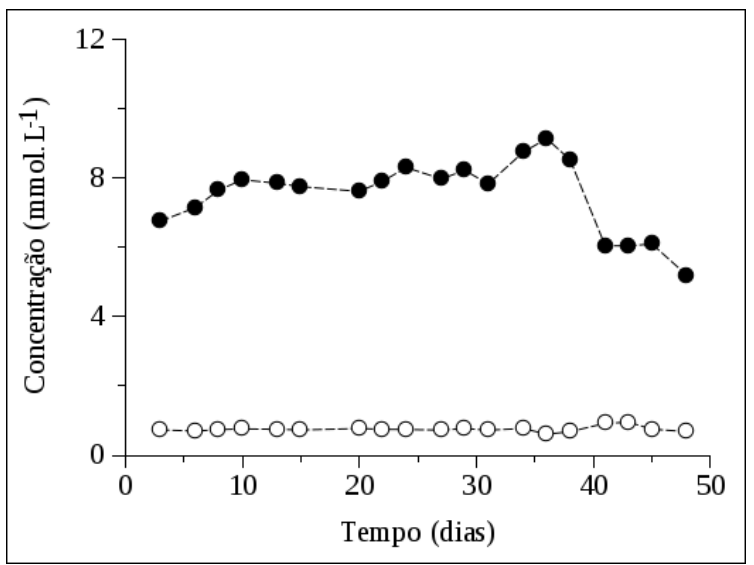

(d)

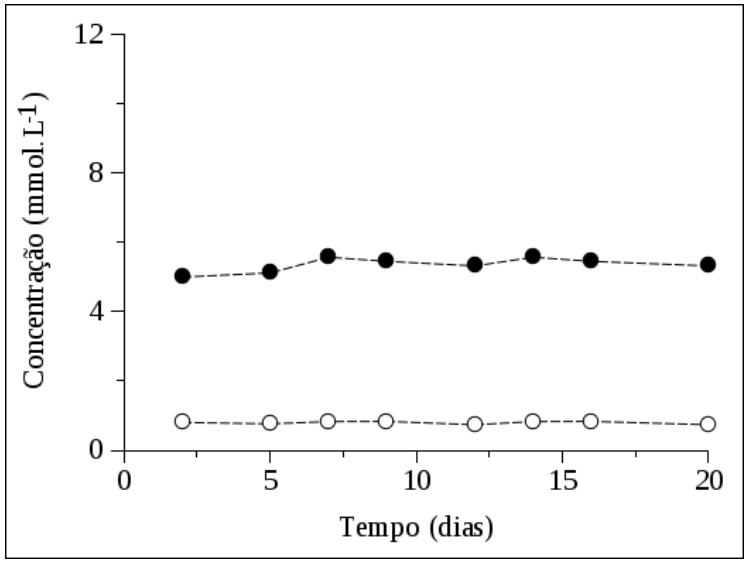

(e)

Figura 5.17. Variação da concentração de metano e gás carbônico no biogás no Ensaio 5 (a), 10 (b), 20 (c), 30 (d) e 40 (e) sob condições metanogênicas.

[Notação: •, metano; o, gás carbônico.] 


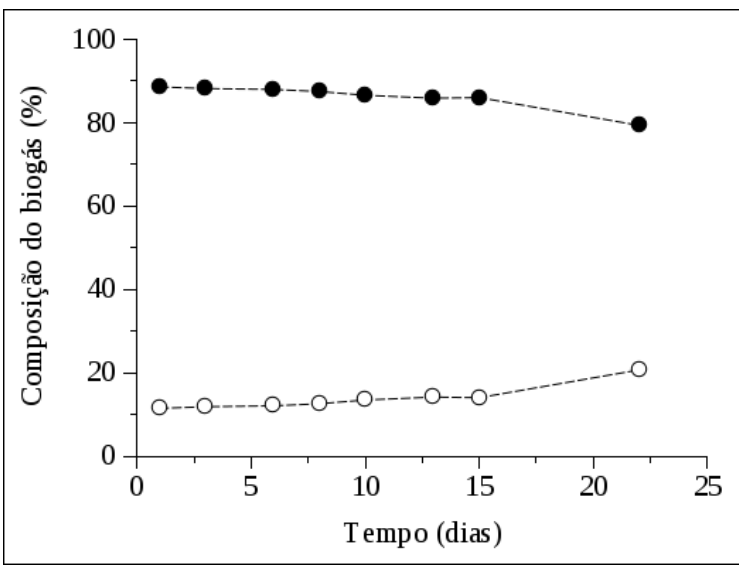

(a)

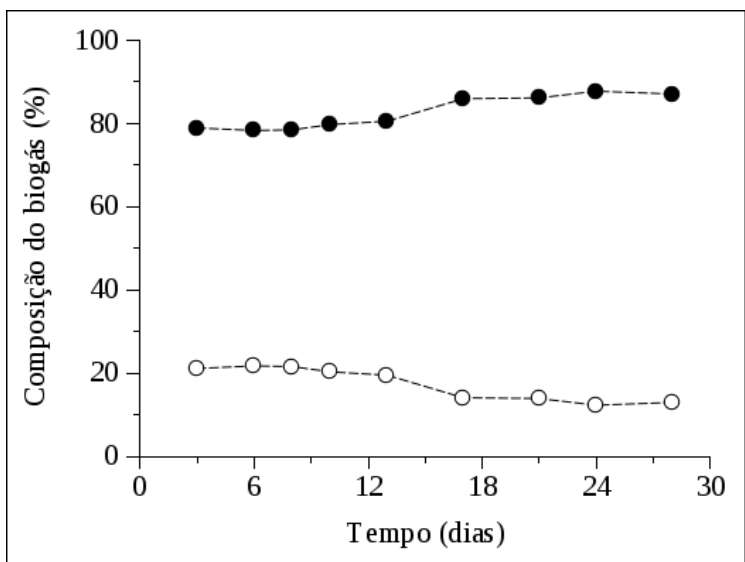

(c)

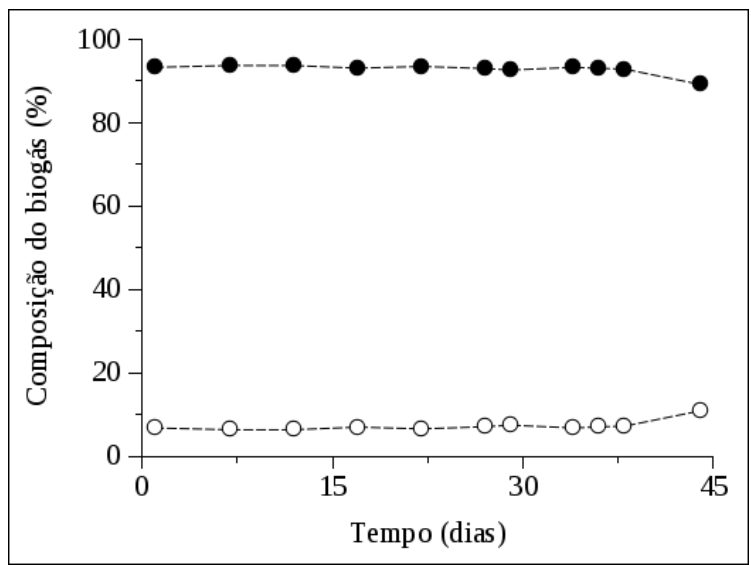

(b)

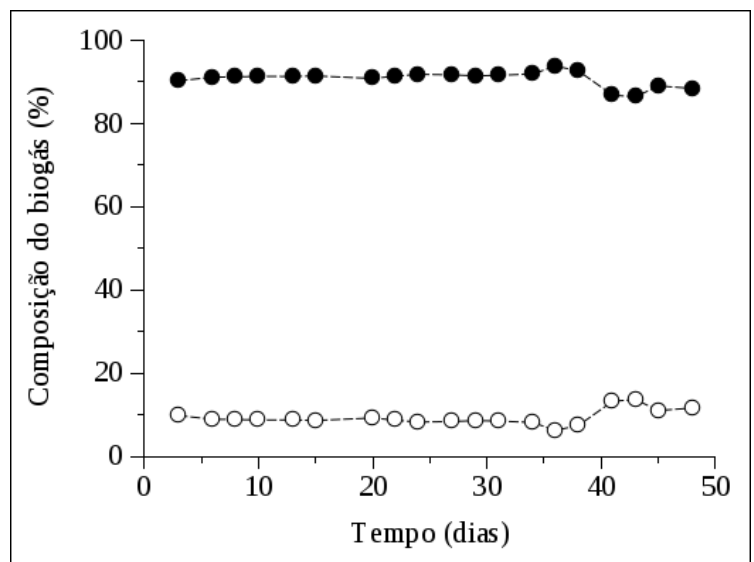

(d)

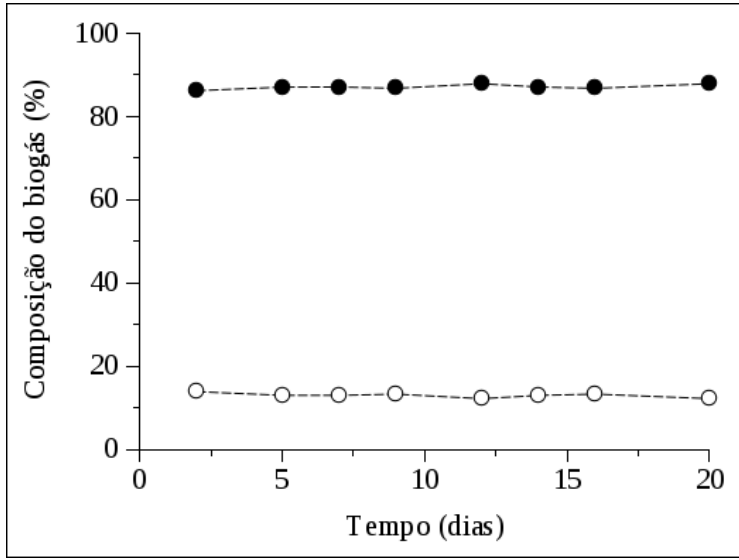

(e)

Figura 5.18. Variação da composição do biogás no Ensaio 5 (a), 10 (b), 20 (c), 30 (d) e 40 (e) sob condições metanogênicas.

[Notação: •, metano; ○, gás carbônico.] 
A concentração de metano e dióxido de carbono foi baixa, variando de 3,5 a 10,9 mmol. $\mathrm{L}^{-1}$ e 0,7 a 0,8 mmol. $\mathrm{L}^{-1}$, respectivamente. Estes valores podem ser reflexo da alimentação com baixa concentração de fonte de carbono. A concentração de dióxido de carbono foi semelhante em todas as concentrações afluentes, mostrando não sofrer efeito direto da variação da concentração afluente (Figura 5.17). No que diz respeito à composição do biogás, o metano foi determinado como sendo o principal componente do mesmo, variando de 82,5 a 94,0\%. O percentual de dióxido de carbono 6,0 a 17,5\% (Figura 5.18).

Tabela 5.7 - Valores médios da concentração de aldicarbe, seus metabólitos e aldicarbe total e eficiências de remoção para diferentes condições avaliadas no reator metanogênico.

\begin{tabular}{|c|c|c|c|c|c|c|}
\hline & \multirow{2}{*}{ Variável } & \multicolumn{5}{|c|}{ Ensaio* } \\
\hline & & 5 & 10 & 20 & 30 & 40 \\
\hline \multirow{4}{*}{ 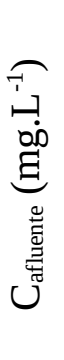 } & Aldicarbe & $4,6 \pm 0,6^{(7)}$ & $10,0 \pm 1,1^{(7)}$ & $21,3 \pm 1,9^{(6)}$ & $31,7 \pm 1,9^{(12)}$ & $44,6 \pm 1,6^{(7)}$ \\
\hline & Sulfóxido de aldicarbe & $0,0 \pm 0,0^{(7)}$ & $0,6 \pm 0,4^{(7)}$ & $0,6 \pm 1,2^{(6)}$ & $0,7 \pm 0,8^{(12)}$ & $0,9 \pm 1,6^{(7)}$ \\
\hline & Sulfona de aldicarbe & $0,0 \pm 0,0^{(7)}$ & $0,0 \pm 0,0^{(7)}$ & $0,0 \pm 0,0^{(6)}$ & $0,0 \pm 0,0^{(12)}$ & $0,0 \pm 0,0^{(7)}$ \\
\hline & Aldicarbe total & $4,6 \pm 0,6^{(7)}$ & $10,2 \pm 1,2^{(7)}$ & $21,9 \pm 1,5^{(6)}$ & $32,3 \pm 2,1^{(12)}$ & $45,5 \pm 2,8^{(7)}$ \\
\hline \multirow{4}{*}{ 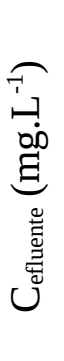 } & Aldicarbe & $0,3 \pm 0,1^{(7)}$ & $1,1 \pm 0,7^{(7)}$ & $5,1 \pm 1,1^{(6)}$ & $8,8 \pm 0,8^{(7)}$ & $16,0 \pm 1,6^{(6)}$ \\
\hline & Sulfóxido de aldicarbe & $0,0 \pm 0,0^{(7)}$ & $0,0 \pm 0,0^{(7)}$ & $0,0 \pm 0,0^{(6)}$ & $0,0 \pm 0,0^{(7)}$ & $0,0 \pm 0,0^{(6)}$ \\
\hline & Sulfona de aldicarbe & $0,0 \pm 0,0^{(7)}$ & $0,0 \pm 0,0^{(7)}$ & $0,0 \pm 0,0^{(6)}$ & $0,0 \pm 0,0^{(7)}$ & $0,0 \pm 0,0^{(6)}$ \\
\hline & Aldicarbe total & $0,3 \pm 0,1^{(7)}$ & $1,1 \pm 0,7^{(7)}$ & $5,1 \pm 1,1^{(6)}$ & $8,8 \pm 0,8^{(7)}$ & $16,0 \pm 1,6^{(6)}$ \\
\hline \multirow{2}{*}{ 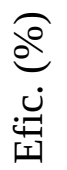 } & Aldicarbe & $93,2 \pm 2,2^{(7)}$ & $88,9 \pm 8,8^{(7)}$ & $76,0 \pm 3,8^{(6)}$ & $71,0 \pm 2,7^{(7)}$ & $64,4 \pm 3,6^{(6)}$ \\
\hline & Aldicarbe total & $93,2 \pm 2,2^{(7)}$ & $89,2 \pm 8,4^{(7)}$ & $76,5 \pm 4,6^{(6)}$ & $71,6 \pm 2,7^{(7)}$ & $65,1 \pm 4,5^{(6)}$ \\
\hline
\end{tabular}

* Os números entre parênteses indicam o número de amostras utilizadas para composição da média.

O ajuste do modelo de primeira ordem com residual aos dados experimentais dos perfis temporais foi adequado em todas as concentrações avaliadas, com valores do coeficiente de correlação de Pearson $\left(r^{2}\right)$ superiores a 0,966 (Tabela 5.8). 


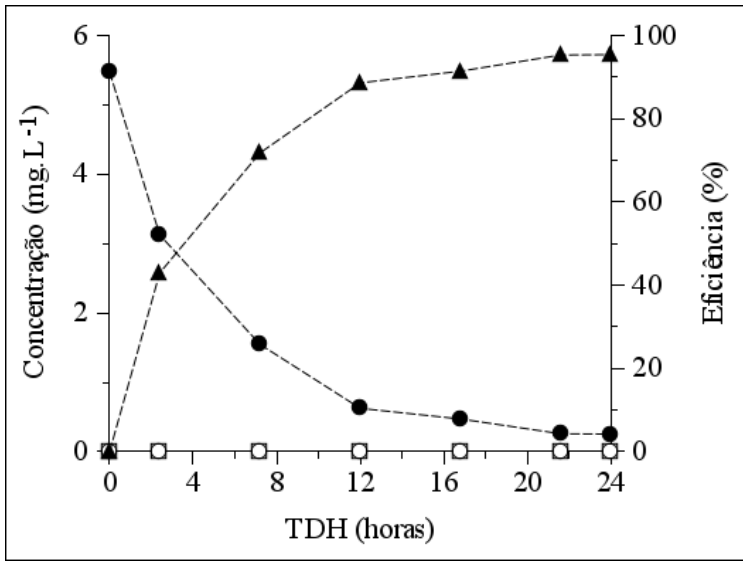

(a)

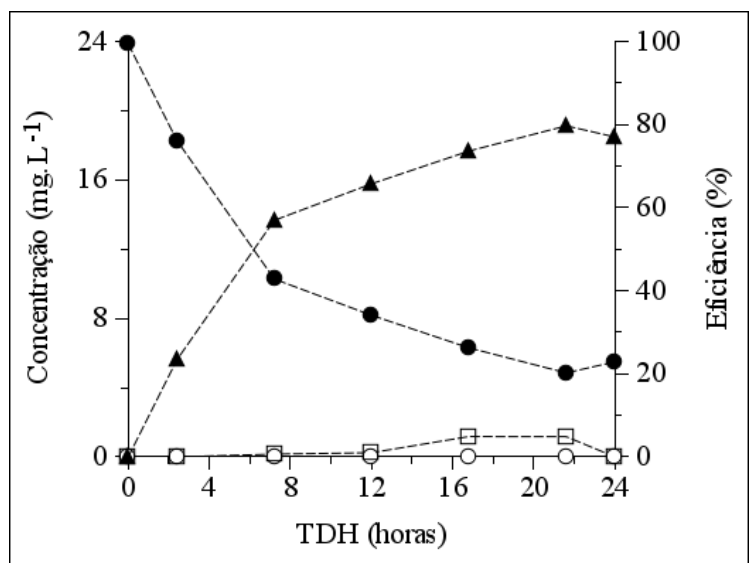

(c)

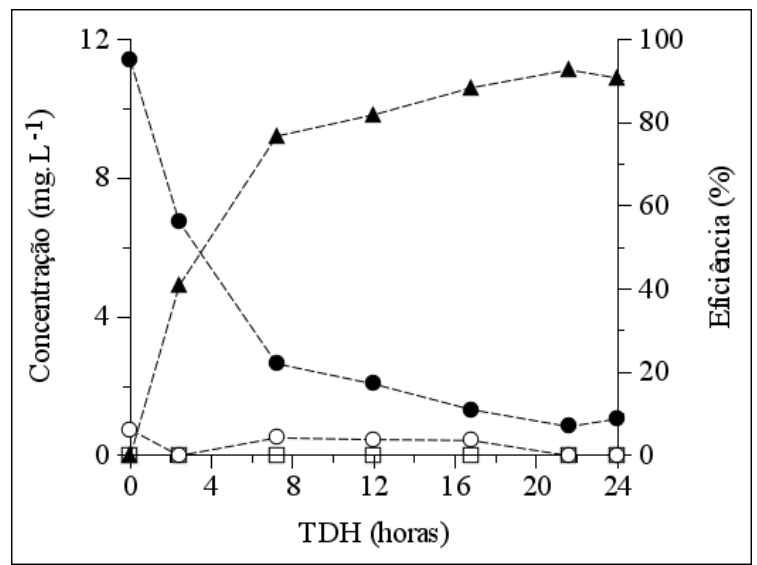

(b)

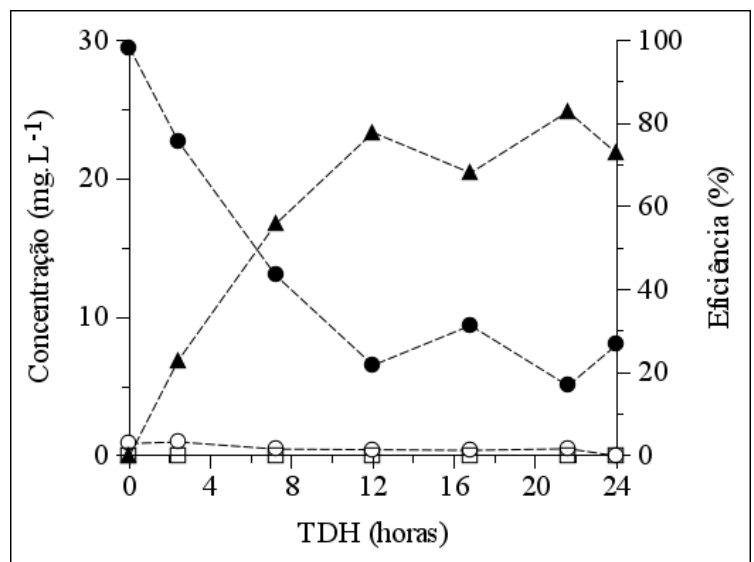

(d)

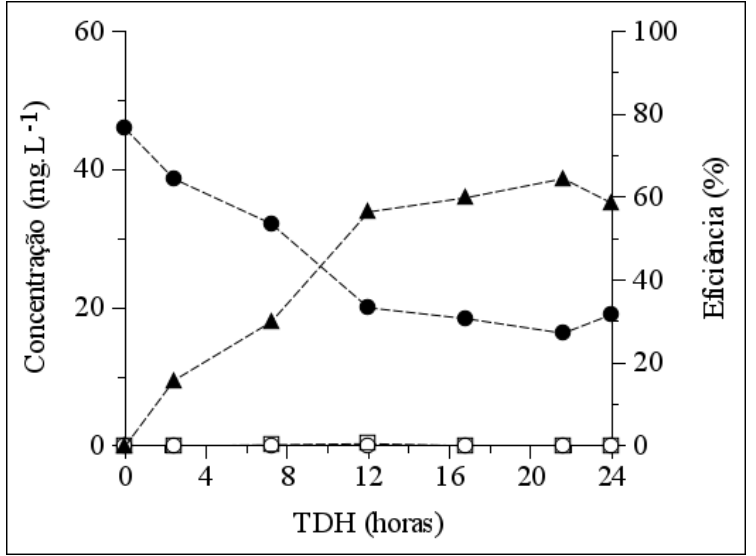

(e)

Figura 5.19. Perfis temporais ao longo do RAHLF da concentração de aldicarbe, sulfóxido de aldicarbe e sulfona de aldicarbe e eficiência de remoção de aldicarbe no Ensaio 5 (a), 10 (b), 20 (c), 30 (d) e 40 (e) sob condições metanogênicas.

[Notação: -•-, aldicarbe; - --, sulfóxido de aldicarbe; - $\square-$, sulfona de aldicarbe;

- $\boldsymbol{\Lambda}$-, eficiência de remoção de aldicarbe.] 
Nos perfis temporais percebe-se a redução da inclinação da curva de concentração de aldicarbe com o aumento da concentração afluente, principalmente a partir de $20 \mathrm{mg} . \mathrm{L}^{-1}$ (Figura 5.19). Assim, o aumento da concentração afluente causou redução gradual na constante cinética aparente de primeira ordem $\left(\mathrm{k}_{1 \mathrm{ap}}\right)$ e aumento na concentração residual de aldicarbe $\left(S_{\min }\right)$ (Tabela 5.8).

Sulfóxido e sulfona de aldicarbe não foram detectados na concentração de 5 mg.L ${ }^{-1}$. Com o aumento de concentração, foram detectados em alguns pontos do perfil, no entanto em baixas concentrações: inferiores a 1,8 e 1,2 mg. $\mathrm{L}^{-1}$ para o sulfóxido e sulfona de aldicarbe, respectivamente.

Tabela 5.8. Parâmetros cinéticos aparentes determinados para diferentes concentrações de aldicarbe sob condições metanogênicas.

\begin{tabular}{ccccc}
\hline $\mathrm{C}_{\text {aldicarbe }}\left(\mathrm{mg} \cdot \mathrm{L}^{-1}\right)$ & $\begin{array}{c}\mathrm{k}_{1 \text { ap }} \\
\left(\mathrm{h}^{-1}\right)\end{array}$ & $\begin{array}{c}\mathrm{S}_{0} \\
\left(\mathrm{mg}_{\left.\text {aldicarbe } . \mathrm{L}^{-1}\right)}\right.\end{array}$ & $\begin{array}{c}\mathrm{S}_{\min } \\
\left(\mathrm{mg}_{\text {aldicarbe. }} \mathrm{L}^{-1}\right)\end{array}$ & $\mathrm{r}^{2}$ \\
\hline 5 & $0,216 \pm 0,020$ & $5,4 \pm 0,1$ & $0,3 \pm 0,1$ & 0,996 \\
10 & $0,246 \pm 0,020$ & $11,4 \pm 0,3$ & $1,1 \pm 0,2$ & 0,996 \\
20 & $0,158 \pm 0,015$ & $24,0 \pm 0,5$ & $4,8 \pm 0,5$ & 0,996 \\
30 & $0,180 \pm 0,050$ & $30,0 \pm 1,9$ & $6,3 \pm 1,5$ & 0,968 \\
40 & $0,109 \pm 0,037$ & $46,3 \pm 2,4$ & $14,3 \pm 3,7$ & 0,966 \\
\hline
\end{tabular}

\subsubsection{Reator sulfetogênico}

A variação da concentração de aldicarbe, sulfato, relação entre alcalinidade intermediária e alcalinidade parcial (AI/AP), pH, concentração de metano e gás carbônico no biogás e composição do biogás é mostrada da Figura 5.20 à 5.25, respectivamente. A Tabela 5.9 mostra os valores médios da concentração de aldicarbe e metabólitos. Os perfis temporais de aldicarbe e sulfato/sulfeto ao longo do RAHLF são mostrados na Figura 5.26 e 5.27, respectivamente. A Tabela 5.10 mostra os parâmetros cinéticos aparentes ajustados aos mesmos. 


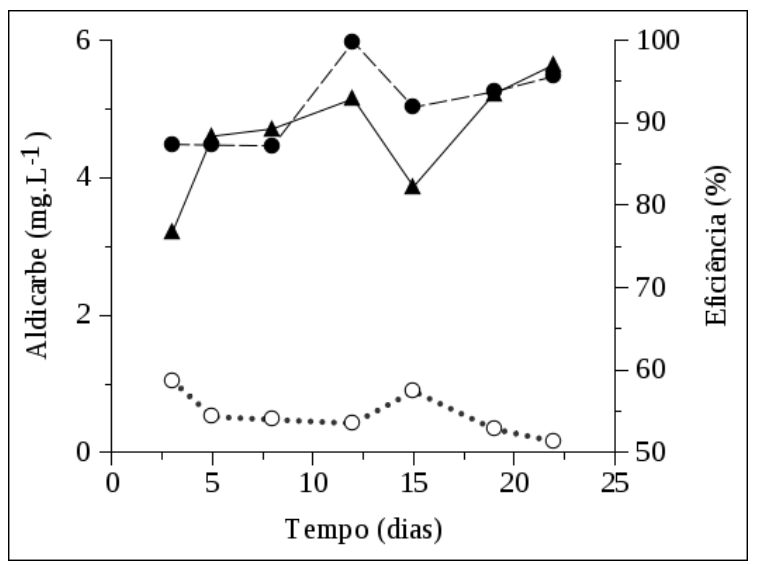

(a)

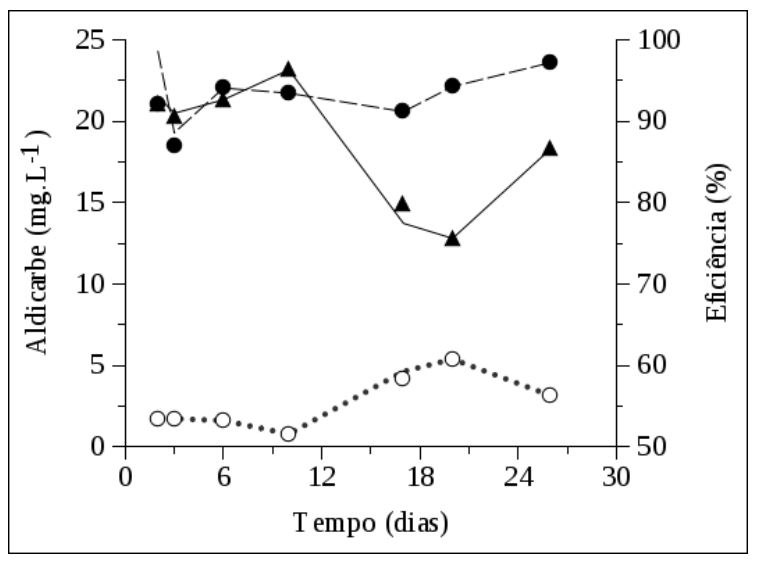

(c)

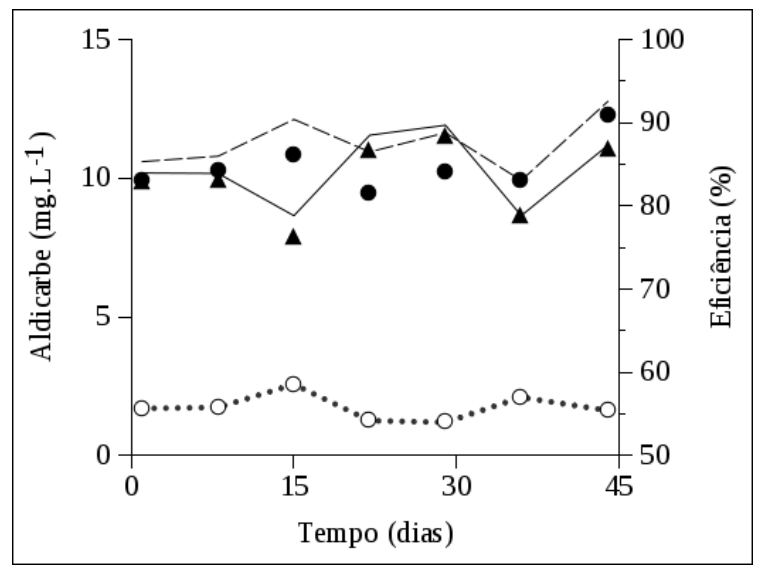

(b)

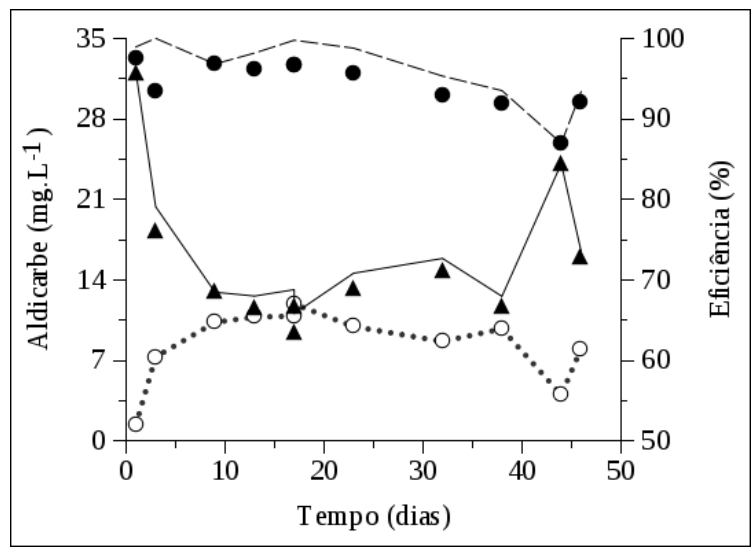

(d)

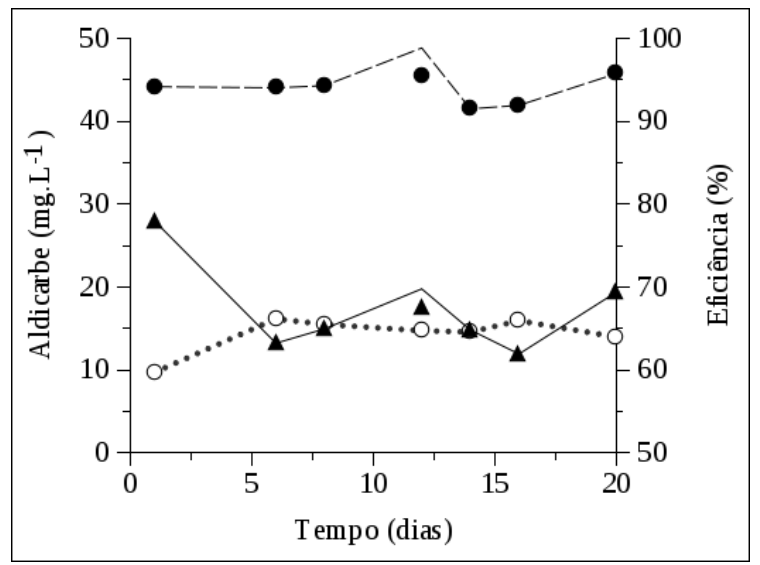

(e)

Figura 5.20. Variação da concentração de aldicarbe, concentração de aldicarbe total e eficiência de remoção no Ensaio 5 (a), 10 (b), 20 (c), 30 (d) e 40 (e) sob condições sulfetogênicas.

[Notação: •, aldicarbe afluente; ০, aldicarbe efluente; ---, aldicarbe total afluente; $\cdots \cdot \cdot \cdot$, aldicarbe total efluente; ム , eficiência de remoção de aldicarbe; — - eficiência de remoção de aldicarbe total.] 
Nas amostras do afluente, o sulfóxido de aldicarbe foi detectado em pequenas concentrações (correspondente a 7,6\%, em média). Entretanto, nas amostras do efluente nenhum dos metabólitos principais foi encontrado. O RAHLF operando sob condições sulfetogênicas atingiu eficiências de remoção de aldicarbe elevadas para 5, 10 e 20 mg.L ${ }^{-1}$, com ligeira queda à medida que a concentração afluente sofreu aumento (90,5; 83,2 e 80,7\%, respectivamente). Com o aumento da concentração de 30 e $40 \mathrm{mg} \cdot \mathrm{L}^{-1}$, houve redução da eficiência de remoção para 70,5 e 65,3\%, respectivamente. Percebe-se claramente o estabelecimento de dois patamares de eficiência de remoção, um de 5 a 20 mg. $\mathrm{L}^{-1}$ e outro de 30 a $40 \mathrm{mg} \cdot \mathrm{L}^{-1}$.

As maiores conversões de sulfato ocorreram nas concentrações de 5 e 10 mg. $\mathrm{L}^{-1}$ de aldicarbe, com valor médio de 49,5 e 67,7\%, respectivamente. O aumento da concentração de aldicarbe não causou somente queda na sua remoção, mas também redução da conversão de sulfato, atingindo valores médios de 36,2; 38,3 e 30,6\% para as concentrações de 20, 30 e $40 \mathrm{mg} . \mathrm{L}^{-1}$, respectivamente. Essa observação é um indicativo de que o sulfato foi utilizado concomitantemente ao aldicarbe, ou seja, que fez parte do processo de degradação. Entretanto, pelas eficiências de conversão de sulfato reduzidas e eficiências de remoção de aldicarbe elevadas, a quantidade de sulfato adicionada ao afluente foi provavelmente maior do que a necessária para ocorrência do processo.

O pH não variou significativamente em nenhuma das condições avaliadas indicando que a alcalinidade do sistema manteve-o tamponado. Os valores próximos da relação AI/AP também foram uma evidência de que o sistema permaneceu relativamente estável em todos ensaios.

As concentrações de metano e gás carbônico se mantiveram aproximadamente estáveis mesmo com o aumento da concentração, indicando que, concomitantemente à sulfetogênese, coexistiram organismos metanogênicos. Assim, foi confirmado que o processo sulfetogênico estava estabelecido visto que não houve variação, em termos médios, da composição do biogás. A composição do biogás permaneceu próxima a $80 \%$ de metano e $20 \%$ de gás carbônico em todas as concentrações avaliadas. Na análise do biogás não foi realizada a determinação de gás sulfídrico, o que poderia alterar os valores da composição do biogás.

A presença de metano no biogás foi um indicativo da coexistência de arquéias metanogênicas e bactérias redutoras de sulfato (BRS) no reator sulfetogênico. É estabelecido que, em baixas relações de $\mathrm{DQO} / \mathrm{SO}_{4}{ }^{2-}$, a maior parte da DQO pode ser degradada via redução de sulfato (van HOUTEN, 1996). Como a quantidade de sulfato adicionada ao meio foi determinada de uma relação empírica e de correlações indiretas, certamente a relação 
aldicarbe/sulfato utilizada foi menor do que o necessário, ou seja, a relação $\mathrm{DQO} / \mathrm{SO}_{4}{ }^{2-}$ pode ser maior para processos de biorremediação de aldicarbe por via sulfetogênica.

Embora exista um número limitado de bactérias redutoras de sulfato (BRS) capazes de crescer em ambientes fermentativos de açúcares e aminoácidos, é mais provável que, em ecossistemas naturais e em digestores anaeróbios, as BRS participem das últimas etapas no processo de mineralização do que da etapa fermentativa inicial (POSTGATE, 1984). Kazumi e Capone (1986) observaram a formação e posterior consumo de metilamina (supostamente um metabólito da degradação de aldicarbe) na ausência de oxigênio pelas BRS na presença de um inibidor da metanogênese. Assim, as BRS e as arquéias metanogênicas podem competir pela metilamina. Embora em sistemas de tratamento de efluentes líquidos a competição entre os dois organismos seja um fator preponderante na operação, no processo de biorremediação de aldicarbe isto não representa um problema, já que as concentrações de metano e sulfeto são muito baixas.

A constante cinética aparente de primeira ordem $\left(\mathrm{k}_{1 \mathrm{ap}}\right)$ foi ligeiramente maior com $\mathrm{o}$ aumento da concentração de 5 para $10 \mathrm{mg} \cdot \mathrm{L}^{-1}$ com valores de 0,232 e 0,278 $\mathrm{h}^{-1}$, respectivamente. Entretanto o aumento da concentração reduziu em 50\% o valor, formando um patamar nas concentrações de 20 e $30 \mathrm{mg} \cdot \mathrm{L}^{-1}$ (0,126 e 0,103 $\mathrm{h}^{-1}$, respectivamente). O aumento da concentração para $40 \mathrm{mg} . \mathrm{L}^{-1}$ reduziu significativamente o valor de $\mathrm{k}_{\text {lap }}$, atingindo $0,065 \mathrm{~h}^{-1}$ (Tabela 5.10). Percebe-se que, para as maiores concentrações, principalmente em 30 e $40 \mathrm{mg} . \mathrm{L}^{-1}$, a curva tende a um comportamento típico de cinética de ordem zero. Os perfis de sulfato/sulfeto também seguiram tendência semelhante. Essa variação pode indicar um processo de inibição, com aumento da constante até um ponto máximo e decrescendo a seguir. 


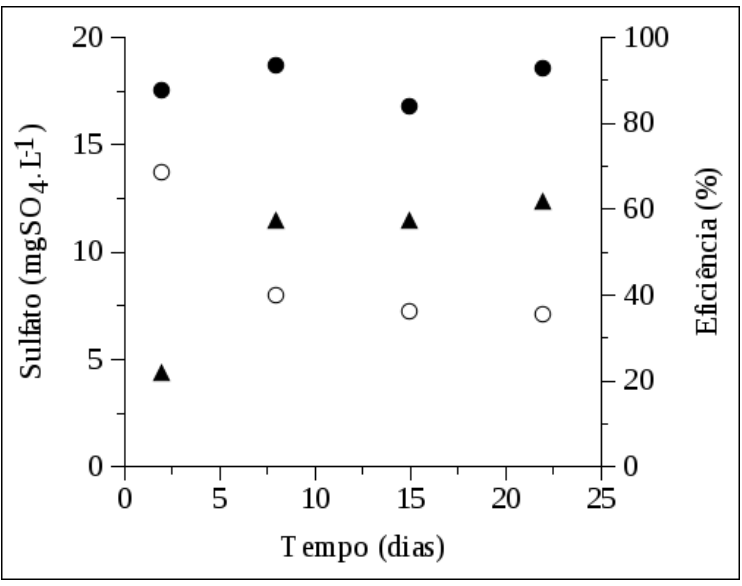

(a)

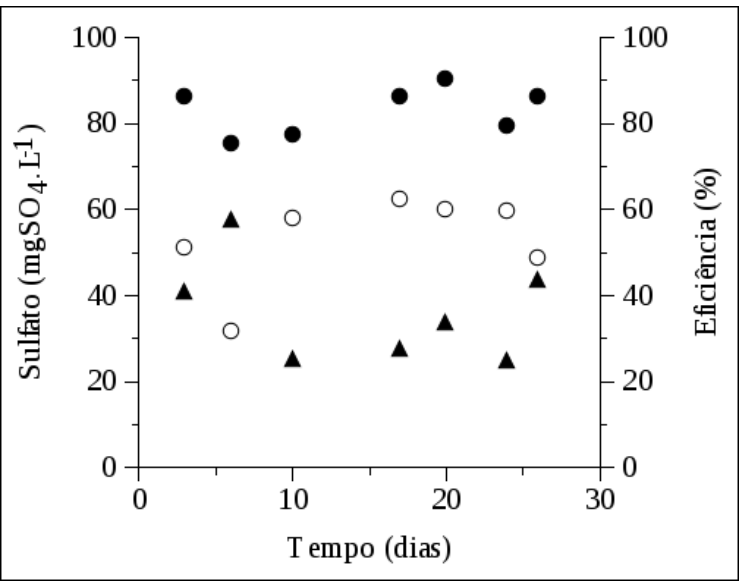

(c)

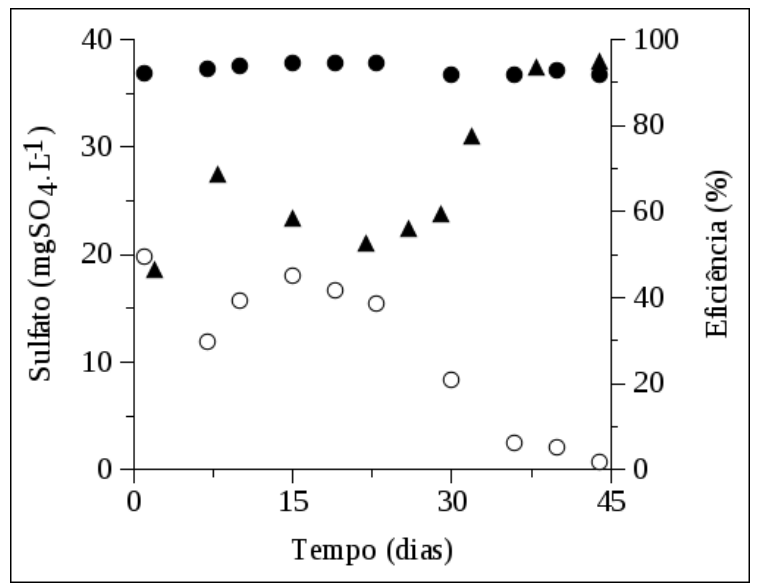

(b)

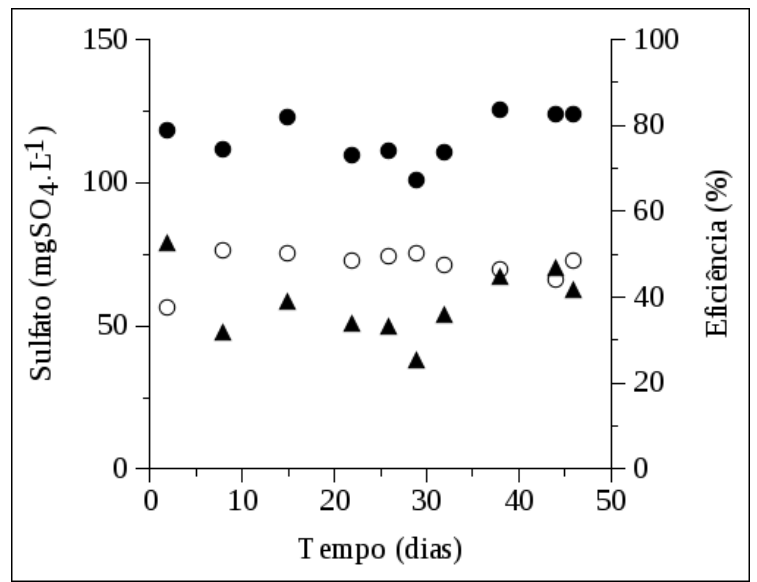

(d)

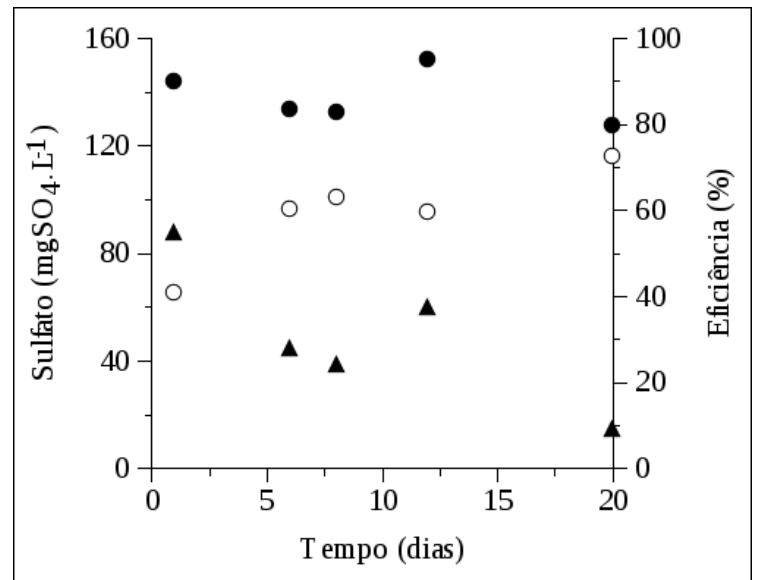

(e)

Figura 5.21. Variação da concentração de sulfato e eficiência de conversão no Ensaio 5 (a), 10 (b), 20 (c), 30 (d) e 40 (e) sob condições sulfetogênicas.

[Notação: •, sulfato afluente; ○, sulfato efluente; $\boldsymbol{\Lambda}$, eficiência de conversão de sulfato.] 


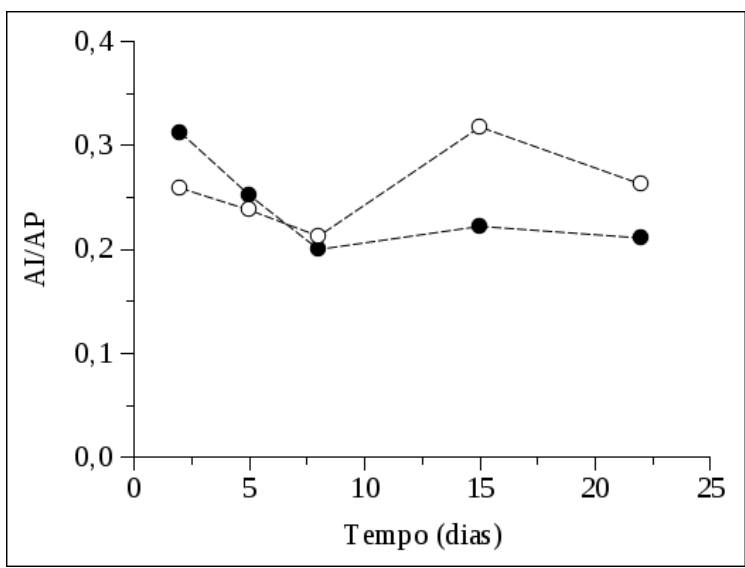

(a)

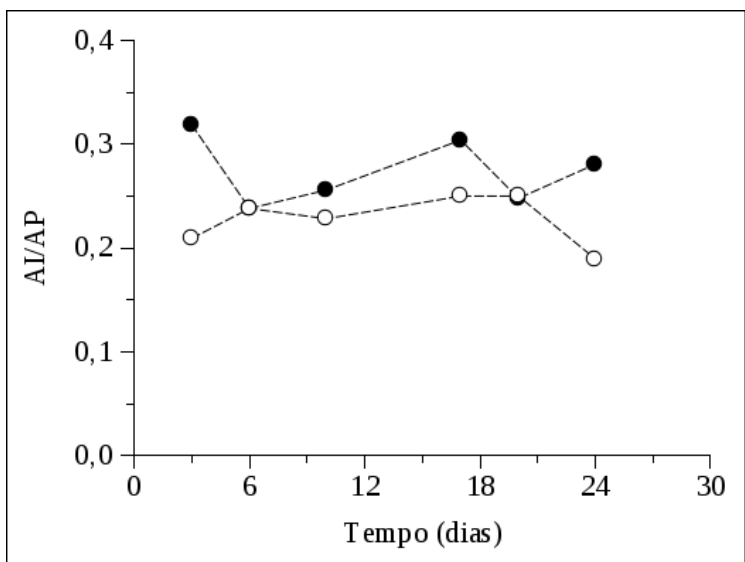

(c)

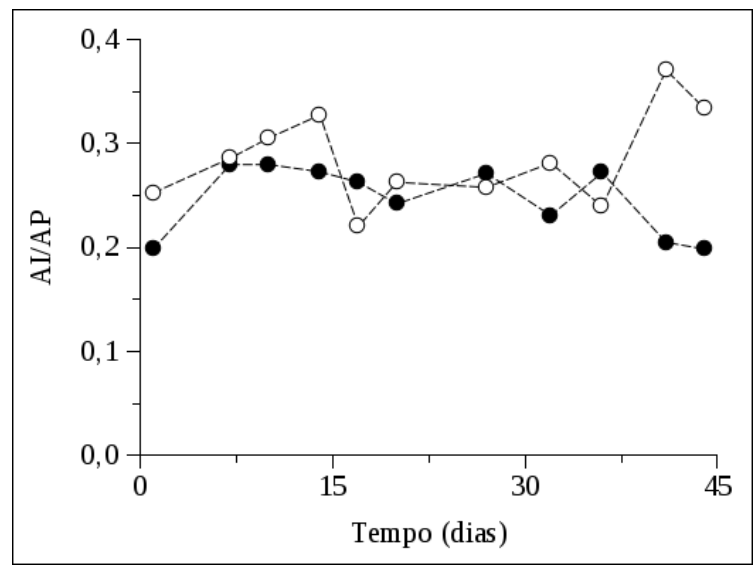

(b)

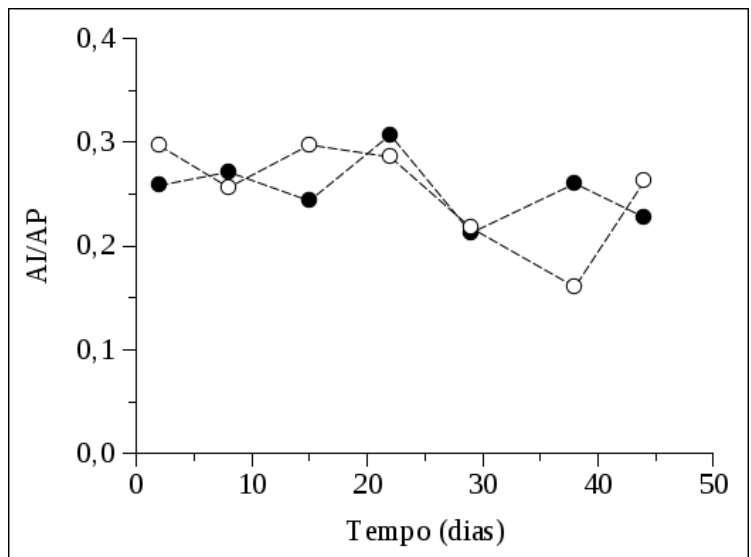

(d)

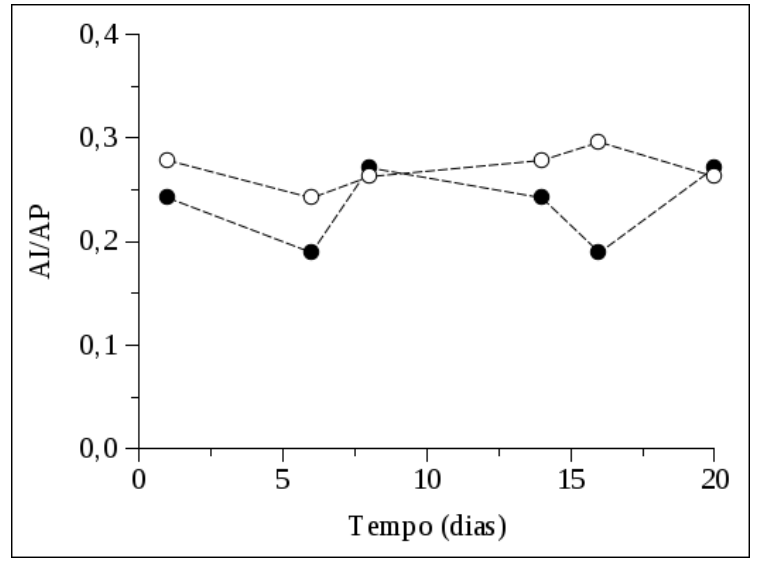

(e)

Figura 5.22. Variação da relação AI/AP no Ensaio 5 (a), 10 (b), 20 (c), 30 (d) e 40 (e) sob condições sulfetogênicas.

[Notação: •, afluente; o, efluente.] 


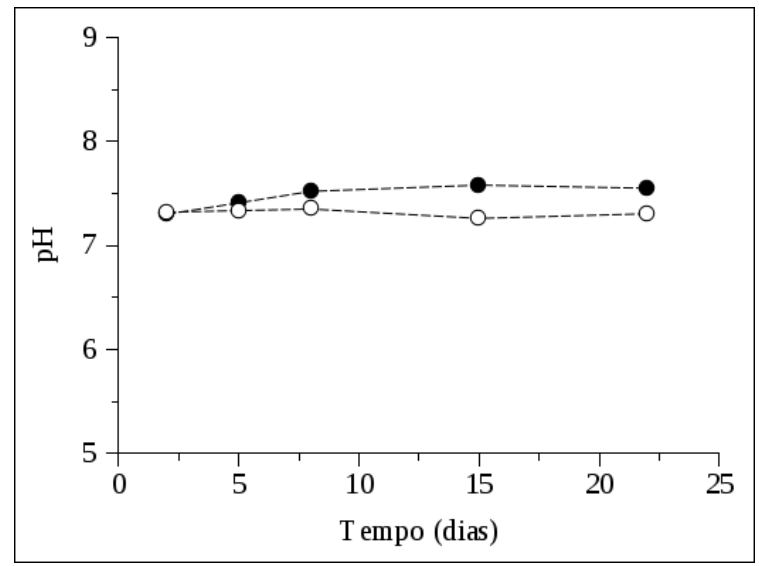

(a)

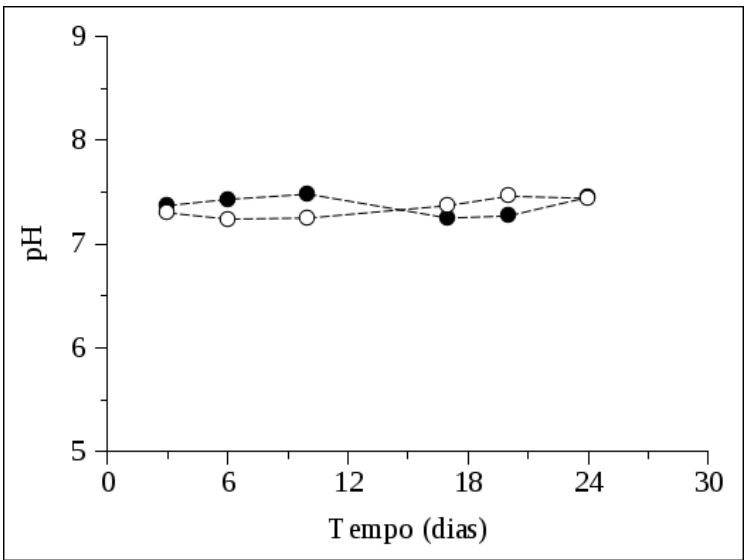

(c)

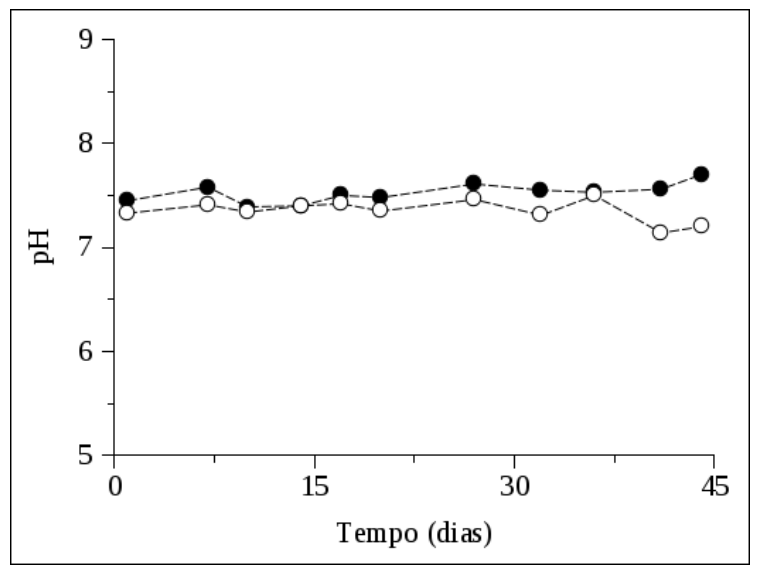

(b)

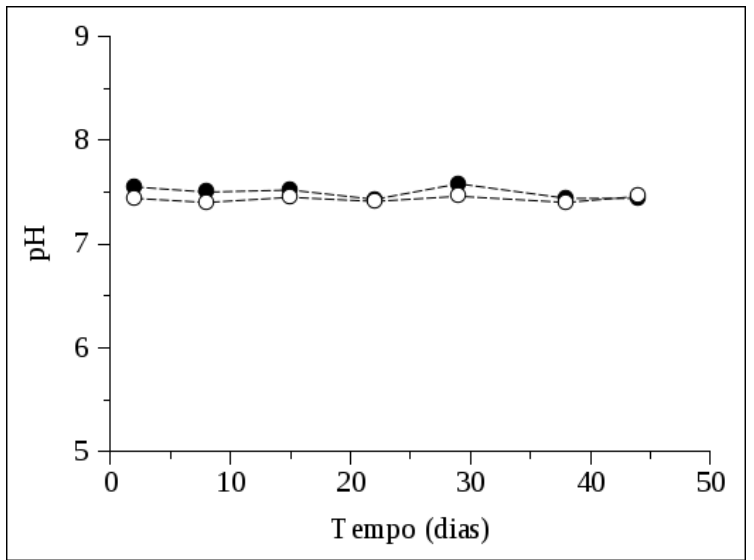

(d)

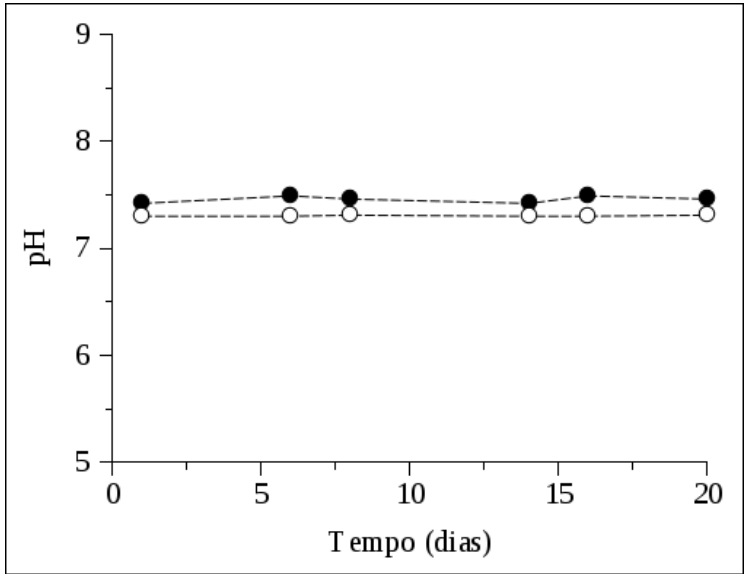

(e)

Figura 5.23. Variação do pH no Ensaio 5 (a), 10 (b), 20 (c), 30 (d) e 40 (e) sob condições sulfetogênicas.

[Notação: •, afluente; ○, efluente.] 


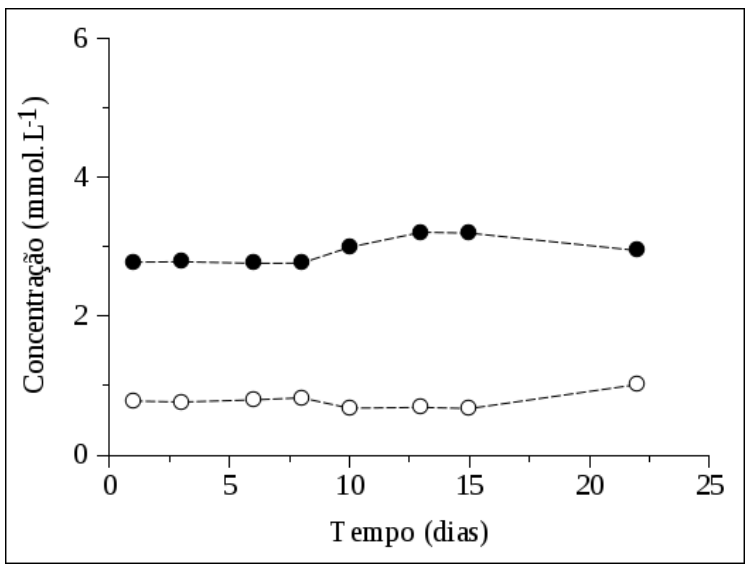

(a)

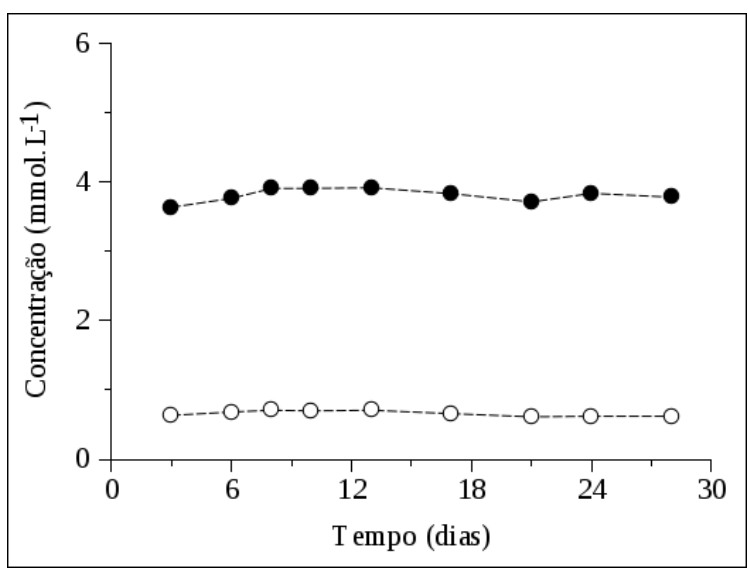

(c)

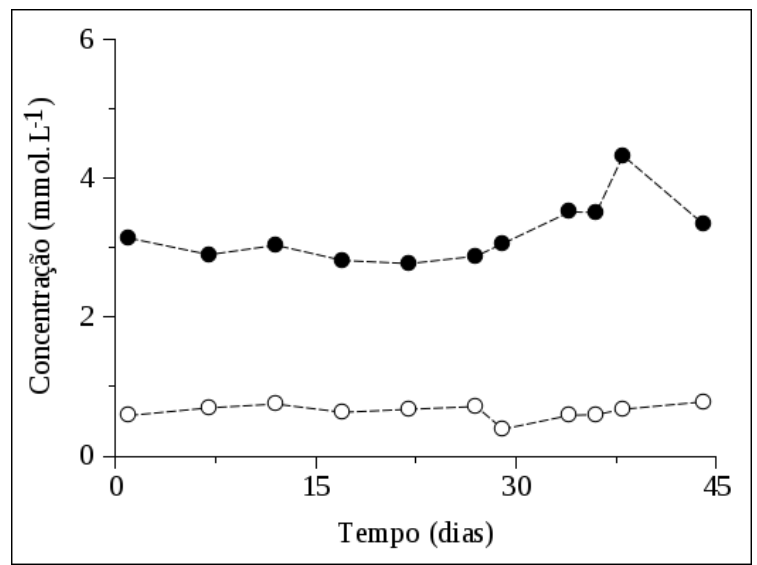

(b)

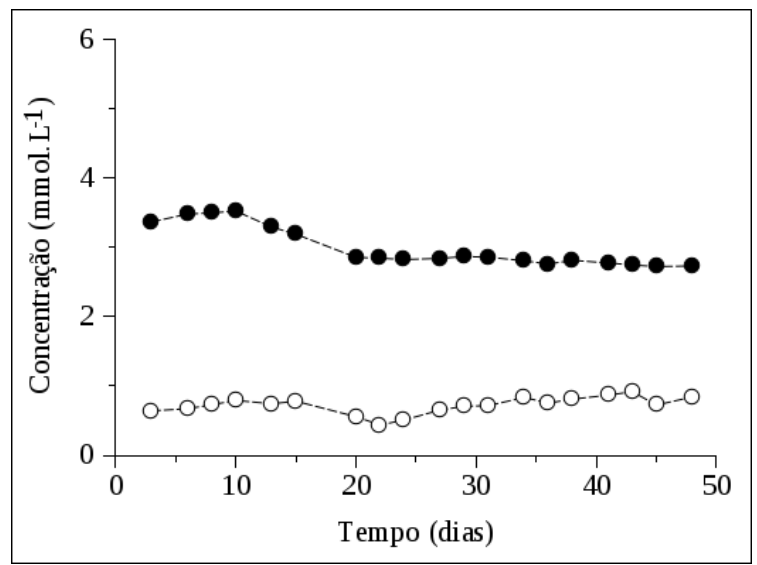

(d)

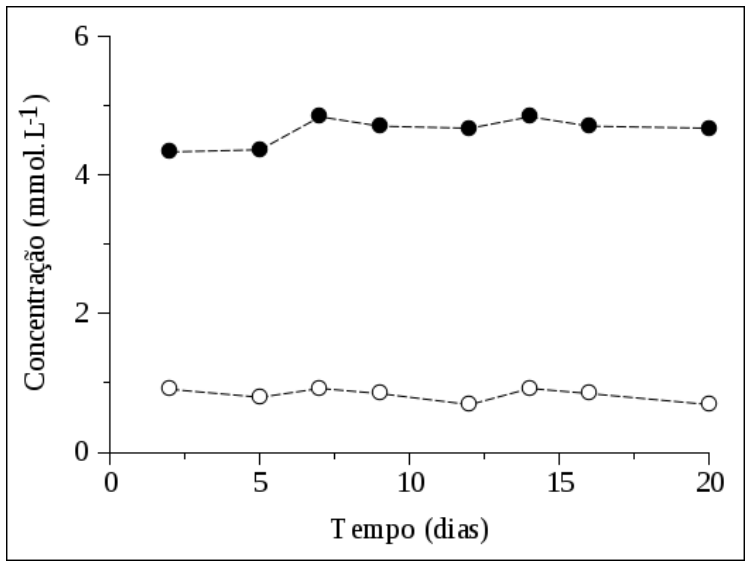

(e)

Figura 5.24. Variação da concentração de metano e gás carbônico no biogás no Ensaio 5 (a), 10 (b), 20 (c), 30 (d) e 40 (e) sob condições sulfetogênicas.

[Notação: •, metano; ○, gás carbônico.] 


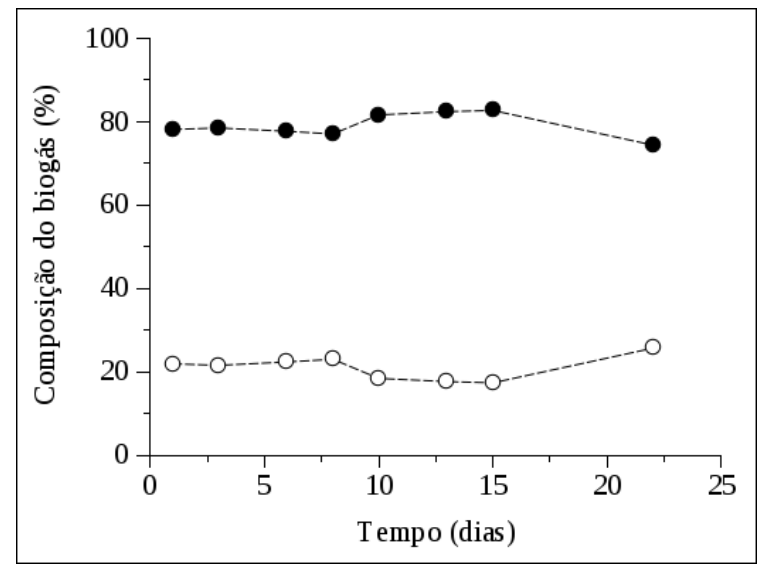

(a)

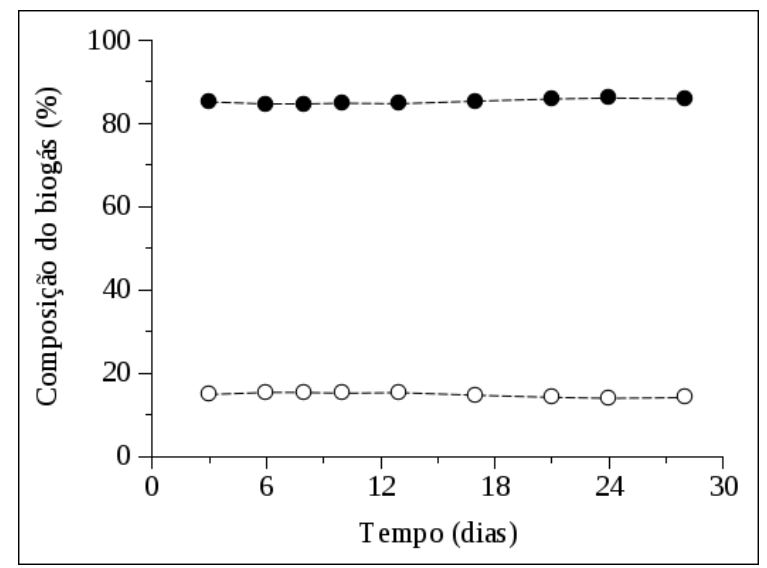

(c)

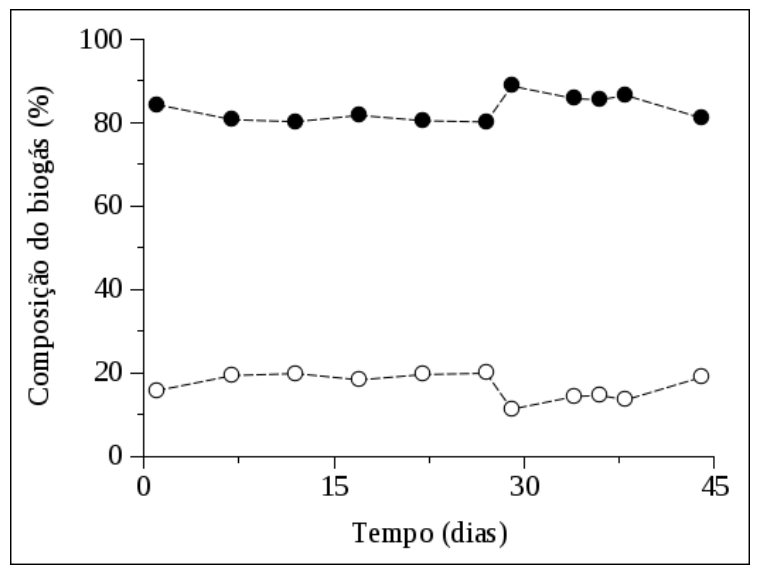

(b)

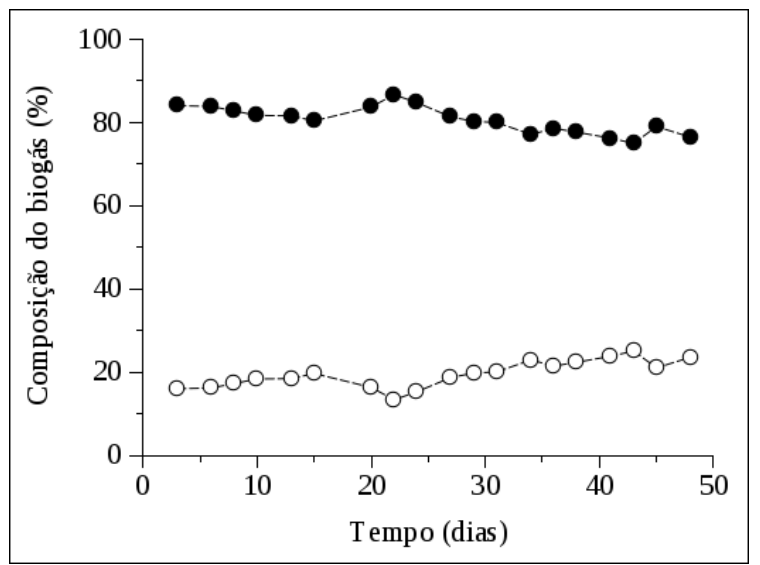

(d)

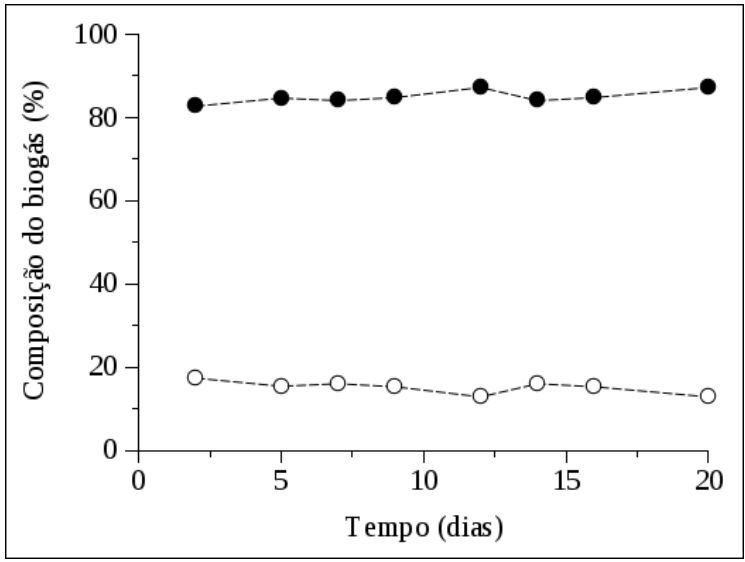

(e)

Figura 5.25. Variação da composição do biogás no Ensaio 5 (a), 10 (b), 20 (c), 30 (d) e 40 (e) sob condições sulfetogênicas.

[Notação: •, metano; o, gás carbônico.] 
Tabela 5.9 - Valores médios da concentração de aldicarbe, seus metabólitos e aldicarbe total e eficiências de remoção para diferentes condições avaliadas no reator sulfetogênico.

\begin{tabular}{|c|c|c|c|c|c|c|}
\hline & \multirow{2}{*}{ Variável } & \multicolumn{5}{|c|}{ Ensaio* } \\
\hline & & 5 & 10 & 20 & 30 & 40 \\
\hline \multirow{4}{*}{ 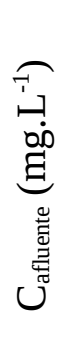 } & Aldicarbe & $5,0 \pm 0,6^{(7)}$ & $10,4 \pm 0,9^{(7)}$ & $21,4 \pm 1,6^{(7)}$ & $31,0 \pm 2,2^{(11)}$ & $43,9 \pm 1,6^{(7)}$ \\
\hline & Sulfóxido de aldicarbe & $0,0 \pm 0,0^{(7)}$ & $0,8 \pm 0,6^{(7)}$ & $0,6 \pm 1,2^{(7)}$ & $1,2 \pm 0,9^{(11)}$ & $0,5 \pm 1,3^{(7)}$ \\
\hline & Sulfona de aldicarbe & $0,0 \pm 0,0^{(7)}$ & $0,0 \pm 0,0^{(7)}$ & $0,0 \pm 0,0^{(7)}$ & $0,0 \pm 0,0^{(11)}$ & $0,0 \pm 0,0^{(7)}$ \\
\hline & Aldicarbe total & $5,0 \pm 0,6^{(7)}$ & $11,3 \pm 1,0^{(7)}$ & $21,9 \pm 1,7^{(7)}$ & $32,5 \pm 2,8^{(11)}$ & $44,3 \pm 2,5^{(7)}$ \\
\hline \multirow{4}{*}{ 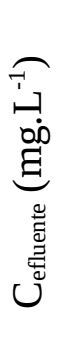 } & Aldicarbe & $0,5 \pm 0,2^{(6)}$ & $1,7 \pm 0,5^{(7)}$ & $4,2 \pm 1,1^{(3)}$ & $9,2 \pm 2,3^{(10)}$ & $15,2 \pm 0,9^{(6)}$ \\
\hline & Sulfóxido de aldicarbe & $0,0 \pm 0,0^{(6)}$ & $0,0 \pm 0,0^{(7)}$ & $0,2 \pm 0,3^{(3)}$ & $0,0 \pm 0,0^{(10)}$ & $0,0 \pm 0,0^{(6)}$ \\
\hline & Sulfona de aldicarbe & $0,0 \pm 0,0^{(6)}$ & $0,0 \pm 0,0^{(7)}$ & $0,0 \pm 0,0^{(3)}$ & $0,0 \pm 0,0^{(10)}$ & $0,0 \pm 0,0^{(6)}$ \\
\hline & Aldicarbe total & $0,5 \pm 0,2^{(6)}$ & $1,7 \pm 0,5^{(7)}$ & $4,4 \pm 1,1^{(3)}$ & $9,2 \pm 2,3^{(10)}$ & $15,2 \pm 0,9^{(6)}$ \\
\hline \multirow{2}{*}{ 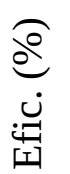 } & Aldicarbe & $90,5 \pm 5,1^{(6)}$ & $83,2 \pm 4,4^{(7)}$ & $80,7 \pm 5,6^{(3)}$ & $70,5 \pm 6,1^{(10)}$ & $65,3 \pm 2,7^{(6)}$ \\
\hline & Aldicarbe total & $90,5 \pm 5,1^{(6)}$ & $84,4 \pm 4,4^{(7)}$ & $79,9 \pm 5,9^{(3)}$ & $72,0 \pm 5,8^{(10)}$ & $65,7 \pm 3,2^{(6)}$ \\
\hline
\end{tabular}

* Os números entre parênteses indicam o número de amostras utilizadas para composição da média. 


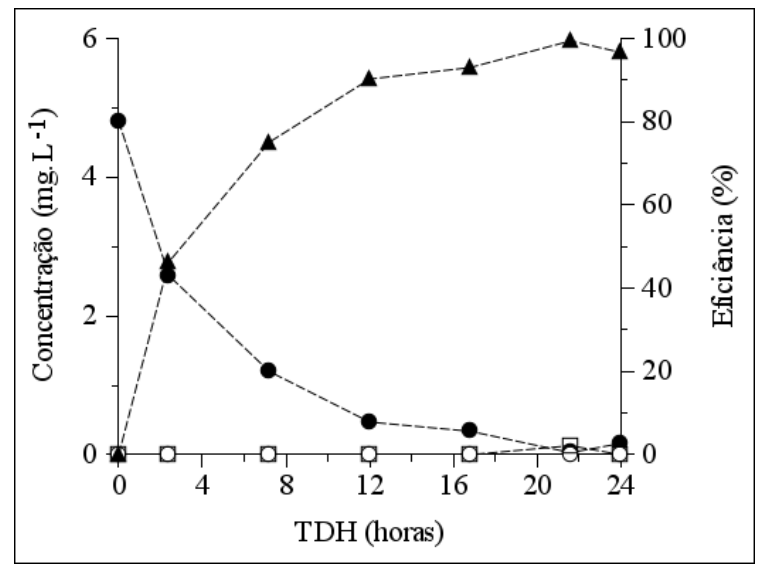

(a)

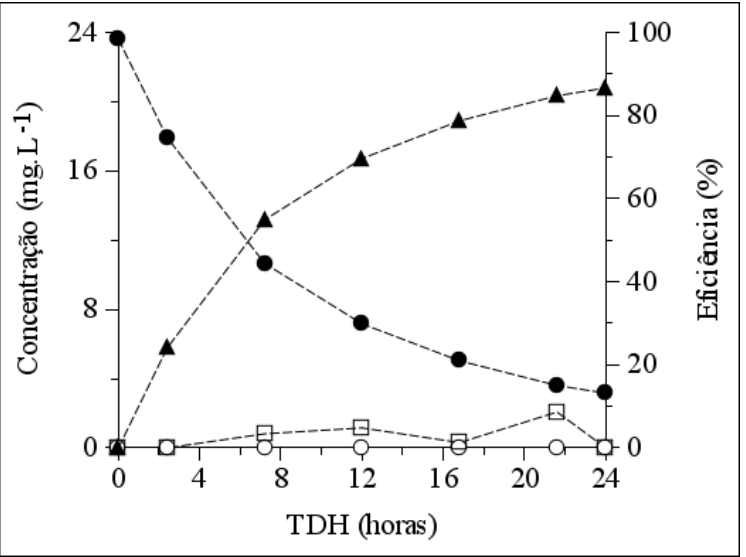

(c)

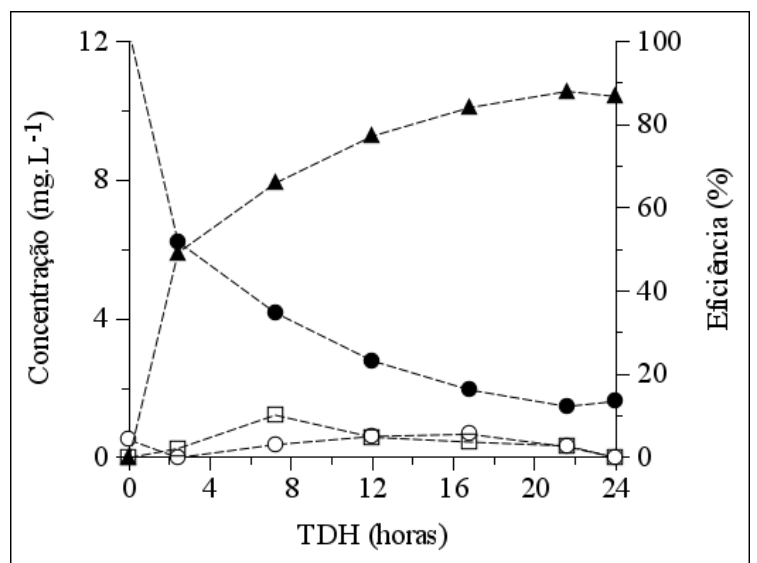

(b)

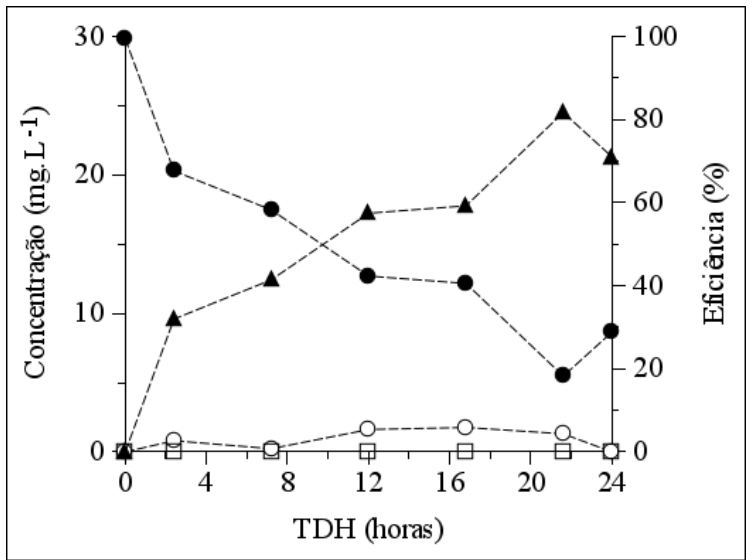

(d)

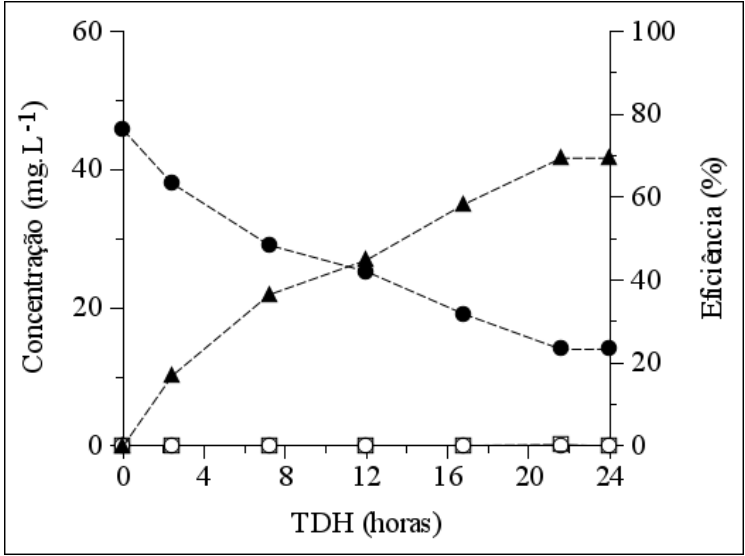

(e)

Figura 5.26. Perfis temporais ao longo do RAHLF da concentração de aldicarbe, sulfóxido de aldicarbe e sulfona de aldicarbe e eficiência de remoção de aldicarbe no Ensaio 5 (a), 10 (b), 20 (c), 30 (d) e 40 (e) sob condições sulfetogênicas.

[Notação: - --, aldicarbe; -०-, sulfóxido de aldicarbe; $-\square-$, sulfona de aldicarbe;

- $\boldsymbol{\Delta}$-, eficiência de remoção de aldicarbe.] 


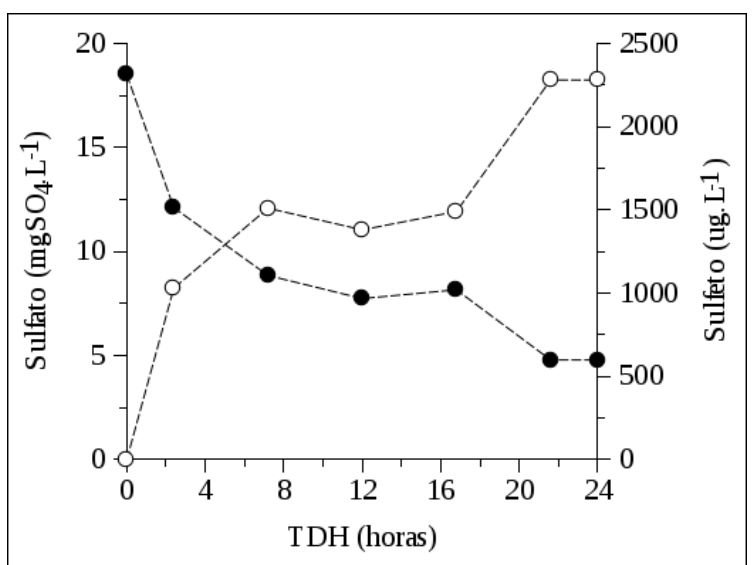

(a)

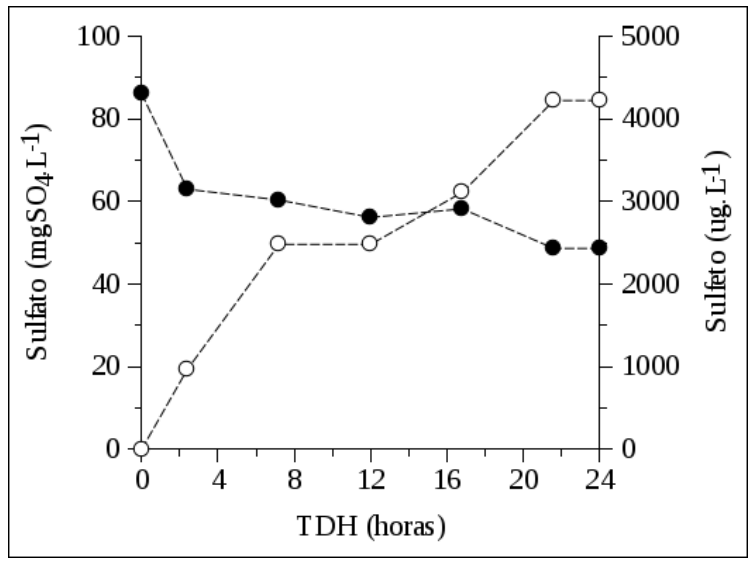

(c)

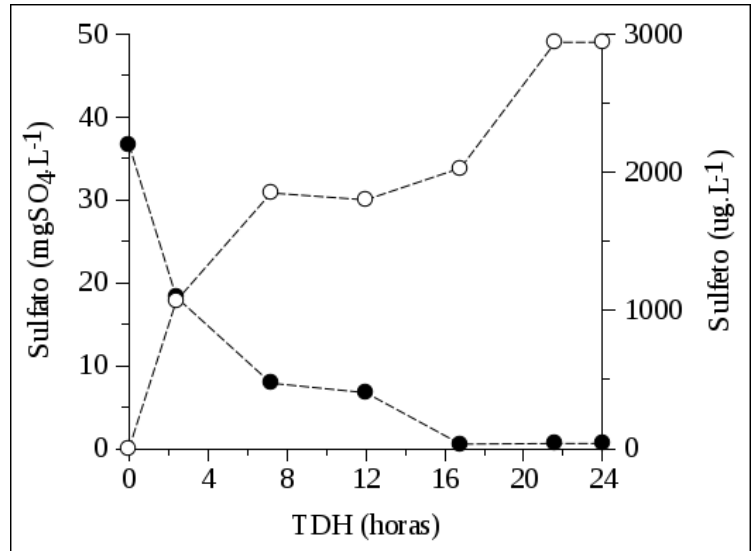

(b)

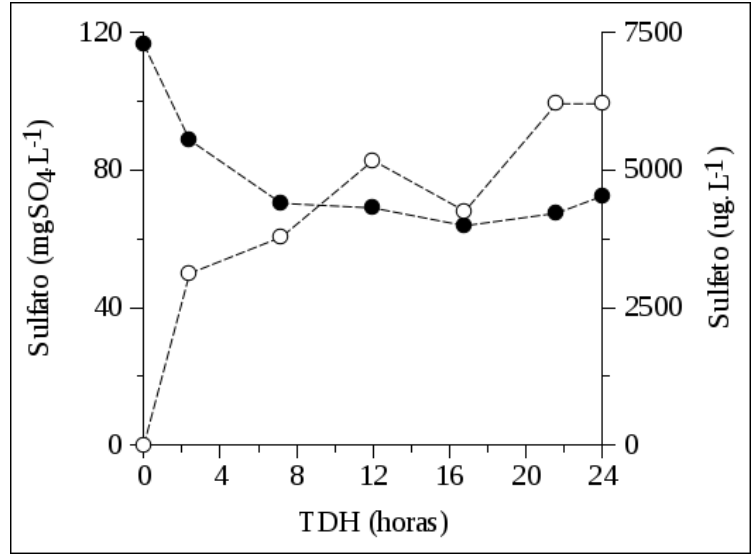

(d)

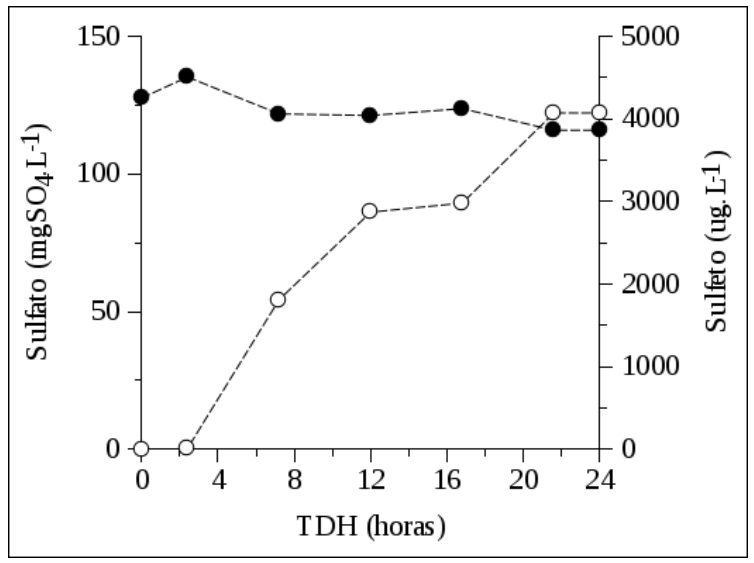

(e)

Figura 5.27. Perfis temporais ao longo do RAHLF da concentração de sulfato e sulfeto no

Ensaio 5 (a), 10 (b), 20 (c), 30 (d) e 40 (e) sob condições sulfetogênicas.

[Notação: -•-, sulfato; - --, sulfeto.] 
Tabela 5.10. Parâmetros cinéticos aparentes determinados para diferentes concentrações de aldicarbe sob condições sulfetogênicas.

\begin{tabular}{ccccc}
\hline $\mathrm{C}_{\text {aldicarbe }}\left(\mathrm{mg} \cdot \mathrm{L}^{-1}\right)$ & $\begin{array}{c}\mathrm{k}_{1 \text { ap }} \\
\left(\mathrm{h}^{-1}\right)\end{array}$ & $\begin{array}{c}\mathrm{S}_{0} \\
\left(\mathrm{mg}_{\text {aldicarbe }} \mathrm{L}^{-1}\right)\end{array}$ & $\begin{array}{c}\mathrm{S}_{\min } \\
\left(\mathrm{mg}_{\text {aldicarbe. }} \mathrm{L}^{-1}\right)\end{array}$ & $\mathrm{r}^{2}$ \\
\hline 5 & $0,232 \pm 0,025$ & $4,7 \pm 0,2$ & $0,2 \pm 0,1$ & 0,994 \\
10 & $0,278 \pm 0,060$ & $11,9 \pm 0,7$ & $1,9 \pm 0,4$ & 0,976 \\
20 & $0,126 \pm 0,004$ & $23,5 \pm 0,2$ & $2,3 \pm 0,2$ & 0,999 \\
30 & $0,103 \pm 0,052$ & $28,1 \pm 2,3$ & $6,0 \pm 4,0$ & 0,932 \\
40 & $0,065 \pm 0,016$ & $44,8 \pm 1,2$ & $5,4 \pm 4,9$ & 0,992 \\
\hline
\end{tabular}

\subsubsection{Reator desnitrificante}

Nas Figuras 5.28 a 5.33 é apresentada variação da concentração de aldicarbe e metabólitos, nitrato e nitrito, relação AI/AP, pH e concentração e composição percentual dos componentes do biogás, respectivamente. Na Tabela 5.11 são mostrados os valores médios da concentração de aldicarbe e metabólitos para as diferentes concentrações avaliadas. As Figuras 5.34 e 5.35 trazem os perfis temporais de aldicarbe e metabólitos e nitrato/nitrito ao longo do RAHLF. Na Tabela 5.12 encontram-se os parâmetros cinéticos aparentes determinados após ajuste da equação proposta aos dados experimentais.

Para as concentrações afluentes de 5 e 10 mg.L $\mathrm{L}^{-1}$, operando em condições desnitrificantes, observou-se no RAHLF elevadas eficiências de remoção de aldicarbe, com valores médios de 88 e 94,3\%, respectivamente. Entretanto, o aumento da concentração afluente para 20 e 30 mg. $\mathrm{L}^{-1}$ causou redução brusca na eficiência de remoção para 32,3 e 40,2\%, respectivamente (Figura 5.28). Em função dos resultados insatisfatórios, o ensaio com a concentração de $40 \mathrm{mg} . \mathrm{L}^{-1}$ não foi realizado.

Embora a eficiência de conversão de aldicarbe tenha se reduzido com o tempo, a conversão de nitrato foi elevada (89, 80, 85 e 96\% para as concentrações de 5, 10, 20 e 30 mg. $L^{-1}$, respectivamente), indicando que outra fonte de carbono pode ter sido utilizada para efetivar o processo de desnitrificação. As duas hipóteses possíveis seriam o uso de carbono proveniente da endogenia da biomassa ou de outros compostos presentes no produto comercial $\left(\right.$ Temik $^{\circledR}$ ), principalmente nas concentrações mais altas, como foi observado por Asgari, Sharif e Özden (1995). Outra observação importante foi a mudança gradual de coloração na biomassa, de uma coloração negra para coloração marrom, diferentemente dos 
outros sistemas que mantiveram cor negra em todos os ensaios.

O pH do sistema permaneceu estável em todas concentrações avaliadas, evidenciadas pela pequena variação nas relações de AI/AP, mesmo nas concentrações mais críticas, de 20 e $30 \mathrm{mg} \cdot \mathrm{L}^{-1}$.

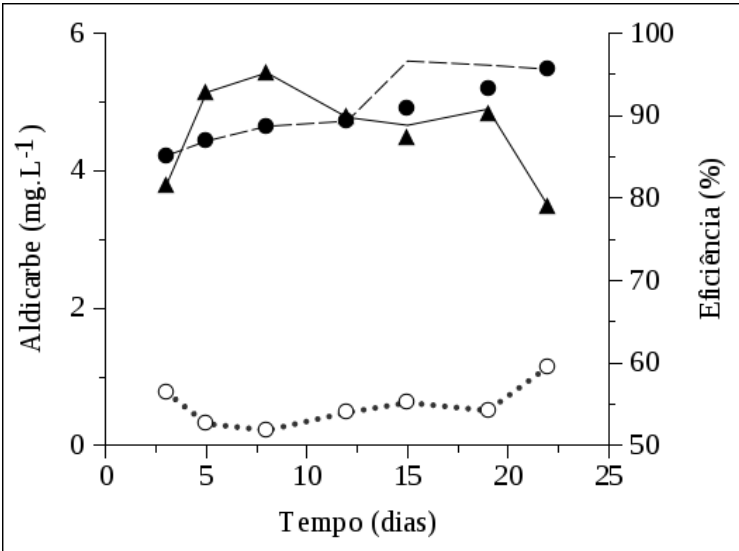

(a)

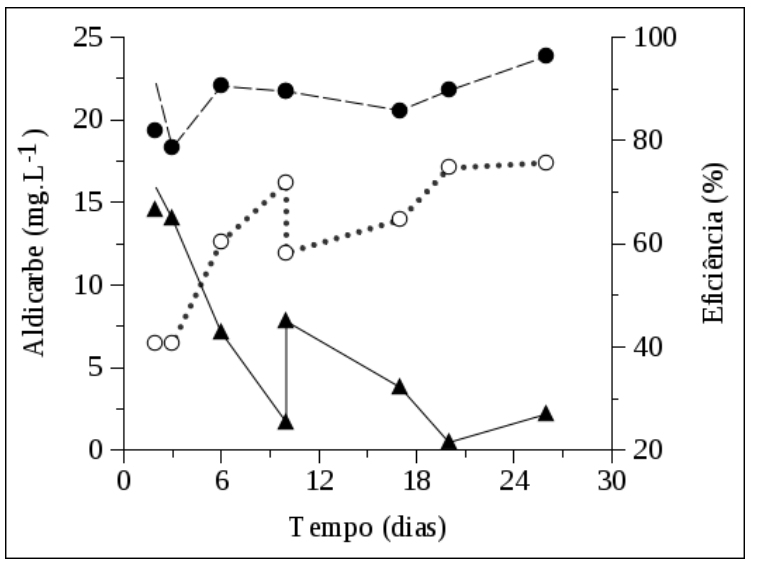

(c)

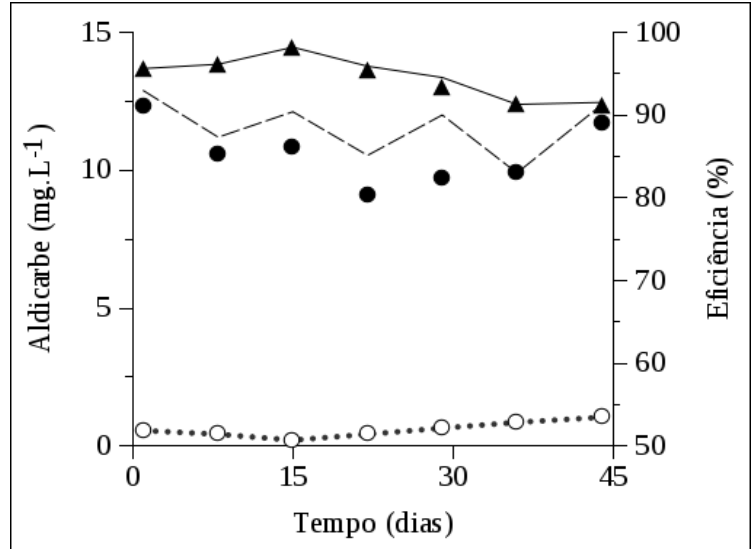

(b)

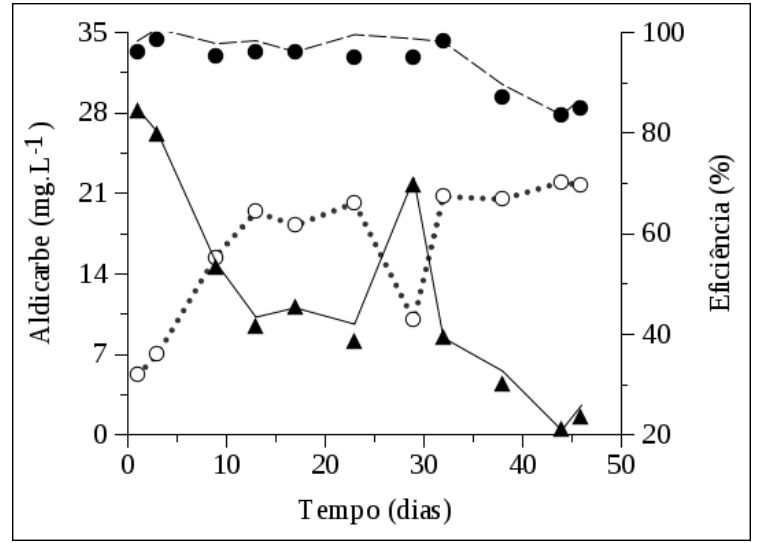

(d)

Figura 5.28. Variação da concentração de aldicarbe, concentração de aldicarbe total e eficiência de remoção no Ensaio 5 (a), 10 (b), 20 (c) e 30 (d) sob condições desnitrificantes. [Notação: •, aldicarbe afluente; ○, aldicarbe efluente; ---, aldicarbe total afluente; …..., aldicarbe total efluente; ム , eficiência de remoção de aldicarbe; — - eficiência de remoção de aldicarbe total.] 
A determinação de metano no sistema revelou a presença de organismos metanogênicos no material suporte, mesmo com nitrato no meio. Entretanto, as concentrações foram muito baixas, inferiores a $5 \mathrm{mmol} . \mathrm{L}^{-1}$, indicando que, mesmo presente, não era o processo predominante.

Para a determinação das constantes cinéticas aparentes, o modelo cinético de ordem zero foi o que melhor representou os dados experimentais. Entretanto, para as concentrações de 20 e 30 mg. $\mathrm{L}^{-1}$, em função dos resultados insatisfatórios, os mesmos não foram determinados. A partir do pressuposto pelo modelo de degradação de Monod de que, em altas concentrações, a cinética do sistema reacional tem comportamento de ordem zero, uma hipótese para explicar o melhor ajuste é a de que o sistema já estaria operando em condições próximas à concentração máxima.

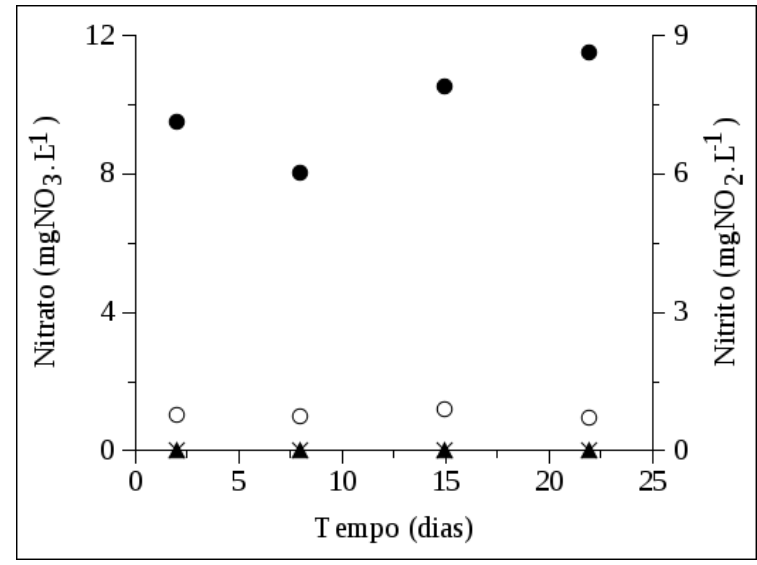

(a)

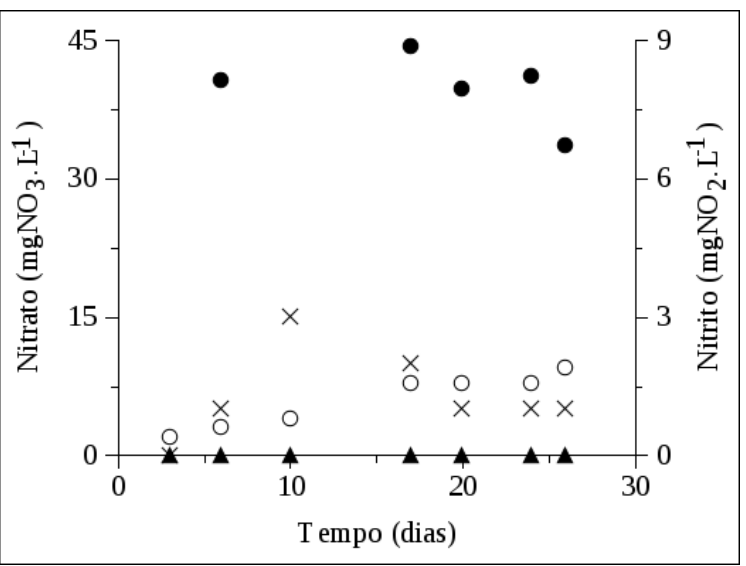

(c)

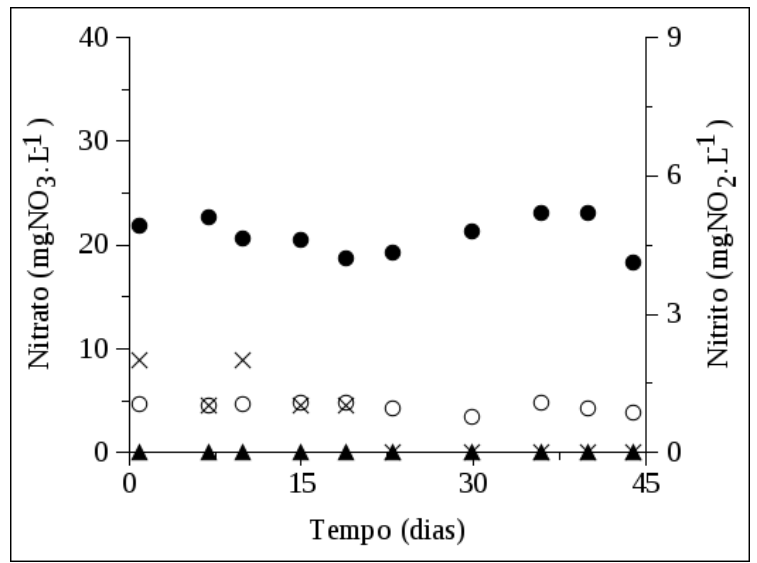

(b)

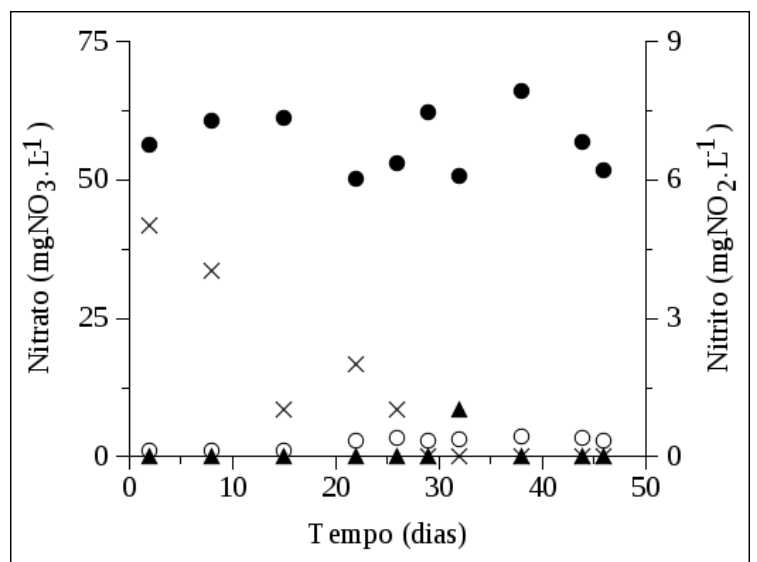

(d)

Figura 5.29. Variação da concentração de nitrato e nitrito no Ensaio 5 (a), 10 (b), 20 (c) e 30 (d) sob condições desnitrificantes.

[Notação: •, nitrato afluente; ○, nitrato efluente; $\boldsymbol{\Delta}$, nitrito afluente; ×, nitrito efluente.] 


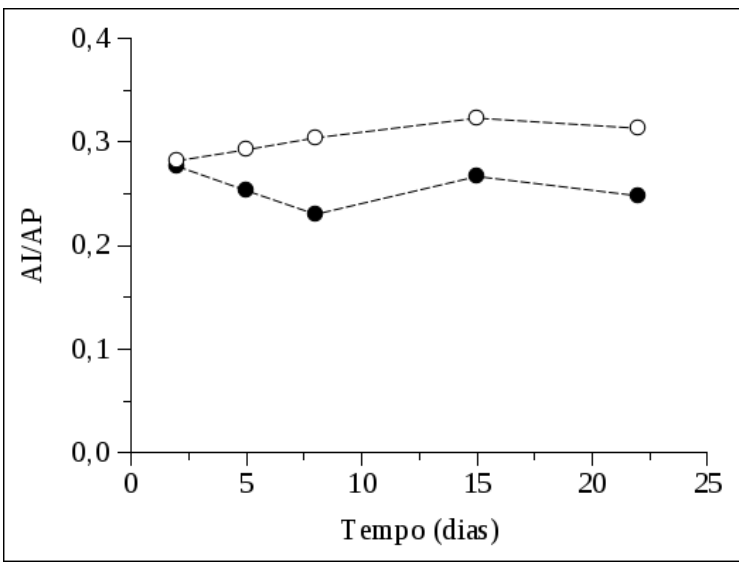

(a)

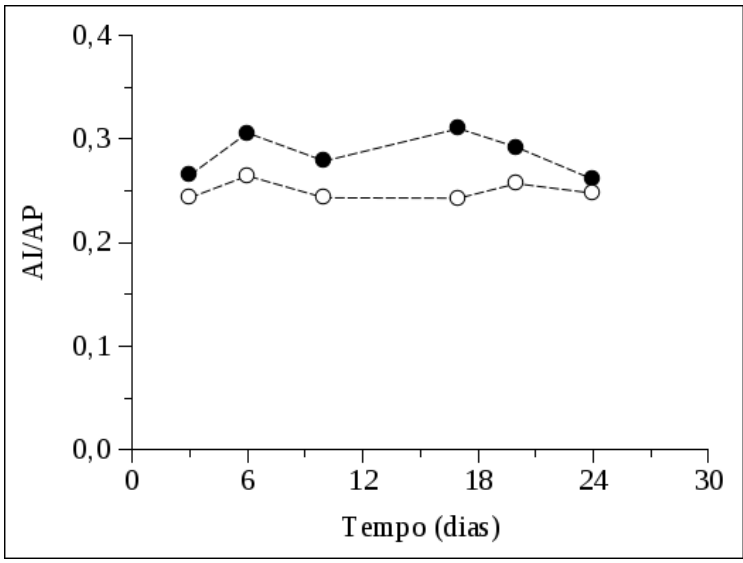

(c)

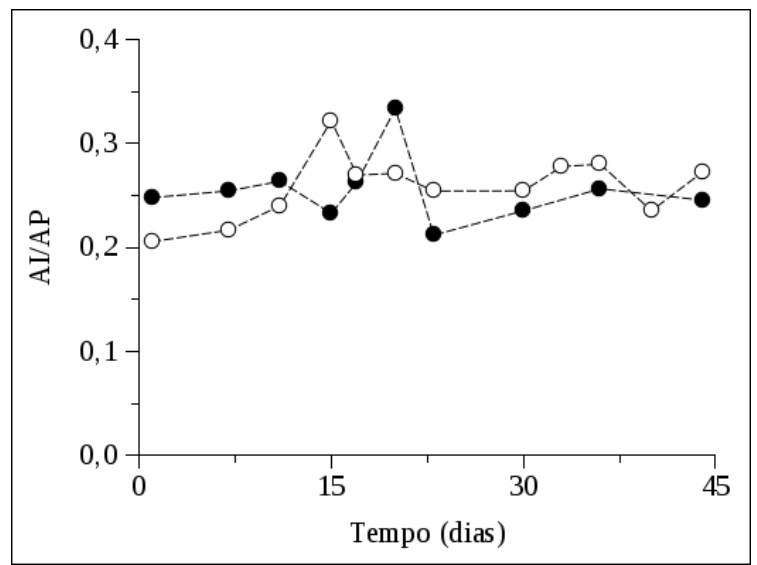

(b)

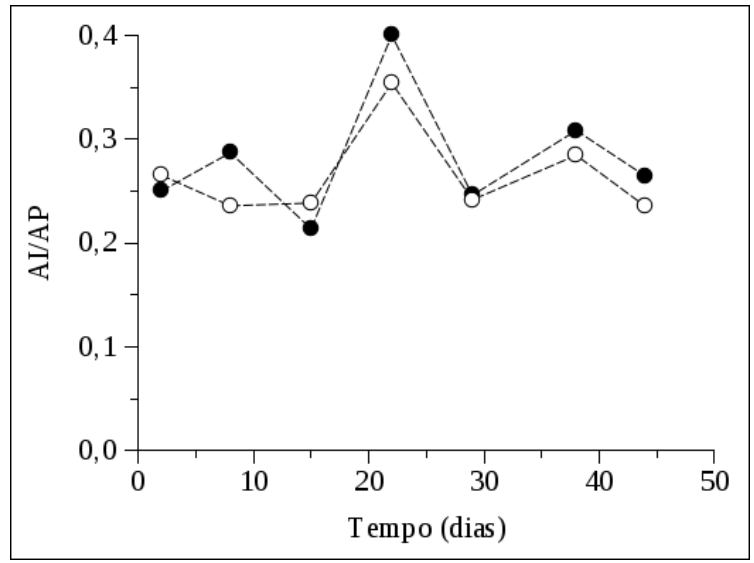

(d)

Figura 5.30. Variação da concentração de alcalinidade a bicarbonato no Ensaio 5 (a), 10 (b), 20 (c) e 30 (d) sob condições desnitrificantes.

[Notação: •, afluente; ○, efluente.] 


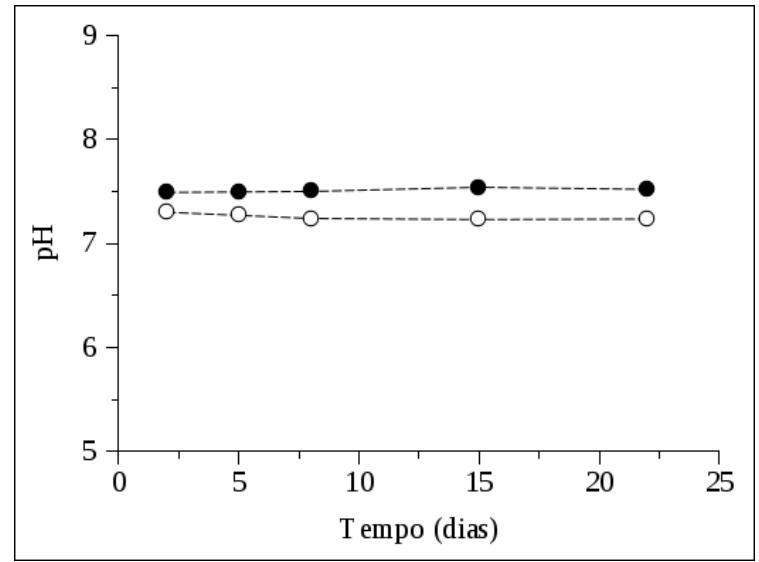

(a)

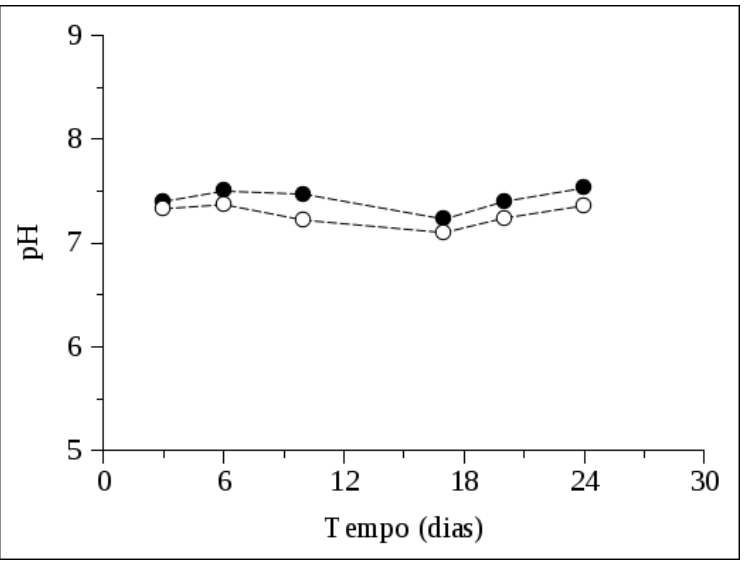

(c)

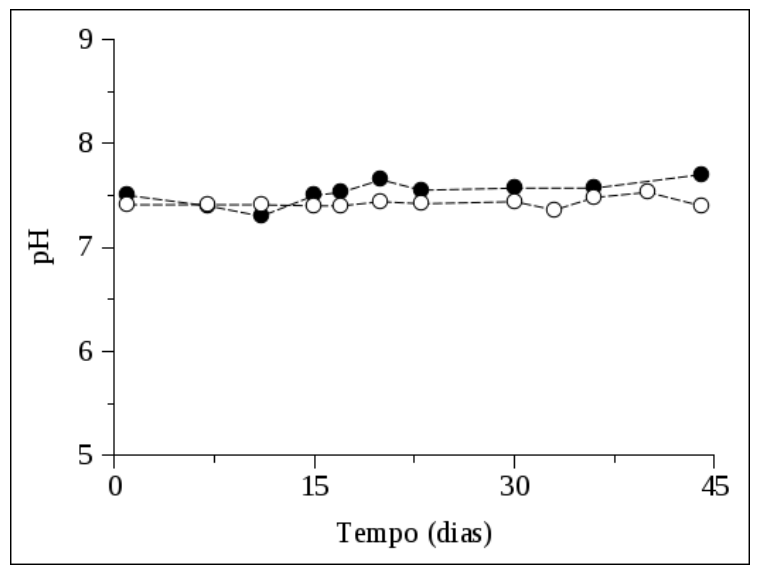

(b)

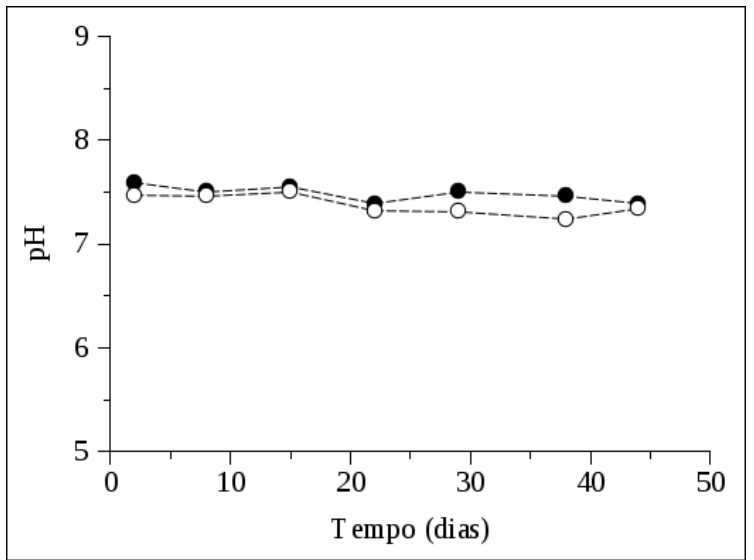

(d)

Figura 5.31. Variação do pH no Ensaio 5 (a), 10 (b), 20 (c) e 30 (d) sob condições desnitrificantes.

[Notação: •, afluente; ○, efluente.] 


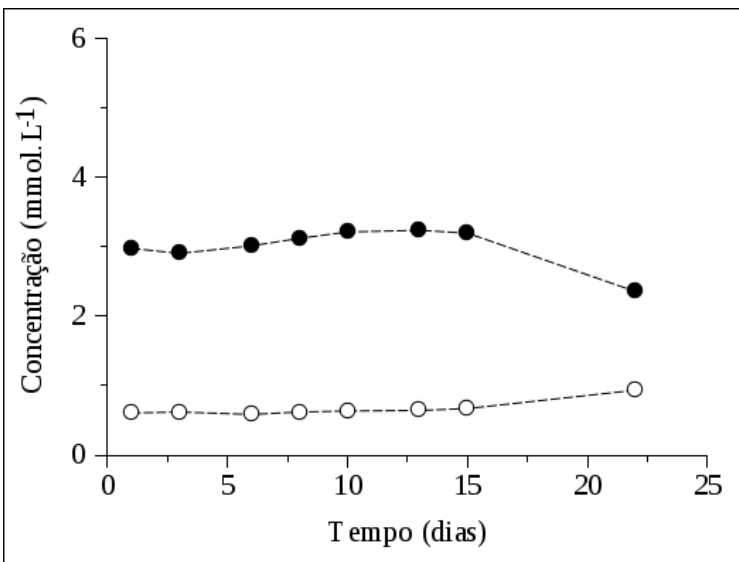

(a)

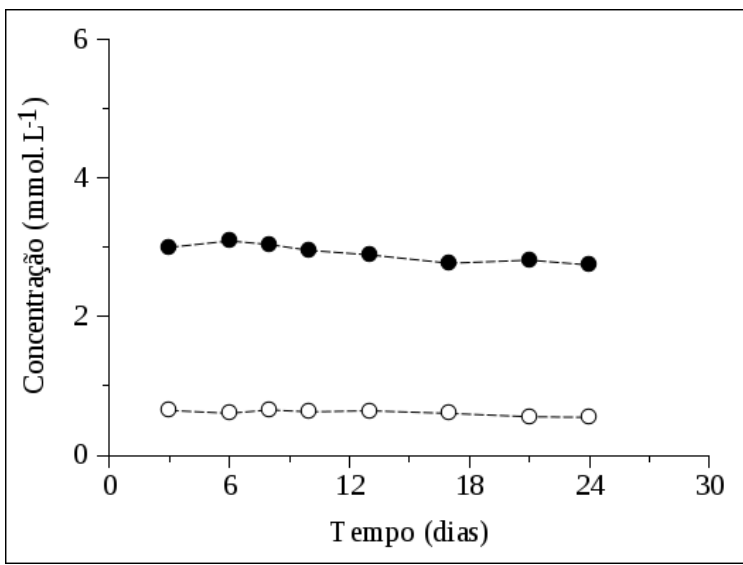

(c)

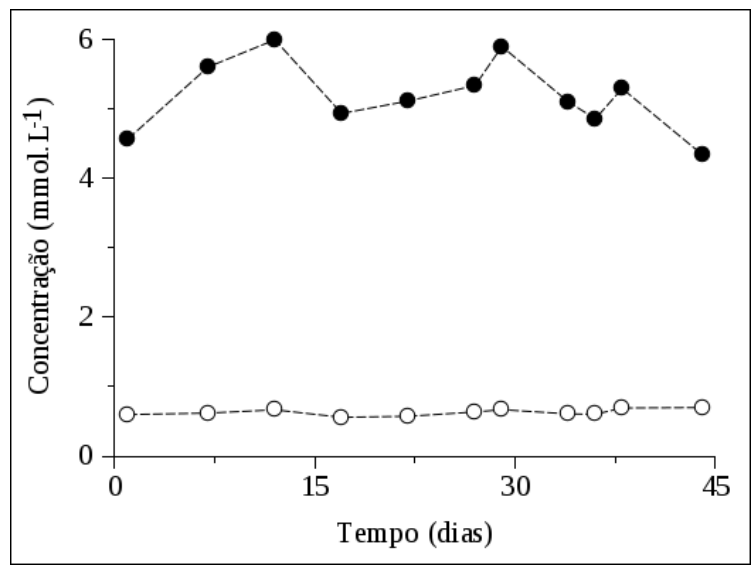

(b)

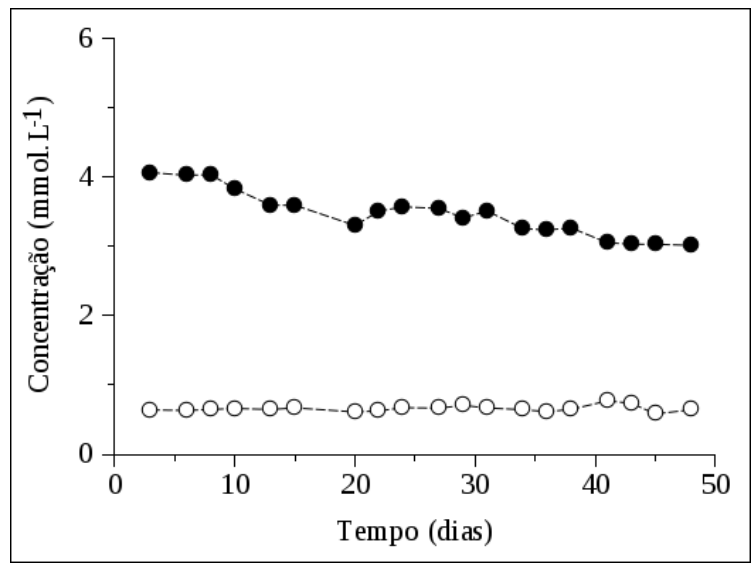

(d)

Figura 5.32. Variação da concentração de metano e gás carbônico no biogás no Ensaio 5 (a), 10 (b), 20 (c) e 30 (d) sob condições desnitrificantes.

[Notação: •, metano; ○, gás carbônico.] 


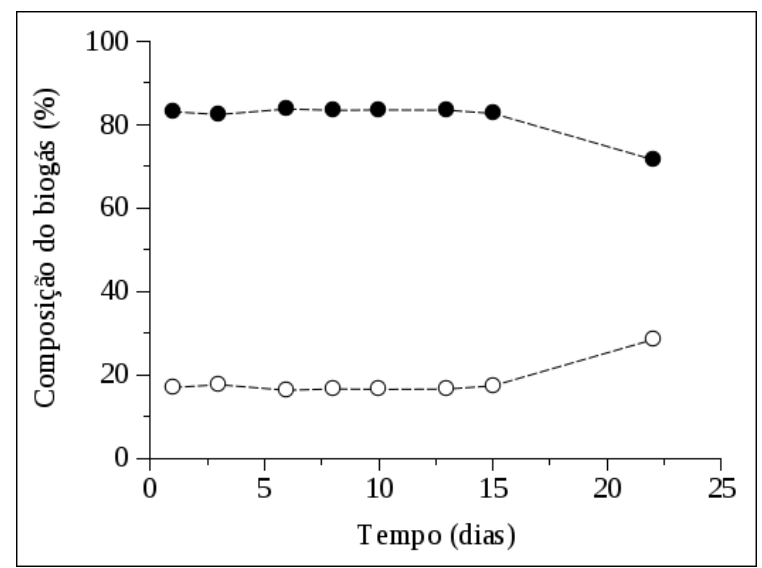

(a)

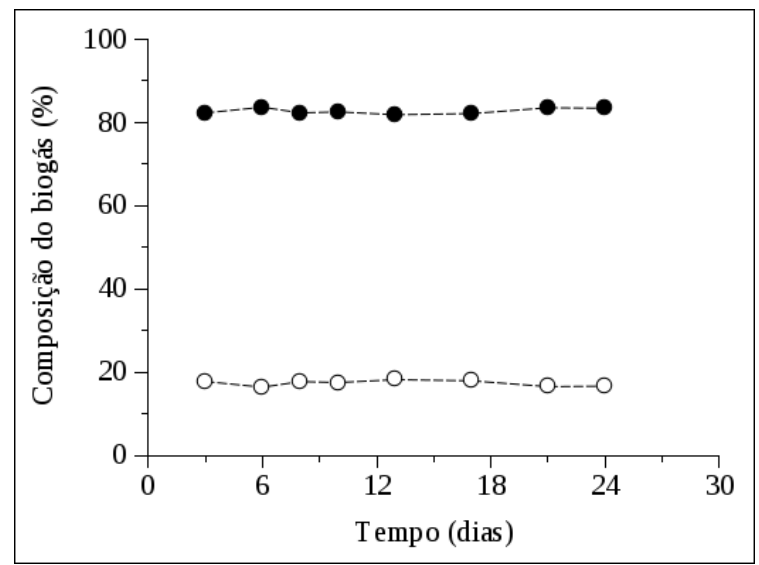

(c)

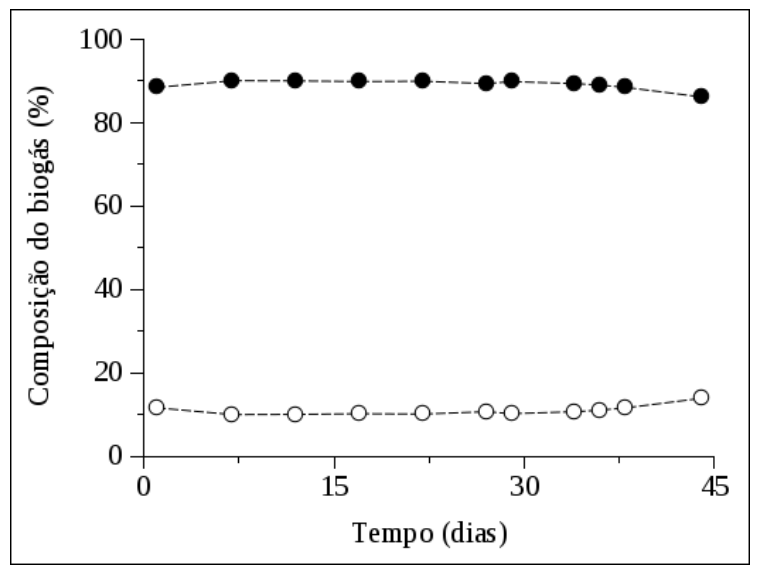

(b)

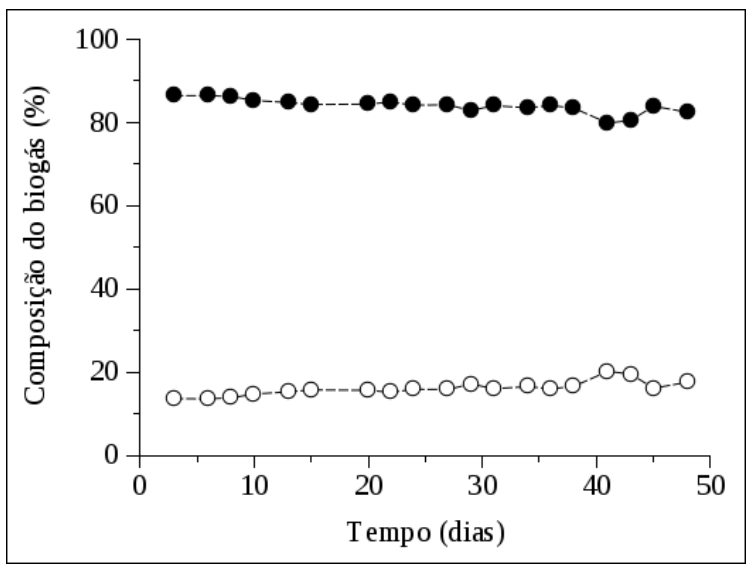

(d)

Figura 5.33. Variação da composição do biogás no Ensaio 5 (a), 10 (b), 20 (c) e 30 (d) sob condições desnitrificantes.

[Notação: •, metano; ○, gás carbônico.] 
Tabela 5.11 - Valores médios da concentração de aldicarbe, seus metabólitos e aldicarbe total e eficiências de remoção para diferentes condições avaliadas no reator desnitrificante.

\begin{tabular}{|c|c|c|c|c|c|}
\hline & \multirow{2}{*}{ Variável } & \multicolumn{4}{|c|}{ Ensaio* } \\
\hline & & 5 & 10 & 20 & 30 \\
\hline \multirow{4}{*}{ } & Aldicarbe & $4,8 \pm 0,4^{(7)}$ & $10,6 \pm 1,1^{(7)}$ & $21,2 \pm 1,7^{(8)}$ & $32,0 \pm 2,3^{(11)}$ \\
\hline & Sulfóxido de aldicarbe & $0,1 \pm 0,3^{(7)}$ & $0,9 \pm 0,5^{(7)}$ & $0,4 \pm 1,0^{(8)}$ & $0,9 \pm 0,7^{(11)}$ \\
\hline & Sulfona de aldicarbe & $0,0 \pm 0,0^{(7)}$ & $0,0 \pm 0,0^{(7)}$ & $0,0 \pm 0,0^{(8)}$ & $0,0 \pm 0,0^{(11)}$ \\
\hline & Aldicarbe total & $4,9 \pm 0,6^{(7)}$ & $11,6 \pm 1,1^{(7)}$ & $21,5 \pm 1,6^{(8)}$ & $32,9 \pm 2,5^{(11)}$ \\
\hline \multirow{4}{*}{ 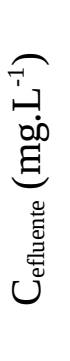 } & Aldicarbe & $0,6 \pm 0,3^{(7)}$ & $0,6 \pm 0,3^{(7)}$ & $14,9 \pm 2,3^{(6)}$ & $18,7 \pm 3,8^{(9)}$ \\
\hline & Sulfóxido de aldicarbe & $0,0 \pm 0,0^{(7)}$ & $0,0 \pm 0,0^{(7)}$ & $0,0 \pm 0,0^{(6)}$ & $0,0 \pm 0,0^{(9)}$ \\
\hline & Sulfona de aldicarbe & $0,0 \pm 0,0^{(7)}$ & $0,0 \pm 0,0^{(7)}$ & $0,0 \pm 0,0^{(6)}$ & $0,0 \pm 0,0^{(9)}$ \\
\hline & Aldicarbe total & $0,6 \pm 0,3^{(7)}$ & $0,6 \pm 0,3^{(7)}$ & $14,9 \pm 2,3^{(6)}$ & $18,7 \pm 3,8^{(9)}$ \\
\hline \multirow{2}{*}{ 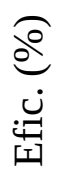 } & Aldicarbe & $88,0 \pm 5,9^{(7)}$ & $94,3 \pm 2,6^{(7)}$ & $32,3 \pm 9,6^{(6)}$ & $40,2 \pm 15,0^{(9)}$ \\
\hline & Aldicarbe total & $88,3 \pm 5,9^{(7)}$ & $94,7 \pm 2,5^{(7)}$ & $32,3 \pm 9,6^{(6)}$ & $41,7 \pm 15,0^{(9)}$ \\
\hline
\end{tabular}

* Os números entre parênteses indicam o número de amostras utilizadas para composição da média. 


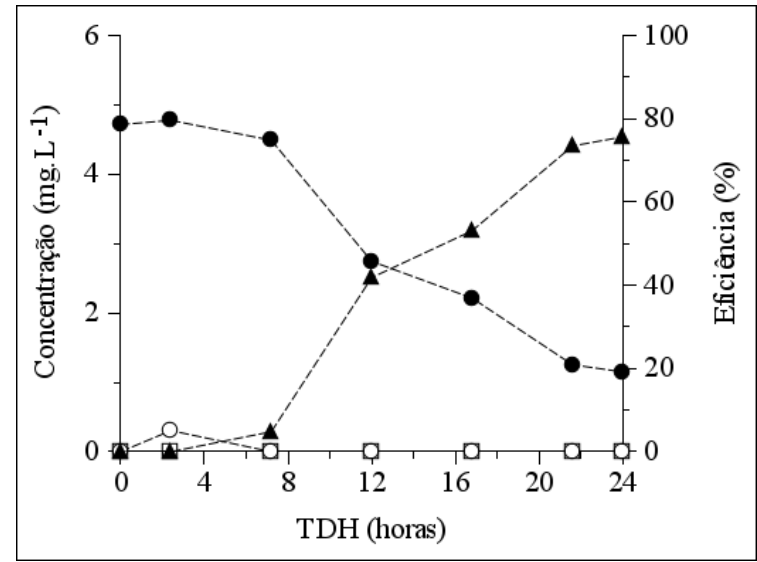

(a)

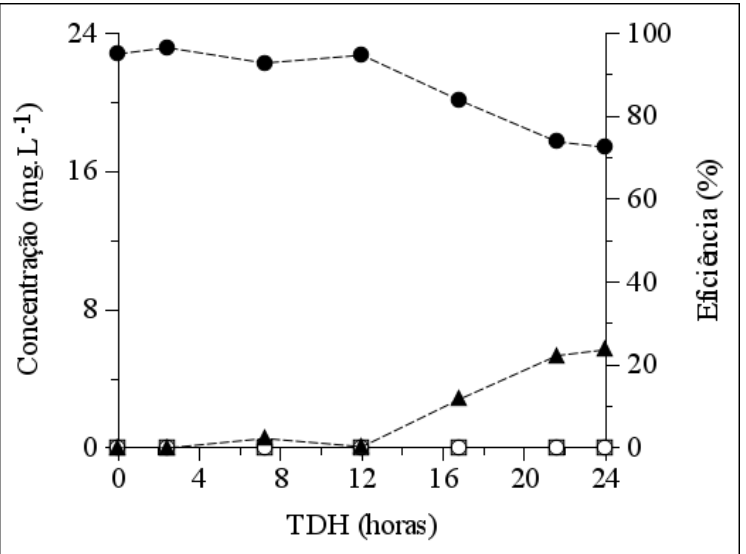

(c)

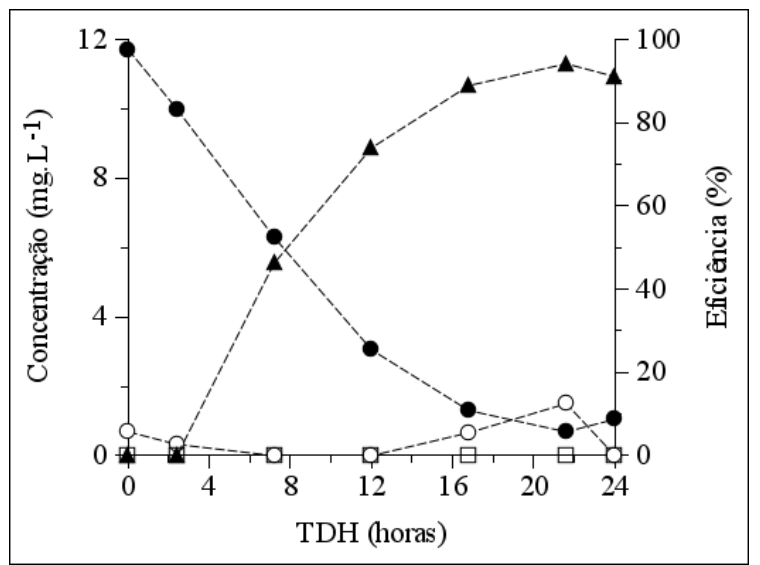

(b)

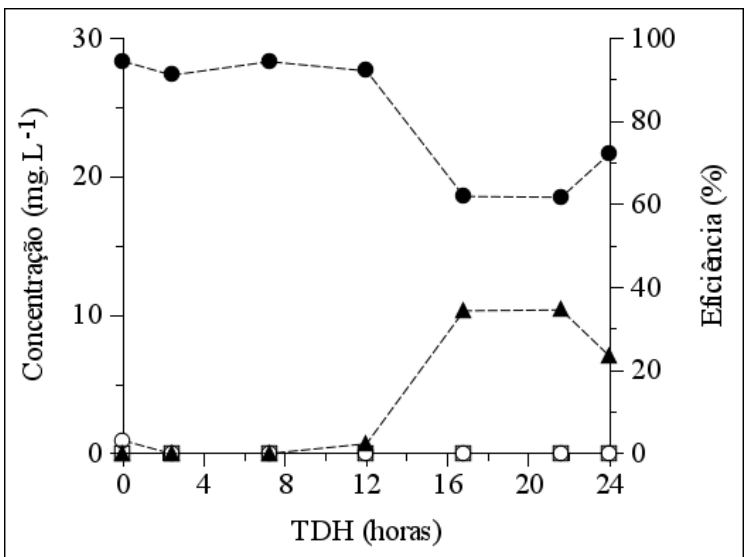

(d)

Figura 5.34. Perfis temporais ao longo do RAHLF da concentração de aldicarbe, sulfóxido de aldicarbe e sulfona de aldicarbe e eficiência de remoção de aldicarbe no Ensaio 5 (a), 10 (b), 20 (c) e 30 (d) sob condições desnitrificantes.

[Notação: -•-, aldicarbe; -o-, sulfóxido de aldicarbe; - $\square-$, sulfona de aldicarbe; - $\boldsymbol{\Delta}$-, eficiência de remoção de aldicarbe.] 


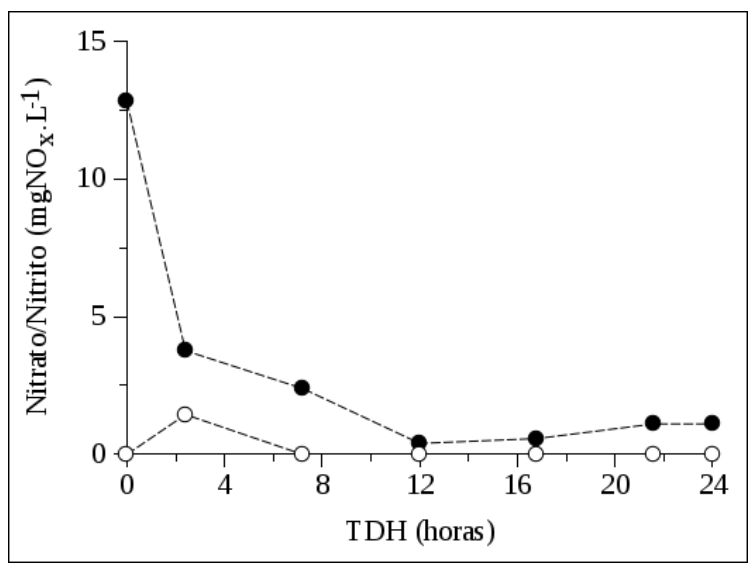

(a)

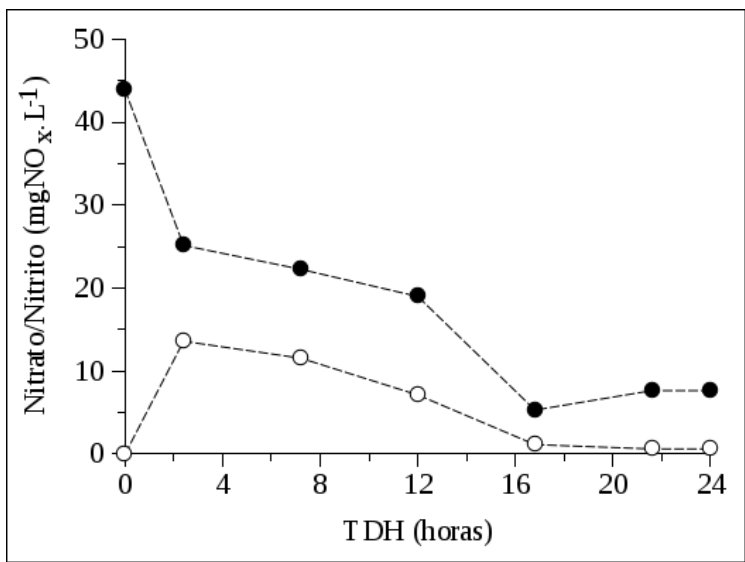

(c)

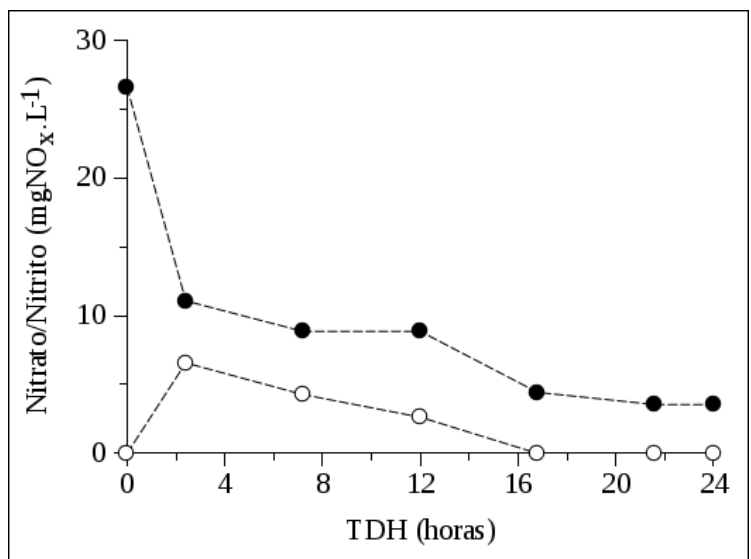

(b)

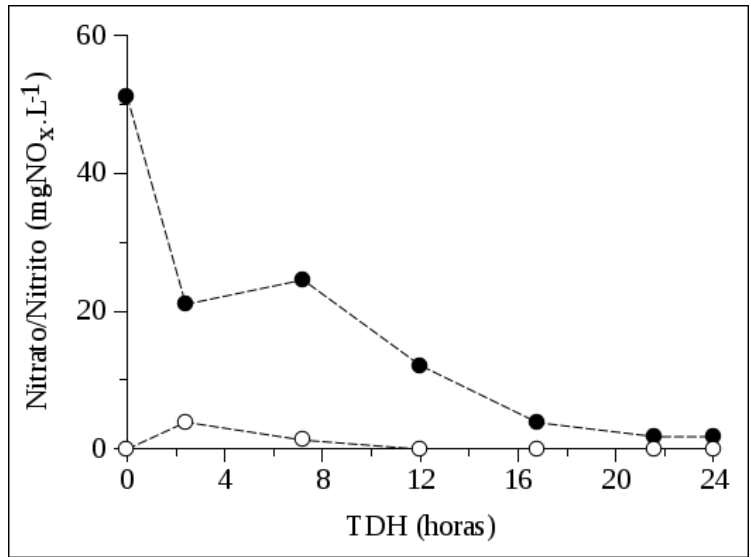

(d)

Figura 5.35. Perfis temporais ao longo do RAHLF da concentração de nitrato e nitrito no Ensaio 5 (a), 10 (b), 20 (c) e 30 (d) sob condições desnitrificantes. [Notação: -•-, nitrato; -०-, nitrito.]

Tabela 5.12. Parâmetros cinéticos aparentes determinados para diferentes concentrações de aldicarbe sob condições desnitrificantes.

\begin{tabular}{cccc}
\hline $\mathrm{C}_{\text {aldicarbe }}\left(\mathrm{mg} \cdot \mathrm{L}^{-1}\right)$ & $\begin{array}{c}\mathrm{k}_{\text {0ap }} \\
\left(\mathrm{mg}_{\text {aldicarbe }} \mathrm{L}^{-1} \cdot \mathrm{h}^{-1}\right)\end{array}$ & $\begin{array}{c}\mathrm{S}_{0} \\
\left(\mathrm{mg}_{\text {aldicarbe }} \cdot \mathrm{L}^{-1}\right)\end{array}$ & $\mathrm{r}^{2}$ \\
\hline 5 & $0,186 \pm 0,013$ & $5,4 \pm 0,2$ & 0,974 \\
10 & $0,465 \pm 0,064$ & $10,4 \pm 1,0$ & 0,911 \\
\hline
\end{tabular}




\subsubsection{Discussão}

Em todas condições de oxidação avaliadas os reatores atingiram elevadas remoções de aldicarbe em período curto, inferior a 45 dias. Entretanto, foram necessários 180 dias de operação para que todos parâmetros de monitoramento se apresentassem aparentemente estáveis, notadamente a concentração de metano no biogás. Em que pese o maior tempo de partida, em todos os níveis de oxidação a adaptação às mudanças de concentração foi rápida, demonstrando a robustez do RAHLF quando submetido a variações da concentração afluente no processo de degradação do aldicarbe.

Durante os ensaios foi detectada a presença de sulfóxido de aldicarbe nas amostras do afluente, possivelmente devido ao procedimento de extração visto que a agitação intensa, com posterior filtração, permitia a oxigenação do meio. Assim, uma fração do aldicarbe era rapidamente convertida a sulfóxido.

A Tabela 5.13 apresenta as eficiências médias de remoção de aldicarbe para os sistemas avaliados em diferentes concentrações de aldicarbe. A variação da eficiência da remoção de aldicarbe com o aumento da concentração pode ser melhor visualizado na Figura 5.36.Verificou-se que, de forma geral, o aumento da concentração de aldicarbe a valores iguais ou maiores que $20 \mathrm{mg} \cdot \mathrm{L}^{-1}$ causou redução gradual da eficiência de conversão, independentemente do nível de oxidação avaliado.

Tabela 5.13. Eficiências médias de remoção de aldicarbe em condições metanogênicas, sulfetogênicas e desnitrificantes.

\begin{tabular}{ccccccc}
\hline \multirow{2}{*}{ Ensaio } & \multicolumn{5}{c}{ Eficiências médias (\%) } \\
\cline { 2 - 7 } & \multicolumn{2}{c}{ Metanogênico } & \multicolumn{2}{c}{ Sulfetogênico } & \multicolumn{2}{c}{ Desnitrificante } \\
\cline { 2 - 7 } & Aldicarbe & $\begin{array}{c}\text { Aldicarbe } \\
\text { total }\end{array}$ & Aldicarbe & $\begin{array}{c}\text { Aldicarbe } \\
\text { total }\end{array}$ & Aldicarbe & $\begin{array}{c}\text { Aldicarbe } \\
\text { total }\end{array}$ \\
\hline 5 & $93,2 \pm 2,2^{(7)}$ & $93,2 \pm 2,2^{(7)}$ & $90,5 \pm 5,1^{(6)}$ & $90,5 \pm 5,1^{(6)}$ & $88,0 \pm 5,9^{(7)}$ & $88,3 \pm 5,9^{(7)}$ \\
10 & $88,9 \pm 8,8^{(7)}$ & $89,2 \pm 8,4^{(7)}$ & $83,2 \pm 4,4^{(7)}$ & $84,4 \pm 4,4^{(7)}$ & $94,3 \pm 2,6^{(7)}$ & $94,7 \pm 2,5^{(7)}$ \\
20 & $76,0 \pm 3,8^{(6)}$ & $76,5 \pm 4,6^{(6)}$ & $80,7 \pm 5,6^{(3)}$ & $79,9 \pm 5,9^{(3)}$ & $32,3 \pm 9,6^{(6)}$ & $32,3 \pm 9,6^{(6)}$ \\
30 & $71,0 \pm 2,7^{(7)}$ & $71,6 \pm 2,7^{(7)}$ & $70,5 \pm 6,1^{(10)}$ & $72,0 \pm 5,8^{(10)}$ & $40,2 \pm 15,0^{(9)}$ & $41,7 \pm 15,0^{(9)}$ \\
40 & $64,4 \pm 3,6^{(6)}$ & $65,1 \pm 4,5^{(6)}$ & $65,3 \pm 2,7^{(6)}$ & $65,7 \pm 3,2^{(6)}$ & - & - \\
\hline
\end{tabular}

* Os números entre parênteses indicam o número de amostras utilizadas para composição da média. 


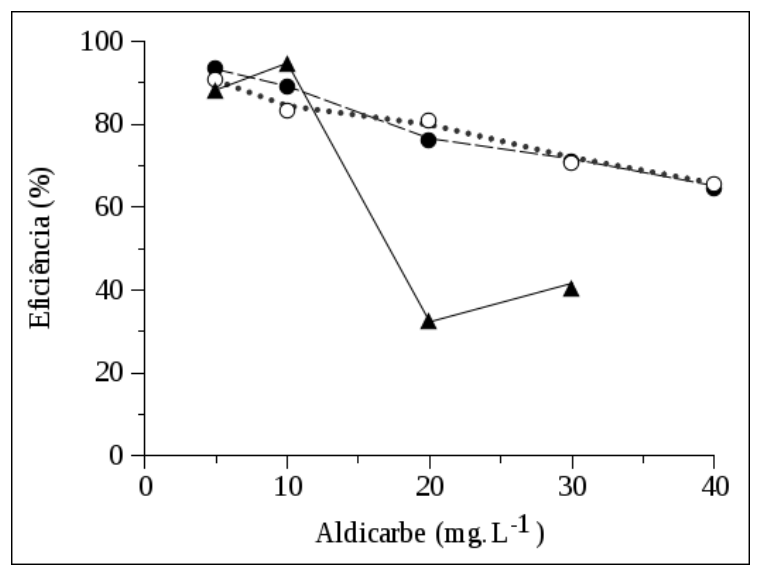

Figura 5.36. Efeito do aumento da concentração afluente de aldicarbe na sua remoção.

[Notação: •, reator metanogênico; o, reator sulfetogênico; $\boldsymbol{\Lambda}$, reator desnitrificante.]

Os reatores metanogênico e sulfetogênico tiveram desempenhos semelhantes durante todos os ensaios, indicando que o nível de oxidação imposto aos mesmos não causou diferenças significativas. Embora tenham sido verificados resultados insatisfatórios para a concentração afluente de 20 e 30 mg. $\mathrm{L}^{-1}$, nas concentrações de 5 e $10 \mathrm{mg} . \mathrm{L}^{-1}$ a eficiência de remoção de aldicarbe no reator desnitrificante foi semelhante aos outros sistemas, chegando a ser ligeiramente superior aos demais na concentração de $10 \mathrm{mg} . \mathrm{L}^{-1}$. Esses resultados diferem dos encontrados por Kazumi e Capone (1995) que, em amostras de sedimentos, determinaram que a velocidade de transformação do aldicarbe na presença de nitrato foi muito superior àquela na sua ausência. Para facilitar a análise do processo foi proposta a relação entre a carga aplicada de aldicarbe (CAA) e a carga removida de aldicarbe (CRA) (Figura 5.37).

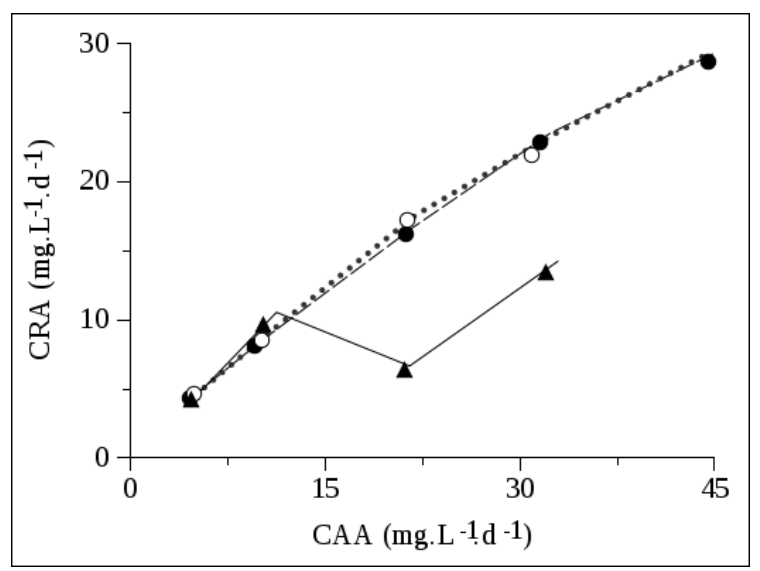

Figura 5.37. Carga removida de aldicarbe (CRA) com o aumento da carga aplicada de aldicarbe (CAA).

[Notação: •, reator metanogênico; o, reator sulfetogênico; $\Delta$, reator desnitrificante.] 
Verifica-se que a CRA foi proporcional à CAA para os reatores metanogênico e sufetogênico, enquanto que, para o sistema desnitrificante, o aumento da CAA para valores superiores a 9,7 mgaldicarbe. $L^{-1} \cdot d^{-1}$ ocasionou ligeira redução da CRA seguido de pequeno aumento, sugerindo a formação de um valor máximo de CRA dentro das condições avaliadas. Assim, o aumento da concentração afluente de aldicarbe, apesar de ter ocasionado queda significativa na eficiência de conversão, não causou efeitos na carga total removida do sistema em condições metanogênicas e sulfetogênicas. Em condições desnitrificantes, o sistema foi mais sensível ao aumento da concentração afluente, indicando que operou próximo à sua capacidade máxima de remoção.

A queda da eficiência de remoção com o aumento da concentração afluente observada nos RAHLFs difere dos resultados obtidos por Kök et al. (1999) que, avaliando a degradação aeróbia de aldicarbe em reator empacotado com Methylosinus imobilizada em microesferas de carboximetilcelulose, determinaram que o aumento da concentração de aldicarbe ocasionou incremento na eficiência de remoção até a concentração afluente de 400 mg.L $\mathrm{L}^{-1}$ (50 a $400 \mathrm{mg} . \mathrm{L}^{-1}$ ), mantendo-se constante em seguida (400 a $800 \mathrm{mg} . \mathrm{L}^{-1}$ ) para o TDH de 2,2 horas. Ademais, apesar dos autores especificarem na descrição do método analítico a avaliação de sulfóxido e sulfona de aldicarbe, não há nenhum resultado experimental ou observação de sua ocorrência ou remoção no decorrer do estudo.

Quando as eficiências de remoção de aldicarbe são comparadas a outros estudos realizados anteriormente, percebe-se que o RAHLF operando em condições anaeróbias obteve desempenho superior aos demais. Kök et al. (1999) obtiveram remoção máxima de aldicarbe de 17,5\%, operando em TDH de 2,2 horas e concentração afluente de $400 \mathrm{mg} . \mathrm{L}^{-1}$. Quando operado em batelada, em 24 horas de tempo de reação, aproximadamente $50 \%$ da concentração inicial foi convertida, atingindo 80\% em 72 horas e 100\% em 96 horas na concentração de 100 mg. $\mathrm{L}^{-1}$. Rose et al. (2006) operaram um sistema de alagados construídos e a remoção de aldicarbe variou de 15 a 39\% para concentrações afluentes inferiores a $90 \mu \mathrm{g} \cdot \mathrm{L}^{-1}$.

Nas amostras do efluente dos reatores não foram detectados sulfóxido e sulfona de aldicarbe, confirmando que, em condições anaeróbias, os mesmos não são formados. Assim, na ausência de oxigênio, as vias de degradação são deslocadas para formação de oximas e nitrilas (Andrawes, 1971). Essa observação condiz com o que foi verificado por Kazumi e Capone (1995) e Vink e Van Der Zee (1997). Uma vez que as nitrilas e as oximas do aldicarbe e metabólitos exercem menor toxicidade, o potencial de toxicidade é reduzido. Entretanto, há de se levar em consideração o efeito conjunto desses compostos pelo emprego 
de testes ecotoxicológicos. Nesse contexto, Martins et al. (2007) verificaram a aplicabilidade de bioensaios com microcrustáceos (Daphnia similis) para avaliação da eficiência de remoção de aldicarbe no RAHLF. Foram avaliadas amostras do reator metanogênico com concentração afluente de $50 \mathrm{mg} . \mathrm{L}^{-1}$, reator sulfetogênico com concentração afluente de 20 e $50 \mathrm{mg} . \mathrm{L}^{-1}$ e reator desnitrificante com concentração afluente de $20 \mathrm{mg} . \mathrm{L}^{-1}$. Observou-se maior redução da toxicidade no reator sulfetogênico em relação aos demais, com o número de Unidades Tóxicas (UT) das amostras do afluente reduzindo de 34 para 9,3 (73\%) e de 71 para 8 (88\%) após a degradação no reator nas concentrações afluentes de 20 e 50 mg. $\mathrm{L}^{-1}$, respectivamente. Para o sistema metanogênico e desnitrificante a redução no número de UT foi de 55 para 41 (25\%) e de 41 para 31 (24\%), respectivamente.

Os perfis temporais de aldicarbe revelaram variação semelhante entre o reator metanogênico e o reator sulfetogênico, ambos com cinética de degradação de primeira ordem. No reator desnitrificante, entretanto, a cinética de ordem zero foi a que representou melhor o sistema. Na Figura 5.38 é apresentada a variação das constantes cinéticas aparentes em função da concentração afluente de aldicarbe.

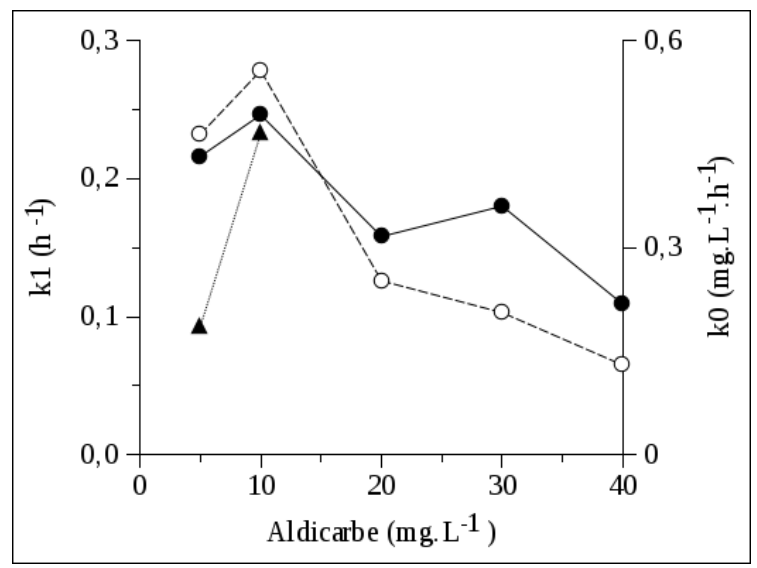

Figura 5.38. Variação do parâmetro cinético aparente de degradação de primeira ordem ( $\left.\mathrm{k}_{1 \mathrm{ap}}\right)$ e ordem zero $\left(\mathrm{k}_{0 \mathrm{ap}}\right)$

[Notação: •, reator metanogênico; ○, reator sulfetogênico; $\boldsymbol{\Delta}$, reator desnitrificante.]

Embora o desempenho na remoção de aldicarbe tenha sido semelhante, observou-se que o coeficiente cinético aparente foi diferente quando os reatores foram submetidos ao aumento da concentração de aldicarbe. Nas menores concentrações (5 e 10 mg.L ${ }^{-1}$ ), os valores de $k_{1 a p}$ foram próximos, enquanto que nas maiores concentrações houve redução no seu valor, sendo esta mais acentuada para o sistema sulfetogênico. O melhor ajuste dos dados experimentais do reator desnitrificante ao modelo cinético de ordem zero pode sugerir que o 
mesmo trabalhou em condições limítrofes de degradação, próximo às velocidades máximas. Um indicativo de que esta suposição seja verdadeira é a estabilidade da carga removida de aldicarbe com o aumento da concentração afluente. Assim, para as condições estabelecidas, o sistema desnitrificante demonstrou maior sensibilidade nas concentrações avaliadas.

Considerando o modelo cinético de Monod (MONOD, 1942), em concentrações elevadas o sistema reacional tem comportamento típico de ordem zero. Entretanto para o modelo cinético proposto por Andrews para substrato limitante e inibidor (ANDREWS, 1968), o aumento da concentração de substrato reduzirá a velocidade de conversão do mesmo, reduzindo sua constante cinética. A variação do parâmetro cinético, quando a concentração aumenta de 5 para $10 \mathrm{mg} . \mathrm{L}^{-1}$ reduzindo em seguida pode ser um indicativo do início do processo de inibição, em que atinge-se um valor máximo com redução posterior. Kök et al. (1999), embora tenham observado a manutenção da eficiência de remoção de aldicarbe com o aumento da sua concentração afluente, verificaram redução nas velocidades de conversão o que, supostamente, reduziu os coeficientes cinéticos de degradação.

Nos três sistemas não foram detectadas alterações significativas do $\mathrm{pH}$ em todas concentrações avaliadas, demostrando que a alcalinidade adicionada ao meio sintético foi suficiente para manter o tamponamento durante o processo de degradação. 


\subsection{Cinética da degradação biológica do aldicarbe sob condições metanogênicas - Experimento em reatores diferenciais}

\subsubsection{Avaliação da transferência de massa externa e interna}

Na Figura 5.39 encontram-se as curvas ajustadas para os perfis de concentração de aldicarbe no meio líquido $\left(\mathrm{S}_{\mathrm{b}}\right)$ em função do tempo para as diferentes velocidades de escoamento superficial. Os parâmetros ajustados da Equação 4.11 aos dados experimentais são mostrados na Tabela 5.14. A concentração de biomassa determinada nos reatores diferenciais foi de $3115 \pm 19$ mgSVT. - $^{-1}$.

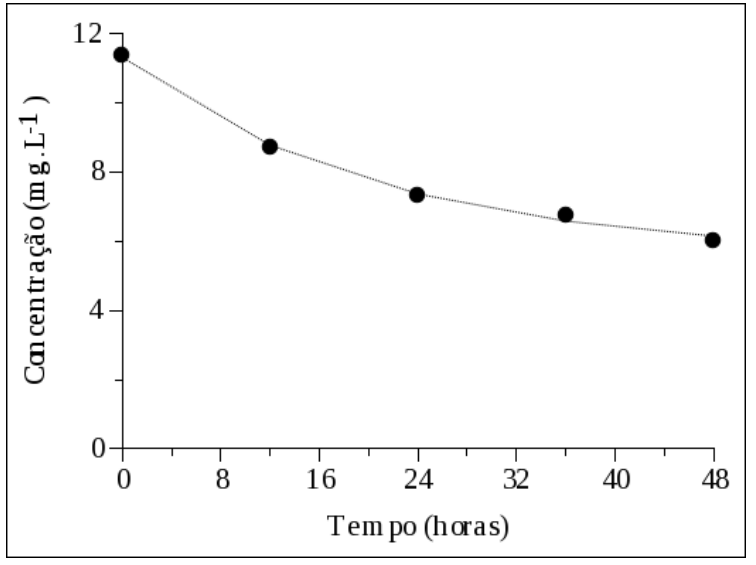

(a)

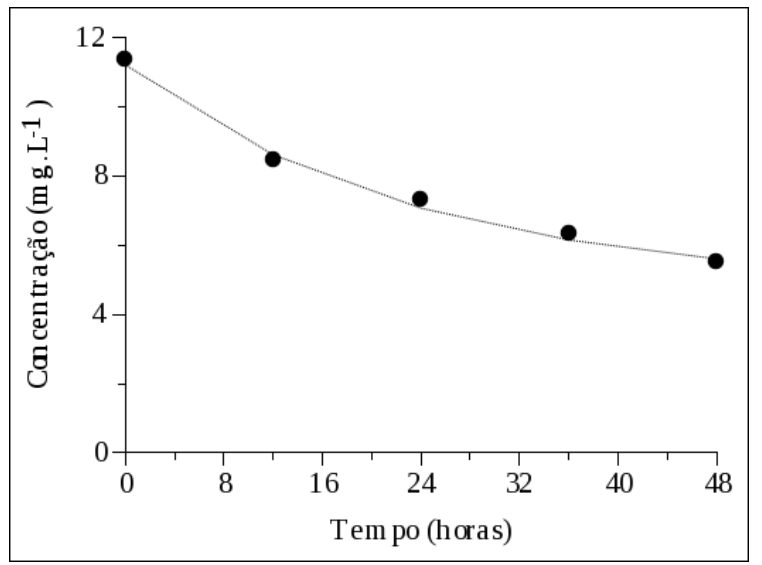

(c)

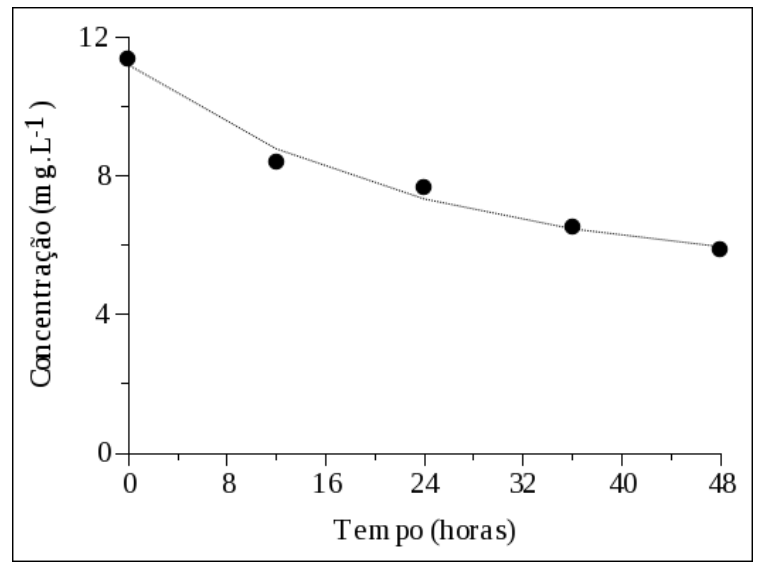

(b)

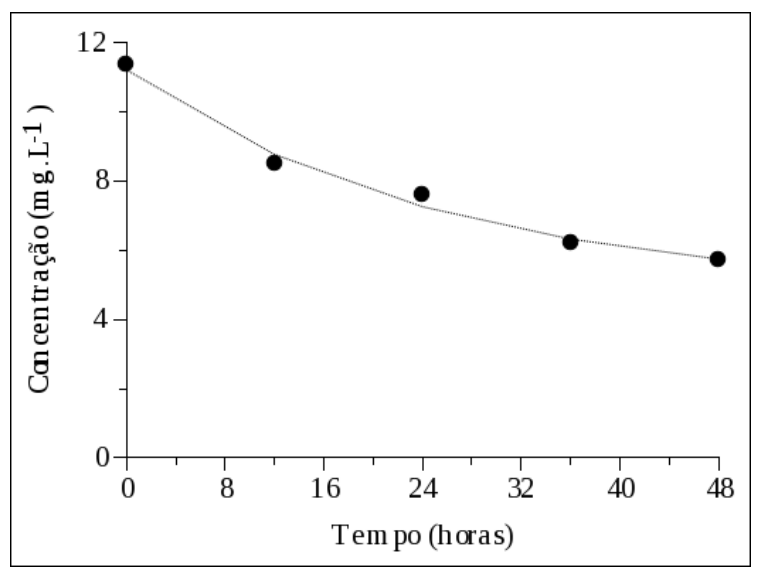

(d)

Figura 5.39. Perfil de concentração de aldicarbe no meio líquido em função do tempo para as velocidades de escoamento de 4,2 (a), 25,5 (b), 78,3 (c) e 203,7 cm.h $\mathrm{h}^{-1}$ (d). 
Tabela 5.14. Parâmetros da equação exponencial ajustados para os ensaios com reator diferencial.

\begin{tabular}{ccccc}
\hline $\mathrm{v}_{\mathrm{s}}\left(\mathrm{cm} \cdot \mathrm{h}^{-1}\right)$ & $\mathrm{y}_{0}{ }^{*}$ & $\mathrm{~A}^{*}$ & $\mathrm{~T}^{*}$ & $\mathrm{r}^{2^{*}}$ \\
\hline 4,2 & $5,6 \pm 0,4$ & $5,7 \pm 0,4$ & $20,4 \pm 3,5$ & 0,995 \\
25,5 & $5,2 \pm 0,9$ & $6,0 \pm 0,9$ & $23,2 \pm 8,4$ & 0,983 \\
78,3 & $4,8 \pm 0,6$ & $6,4 \pm 0,6$ & $23,1 \pm 5,2$ & 0,993 \\
203,7 & $4,8 \pm 0,9$ & $6,4 \pm 0,8$ & $25,0 \pm 7,6$ & 0,989 \\
\hline
\end{tabular}

$S_{b}=y_{0}+A \cdot \mathrm{e}^{\frac{-t}{T}}$

A velocidade inicial de consumo de substrato observada $\left(R_{o b s}\right)$ e a velocidade inicial específica de consumo de substrato observada $\left(\mathrm{r}_{\mathrm{obs}}\right)$ foram determinadas a partir das Equações 4.12 e 4.13 e são apresentadas na Tabela 5.15. O módulo de Thiele observado ( $\left.\phi_{\mathrm{obs}}\right)$, determinado a partir da Equação 4.14, também é apresentado.

Tabela 5.15. Velocidade inicial de consumo de substrato observada $\left(\mathrm{R}_{\mathrm{obs}}\right)$, velocidade inicial específica de consumo de substrato observada ( $\mathrm{r}_{\mathrm{obs}}$ ) e módulo de Thiele observado ( $\left.\phi_{\mathrm{obs}}\right)$ para as diferentes velocidades de escoamento superficial.

\begin{tabular}{cccc}
\hline $\mathrm{V}_{\mathrm{s}}\left(\mathrm{cm} \cdot \mathrm{h}^{-1}\right)$ & $\begin{array}{c}\mathrm{R}_{\mathrm{obs}, \mathrm{t}=0} \\
\left(\mathrm{mg}_{\text {aldicarbe }} \mathrm{L}^{-1} \cdot \mathrm{h}^{-1}\right)\end{array}$ & $\begin{array}{c}\mathrm{r}_{\mathrm{obs}, \mathrm{t}=0} \\
\left(\mathrm{mg}_{\text {aldicarbe }} \cdot \mathrm{mgSVT}^{-1} \cdot \mathrm{h}^{-1}\right)\end{array}$ & $\phi_{\text {obs }}$ \\
\hline 4,2 & 0,279 & $8,97 \cdot 10^{-5}$ & 0,0091 \\
25,5 & 0,259 & $8,30 \cdot 10^{-5}$ & 0,0084 \\
78,3 & 0,277 & $8,89 \cdot 10^{-5}$ & 0,0091 \\
\hline
\end{tabular}

O aumento da velocidade de escoamento não resultou em aumento nas velocidades de consumo de substrato para a concentração de aldicarbe de $10 \mathrm{mg} \cdot \mathrm{L}^{-1}$. Ou seja, o aumento em até, aproximadamente, 50 vezes da velocidade de escoamento não influenciou no fluxo de massa da fase líquida para a matriz com biomassa imobilizada. Verificou-se que o módulo de Thiele observado foi muito inferior aos preconizados por Bringi e Dale $(1990)\left(\phi_{\mathrm{obs}}<0,3\right)$ para que a transferência de massa interna seja desprezada. Assim, conclui-se que, nessas condições, as resistências à transferência de massa externa e interna podem ser consideradas desprezíveis, sendo a velocidade global de consumo de substrato limitada somente à cinética de reação. 


\subsubsection{Determinação dos parâmetros cinéticos intrínsecos de degradação}

Como a velocidade de consumo de substrato não sofreu efeitos da resistência à transferência de massa, tanto externa quanto interna, os parâmetros cinéticos determinados nessas condições correspondem aos parâmetros cinéticos intrínsecos de degradação.

Na Figura 5.40 é apresentada a variação da velocidade específica de consumo de substrato observada $\left(\mathrm{r}_{\mathrm{obs}}\right)$ para as diferentes velocidades de escoamento superficial. Percebe-se a tendência linear dos dados experimentais e a ocorrência de uma concentração mínima para que a velocidade de consumo seja maior do que zero.

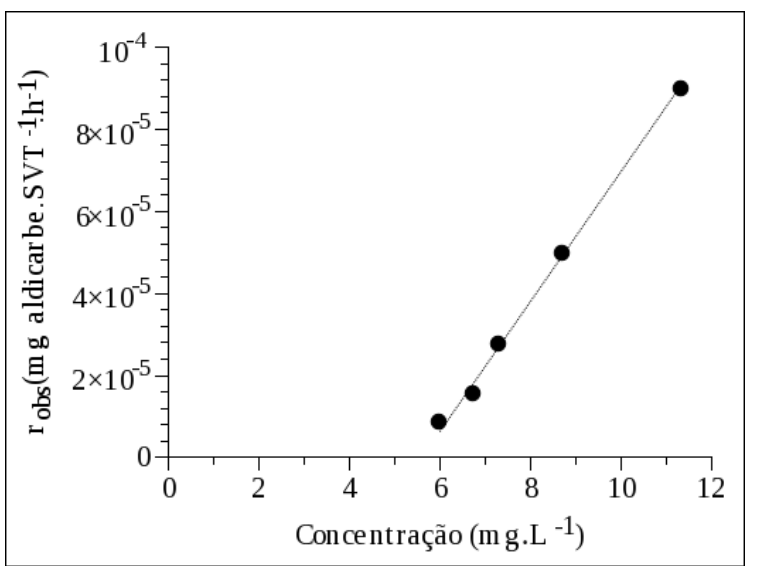

(a)

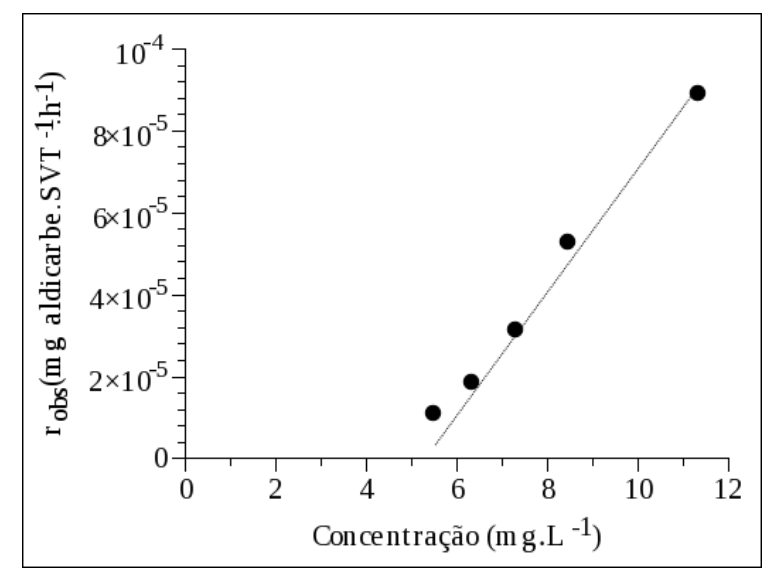

(c)

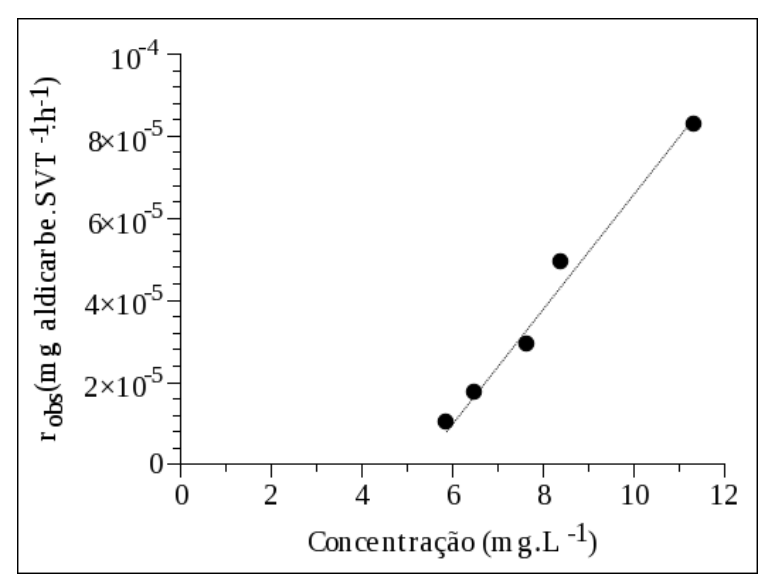

(b)

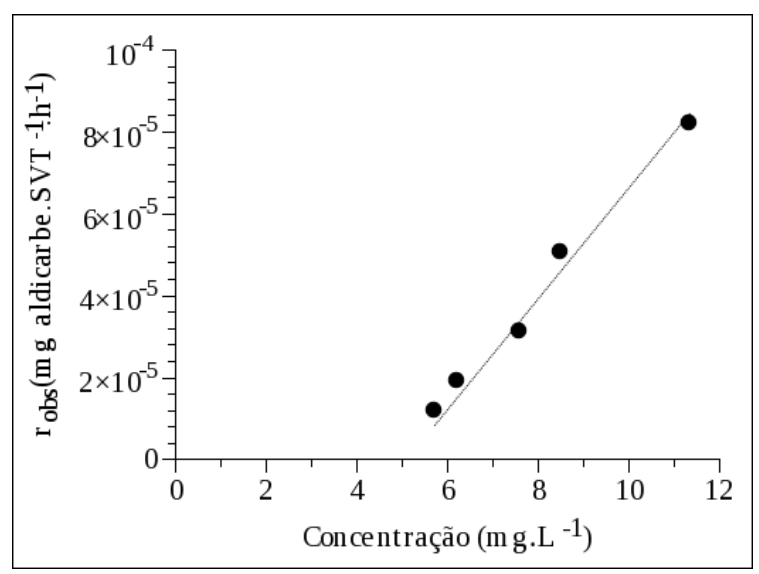

(d)

Figura 5.40. Perfil de $\mathrm{r}_{\mathrm{obs}}$ em função da concentração de substrato no meio líquido para as velocidades de escoamento de 4,2 (a), 25,5 (b), 78,3 (c) e 203,7 cm.h $\mathrm{h}^{-1}$ (d).

Assim, a Equação 4.16 foi ajustada aos dados experimentais de forma a obter a constante cinética de degradação de primeira ordem $\left(\mathrm{k}_{1}\right)$ e concentração mínima de substrato $\left(S_{\text {min }}\right)$ em cada ensaio (Tabela 5.16). Como pode ser observado, os valores de $k_{1}$ e $S_{\text {min }}$ oscilam em torno de seus respectivos valores médios, sendo estes considerados como os parâmetros 
cinéticos intrínsecos de degradação $\left(\mathrm{k}_{1}=1,46 \pm 0,09 \cdot 10^{-5} \mathrm{~L} \cdot \mathrm{mgSVT}^{-1} \cdot \mathrm{h}^{-1}\right.$ e $\mathrm{S}_{\min }=$ $\left.5,3 \pm 0,2 \mathrm{mg}_{\text {aldicarbe }} \cdot \mathrm{L}^{-1}\right)$.

Tabela 5.16. Parâmetros cinéticos determinados empregando-se reatores diferenciais para diferentes velocidades de escoamento superficial.

\begin{tabular}{cccc}
\hline $\mathrm{V}_{\mathrm{s}}\left(\mathrm{cm} \cdot \mathrm{h}^{-1}\right)$ & $\mathrm{k}_{1}$ & $\begin{array}{c}\mathrm{S}_{\min } \\
\left(10^{-5} \cdot \mathrm{L} \cdot \mathrm{mgSVT}^{-1} \cdot \mathrm{h}^{-1}\right)\end{array}$ & $\mathrm{r}^{2}$ \\
\hline 4,2 & $1,58 \pm 0,06$ & $5,6 \pm 0,1$ & 0,995 \\
25,5 & $1,40 \pm 0,05$ & $5,3 \pm 0,1$ & 0,995 \\
78,3 & $1,50 \pm 0,06$ & $5,3 \pm 0,1$ & 0,995 \\
203,7 & $1,35 \pm 0,07$ & $5,1 \pm 0,2$ & 0,992 \\
\hline Média & $1,46 \pm 0,09$ & $5,3 \pm 0,2$ & $0,994 \pm 0,001$ \\
\hline
\end{tabular}

Para avaliar os parâmetros cinéticos determinados a partir dos reatores diferenciais, foram determinados os parâmetros cinéticos a partir dos perfis de degradação de aldicarbe no RAHLF sob condições metanogênicas. Como a resistência à transferência de massa interna e externa não exerceu efeito significativo sobre a velocidade global de degradação, os parâmetros cinéticos aparentes correspondem aos parâmetros cinéticos intrínsecos.

Assim, foi determinada a concentração média de biomassa no meio suporte, após a operação no Ensaio 40. A concentração encontrada foi de $290 \pm 74$ mgSVT.gespuma ${ }^{-1}$. Considerando a quantidade de biomassa como sendo constante, a concentração média ao longo do RAHLF foi de 10875 mgSVT.L ${ }^{-1}$. Na Tabela 5.17 são apresentados os parâmetros cinéticos de degradação do aldicarbe em condições metanogênicas, tanto no RAHLF quanto nos reatores diferenciais.

Observa-se que os valores de $\mathrm{k}_{1}$ oscilam em torno de um valor médio, sendo que este foi muito próximo ao valor determinado nos reatores diferenciais. Em contrapartida, percebese a variação dos valores de $S_{\min }$, aumentando com o aumento da concentração afluente. Houve também diferença significativa entre os valores de $S_{\min }$ determinados na mesma concentração entre o RAHLF e os reatores diferenciais. Essa observação pode representar o efeito da razão entre a quantidade de substrato (aldicarbe) e a quantidade de biocatalisador (biomassa). Assim, em função dessa relação, $S_{\min }$ pode variar em diferentes experimentos, mesmo com concentrações afluentes semelhantes. Portanto, nesses casos, o emprego desse parâmetro deve ser feito com cautela. 
Tabela 5.17. Parâmetros cinéticos de degradação do aldicarbe sob condições metanogênicas no RAHLF e no reator diferencial

\begin{tabular}{|c|c|c|c|c|}
\hline \multirow{2}{*}{$\begin{array}{l}\text { Aldicarbe } \\
\left(\mathrm{mg}^{-1} \mathrm{~L}^{-1}\right)\end{array}$} & \multicolumn{2}{|c|}{ RAHLF } & \multicolumn{2}{|c|}{ Reator diferencial } \\
\hline & $\begin{array}{c}\mathrm{k}_{1} \\
\left(10^{-5} \cdot \mathrm{L} \mathrm{mgSVT}^{-1} \cdot \mathrm{h}^{-1}\right)\end{array}$ & $\begin{array}{c}\mathrm{S}_{\min } \\
\left(\mathrm{mg}_{\text {aldicarbe }} \cdot \mathrm{L}^{-1}\right)\end{array}$ & $\begin{array}{c}\mathrm{k}_{1} \\
\left(10^{-5} \cdot \mathrm{L} \cdot \mathrm{mgST}^{-1} \cdot \mathrm{h}^{-1}\right)\end{array}$ & $\begin{array}{c}\mathrm{S}_{\min } \\
\left(\mathrm{mg}_{\text {aldicarbe }} \mathrm{L}^{-1}\right)\end{array}$ \\
\hline 5 & $1,98 \pm 0,18$ & $0,3 \pm 0,1$ & - & - \\
\hline 10 & $2,26 \pm 0,18$ & $1,1 \pm 0,2$ & $1,46 \pm 0,09$ & $5,3 \pm 0,2$ \\
\hline 20 & $1,45 \pm 0,14$ & $4,8 \pm 0,5$ & - & - \\
\hline 30 & $1,65 \pm 0,46$ & $6,3 \pm 1,5$ & - & - \\
\hline 40 & $1,00 \pm 0,34$ & $14,3 \pm 3,7$ & - & - \\
\hline Média & $1,65 \pm 0,49$ & - & - & - \\
\hline
\end{tabular}

\subsubsection{Validação dos parâmetros cinéticos intrínsecos}

Propôs-se a validação dos parâmetros cinéticos intrínsecos pela comparação dos perfis temporais ao longo do RAHLF determinados experimentalmente e perfis temporais simulados pelo modelo cinético de primeira ordem com residual empregando-se simultaneamente parâmetros determinados nos reatores diferenciais e no RAHLF. Como ferramenta de tomada de decisão, propôs-se o emprego do Teste F de acordo com procedimento apresentado por Bonomi e Schmidell (2001). Esse teste permite avaliar se o modelo proposto representa satisfatoriamente o conjunto de dados experimentais.

O valor da concentração inicial de aldicarbe no perfil $\left(\mathrm{S}_{0}\right)$ utilizado na simulação foi o correspondente ao primeiro ponto experimental do perfil temporal da concentração de aldicarbe ao longo do RAHLF operando em condições metanogênicas (Figura 5.19), para cada concentração avaliada. Em função das diferenças nos valores de $S_{\min }$ no RAHLF e nos reatores diferenciais, ajustou-se uma equação polinomial de segunda ordem aos valores experimentais determinados a partir dos perfis temporais, tornando possível a avaliação da variação de $S_{\min }$ com o aumento da concentração afluente de aldicarbe. Isso pode ser observado na Figura 5.41. Na Tabela 5.18 são apresentados os parâmetros ajustados. Assim, em função da concentração inicial, obteve-se a respectiva concentração mínima de substrato. A constante cinética de primeira ordem $\left(\mathrm{k}_{1}\right)$ empregada foi a determinada nos reatores diferenciais. Os valores utilizados na simulação dos perfis são mostrados na Tabela 5.19.

Na Figura 5.42 são mostrados os perfis temporais da concentração de aldicarbe ao longo do RAHLF em condições metanogênicas, para os valores experimentais e valores simulados pelo modelo de degradação. 


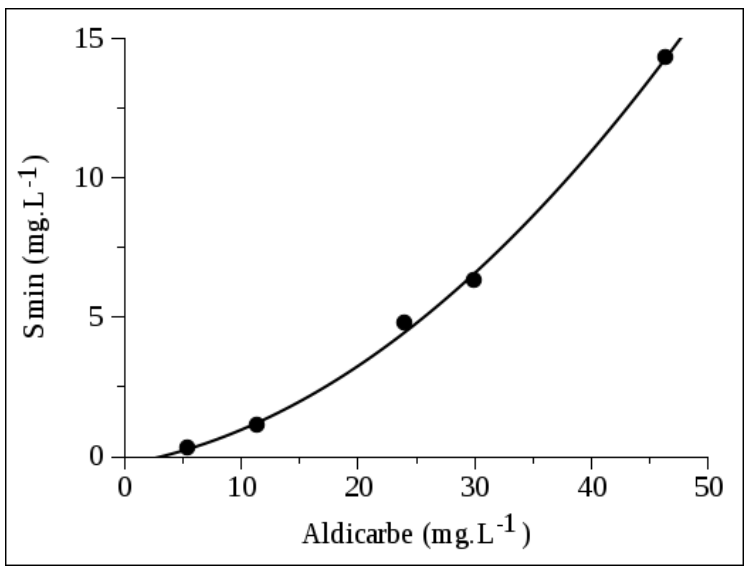

Figura 5.41. Variação da concentração mínima de substrato com o aumento da concentração de aldicarbe no RAHLF.

[Notação: •, valores experimentais; —, equação ajustada.]

Tabela 5.18. Parâmetros da equação polinomial de segunda ordem.

\begin{tabular}{cccc}
\hline $\mathrm{a}$ & $\mathrm{b}$ & $\mathrm{c}$ & $\mathrm{r}^{2}$ \\
\hline 0,00523354 & 0,0716811 & $-0,274084$ & 0,998 \\
\hline
\end{tabular}

Tabela 5.19. Parâmetros utilizados na simulação dos perfis temporais.

\begin{tabular}{ccccc}
\hline $\begin{array}{c}\text { Aldicarbe } \\
\left(\mathrm{mg} \cdot \mathrm{L}^{-1}\right)\end{array}$ & $\begin{array}{c}\mathrm{S}_{0} \\
\left(\mathrm{mg}_{\text {aldicarbe. }} \mathrm{L}^{-1}\right)\end{array}$ & $\begin{array}{c}\mathrm{S}_{\min } \\
\left(\mathrm{mg}_{\text {aldicarbe. }} \mathrm{L}^{-1}\right)\end{array}$ & $\begin{array}{c}\mathrm{k}_{1} \\
\left(10^{-5} \cdot \mathrm{L}_{\mathrm{mgSVT}} \mathrm{mg}^{-1}\right)\end{array}$ & $\begin{array}{c}\mathrm{X} \\
\left(\mathrm{mgSVT} \cdot \mathrm{L}^{-1}\right)\end{array}$ \\
\hline 5 & 5,4 & 0,3 & & \\
10 & 11,4 & 1,2 & & \\
20 & 24 & 4,5 & 1,46 & 10875 \\
30 & 30 & 6,6 & & \\
40 & 46,3 & 14,3 & & \\
\hline
\end{tabular}

Os parâmetros determinados para avaliação estatística do ajuste do modelo aos dados experimentais são apresentados na Tabela 5.20.

Tabela 5.20. Parâmetros determinados para emprego do Teste F.

\begin{tabular}{cc}
\hline $\mathrm{s}_{\mathrm{c}}{ }^{2}$ & $\varepsilon(\%)$ \\
\hline 3,693 & 11,7 \\
\hline
\end{tabular}

O resultado indica que, se o erro experimental dos dados disponíveis for maior que 11,7\%, o modelo utilizado na simulação dos perfis experimentais é considerado adequado, segundo o Teste F modificado. Se for considerado que, em processos fermentativos, a falta de 
reprodutibilidade, a dificuldade em se manter condições homogêneas dentro do biorreator e os próprios erros analíticos e de amostragem comuns na atividade laboratorial (BONOMI; SCHMIDELL, 2001) são fontes acumulativas de erros, conclui-se que o modelo utilizado é adequado, representando, com significância estatística, os dados experimentais.

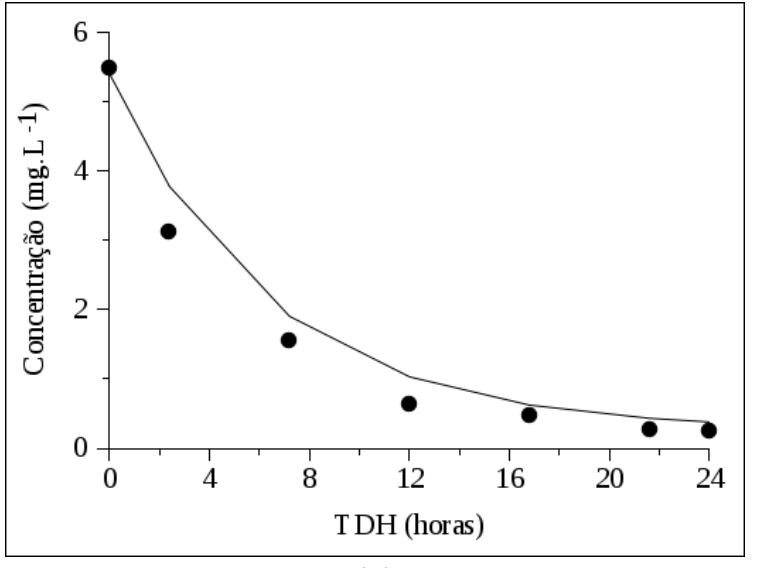

(a)

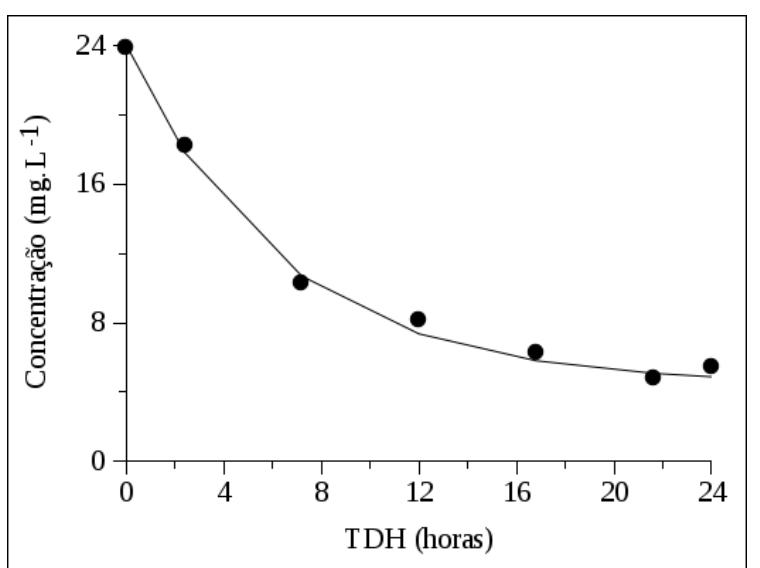

(c)

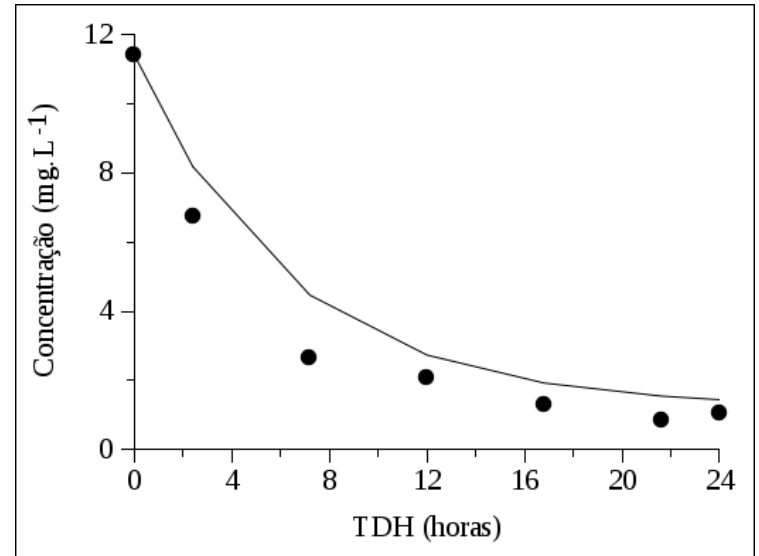

(b)

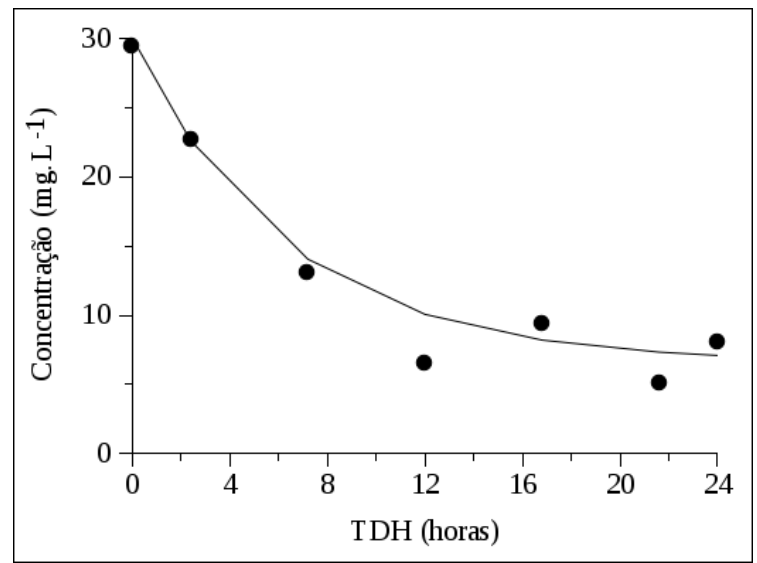

(d)

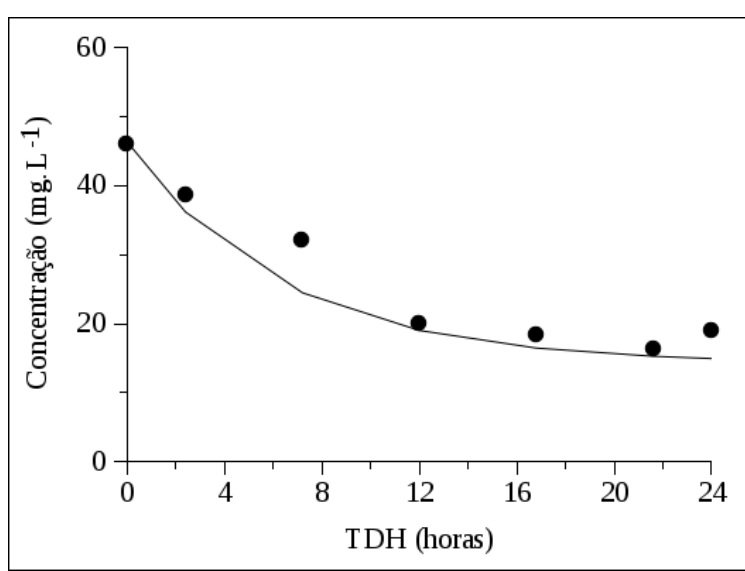

(e)

Figura 5.42. Perfis temporais ao longo do RAHLF da concentração experimental e simulada de aldicarbe no Ensaio 5 (a), 10 (b), 20 (c), 30 (d) e 40 (e) sob condições metanogênicas. 


\subsection{Caracterização microbiológica da degradação do aldicarbe no RAHLF}

\subsubsection{Microscopia ótica}

Após a realização dos ensaios com a última concentração afluente de aldicarbe, foram coletadas amostras das matrizes com biomassa imobilizada para exames microbiológicos nos três reatores utilizados. Algumas morfologias observadas na microscopia de contraste de fase e epifluorescência são apresentadas nas Figuras 5.43 a 5.45 para o RAHLF operando sob condições metanogênicas, sulfetogênicas e desnitrificantes, respectivamente. Na Tabela 5.21 são apresentados, em escala quantitativa, os microorganismos encontrados nas amostras avaliadas.

Observou-se nas amostras a presença excessiva de material polimérico junto à biomassa, indicando que os organismos estariam submetidos a uma condição de estresse. Como os polímeros extracelulares formam uma camada protetora às células, podem ter desempenhado a função de proteger os microorganismos das substâncias tóxicas presentes no meio.

Em todos reatores foi observada a presença de bacilos e cocos fluorescentes semelhantes às metanogênicas hidrogenotróficas. Não foi observada estrutura semelhante à Methanosarcina, organismo capaz de metabolizar metilamina (um dos produtos finais da degradação de aldicarbe). A presença de Methanosaeta foi confirmada em todos os reatores. 
Tabela 5.21. Ocorrência das morfologias observadas nas amostras de biomassa imobilizada.

\begin{tabular}{lccc}
\hline \multirow{2}{*}{ Morfologia } & \multicolumn{3}{c}{ RAHLF } \\
\cline { 2 - 4 } & Metanogênico & Sulfetogênico & Desnitrificante \\
\hline Arquéias metanogênicas & & & - \\
Methanosarcina sp. & - & - & ++ \\
Methanosaeta sp. & +++ & ++ & +++ \\
Bacilos fluorescentes & +++ & +++ & ++ \\
Bactérias & & & ++ \\
Bacilos & +++ & ++ & ++ \\
Bacilos curvos & ++ & ++ & +++ \\
Cocos & ++ & +++ & + \\
Filamentos & +++ & ++ & + raros, $(-)$ não foram observados. \\
Notação: $(++++)$ predominantes, $(+++)$ freqüentes, $(++)$ pouco freqüentes, $(+)$ rar
\end{tabular}




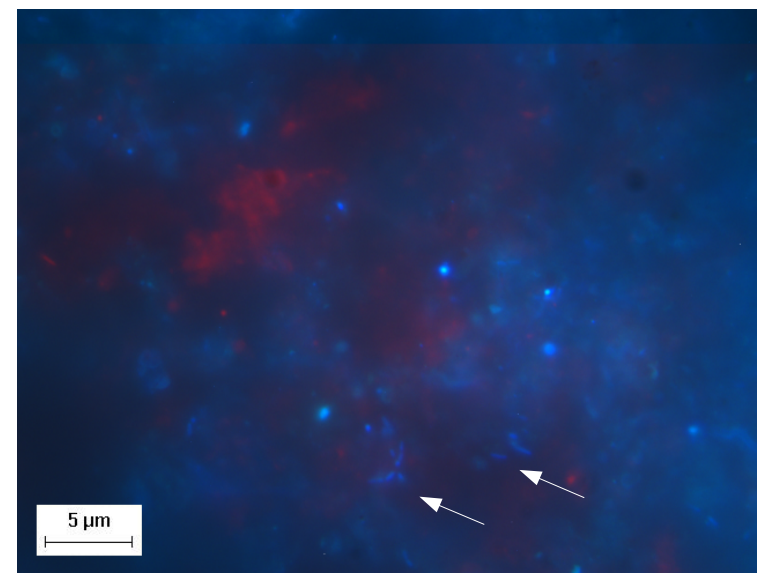

(a)

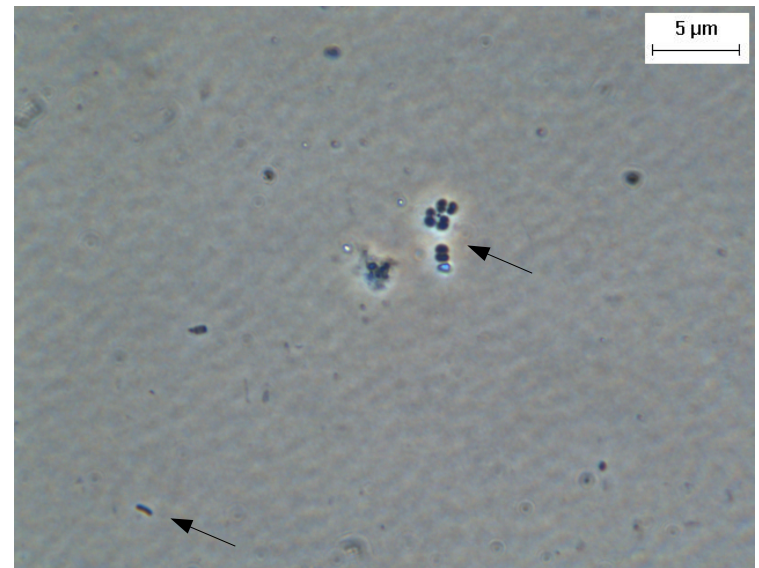

(c)

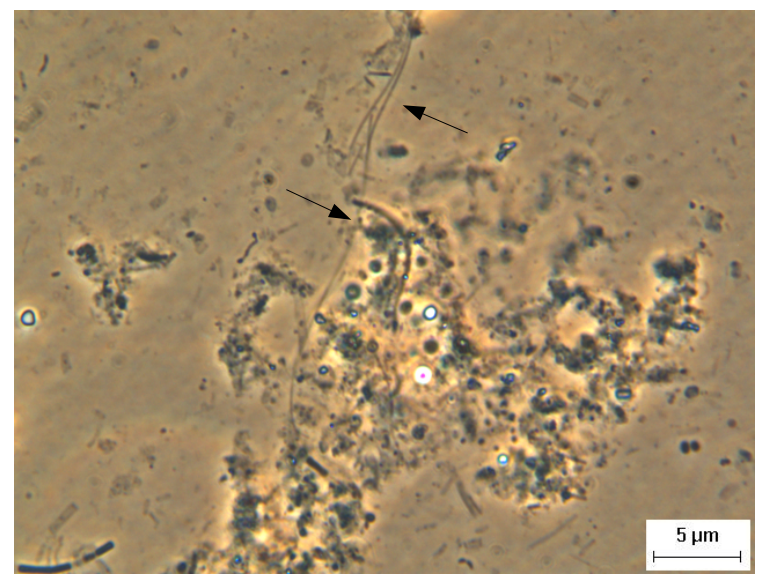

(e)

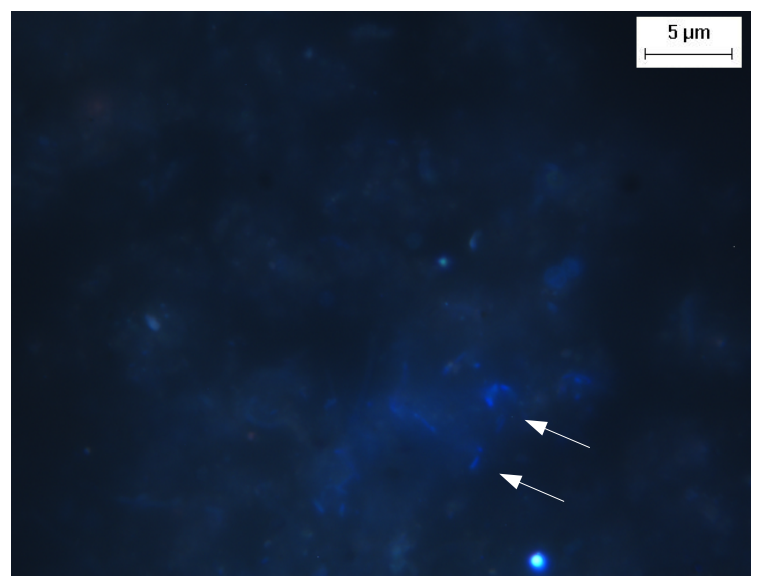

(b)

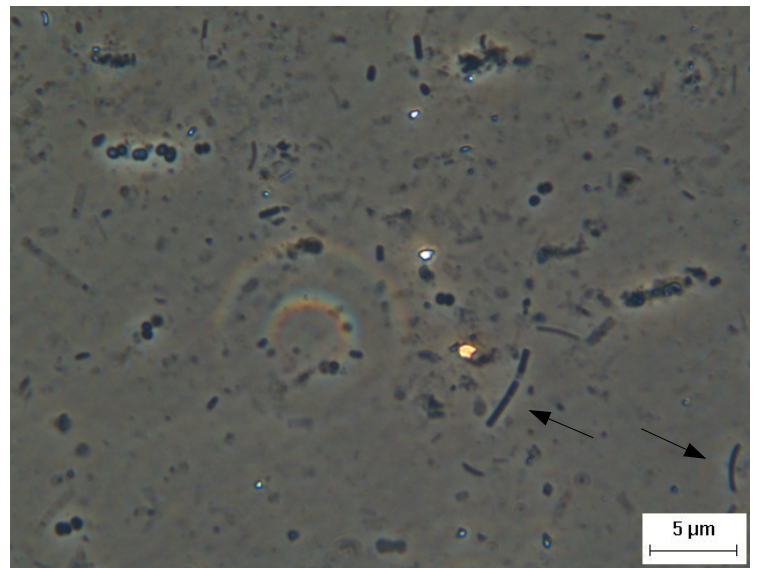

(d)

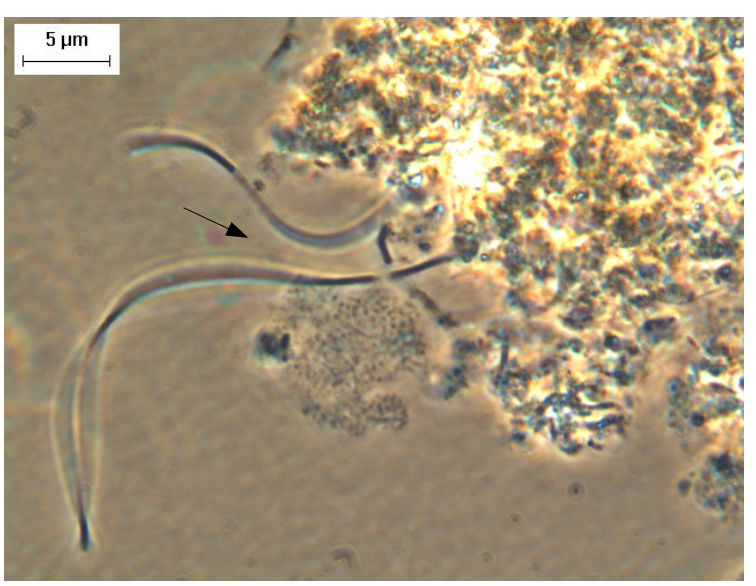

(f)

Figura 5.43. Observações morfológicas sob microscopia de contraste de fase e epifluorescência, referentes às amostras do reator metanogênico.

[Notação: (a) e (b) bacilos fluorescentes semelhantes às metanogênicas hidrogenotróficas; (c) e (d) bacilos diversos, cocos e filamentos; (e) bacilos delgados não fluorescentes e morfologia semelhante a Methanosaeta.;

(f) morfologia semelhante a Methanosaeta.] 


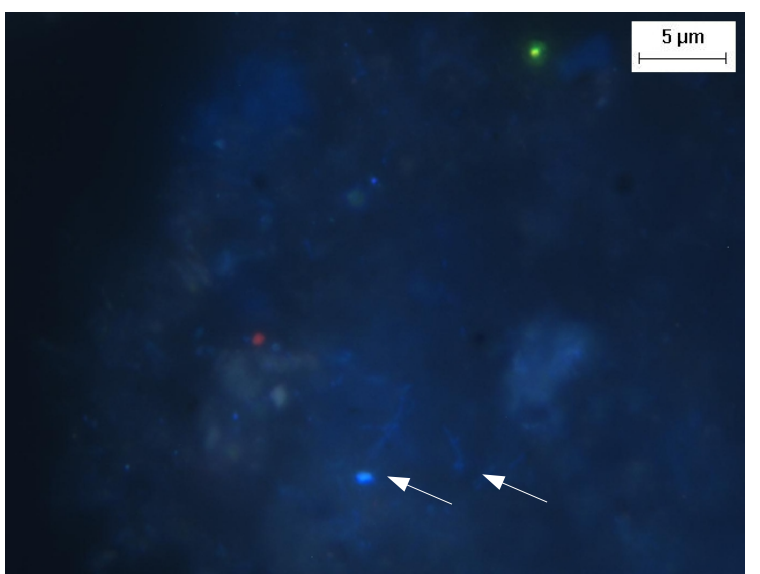

(a)

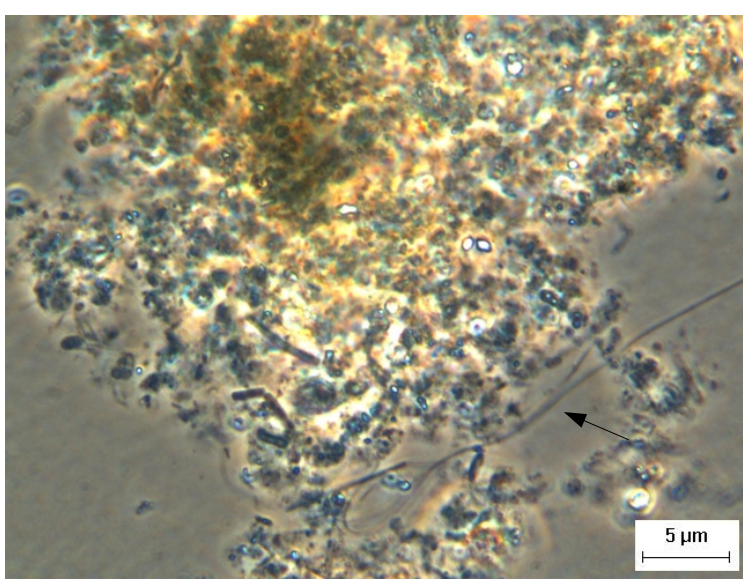

(c)

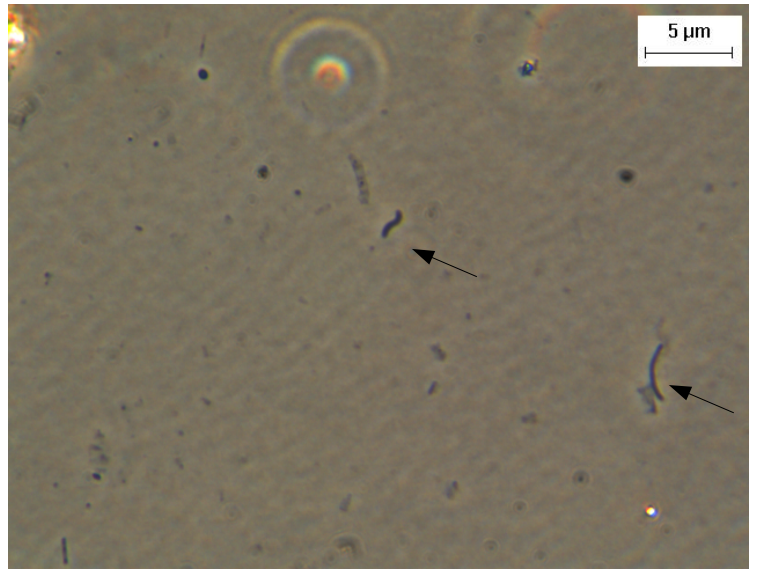

(e)

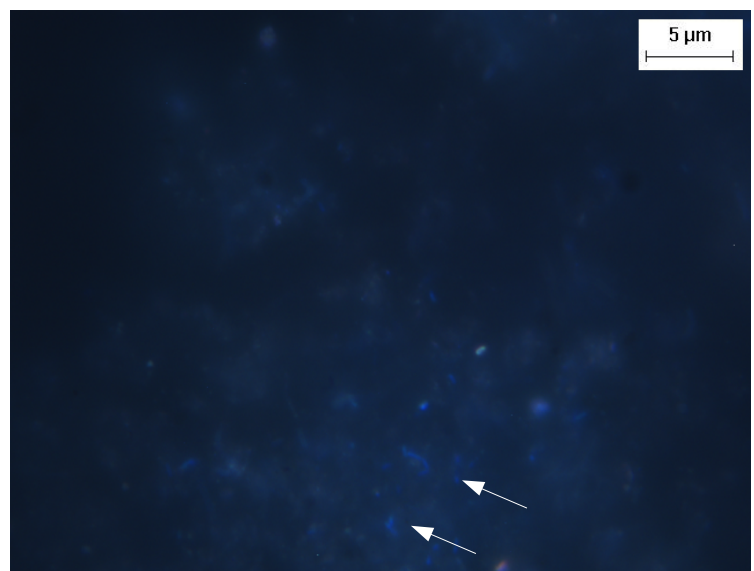

(b)

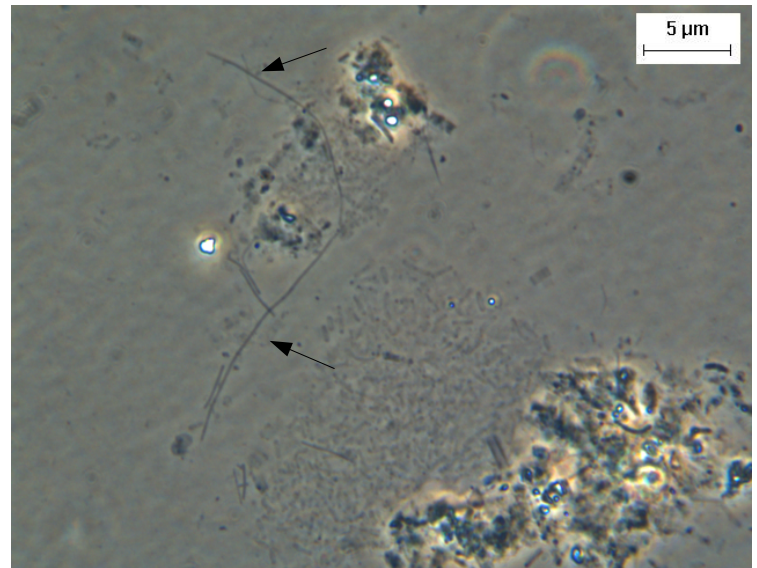

(d)

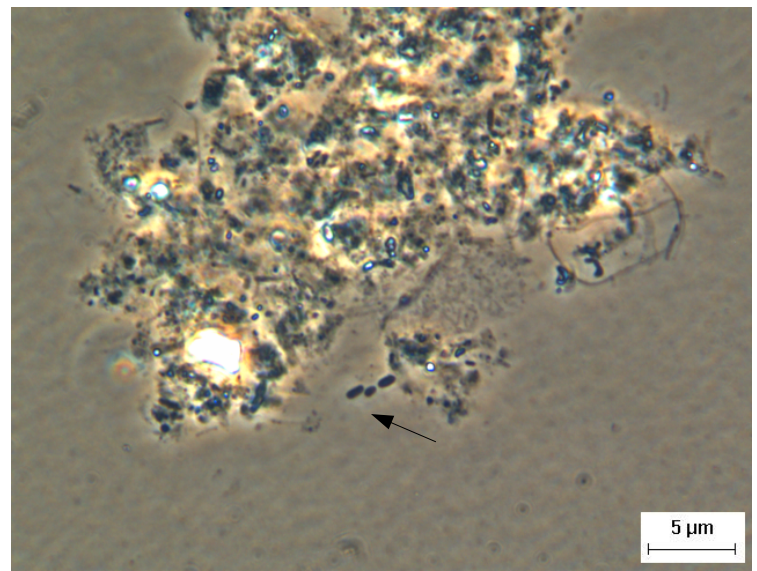

(f)

Figura 5.44. Observações morfológicas sob microscopia de contraste de fase e epifluorescência, referentes às amostras do reator sulfetogênico.

[Notação: (a) e (b) bacilos fluorescentes semelhantes às metanogênicas hidrogenotróficas; (c) e (d) bacilos delgados não fluorescentes; (e) bacilos curvos; (f) bacilos de formas arredondadas.] 


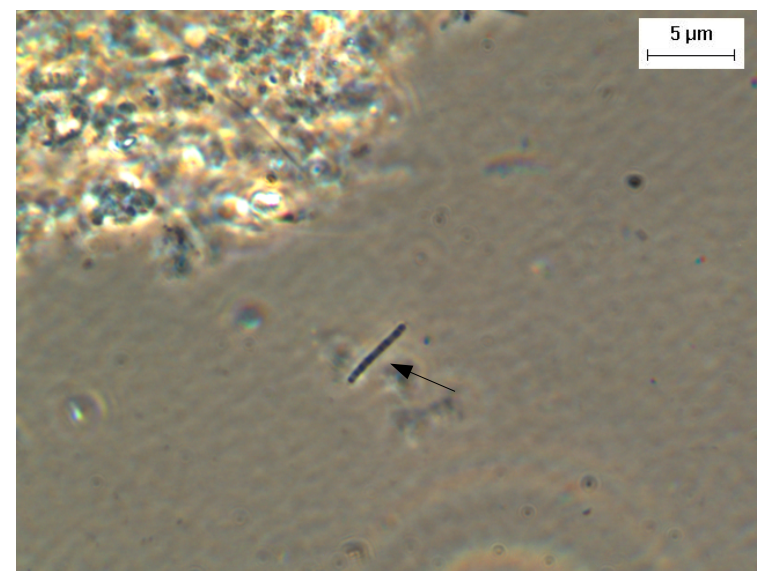

(a)

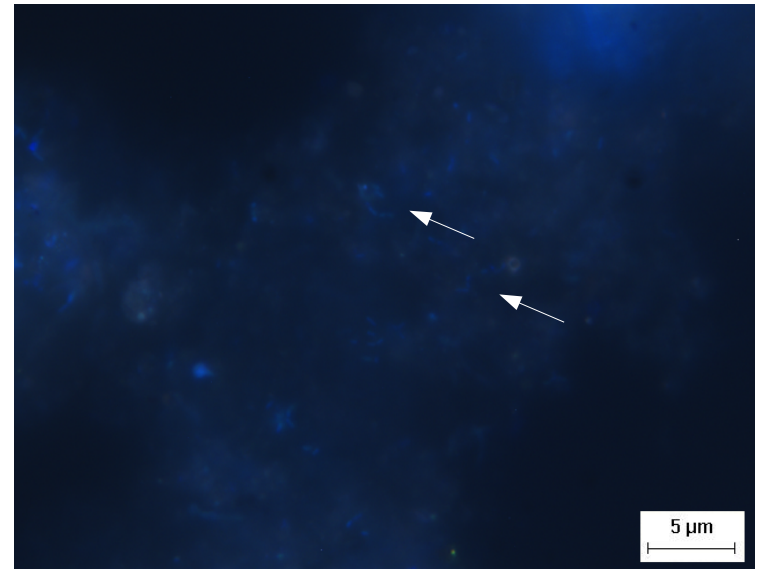

(c)

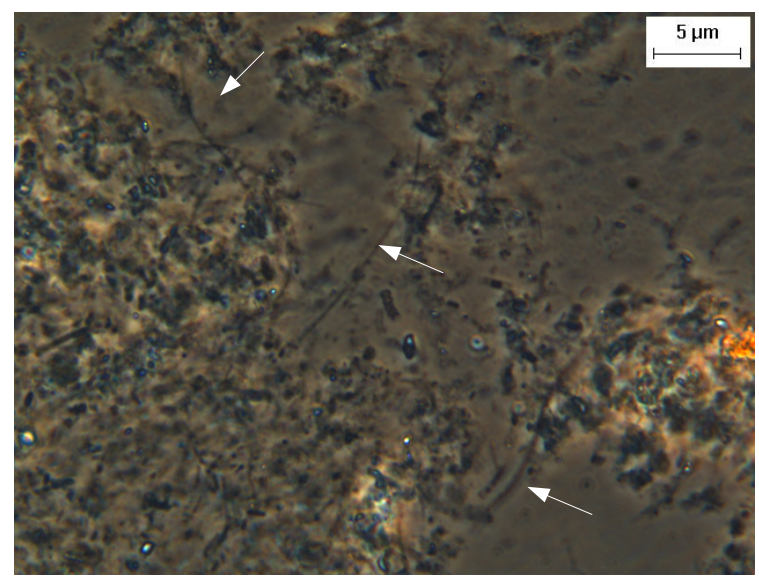

(e)

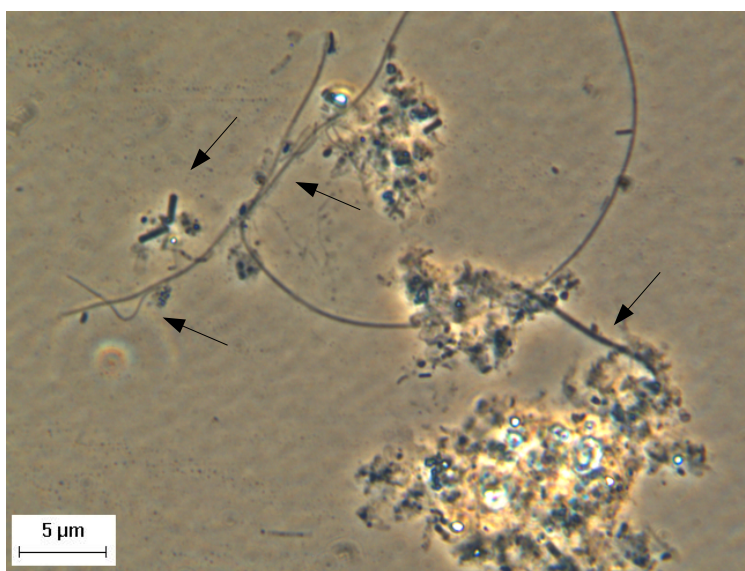

(b)

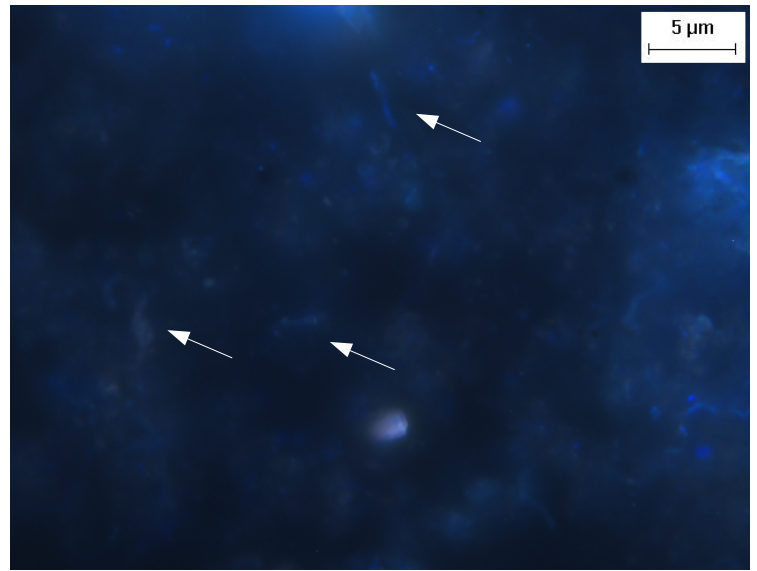

(d)

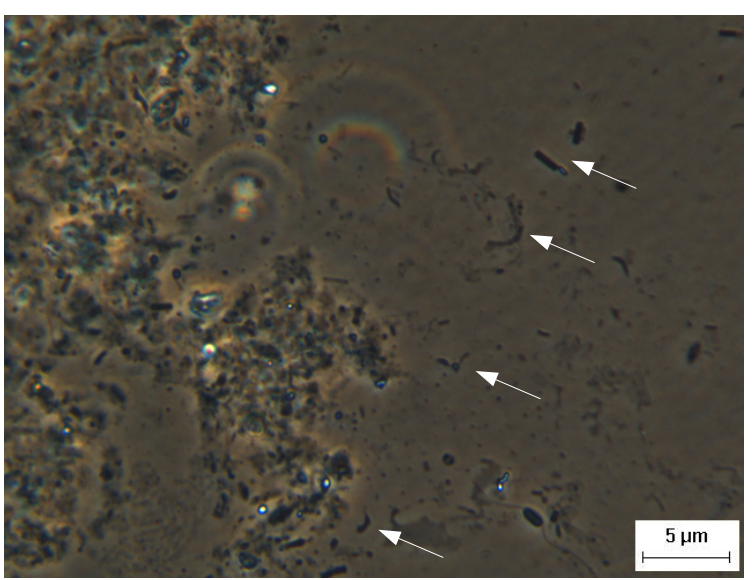

(f)

Figura 5.45. Observações morfológicas sob microscopia de contraste de fase e epifluorescência, referentes às amostras do reator desnitrificante.

[Notação: (a) filamento com inclusões; (b) bacilos arredondados, filamentos e bacilos delgados não fluorescentes; (c) e (d) bacilos fluorescentes semelhantes às metanogênicas hidrogenotróficas; (e) bacilos delgados não fluorescentes; (f) bacilos diversos e estreptococos.] 


\subsubsection{Análise da diversidade microbiana}

A caracterização qualitativa da comunidade microbiana foi realizada por meio da técnica de reação em cadeia da polimerase (PCR) seguida da eletroforese em gel de gradiente desnaturante (DGGE). Algumas bandas dos géis de DGGE foram selecionadas para realizar a identificação. As bandas indicadas nas Figuras 5.46 e 5.49 foram recortadas, eluídas e reamplificadas; posteriormente, foram seqüenciadas.

\subsubsection{DomínIo BACTERIA}

A Figura 5.46 revela o perfil de bandas de DGGE relacionadas ao Domínio Bacteria para o inóculo (A) e para os reatores metanogênico (B e C), sulfetogênico (D e E) e desnitrificante (F e G). Pôde-se observar que a adição de aldicarbe acarretou em mudanças significativas na população de microrganismos.

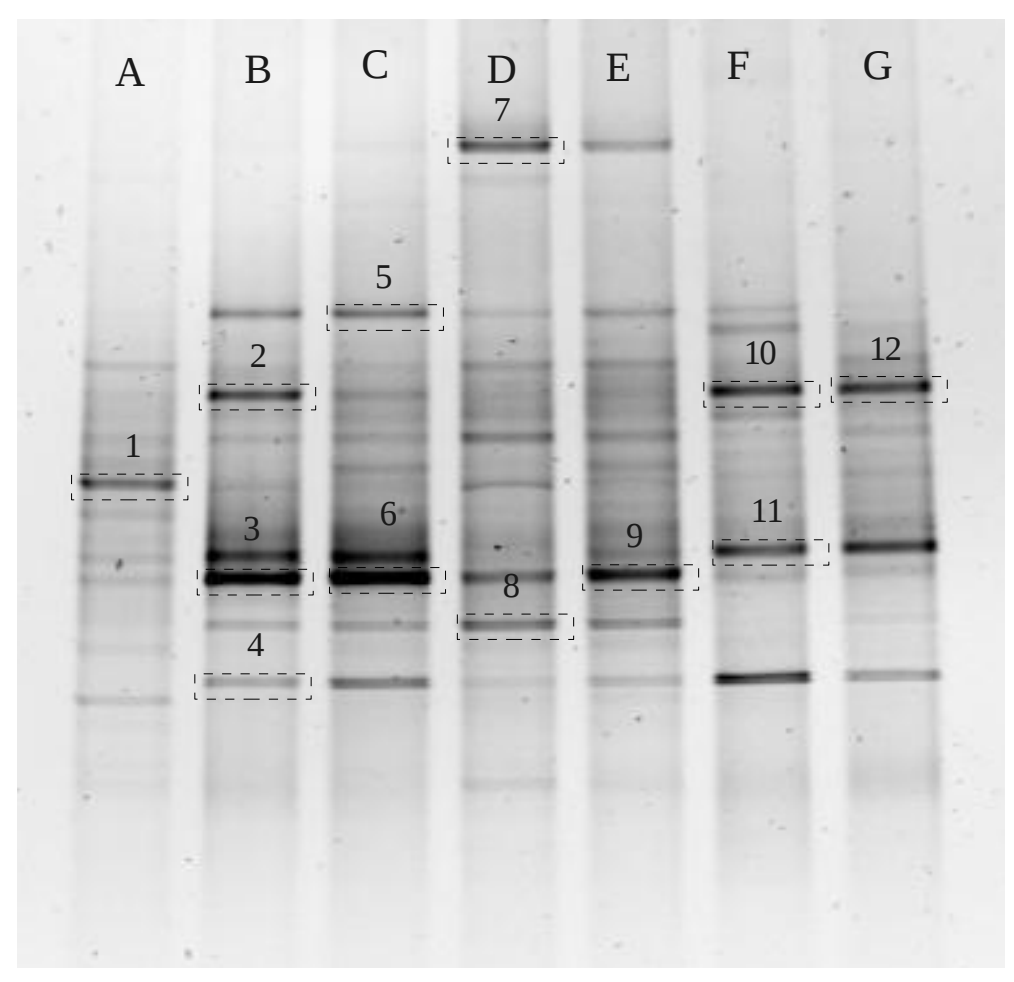

Figura 5.46. Perfil de bandas de DGGE usando primers para o Domínio Bacteria.

[Notação: A - Inóculo; B - Reator metanogênico após período de partida; C - Reator metanogênico ao final dos ensaios; D - Reator sulfetogênico após período de partida; E - Reator sulfetogênico ao final dos ensaios;

F - Reator desnitrificante após período de partida; G - Reator desnitrificante ao final dos ensaios]. 
O seqüenciamento das bandas revelou predomínio de microrganismos pertencentes ao filo Chloroflexi (Figura 5.47). Os resultados podem ser observados na Tabela 5.22.

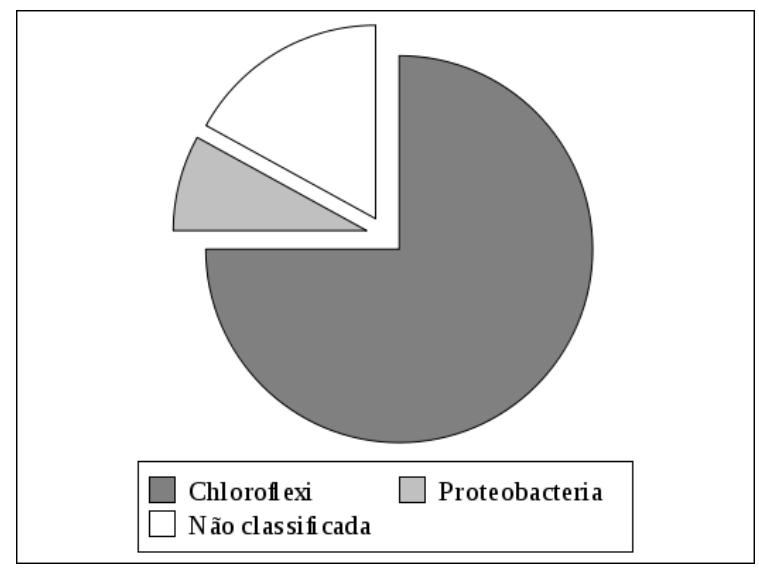

Figura 5.47. Diversidade de filos revelada pelo seqüenciamento das bandas de DGGE com relação ao Domínio Bactéria

Tabela 5.22. Identificação das bandas recortadas e seqüências do gel de DGGE com primers do Domínio Bacteria.

\begin{tabular}{|c|c|c|c|c|}
\hline Banda & Características & Número do acesso & $\begin{array}{c}\% \text { de } \\
\text { similaridade }\end{array}$ & Referência \\
\hline 1 & Bactéria não cultivada & EF602476 & 86 & $\begin{array}{c}\text { Elshahed et al. } \\
\text { (2007) }\end{array}$ \\
\hline $2,3,11$ e 12 & Chloroflexi & AY157139 & $88-91$ & Smith et al., 2003 \\
\hline 4 & $\begin{array}{c}\text { Bactéria do solo não } \\
\text { cultivada }\end{array}$ & AF423295 & 87 & $\begin{array}{l}\text { Valinsky et al } \\
\text { (2002) }\end{array}$ \\
\hline 5 & Bactéria não cultivada & DQ787689 & 93 & $\begin{array}{c}\text { Nelson et al } \\
\text { (2007) }\end{array}$ \\
\hline 6 e 10 & Cloroflexi & AY922075 & 90 & $\begin{array}{c}\text { Tringe et al } \\
\text { (2005) }\end{array}$ \\
\hline 7 & $\begin{array}{l}\text { Epsilon } \\
\text { proteobacterium }\end{array}$ & DQ295689 & 94 & $\begin{array}{l}\text { Engel et al., } \\
\text { submetido }\end{array}$ \\
\hline 8 & Bactéria não cultivada & EF208705 & 90 & Sorensen et al. \\
\hline 9 & Chlorobi bacterium & AJ519646 & 87 & Geissler et al \\
\hline
\end{tabular}

No reator operado sob condições metanogênicas, houve o favorecimento de microrganismos representados pelas bandas 2, 3, 4, 5 e 6. Dentre essas bandas, a número 5 foi 
a única a revelar microrganismos ainda não classificados. Por meio do seqüenciamento parcial do RNAr 16S, a banda 5 aproximou-se filogeneticamente (93\%) à seqüência depositada no Gene Bank DQ787689.

As bandas 2, 3, 4 e 6 aproximaram-se filogeneticamente a microrganismos do filo Chloroflexi. As bandas 2 e 3 tiveram 86\% de similaridade com a seqüência DQ787689, obtida em estudo de sistemas de lodos ativados tratando água residuária de indústria de papel e celulose. A banda 4, associada a AF423295 (87\%), e a banda 6, associada a AY922075 (90\%), foram similares com microrganismos da classe Anaerolineae.

As bandas 7, 8 e 9 representam microrganismos favorecidos no reator operado sob condições sulfetogênicas. A banda 7, presente somente no reator sulfetogênico, relacionou-se à seqüência DQ295689 (94\%), pertencente a microrganismo do gênero Sulfurovum, dentro do filo Proteobacteria. As bandas 8 e 9 relacionaram-se com EF208705 (90\%) e AJ519646 (87\%), respectivamente. Essas seqüências pertencem a microrganismos do filo Chloroflexi, classe Anaerolineae e família Caldilineacea.

As bandas 10, 11 e 12, favorecidas no reatores operado sob condições desnitrificantes, aproximaram-se filogeneticamente de microrganismos do filo Chloroflexi. A banda 10 foi relacionada com a seqüência AY922075 (90\%) pertencente à classe Anaerolineae.

A Figura 5.48 mostra a árvore filogenética obtida a partir da comparação das bandas de DGGE com seqüências do Gene Bank.

O filo Chloroflexi (bactérias verdes não sulfurosas) é representado por diversos clones de amostras ambientais e apenas poucas culturas representativas (Garrity e Holt, 2001). É dividido em quatro subfilos: I, II, III e IV (Hugenholtz et al., 1998). Os gêneros cultivados Chloroflexus, Oscillochloris, Herpetosiphon e Roseiflexus representam uma pequena porção do grupo afiliada ao subfilo III. O subfilo II contém apenas um microrganismo cultivado, denominado Dehalococcoides ethenogenes (Maymo-Gattel et al., 1997).

O subfilo I engloba a maior diversidade de amostras ambientais e contém clones de ambientes anaeróbios e anóxicos, como fontes termais, subsuperfície, lodo de sistemas de tratamento de águas residuárias. Clones de ambientes aeróbios foram retirados de amostras de aqüíferos contaminados e de sistemas de lodos ativados (Hugenholtz et al., 1998; Juretschko et al., 2002; Sekiguchi et al., 1999). 


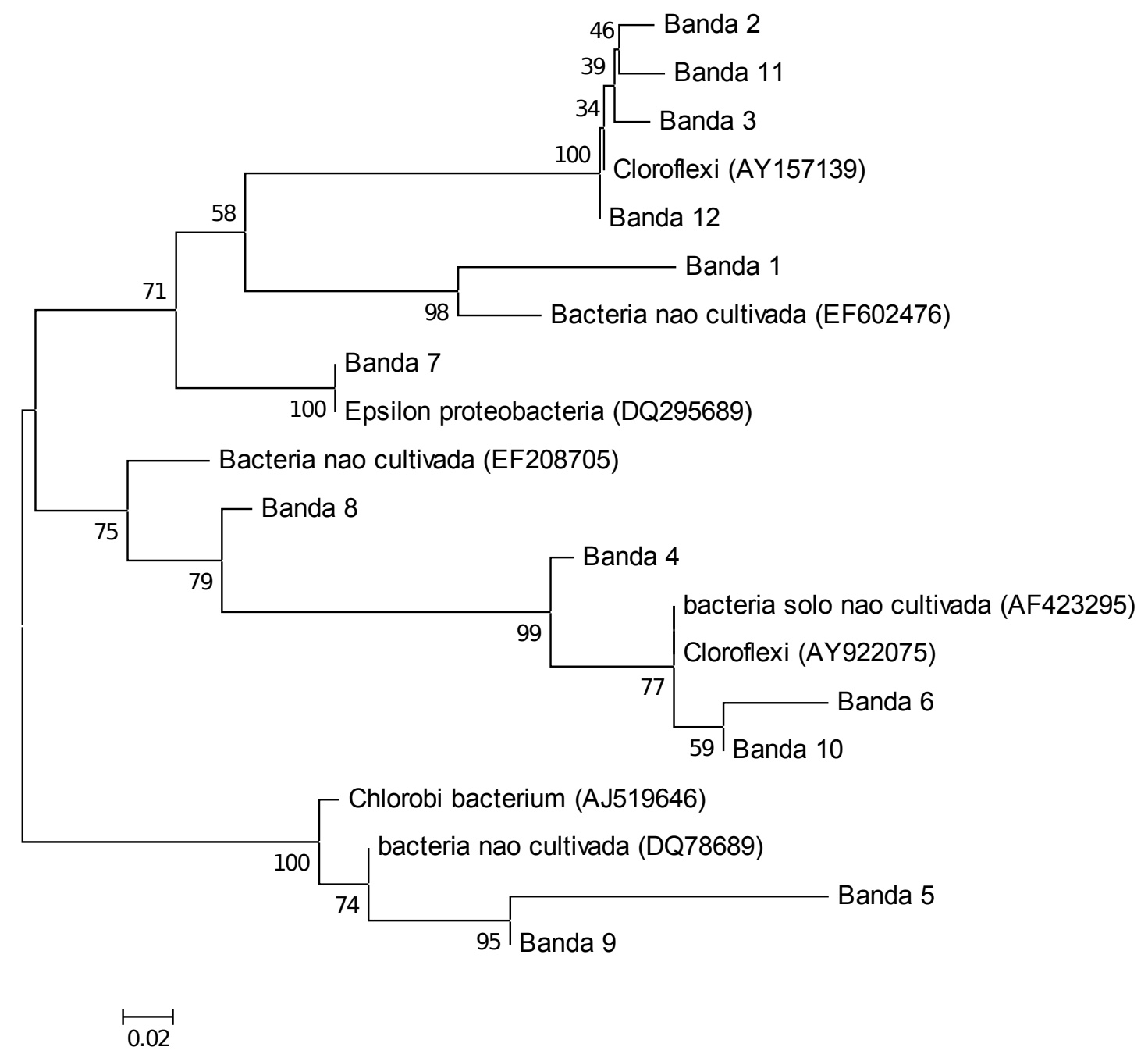

Figura 5.48. Árvore filogenética de consenso baseado nas seqüências de bandas recortadas do DGGE com primers para o Domínio Bacteria.

Obs.: Os valores presentes nos nós da arvore indicam as percentagens que o ramo se repetiu em 500 reamostragens (Bootstrap).

Evidências sugerem que membros do subfilo I desempenham funções importantes em seus ambientes, pois são numericamente abundantes. Em sistemas de lodo granular anaeróbio termofílico e mesofílico, eles contribuem para a manutenção da estrutura do lodo (Sekiguchi et al., 1999).

A granulação do lodo é um fenômeno comum em reatores UASB. Dentre os vários grupos de microrganismos que contribuem para a estrutura dos grânulos (como as espécies de Methanosaeta, do Domínio Archaea), as bactérias filamentosas afiliadas ao subfilo I de Chloroflexi foram recentemente reconhecidas como o grupo microbiano que afeta diretamente a granulação e o intumescimento do lodo de reatores UASB sob condições termofílicas. 
Muita atenção ainda deve ser despendida para os microrganismos englobados no subfilo I de Chloroflexi. A fisiologia, a ecologia e a função in situ dessas bactérias ainda são desconhecidas, principalmente em reatores sob condições mesofílicas, pois os clones são totalmente identificados a partir de amostras ambientais e o isolamento das espécies não foi conseguido.

As populações encontradas em reatores mesofílicos apresentam as mesmas características daquelas encontradas em reatores termofílicos, mas são menos abundantes. Isto pode ser um indicativo de que elas não são tão essenciais na formação dos grânulos mesofílicos. Chloroflexi pertencentes ao subfilo I foram encontradas em reatores mesofílicos usados no tratamento de tereftalato e metilbenzoato. Também foram encontradas em reatores de leito fluidizado tratando água residuária rica em etanol e sulfato, lactato e sulfato, triclorobenzeno e de destilaria de vinho (Yamada et al., 2005).

A classe Anaerolinea, pertencente ao subfilo I de Chloroflexi, é formada por microrganismos estritamente anaeróbios, gram negativos, sésseis, filamentosos e não formadores de esporos. Anaerolineae tem sido considerada há tempos, uma classe de micróbios que ainda serão cultivados, pois são recalcitrantes para o cultivo e isolamento (Sekiguchi et al., 2001). Recentemente, o primeiro microrganismo tangível da classe foi isolado de reator UASB em condições termofílicas e nomeado Anaerolinea thermophila (Sekiguchi et al., 2001; Sekiguchi et al., 2003). Três estirpes filamentosas pertencentes à classe (Anaerolinea thermolimosa, Levilinea saccharolytica e Leptolinea tardivitalis) foram, posteriormente, isoladas e caracterizadas (Yamada et al., 2005; 2006). Até o momento, estas quatro estirpes são os únicos organismos conhecidos capazes de serem cultivados e completamente descritos na classe Anaerolineae.

Dentro da classe Anaerolinea, a família Caldilineaceae é representada por microorganismos aeróbios e anaeróbios, gram negativos, sésseis, filamentosos e não formadores de esporos. O primeiro organismo cultivável foi obtido a partir de fontes termais sulfurosas do Japão e nomeado Caldilinea aerophila (Sekiguchi et al., 2003).

O gênero Sulfurovum, pertencente ao filo Proteobacteria, é composto por microrganismos mesofílicos, anaeróbios facultativos, gram negativos, cocóides ou pequenos bacilos. Seu crescimento pode ocorrer com enxofre elementar ou tiosulfato como doadores de elétrons. A espécie tipo, Sulfurovum lithotrophicum, foi isolada de sedimentos hidrotermais profundos em Okinawa, Japão (Inagaki et al., 2004). 


\subsubsection{DomínIO ARCHAEA}

A Figura 5.49 revela o perfil de bandas de DGGE relacionadas ao Domínio Archaea para o inóculo (A) e para os reatores metanogênico (B e C), sulfetogênico (D e E) e desnitrificante (F e G). Pôde-se observar que a adição de aldicarbe não acarretou em mudanças significativas na população de microrganismos. A Tabela 5.23 mostra as seqüências associadas às bandas e a Figura 5.50 mostra a árvore filogenética obtida a partir da comparação das bandas de DGGE com seqüências do Gene Bank.

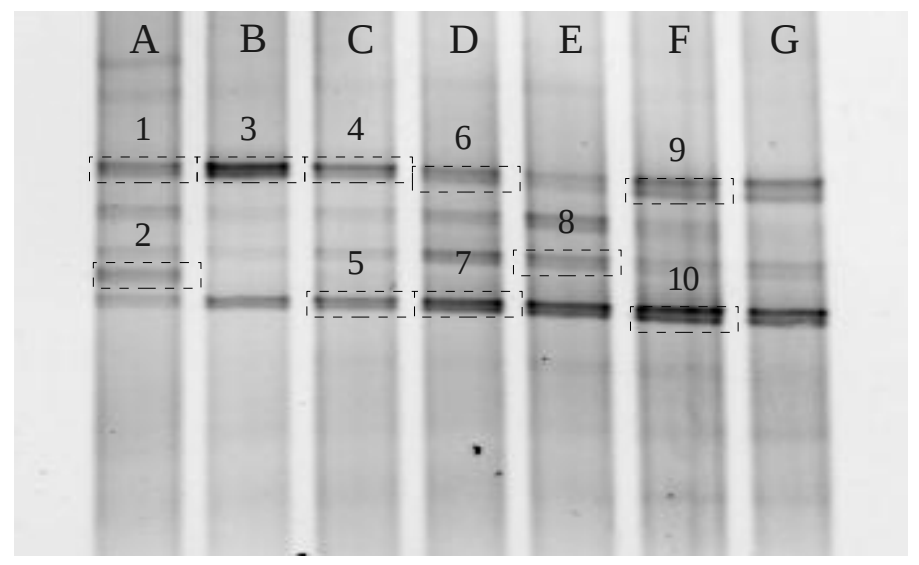

Figura 5.49. Perfil de bandas de DGGE usando primers para o Domínio Archaea.

[Notação: A - Inóculo; B - Reator metanogênico após período de partida; C - Reator metanogênico ao final dos ensaios; D - Reator sulfetogênico após período de partida; E - Reator sulfetogênico ao final dos ensaios;

F - Reator desnitrificante após período de partida; G - Reator desnitrificante ao final dos ensaios].

Tabela 5.23. Identificação das bandas recordadas e seqüências do gel de DGGE com primers do Domínio Archaea.

\begin{tabular}{ccccc}
\hline Banda & Características & Número do acesso & $\begin{array}{c}\text { \% de } \\
\text { similaridade }\end{array}$ & Referência \\
\hline 1, 3, 4, 6 e 9 & $\begin{array}{c}\text { Methanosaeta } \\
\text { Consórcio }\end{array}$ & AY454759 & 99 & Piza et al \\
2 & metanogênico & AF423187 & 98 & Ficker et al. \\
& degradador de tolueno & & & (1999) \\
5,7 & Methanosaeta & AY692058 & 98 & Fernandez et al. \\
8 & Methanosaeta & AB288619 & 97 & Ishii et al. \\
10 & Methanobacterium & AY8/99832 & 94 & Kovacik et al. \\
\hline
\end{tabular}




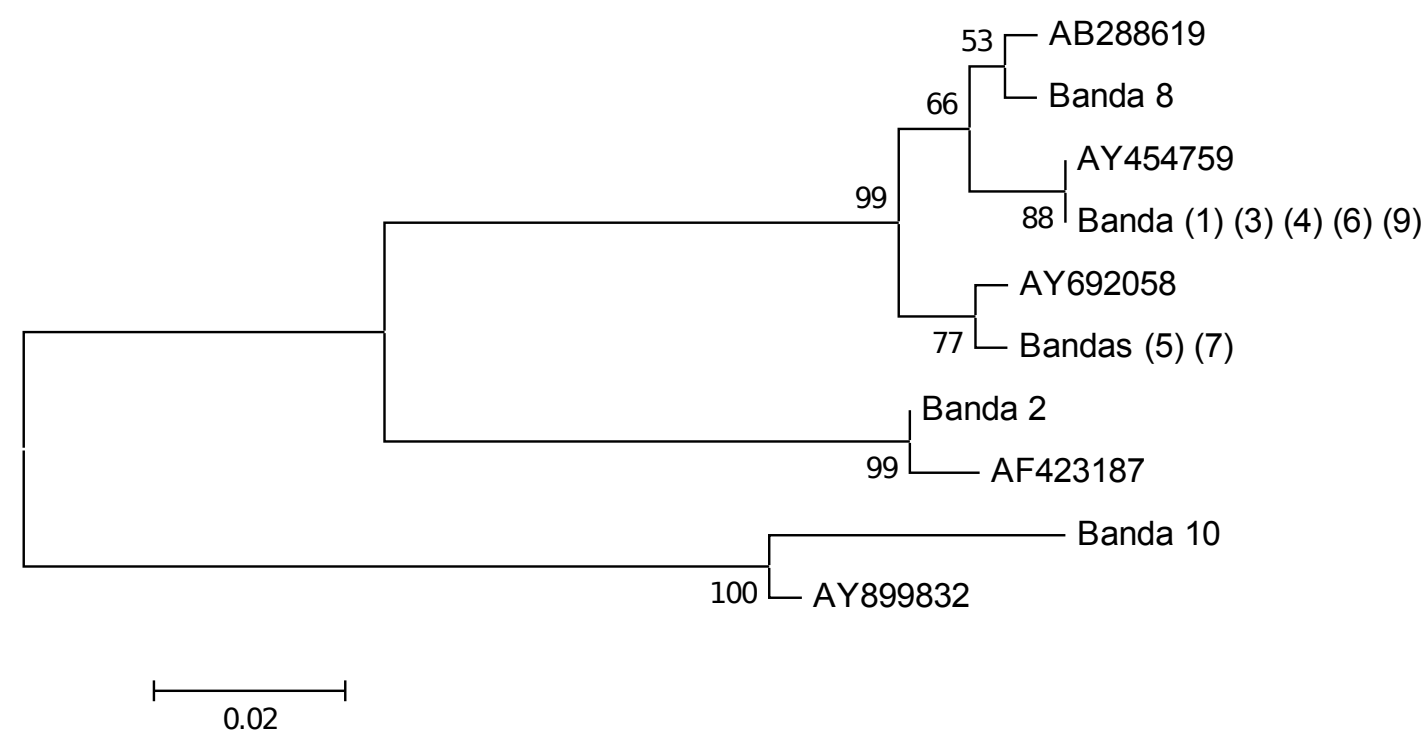

Figura 5.50. Árvore filogenética de consenso baseado nas seqüências de bandas recortadas do DGGE com primers para o Domínio Archaea.

Obs.: Os valores presentes nos nós da arvore indicam as percentagens que o ramo se repetiu em 500 reamostragens (Bootstrap).

No reator operado sob condições metanogênicas, houve o favorecimento de microrganismos representados pelas bandas 3,4 e 5 . Todas aproximaram-se filogeneticamente (98-99\%) a seqüências depositada no Gene Bank relacionadas a Methanosaeta.

As bandas 6 e 7 representam microrganismos favorecidos no reator operado sob condições sulfetogênicas, também relacionadas a Methanosaeta.

As bandas 8, 9 e 10, favorecidas no reatores operado sob condições desnitrificantes, aproximaram-se filogeneticamente de microrganismos relacionadas a Methanosaeta e a Methanobacterium.

Microrganismos pertencentes à Ordem Methanosarcinales catalisam a etapa final da degradação da matéria orgânica em ambientes anaeróbios, onde a luz e aceptores finais de elétrons diferentes do CO2 são limitados. Representantes desse grupo são cosmopolitas em ambientes anaeróbios, sendo encontrados em água corrente, lama e sedimento marinhos, rúmen de ungulados, lagoas de dejetos animais, lodo de reatores de digestão anaeróbia e fezes de animais. Seqüências genéticas do RNAr 16S que aparentemente pertencem a organismos da Ordem Methanosarcinales foram detectadas em águas presentes nas fissuras de minas de ouro da África do Sul (TAKAI et al., 2001), encanamentos de gás industriais (ZHU et al., 2003) e na cavidade periodontal humana (ROBICHAUZ et al., 2003). 
Quanto à morfologia, membros dessa Ordem podem ser cocóides, pseudosarcinas ou bacilos embainhados. A maioria das células possui parede celular protéica, algumas vezes envolta por bainha ou heteropolissacarídeo. Na parede celular não há presença de peptideoglicana ou pseudomureína. As células são estritamente anaeróbias, e obtêm energia com a concomitante produção de metano. Os organismos da Ordem Methanosarcinales são capazes de utilizar vasta gama de substratos orgânicos para a metanogênese, podendo percorrer as vias hidrogenotrófica, metilotrófica e acetoclástica de degradação. Todavia, algumas espécies podem usar apenas uma das vias metabólicas, enquanto outras utilizam as três vias. A Ordem Methanosarcinales compreende duas Famílias, Methanosarcinaceae e Methanosaetaceae.

A família Methanosaetaceae inclui um gênero, Methanosaeta. Todas as células utilizam o acetato como única fonte de carbono. O gênero Methanosaeta é representado por duas espécies, Methanosaeta concilii e Methanosaeta thermophila, que metabolizam o acetato em metano e $\mathrm{CO}_{2}$. Originalmente, estes organismos foram classificados como pertencentes ao gênero Methanothrix. Como a cultura que validou a espécie não era pura, a mesma foi considerada ilegítima. Cultura axênica de bacilos embainhados, acetoclásticos, mesofílicos e metanogênicos foi descrita por Patel (PATEL, 1984; PATEL, 1985) como Methanothrix concilli e posteriormente transferida para o novo gênero Methanosaeta.

A presença de Methanosaeta $s p$. nos reatores pode ser explicada pela presença de actetato no lodo usado como inóculo e posteriormente pela endogenia das células. Como a espécie possui baixo Ks para crescimento em acetato, por volta de 0,47mM, (GONZALESGIL et al., 2001), é possível que a espécie tenha se desenvolvido a partir do acetato residual do lodo e da atividade endógena dos microrganismos. 


\section{CONCLUSÕES}

- O método desenvolvido de detecção e quantificação do aldicarbe por cromatografia líquida de alta eficiência (HPLC) foi adequado aos objetivos do trabalho.

- O reator anaeróbio horizontal de leito fixo (RAHLF) demonstrou potencial de emprego como tecnologia de remoção de aldicarbe como fonte única de carbono em diferentes níveis de oxidação (metanogênico, sulfetogênico e desnitrificante) e diferentes concentrações.

- Nas concentrações de 5 e 10 mg. $\mathrm{L}^{-1}$, em todos níveis de oxidação avaliados, foram obtidas elevadas eficiências de remoção (superiores a 83,0\%). O aumento da concentração de aldicarbe causou redução na eficiência de conversão a partir de $10 \mathrm{mg} . \mathrm{L}^{-1} \mathrm{em}$ todos reatores avaliados.

- Em condições metanogênicas, a resistência à transferência de massa externa e interna não exerceu efeito significativo. Assim, velocidade global de reação do sistema foi limitada somente pela reação bioquímica da degradação do aldicarbe. O coeficiente de primeira ordem $\mathrm{k}_{1}$ foi de $1,46 \pm 0,09 \cdot 10^{-5} \cdot \mathrm{L} \cdot \mathrm{mgSVT}^{-1} \cdot \mathrm{h}^{-1}$.

- O microrganismo constatado em maior número de bandas para o Domínio Bacteria foi da Classe Chlorofexi enquanto que para o Domínio Archaea foi a Methanosaeta. 


\section{SUGESTÕES}

- Desenvolver metodologia de detecção e quantificação de metabólitos da degradação anaeróbia do aldicarbe por meio de espectrofotometria de massas.

- Avaliar o efeito do co-metabolismo (por meio da adição de substratos orgânicos alternativos) na degradação anaeróbia de aldicarbe.

- Avaliar a possibilidade de degradação do aldicarbe em reator anaeróbio operado em bateladas seqüenciais com biomassa imobilizada (ASBR) mediante a variação de seus parâmetros de operação (tempo de enchimento, razão volume tratado/volume total, por exemplo).

- Determinar o efeito da concentração inicial de biomassa e de outros fatores na concentração residual de substrato em sistemas anaeróbios.

- Determinar parâmetros cinéticos de degradação do aldicarbe em condições sulfetogênicas em diferentes concentrações. 


\section{REFERÊNCIAS BIBLIOGRÁFICAS}

ANDRAWES, N.R.; BAGLEY, W.P.; HERRETT, R.A. Fate and carryover properties of Temik aldicarb pesticide [2-methyl-2-(methylthio)propionaldehyde O(methylcarbamoyl)oxime] in soil. Journal of Agricultural and Food Chemistry, v.19(4), p.727-730, 1971.

ANDREWS, J.F. A mathematical model for the continuous culture of microrganisms utilizing inhibitory substrate. Biotechnology and Bioengineering, v.10, p.707-723, 1992.

ANGELIDAKI, I.; PETERSEN, S. P.; AHRING, B. K. Effects of lipids on thermophilic anaerobic digestion and reduction of lipid inhibition upon addition of bentonite. Applied Microbiology Biotechnology, v.33, p.469-472, 1990.

APHA, American Public Health Association, American Water Works Association, Water Environment Federation. Standard methods for examination of water and wastewater. $20^{\text {th }}$ ed., Washington D. C.: American Public Health Association, 1999. 1325p.

ARRÁEZ-ROMÁN， D.; SEGURA-CARRETERO， A.; CRUCES-BLANCO， C.; FERNÁNDEZ-GUTIÉRREZ A. Determination of aldicarb, carbofuran and some of their main metabolites in groundwater by application of micellar electrokinetic capillary chromatography with diode-array detection and solid-phase extraction. Pest management science, v.60(7), p.675-679, 2004.

ASGARI, N.; SHARIF, F.A.; ÖZDEN, M.Y.; ALAEDDINOĞLU, N.G. Bacterial utilization of purified Temik. Process Biochemistry, v.30(2), p.183-187, 1995.

ASCE/WEF, American Society of Civil Engineers/Water Environment Federation. Design of municipal wastewater treatment plants. $2^{\text {nd }}$ ed., New York: American Society of Civil Engineers/Water Environment Federation, 1992. 1592p.

BARBOSA, T. M. L.; RIGITANO, R. L. O. Influência da classe e profundidade do solo na 
degradação do inseticida-nematicida aldicarbe. Pesquisa Agropecuária Brasileira, v.29(6), p.955-960, 1994.

BARON, R.L.; MERRIAM, T.L. Toxicology of aldicarb. Reviews of Environmental Contamination and Toxicology, v.105, p.1-70, 1988.

BRASIL. Conselho Nacional do Meio Ambiente. Resolução nº 20, de 18 de junho de 1986. Estabelece a classificação das águas, doces, salobras e salinas no Território Nacional, Brasília, Diário Oficial da União, jun., 1986.

BRASIL. Lei $\mathrm{n}^{\circ}$ 7.802, de 11 de julho de 1989. Dispõe sobre a pesquisa, a experimentação, a produção, a embalagem e rotulagem, o transporte, 0 armazenamento, a comercialização, a propaganda comercial, a utilização, a importação e exportação, o destino final dos resíduos e embalagens, o registro, a classificação, o controle, a inspeção e a fiscalização de agrotóxicos, seus componentes e afins, e dá outras providências, Brasília, Diário Oficial da União, jun., 1989.

BRASIL. Decreto $n^{\circ}$ 98.816, de 11 de janeiro de 1990. Regulamenta a Lei $\mathbf{N}^{\mathbf{0}} \mathbf{7 . 8 0 2}$, de 11 de julho de 1989, Brasília, Diário Oficial da União, jun., 1990.

BRASIL. Decreto $n^{\circ}$ 4.074, de 4 de janeiro de 2002. Regulamenta a Lei $\mathbf{N}^{\mathbf{0}} \mathbf{7 . 8 0 2}$, de 11 de julho de 1989, Brasília, Diário Oficial da União, jun., 2002.

BRASIL. Agência Nacional de Vigilância Sanitária. Resolução nº 899, de 29 de maio de 2003. Guia para validação de métodos analíticos e bioanalíticos, Brasília, Diário Oficial da União, jun., 2003.

BRASIL. Conselho Nacional do Meio Ambiente. Resolução nº 357, de 17 de março de 2005. Dispõe sobre a classificação dos corpos de água e diretrizes ambientais para o seu enquadramento, bem como estabelece as condições e padrões de lançamento de efluentes, e dá outras providências, Brasília, Diário Oficial da União, mar., 2005.

BRASIL. Conselho Nacional do Meio Ambiente. Resolução Nº 396, de 3 de abril de 2008. Dispõe sobre a classificação e diretrizes ambientais para o enquadramento das águas 
subterrâneas e dá outras providências, Brasília, Diário Oficial da União, abr., 2008.

BRINGI, V.; DALE, B. E. Experimental and theorical evidence for convective nutrient transport in an immobilized cell suport. Biotechnology Progress, v.6(3), p.205-209, 1990.

BRUCHA, G.; DAMIANOVIC, M. H. R. Z.; SAIA, F. T.; DAMASCENO, L. H. S.; VAZOLLER, R. F. Mechanisms for removing pentachlorophenol present in synthetic wastewater in anaerobic fixed bed reactors. In: LATIN AMERICAN WORKSHOP AND SYMPOSIUM ON ANAEROBIC DIGESTION, 8., 2005, Punta del Este. Proceedings... Punta del Este: IWA, 2005. p. 561.

CANNA, S.; PIERA, P. Integrating biological into chemical approach in evaluating water pollution-microtox response to N-methyl carbamates. In: INTERNATIONAL CONGRESS ON PESTICIDE CHEMISTRY, 8., 1994, Washington DC. Abstracts... Washington DC: 1994. p.44.

CHUI, Q.S.H. Uncertainties related to linear calibration curves: a case study for flame atomic absorption spectrometry. Journal of the Brazilian Chemical Society, v.18(2), p.424-430, 2007.

CHUI, Q.S.H.; ZUCHINI, R. LICHTIG, J. Qualidade de medições em química analítica. Estudo de caso: determinação de cádmio por espectrofotometria de absorção atômica com chama. Química Nova, v. 24(3), p. 374-380, 2001.

COHEN, S.Z., EIDEN, C., \& LORBER, M.B. Monitoring groundwater for pesticides. In: Garner, W.Y., ed. Evaluation of pesticides in groundwater, Washington, DC, American Chemical Society, pp. 170-196 (ACS Symposium Series 315), 1986.

COX, C. Aldicarb. Journal of Pesticide Reform, v.12(2), p.31-35, 1992.

DAMASCENO, L.H.S. Tratamento de soro de queijo no ASBR: influência da estratégia de alimentação. 2004. 218 f. Dissertação (Mestrado em Hidráulica e Saneamento) - Escola de Engenharia de São Carlos, Universidade de São Paulo, São Carlos, 2004. 
DAMASCENO, L.H.S.; ADORNO, M.A.T.; HIRASAWA, J.S.; VARESCHE, M.B.A.; ZAIAT, M. Development and validation of a HPLC method for the determination of aldicarb, aldicarb sulfoxide and aldicarb sulfone in liquid samples from anaerobic reactors. Journal of Brazilian Chemical Society, v.19, p.1158-1164, 2008.

DANCKWERTS, P.V. Continuous flow systems - distribution of residence times. Chemical Engineering Science, v. 2, p.1-13, 1953.

DE HAAN, F.A.M. Effects of agricultural practices on the physical, chemical and biological properties of soils: Part III. Chemical degradation of soil as the results of the use of mineral fertilizers and pesticides: Aspects of soil quality evaluation. Netherlands Journal for Agricultural Science, v.36, p.211-235, 1988.

DE NARDI, I. R. Degradação de benzeno, tolueno, etilbenzeno e xilenos (BTEX) em reator anaeróbio horizontal de leito fixo (RAHLF). 2002. 171 f. Tese (Doutorado em Hidráulica e Saneamento) - Escola de Engenharia de São Carlos, Universidade de São Paulo, São Carlos, 2002.

DE NARDI, I.R.; ZAIAT, M.; FORESTI, E. Influence of the tracer characteristics on hydrodynamic models of packed-bed bioreactors. Bioprocess Engineering, v.21, p.469-476, 1999.

DI CORCIA, A.; NAZZARI, M.; RAO, R.; SAMPERI, R. SEBASTIANI, E. Simultaneous determination of acidic and non-acidic pesticides in natural waters by liquid chromatographymass spectrometry. Journal of chromatography. A, v.878(1), p.87-98.

DILALLO, R; ALBERTSON, O.E. Volatile Acids by Direct Titration. Journal of Water Pollution Control Federation, v.33, n.4, p.356-365, 1961.

DINARDO-MIRANDA, L.L. Aldicarbe em cana-de-açúcar. Brasília: Câmara dos Deputados, 2007. Audiência pública para discussão do Projeto de Lei $n^{0}$ 7.586/06, do Deputado Fernando Coruja, que acrescenta inciso ao $\S 6^{\circ}$ do Art. $3^{\circ}$ da Lei $n^{\circ} 7.802$, de 11 de julho de 1989, proibindo a comercialização do aldicarbe, conhecido como "chumbinho", e o PL 625/07, apensado. Disponível em: <http://www2.camara.gov.br/internet/comissoes/ 
capadr/audiencias-2007/rap301007leila.pdf>. Acesso em: 01 jan. 2008.

DUARTE, I.C.S. Caracterização microbiológica da remoção e degradação de alquilbenzeno linear sulfonado (LAS) em reatores anaeróbios com biofilme e células planctônicas. 2006. 223 f. Tese (Doutorado em Hidráulica e Saneamento) - Escola de Engenharia de São Carlos, Universidade de São Paulo, São Carlos, 2006.

DUARTE, I.C.S.; OLIVEIRA, L.L.; BUZZINI, A.P.; ADORNO, M.A.T.; VARESCHE, M.B.A. Development of a method by HPLC to determine LAS and its application in anaerobic reactors. Journal of Brazilian Chemical Society, v.17 (7), p.1360-1367, 2006.

ELESPURU, R.; LIJNSKY, W.; SETLOW, J.K. Nitrosocarbaryl as a potent mutagen on environmental significance. Nature, v.247, p.386-387, 1974.

ELSHAHED, M.S.; YOUSSEF, N.H.; LUO, Q.; NAJAR, F.Z.; ROE, B.A.; SISK, T.M.; BUHRING, S.I.; HINRICHS, K.U.; KRUMHOLZ, L.R. Phylogenetic and metabolic diversity of planctomycetes from anaerobic, sulfide- and sulfur-rich zodletone spring, Oklahoma. Applied Environmental Microbiology, v.73(15), p.4707-4716, 2007.

ENGEL, A.S.; PORTER, M.L. Geographic diversity of novel evolutionary lineages within the epsilon proteobacteria from terrestrial sulfidic springs and caves. Não publicado.

FAZOLO, A. Determinação de parâmetros cinéticos e de transferência de massa em reator radial aeróbio-anóxico alimentado com esgoto sanitário tratado em reator anaeróbio. 2003. 185 f. Tese (Doutorado em Hidráulica e Saneamento) - Escola de Engenharia de São Carlos, Universidade de São Paulo, São Carlos, 2003.

FERNANDEZ, N.; DIAZ, E.E.; AMILS, R.; SANZ, J.L. Molecular ecology of anaerobic biofilms. Não publicado.

FICKER, M.; KRASTEL, K.; ORLICKY, S.; EDWARDS, E. Molecular characterization of a toluene-degrading methanogenic consortium. Applied Environmental Microbiology, v.65(12), p.5576-5585, 1999. 
GEISSLER, A.; TZVETKOVA, T.; FLEMMING, K.; SELENSKA-POBELL, S. Comparison of natural bacterial communities found in uranium mining waste piles and mill tailings. Não publicado.

GIRALDO-GOMEZ, E.; GOODWIN, S.; SWITZENBAUM, M. S. Influence of mass transfer limitations on determination of the half saturation constant for hydrogen uptake in a mixed culture methane producing enrichment. Biotechnology and Bioengineering, v.40, p.768-776, 1992.

GRIFFITHS, R.I.; WHITELEY, A.S.; O’DONNELL, A.G.; BAILEY, M.J. Rapid method for coextraction of DNA and RNA from natural environments for analysis of ribosomal DNA and rRNA-based microbial community composition. Applied Environmental Microbiology, v.66 (12), p.5488-5491, 2000.

HIEBSCH, S. The occurrence of 35 pesticides in Canadian drinking water and surface water. Environmental Health Directorate, Department of National Health and Welfare. Ottawa: 1988.

HIPPE, H.; CASPARI, D.; FIEBIG, K.; GOTTSCHALK, G. Utilization of trimethylamine and other $\mathrm{N}$-methyl compounds for growth and methane formation by Methanosarcina barkeri. Proceedings of the National Academy of Sciences, v.76, p.494-498, 1979.

ISHII, S.; HOTTA, Y.; WATANABE, K. Characterization of competitive electron flow between electricity generation and methane formation in microbial fuel cell. Não publicado.

JACKSON, R.E.; MUTCH, J.P.; PRIDDLE, M.W. Persistence of aldicarb residues in the sandstone aquifer of Prince Edward Island, Canada. Journal of Contaminant Hydrology, v.6, p.21-35, 1990.

JANDIK, P.; BONN, G. Capillary electrophoresis of small molecules and ions, VCH Publishers: New York, 1993.

JONES, R.L.; ESTES, T.L. Summary of aldicarb monitoring and research programs in the USA. Journal of Contaminant Hydrology, v.18, p.107-140, 1995. 
KAZUMI, J.; CAPONE, D. G. Microbial aldicarb transformation in aquifer, lake and salt marsh sediments. Applied and Environmental Microbiology, v.61(8), p.2820-2829, 1995.

KIENE, R.P.; CAPONE, D.G. Stimulation of methanogenesis by aldicarb and several other N-methyl carbamates pesticides. Applied and Environmental Microbiology, v.51(6), p.1247-1251, 1986.

KING, G.M.; KLUG, M.J.; LOVLEY, D.R. Metabolism of acetate, methanol and methylated amines in sediments of Lowes Cove, Maine. Applied and Environmental Microbiology, v.45, p.1848-1850, 1983.

KÖK, F.N.; ARICA, M.Y.; HALİCİGIL, C.; ALAEDDINOĞLU, N.G.; HASİRCİ, V. Biodegradation of aldicarb in a packed-bed reactor by immobilized Methylosinus. Enzime and Microbial Technology, v.24, p.291-296, 1999.

KOVACIK JR,W.P.; SCHOLTEN, J.C.M.; ZHANG, W.; CULLEY, D.; HICKEY, R.; BROCKMAN, F.J. Changes in 16S rRNA, mcrA, and dsrAB gene diversity in UASB bioreactor granules in response to short-term changes in substrate feed.

KRAMERS, H.; ALBERDA, G. Frequency response analysis of continuos flow systems. Chemical Engineering Science, v. 2, p.173-181, 1953.

KUDO, Y.; NAKAJIMA, T.; MIYAKI, T.; OYAIZU, H. Methanogen flora of paddy soils in Japan. FEMS Microbiology Ecology, v.22(1), p.39-48, 1997.

LEE, P.W. Handbook or residue analytical methods for agrochemicals. John Wiley \& Sons. Vol. 1, 2003, 1552p.

LENS, P. N. L.; VISSER, A.; JANSEN, A. J. H.; HULSHOFF POL, L. W.; LETTINGA, G. Biotechnological treatment of sulfate-rich wastewaters. Critical Reviews in Environmental Science and Techonology, v.28(1), p.41-88, 1988.

LEVENSPIEL, O. Chemical reaction engineering. $3^{\text {a }}$ ed. John Wiley \& Sons, 1998, 688p. 
LORBER, M. N.; COHEN, S. Z.; NOREN, S. E.; BUCHANANNE, G. D. A national evaluation of leaching potential of aldicarb - Part 1: An integrated assessment methodology. Ground Water Monitoring \& Remediation, v.9(4), p.109-125, 1989.

MARQUES, M. N.; COTRIM, M. B.; PIRES, M. A. F. Avaliação do impacto da agricultura em áreas de proteção ambiental, pertencentes à bacia hidrográfica do Rio Ribeira de Iguape, São Paulo. Química Nova, v.30(5), p.1171-1178, 2007.

MARTINS, M.E.; BOTTA, C.M.R.; NUNES, M.E.T.; BARBOSA, D.S.; DAMASCENO, L.H.S.; ZAIAT, M. Aplicação de bioensaios de toxicidade utilizando resazurina para avaliação da eficiência do reator anaeróbio horizontal de leito fixo na degradação do aldicarbe. In: SEMINÁRIO DO PROJETO TEMÁTICO FAPESP, 2., 2007, São Carlos. Anais... São Carlos: EESC/USP, 2007.

MILES, C.J.; DELFINO, J.J. Determination of aldicarb and its derivatives in groundwater by high-performance liquid chromatography with UV detection. Journal of Chromatography, v.299, p.275-280, 1984.

MILES, C. J.; DELFINO, J. J. Fate of aldicarbe, aldicarbe sulfoxide and aldicarbe sulfone in Floridian groundwater. Journal of Agricultural and Food Chemistry, v.33, p.455-460, 1985.

MONOD, J. Recherches sur la Croissance des Cultures Bacteriennes. Hermann \& Cie, 1942, 210p.

MOYE, H. A.; MILES, C. J. Aldicarb contamination of groundwater. Review of Environmental Contamination and Toxicology, v.105, p.99-146, 1989.

MUNCH, J. W.; Method 531.1 Measurement of n-methylcarbamoyloximes and nmethylcabamates in water by direct aqueous injection HPLC with post column derivatization (Revision 3.1). EPA: Cincinnati, 1995.

MUYZER, G.; WALL, E.C.; UITTERLINDEN, G. Profiling of complex microbial 
populations by denaturing gradient gel electrophoresis analysis of polymerase chain reaction amplified genes coding for 16S RNAr. Applied Environmental Microbiology, v.59(3), p.695-700, 1993.

NELSON,D.M.; OHENE-ADJEI, S.; HU, F.S.; CANN, I.K.; MACKIE, R.I. Bacterial diversity and distribution in the holocene sediments of a northern temperate lake. Microbial Ecology, v.54 (2), p.252-263, 2007.

NIELSEN, A.T.; LIU, W.T.; FILIPE, C.; GRADY JR, L.; MOLIN, S.; STAHL, D.A. Identification of a novel group of bacteria in sludge from a deteriorated biological phosphorus removal reactor. Applied and Environmental Microbiology, v.65, p.1251-1258, 1999.

NUNES, G. S.; ALONSO, R. M.; RIBEIRO, M. L.; BARCELÓ Determination of aldicarb, aldicarb sulfoxide and aldicarb sulfone in some fruits and vegetables using high-performance liquide chromatography-atmospheric pressure chemical ionization mass spectrometry. Journal of Chromatography A, v.888, p.113-120, 2000.

OREMLAND, R.S.; MARSH, L.; POLCIM, S. Methane production and simultaneous sulphate reduction in anoxic, salt marsh sediments. Nature, v.296, p.143-145, 1982.

OU, L. T.; EDVARDSSON, K. S. V.; RAO, P. S. C. Aerobic and anaerobic degradation of aldicarb in soils. Journal of Agricultural and Food Chemistry, v.33, p.72-78, 1985a.

OU, L. T.; EDVARDSSON, K. S. V.; THOMAS, J. E.; RAO, P. S. C. Aerobic and anaerobic degradation of aldicarb sulfone in soils. Journal of Agricultural and Food Chemistry, v.33, p.545-548, 1985b.

PERRY, R. H.; GREEN, D. W. Perry's Chemical engineers' handbook, 7th ed. McGrawHill, 1997. 2640 p.

PIFFER, R.; RIGITANO, R. L. O. Lixiviação e degradação do inseticida aldicarbe em dois diferentes solos. Ciência e Prática, v.15(4), p.355-363, 1991.

POSTGATE, J.R. The sulfate-reducing bacteria. 2a ed. Cambridge University Press, 1984. 
RIBEIRO, R. Influência do tipo de substrato na dinâmica de formação do biofilme em matrizes de poliuretano. 2001. 193 f. Dissertação (Mestrado em Hidráulica e Saneamento) Escola de Engenharia de São Carlos, Universidade de São Paulo, São Carlos, 2001.

RIBEIRO, R. Recuperação de águas contaminadas com gasolina utilizando reatores de leito fixo. 2005. 150 f. Tese (Doutorado em Hidráulica e Saneamento) - Escola de Engenharia de São Carlos, Universidade de São Paulo, São Carlos, 2005.

RICKARD, R.W.; DOROUGH, H.W. In vivo formation of nitrosocarbamates in the stomach of rats and guinea pigs. Journal of Toxicology and Environmental Health, v.14, p.279-290, 1984.

RIGITANO, R. L. O.; GOUVÊA, A. V. Contaminação de manancial hídrico com resíduos de inseticida em Maria da Fé - MG. In: CONGRESSO BRASILEIRO DE ENTOMOLOGIA, 15., 1995, Caxambu. Resumos... Lavras: SEB/UFLA, 1995. p.485.

RIPLEY, L.E.; BOYLE, W.C.; CONVERSE, J.C. Improved alkalimetric monitoring anaerobic digestion of high-strenght wastes. Journal of Water Pollution Control Federation, v.58, p.406-411, 1986.

ROSE, M.T.; SANCHEZ-BAYO, F.; CROSSAN, A.N.; KENNEDY, I.R. Pesticide removal from cotton farm tailwater by a pilot-scale ponded wetland. Chemosphere, v.63, p.1849-1858, 2006.

SILVA, A.J.; HIRASAWA, J.S.; VARESCHE, M.B.; FORESTI, E.; ZAIAT, M. Evaluation of support materials for the immobilization of sulfate-reducing bacteria and methanogenic archaea. Anaerobe, v.12(2), p.93-98, 2005.

SMELT, J. H.; VAN DE PEPPEL-GROEN, A. E.; VAN DER PAS, L. J. T.; DIJKSTERHUIS, A. Development and duration of accelerated degradation of nematicides in different soils. Soil Biology \& Biochemistry, v.28(12), p.1757-1765, 1996.

SMITH, N.R.; YU, Z.; MOHN, W.W. Stability of the bacterial community in a pulp mill 
effluent treatment system during normal operation and a system shutdown. Water Research, v.37(20), p.4873-4884, 2003.

SORENSEN, K.B.; GLAZER, B.; HANNIDES, A.; GAIDOS, E. Vertical and horizontal structure of the microbial community in sandy carbonate sediment. Não publicado.

STROSSER, P.; PAU VALL, M.; PLÖTSCHER, E. Water and agriculture: contribution to an analysis of a critical but difficult relationship. Disponível em: <http://europa.eu.int/comm/agriculture/envir/report/en/eau_en/report.htm>. Acesso em: 15 out. 2008.

TAMURA, K.; DUDLEY, J.; NEI, M.; KUMAR, S. MEGA 4: Molecular Evolution Genetics Analysis (MEGA) Software Version 4.0. Molecular Biology and Evolution, v.24(8), p.1596-1599, 2007.

TRINGE, S.G.; VON MERING, C.; KOBAYASHI, A.; SALAMOV, A.A.; CHEN, K.; CHANG, H.W.; PODAR, M.; SHORT, J.M.; MATHUR, E.J.; DETTER, J.C.; BORK, P.; HUGENHOLTZ, P.; RUBIN, E.M. Comparative metagenomics of microbial communities. Science, v. 308(5721), p.554-557, 2005.

van HOUTEN, R.T. Biological sulphate removal with synthesis gas. 1996. 125 f. Tese (PhD) - Wageningen Agricultural University, Wageningen, Holanda, 1996.

UETA, J.; PEREIRA, N. L.; SHUHAMA, I. K.; CERDEIRA, A. L. Biodegradação de herbicidas e biorremediação. Biotecnologia, Ciência \& Desenvolvimento, v.10, p.10-13, 1999.

UNION CARBIDE. Union Carbide agricultural products. Temik® aldicarbe pesticide. Removal of residues from water. Research and Development Department, 1979.

USEPA. Pesticides in groundwater. Data base 1988 interim report. Washington, DC, US Environmental Protection Agency, Office of Pesticide Programs, Environmental Fate and Groundwater Branch, 1988. 
VALINSKY, L.; VEDOVA, G.D.; SCUPHAM, A.J.; ALVEY, S.; FIGUEROA, A.; YIN, B.; HARTIN, R.J.; CHROBAK, M.; CROWLEY, D.E.; JIANG, T.; BORNEMAN, J. Analysis of bacterial community composition by oligonucleotide fingerprinting of rRNA genes. Applied and Environmental Microbiology, v.68(7), p.3243-3250, 2002.

VIEIRA, L.G.T. Estimativa de parametros cineticos intrínsecos de utilização de substrato por lodo imobilizado. 1996. 63 f. Dissertação (Mestrado em Hidráulica e Saneamento) Escola de Engenharia de São Carlos, Universidade de São Paulo, São Carlos, 1996.

VINK, J.P.M.; VAN DER ZEE, S.E.A.T.M. Effect of oxygen status on pesticide transformation and sorption in undisturbed soil and lake sediment. Environmental Toxicology and Chemistry, v.16(4), p.608-616, 1997.

WHO. Aldicarb: health and safety guide. Geneva: World Health Organization, 1991, 28p;

WOLIN, E.A.; WOLIN, M.J.; WOLFE, R.S. Formation of methane by bacterial extracts. The Journal of Biological Chemistry, v.238, p.2882-2886, 1963.

XAVIER, F.G. Intoxicação por aldicarb (“chumbinho”) em cães e gatos: estudo das alterações post mortem macroscópicas e diagnóstico toxicológico por meio da cromatografia em camada delgada em amostras de conteúdo estomacal. 2004. $191 \mathrm{f}$. Dissertação (Mestrado em Patologia Experimental e Comparada) - Faculdade de Medicina Veterinária e Zootecnia, Universidade de São Paulo, São Paulo, 2004.

ZAIAT, M. Desenvolvimento de reator anaeróbio horizontal de leito fixo (RAHLF) para tratamento de águas residuárias. 1996. 157 f. Tese (Doutorado em Hidráulica e Saneamento) - Escola de Engenharia de São Carlos, Universidade de São Paulo, São Carlos, 1996.

ZAIAT, M.; CABRAL, A.K.A.; FORESTI, E. Horizontal-flow anaerobic immobilized sludge reactor for wastewater treatment: Conception and performance evaluation. Revista Brasileira de Engenharia - Caderno de Engenharia Química, v.11, p.33-42, 1994. 
carbamate pesticides in water by capillary gas chromatography. Journal of Chromatography, v.299, p.269-274. 